UNIVERSIDADE DE SÃO PAULO

FACULDADE DE FILOSOFIA, LETRAS E CIÊNCIAS HUMANAS

CRISTIANE FIGUEIREDO FLORENCIO

"Literapalco" em Lygia Bojunga: arte como projeto de vida

VERSÃO CORRIGIDA

SÃO PAULO 


\title{
"Literapalco" em Lygia Bojunga: arte como projeto de vida
}

\author{
VERSÃO CORRIGIDA
}

Tese apresentada ao Departamento de Letras Clássicas e Vernáculas da Faculdade de Filosofia, Letras e Ciências Humanas da Universidade de São Paulo para obtenção do título de Doutora em Letras.

Área de Concentração: Estudos Comparados de Literaturas de Língua Portuguesa

Orientadora: Profa. Dra. Maria dos Prazeres Santos Mendes 
Autorizo a reprodução e a divulgação total ou parcial deste trabalho por qualquer meio convencional ou eletrônico para fins de estudo e pesquisa, desde que citada a fonte.

Catalogação na Publicação

Serviço de Biblioteca e Documentação

Faculdade de Filosofia, Letras e Ciências Humanas da Universidade de São Paulo

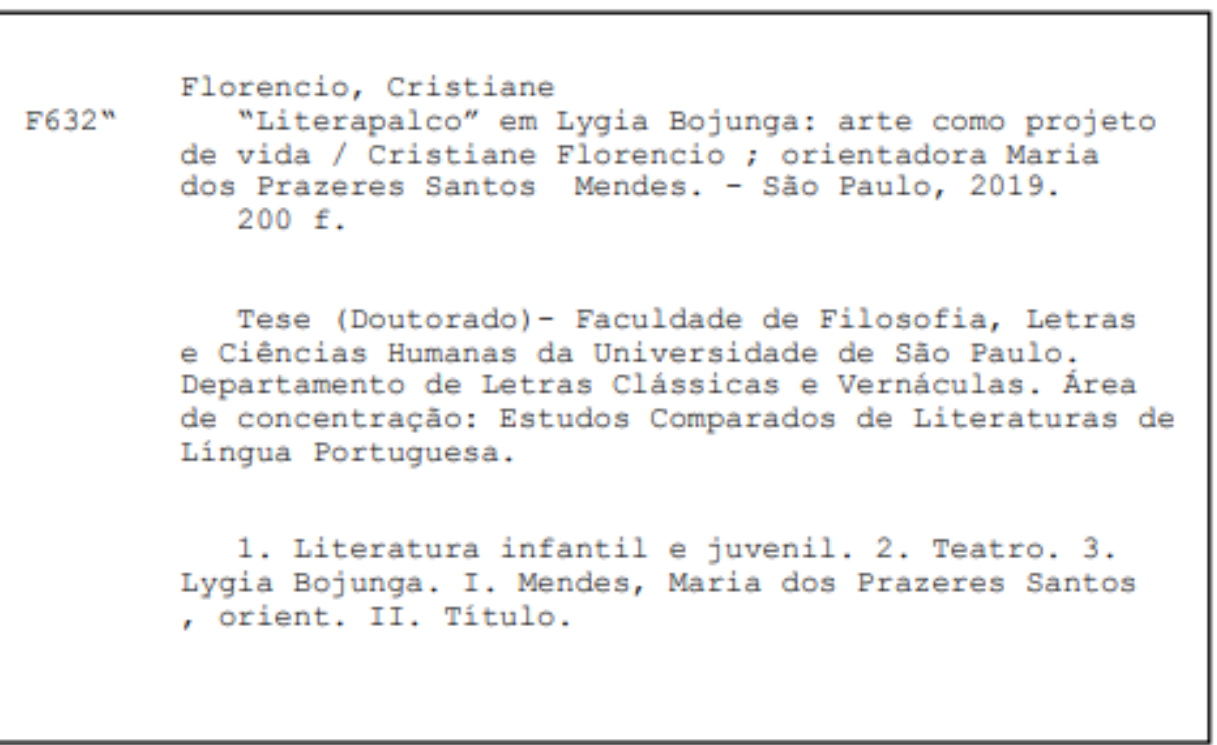




\section{ENTREGA DO EXEMPLAR CORRIGIDO DA DISSERTACÃO/TESE}

Termo de Ciência e Concordância do (a) orientador (a)

Nome do (a) aluno (a): Cristiane Figueiredo Florêncio

Data da defesa: $23 / 10 / 2019$

Nome do Prof. (a) orientador (a): Maria dos Prazeres Santos Mendes

Nos termos da legislação vigente, declaro ESTAR CIENTE do conteúdo deste EXEMPLAR CORRIGIDO elaborado em atenção às sugestões dos membros da comissão Julgadora na sessão de defesa do trabalho, manifestando-me plenamente favorável ao seu encaminhamento e publicação no Portal Digital de Teses da USP.

São Paulo, 02/02/2020 
Nome: FLORENCIO, Cristiane Figueiredo

Título: "Literapalco" em Lygia Bojunga: arte como projeto de vida

Tese apresentada ao Departamento de Letras Clássicas e Vernáculas da Faculdade de Filosofia, Letras e Ciências Humanas da Universidade de São Paulo para obtenção do título de Doutora em Letras.

Aprovada em: 23/10/2019

\section{Banca Examinadora}

Prof $^{\mathrm{a}} \mathrm{Dr}^{\mathrm{a}} \quad$ Maria José Pereira Gordo Palo

Instituição: PUC-SP

Julgamento: Aprovada

Prof ${ }^{\mathrm{a}}$. Dra ${ }^{\mathrm{a}}$ Maria Zilda da Cunha

Instituição: FFLCH USP

Julgamento: Aprovada

Prof $^{\mathrm{a}} \mathrm{Dr}^{\mathrm{a}} \quad$ Sandra Trabucco Velenzuela

Instituição: Fatec

Julgamento: Aprovada 
À autora Lygia Bojunga, que me leva, constantemente, à Terra do Nunca.

Aos músicos Isaac, Taylor e Zachary, que me fizeram amar ainda mais a música.

À minha avó Felícia, que é a minha eterna artista épica. 


\section{AGRADECIMENTOS}

$\grave{A}$ artista Lygia Bojunga, quem me proporcionou esse grande estudo em teatro e literatura.

À minha querida orientadora, $\operatorname{prof}^{\mathrm{a}} \operatorname{Dr}^{\mathrm{a}}$ Maria dos Prazeres Santos Mendes, quem me ajudou infinita e pacientemente nesse processo importante de minha carreira acadêmica.

À minha querida professora $\operatorname{Dr}^{\mathrm{a}}$ Maria Zilda da Cunha, quem me incentivou e acreditou no meu trabalho em diversos momentos.

Ao professor Dr. José Nicolau Gregorin, quem tornou possível o início dessa nova etapa acadêmica.

À professora Dr ${ }^{\mathrm{a}}$ Cláudia Riolfi, quem, de fato, me apresentou à autora Lygia Bojunga.

Às professoras Dr ${ }^{\mathrm{a}}$ Deusa Maria Souza Pinheiro-Passos, Dr ${ }^{\mathrm{a}}$ Marília Mendes Ferreira e ao professor Dr. Marcos César de Paula Soares, que foram os únicos, durante todo o processo de graduação, a reconhecerem explicitamente o meu (des) empenho acadêmico, o que me auxiliou a concluir o bacharelado e a licenciatura na língua inglesa.

À Escola de Aplicação da Faculdade de Educação da USP, cujo modelo educacional me levou a fazer pós-graduação, com o sonho de lecionar em uma instituição como esta.

A todos os professores, coordenadores, diretores e demais funcionários que trabalharam em minha antiga escola e contribuíram com a minha formação preparatória para o ensino superior.

A todos os meus ex-professores de cursinho pré-vestibular.

À professora de espanhol Ivonne Alpizar Delgado, sem a qual eu jamais teria conseguido ingressar no doutorado direto. ;Gracias por aceptar el gran desafio!

Ao Matheus e à Cibelle, que me ajudaram em uma etapa final de urgência.

À bibliotecária da FFLCH, Elizabeth B. Santos, por ter sido tão solícita comigo.

Aos meus pais, que nunca me desviaram do caminho do estudo.

Aos familiares distantes que sempre acreditaram em mim.

Aos familiares que desacreditaram e anteciparam Que horas ela volta?

A Marcos Vinícius Jacinto, que, mesmo não estando mais presente, fez parte desse processo, auxiliando-me e estando presente nos momentos difíceis de decisão.

À minha amiga - daquelas que Carolina e Nicolina nenhuma botariam defeito - Mariana Sanae, que acompanhou vários processos de transformação em minha vida.

Ao Bruno Giuntini Iunes, por ser tudo o que a vida poderia ter sido e não foi: obrigada pelo imenso apoio e pela compreensão.

Às minhas eternas super-heroínas, minhas avós, Maria e Felícia.

Aos meus (ex e futuros) alunos, que são o motivo real do início de toda essa trajetória acadêmica. 


\section{RESUMO}

\section{FLORENCIO, Cristiane Figueiredo. "Literapalco" em Lygia Bojunga: arte como projeto}

de vida. 2019. 200f. Tese (Doutorado em Letras) - Faculdade de Filosofia, Letras e Ciências Humanas, Universidade de São Paulo, São Paulo, 2019.

A literatura de Lygia Bojunga tem como uma de suas características marcantes a teatralidade. Propõe-se, neste trabalho, a analisar a maneira pela qual essa teatralidade é construída verbalmente, a fim de demonstrar os efeitos oriundos dessa conjugação entre literatura e teatro, em todas as obras da autora. Para essa análise, aplica-se uma metodologia empírica - analítica, que se dispõe a investigar, na obra da autora, as estratégias literárias recorrentes que coincidem com recursos do teatro, com base em estudos de autoridades da arte teatral, tais como Patrice Pavis, Jean-Jacques Roubine, Anne Ubersfeld, Gerd Bornheim, Raymond Williams, Bertolt Brecht, Erwin Piscator, Ana Maria de Amaral, Valmor Beltrane, Margot Berthold, Felisberto Costa, Admar Costa, Iná Costa, Sílvia Fernades e J. Guinsburg, Marli Terezinha Furtado, Lionel Abel, Sonia Aparecida Vido Pascolati e Igor de Almeida Silva. Constatou-se que os recursos teatrais mais recorrentes na literatura de Lygia Bojunga pertencem ao Teatro Épico, ao Teatro Mambembe, ao Teatro de Animação e ao Metateatro. Os efeitos analisados são a construção da visualidade e da expressividade dos elementos contidos na caixa cênica, que se materializam literariamente, e a fusão entre o projeto literário da autora e o seu projeto de vida.

Palavras-chave: Lygia Bojunga. Literatura. Teatro. 


\begin{abstract}
FLORENCIO, Cristiane Figueiredo. "The literary theater stage" in Lygia Bojunga's work: art as a life project. 2019. 200f. Tese (Doutorado em Letras) - Faculdade de Filosofia, Letras e Ciências Humanas,Universidade de São Paulo, São Paulo, 2019.

Lygia Bojunga's literature has the theatricality as one of its remarkable features. This study is aimed at analyzing the means by which the above-mentioned theatricality is verbally framed, in order to evince the effects deriving from the conflation between literature and drama in the author's complete work. In doing so, the empirical-analytical methodology applies intended to investigate recurring literary strategies that correspond with drama resources in Bojunga's work, based on studies by some of the theatrical art authorities, such as Patrice Pavis, Jean-Jacques Roubine, Anne Ubersfeld, Gerd Bornheim, Raymond Williams, Bertolt Brecht, Erwin Piscator, Ana Maria de Amaral, Valmor Beltrane, Margot Berthold, Felisberto Costa, Admar Costa, Iná Costa, Sílvia Fernades e J. Guinsburg, Marli Terezinha Furtado, Lionel Abel, Sonia Aparecida Vido Pascolati, and Igor de Almeida Silva. Thus, the most recurrent theatrical resources in Lygia Bonjunga's literature were found to belong to the Epic Theater, the Mambembe Theater, the Animation Theater, and the Metatheater. In this meaning, the analyzed effects are the construction of visuality and expressiveness of the elements found in the theatrical stage, which materialize in a literary way, as well as the fusion between the author's literary project and her own life project.
\end{abstract}

Key words: Lygia Bojunga. Literature. Theater 


\section{SUMÁRIO}

1 INTRODUÇÃ̃ ............................................................................................................................... 12

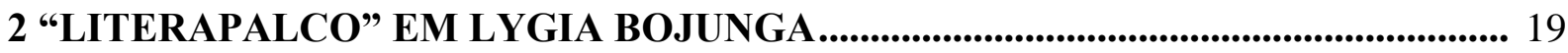

2.1. O TEATRO NA LITERATURA DE LYGIA BOJUNGA …........................................ 19

2.2. A TEATRALIDADE NA CONSTRUÇÃO IMAGÉTICA NA LITERATURA DE

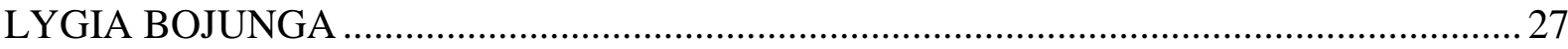

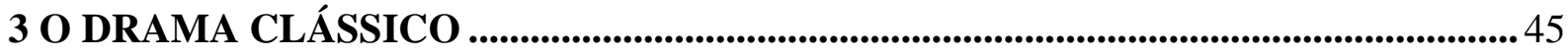

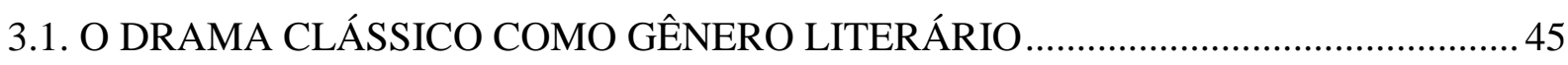

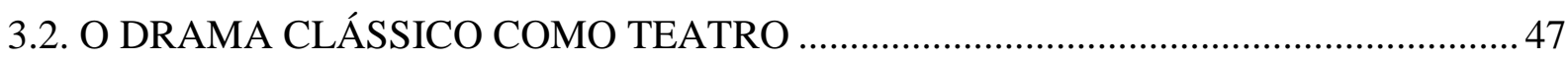

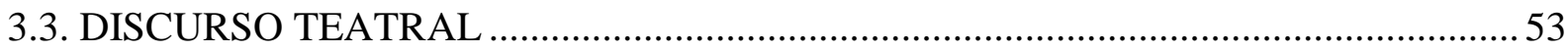

3.3.1. Diálogos ........................................................................................................................................... 54

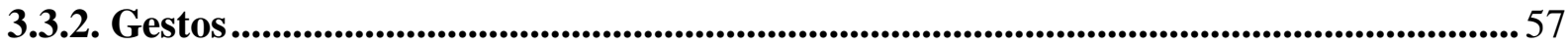

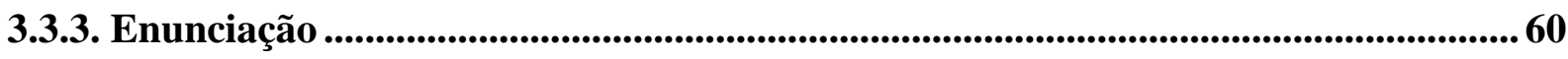

4 TEATRO ÉPICO.............................................................................................................. 63

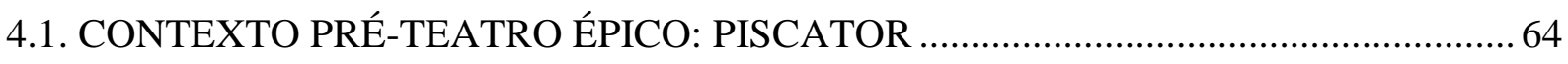

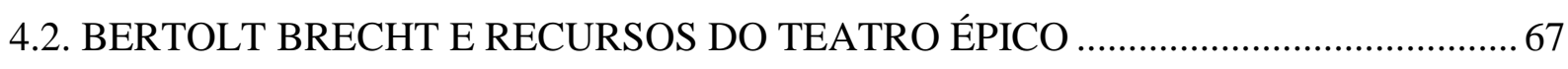

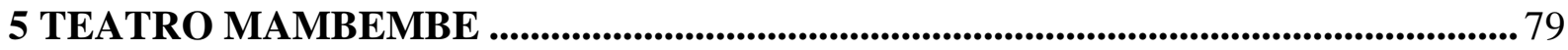

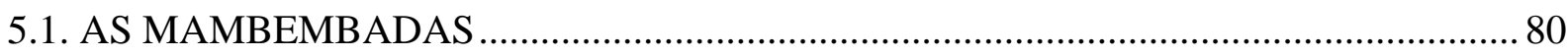

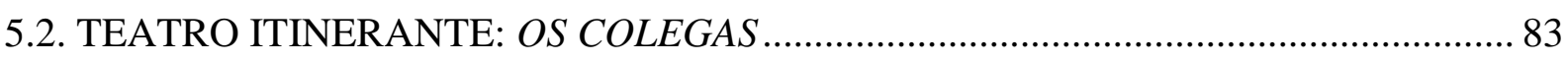

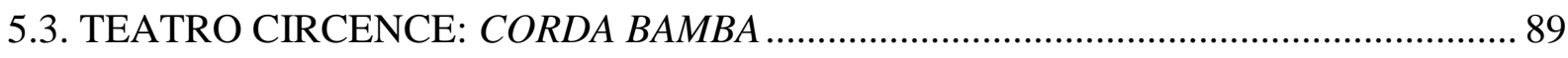

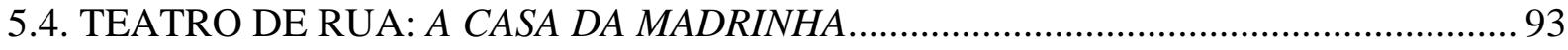

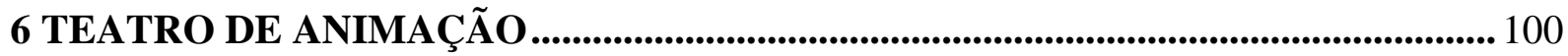

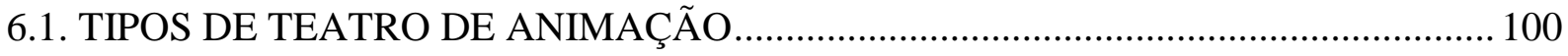

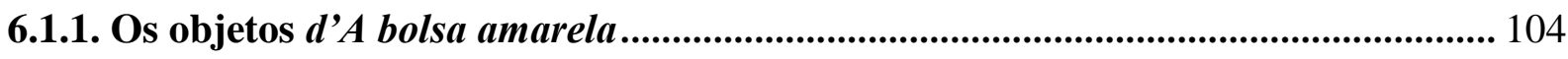

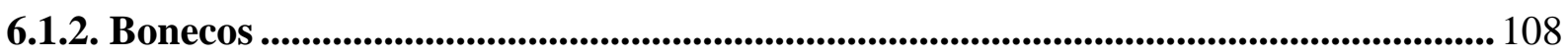

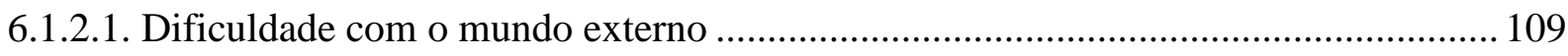

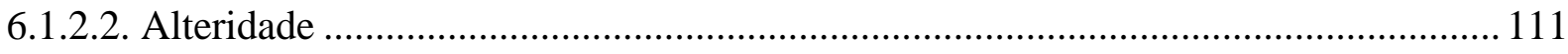

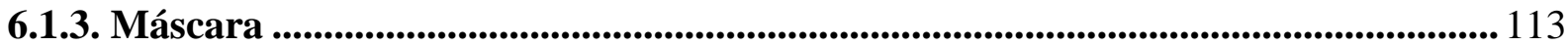




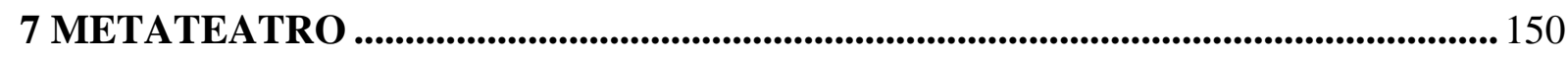

7.1. METAlinguAgEM, METATEATRO, TEATRO DENTRO DO TEATRO E

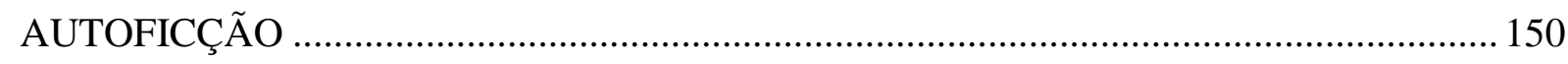

7.2. METATEATRO E TEATRO DENTRO DO TEATRO: ANGÉLICA............................. 153

7.3.DO CUMPRIMENTO DA TRILOGIA LITERÁRIA AO CUMPRIMENTO DE UM

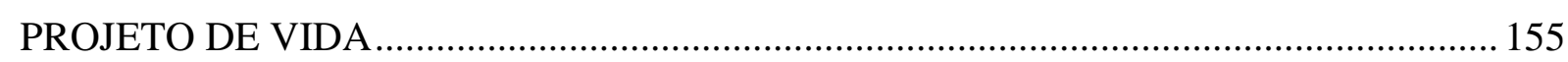

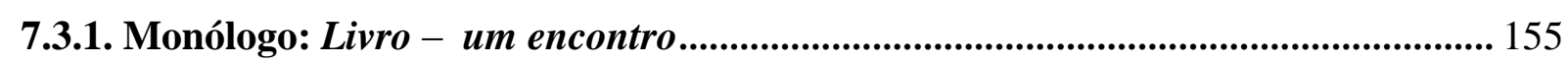

7.3.2. Fazendo Ana Paz: criando a consciência dramática da personagem..................... 159

7.3.3. Teatro Dentro do Teatro: espelhamento em Paisagem ............................................ 164

7.3.4. Intramuros: a trilogia literária inversa e a autorreferência.................................... 173

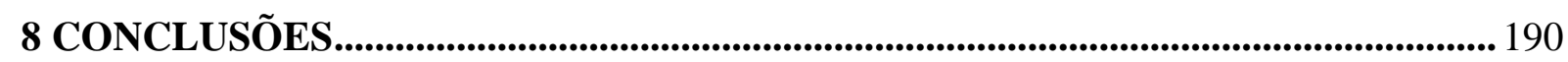

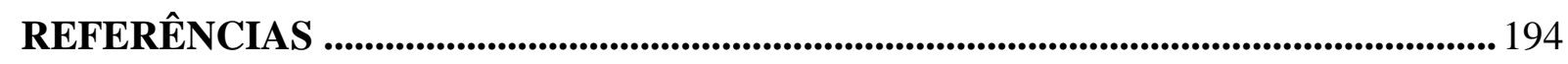


Vocês, artistas que fazem teatro

Em grandes casas, sob sóis artificiais

Diante da multidão calada, procurem de vez em quando O teatro que é encenado na rua.

Cotidiano, vário e anônimo, mas

Tão vívido, terreno, nutrido da convivência

Dos homens, o teatro que se passa na rua.

Bertolt Brecht

A vida é uma peça de teatro que não permite ensaios. Por isso, cante, chore, dance, ria e viva intensamente, antes que a cortina se feche e a peça termine sem aplausos.

Charles Chaplin

O amor e a literatura coincidem na procura apaixonada, quase sempre desesperada, da comunicação.

Jorge Duran

Uma obra de arte é boa quando surge de uma necessidade. É no modo como ela se origina que se encontra seu valor, não há nenhum outro critério.

Rainer Maria Rilke

Só o amor e a arte tornam a existência tolerável.

W. Somerset Maugham 


\section{INTRODUÇÃO}

Lygia Bojunga, escritora de literatura infantil e juvenil, destaca-se das demais, pois apresenta uma literatura única, seja pelas estratégias literárias empregadas, seja pelas temáticas abordadas em suas obras. A autora sabe dar expressão ao imaginário infantil e juvenil ao mesmo tempo em que trata de dilemas e de assuntos da infância e da adolescência de diferentes classes sociais, assuntos esses muitas vezes pouco explorados. Além disso, Bojunga retrata o processo de criação artística por meio da literatura de maneira complexa e poética. Como resultado desse trabalho, a escritora recebeu prêmios importantes, como a medalha Hans Christian Andersen em 1982 e o prêmio ALMA (Astrid Lindgren Memorial Award) em 2004.

Nota-se, em suas primeiras obras, que o universo lúdico é predominante. Já o universo realista é mais comum em algumas de suas últimas obras; entretanto, como os assuntos ligados a problemas sociais bem como o universo do imaginário permeiam a obra toda da autora, mesmo que de maneiras variadas, não será realizada tal distinção como forma de classificar a obra da autora em fases. Porém, como essas diferenças serão mencionadas em algumas partes deste trabalho, é importante salientar que o objetivo de suas referências está relacionado à tetralidade da literatura da autora, que é a base da análise desta tese, não a classificações de supostas fases a fim de comprovar mudanças literárias na obra da escritora.

Nesse sentido, visto que muito foi estudado acerca do universo lúdico, do fantástico, do maravilhoso na literatura de Lygia Bojunga, bem como a obra da autora já foi bastante analisada da perspectiva social, cabe ao presente trabalho inovar, sem negar as influências dessas abordagens; porém, não as tomando como referencial da análise.

Para isso, o presente trabalho propõe-se a analisar a literatura de Lygia Bojunga a partir, primordialmente, dos recursos do teatro mais recorrentes em suas obras e, como resultado disso, analisar, também, os efeitos que esses recursos proporcionam à sua obra, tais como a convergência existente entre um projeto de vida e um projeto literário e a convergência de recursos de outras artes - como a pintura, o cinema, a dança, a música e a fotografia - que auxiliam a estruturação dos recursos do teatro utilizados na literatura da autora. Outro efeito é a maior expressividade dada aos assuntos que as obras abordam, já que a escolha por determinados recursos teatrais, não apenas tornam as cenas mais vívidas, como também correspondem de modo mais artístico à temática tratada por Bojunga. 
Nesse sentido, buscou-se identificar na literatura de Lygia Bojunga os diferentes tipos de recursos teatrais que promovem todos esses efeitos: a construção da caixa cênica envolvendo, portanto, cenário, cenas, formas de iluminação, personagens, entre outros elementos teatrais -, o discurso teatral e os recursos do Teatro Clássico, do Épico, do Mambembe, do Animado e do Metateatro.

No que concerne à arte como projeto de vida da autora, explorou-se a relação existente entre o projeto literário de Ligya Bojunga, formado a partir de sua trilogia - Livro um encontro, Fazendo Ana Paz e Paisagem -, e a obra Intramuros, que, por si só, expõe a trajetória inversa à da trilogia. Dessa forma, esta obra une o eu-escritora da autora ao seu euleitora, ampliando recursos antes já utilizados, como referências a outras de suas obras e recuperação de suas memórias, o que permite uma reflexão acerca do legado que sua literatura já transmite.

A metodologia utilizada nesta tese baseou-se, de modo empírico, primordialmente na literatura de Lygia Bojunga, visto que foi a partir de leituras e releituras da obra da autora que foi possível identificar quais são os recursos teatrais mais recorrentes. A partir dessa compreensão, pautou-se em estudos sobre teatro de Patrice Pavis, como ponto de partida para análises mais desenvolvidas, a partir do conhecimento sobre diferentes tipos de teatro, o que auxiliou bastante a procura por bibliografia na biblioteca da Escola de Comunicação e Artes da USP, onde se pôde ter contato com bibliografia específica acerca de outras artes que dialogam com o teatro. Nesse sentido, ampliou-se o número de estudiosos acerca da arte teatral, entre eles estão: Patrice Pavis, Jean-Jacques Roubine, Anne Ubersfeld, Gerd Bornheim, Raymond Williams, Bertolt Brecht, Erwin Piscator, Ana Maria de Amaral, Valmor Beltrane, Margot Berthold, Felisberto Costa, Admar Costa, Iná Costa, Sílvia Fernades e J. Guinsburg, Marli Terezinha Furtado, Lionel Abel, Sonia Aparecida Vido Pascolati, Igor de Almeida Silva.

Utilizou-se, também, referências bibliográficas indicadas no curso de graduação, como Anatol Rosenfeld, e de pós-graduação, além de pesquisas em teatro que convergiram para o presente estudo.

Ademais, foi de extrema importância utilizar, também, as obras da autora, a fim de se compreender como o seu projeto de vida coincide com o seu projeto de arte, já que a sua última obra publicada até o presente momento, Intramuros, levantou, já em sua contracapa, um novo desafio ao presente trabalho, que já estava em processo de desenvolvimento: 
“[Intramuros] não é uma obra voltada para leitores mirins, e sim para quem se interessa pelo fazer literário e pelo cumprimento de um projeto de vida." "A partir dessa ideia, então, passouse a considerar Intramuros a obra de encerramento desta análise, visto que ela é considerada pela própria autora uma obra que está em outro nível de compreensão, justamente por aliar o processo de criação literária ao projeto de vida da autora, que é nítido, na obra, não apenas por ter sido alcançado, mas também por ter se imbricado à literatura de Lygia Bojunga. Acrescenta-se a isso que Intramuros é uma escrita mista, apresentando nesta um formato de texto teatral, o mais explícito de toda a obra da autora e é, por isso, extremamente pertinente a ser incluído não só como corpus, mas também como parte da metodologia desta tese.

Como a base da análise deste trabalho será a relação entre a literatura de Lygia Bojunga e o teatro, cabe considerar que toda peça de teatro, se não for uma peça baseada em improviso, é, primeiramente, um texto verbal. Sendo assim, há textos, inclusive literários, com propriedades dramáticas, que, embora não sejam encenados, são teatrais. Sobre isso, já até se criou a expressão "teatro literário":

Pavis (1999), ao inquirir se a teatralidade é uma propriedade do texto dramático, coloca a questão em termos da polêmica texto versus espetáculo; haveria uma espécie de texto dramático que visa à cena e dela necessita para alcançar plenitude - por isso chamado de 'teatro puro' - em oposição a uma outra espécie de texto cuja organização prescinde da atualização cênica, nomeado, então, 'teatro literário'.2

Mesmo a maioria das obras de Bojunga não sendo escritas com a finalidade de serem encenadas, elas apresentam cenas extremamente teatrais, sobretudo porque revelam o processo de criação textual e constroem um espetáculo imaginário no momento da leitura:

Embora a teatralidade seja mais evidentemente uma propriedade da cena,
acreditamos que o texto seja também um espaço de sua construção, particularmente
ao trabalharmos com a hipótese de que o metateatro revela os bastidores da
construção do texto e do espetáculo. Para constatar a pertinência dessa abordagem,
basta verificar como os signos teatrais disseminados no texto trazem uma
teatralidade latente a partir da qual o receptor é convidado a construir mentalmente o
espetáculo; mais do que isso, é instado a perceber a arte dramática como convenção,
acordo necessário entre autor e platéia para que o prazer do jogo teatral seja
possível. ${ }^{3}$

Tendo em vista esses aspectos, os objetos da presente análise são constituídos de toda a obra da autora - com exceção de Dos Vinte I, por se tratar de um copilado de trechos

\footnotetext{
${ }^{1}$ BOJUNGA, Lygia. Intramuros. 1. ed. Rio de Janeiro: Casa Lygia Bojunga, 2016.

${ }^{2}$ PAVIS, Patrice. Dicionário de teatro. São Paulo: Perspectiva, 2015, p.373.

${ }^{3}$ XI Congresso Insternacional da Abralic Tessituras, Interaçõess, Convergências, 2008, São Paulo, Brasil Metateatro: inscrição do espetáculo no textodramático... São Paulo: USP, p.4.
} 
de outras obras -, que, até o fim do primeiro semestre de 2019, somam o total de 23 obras. São elas: Os colegas (1972), Angélica (1975), A bolsa amarela (1976), A casa da madrinha (1978), Corda bamba (1979), O sofá estampado (1980), Tchau (1984), O meu Amigo Pintor (1987), Nós três (1987), Livro - um encontro (1988), Fazendo Ana Paz (1991), Paisagem (1992), Seis vezes Lucas (1995), O abraço (1995), Feito à mão (1996), A cama (1996), O Rio e eu (1999), Retratos de Carolina (2002), Aula de inglês (2006), Sapato de salto (2006), Dos Vinte I (2007), Querida (2009), Intramuros (2016).

Dessa maneira, no primeiro capítulo, “Literapalco” em Lygia Bojunga, pretende-se mostrar a relação existente entre a literatura da autora e o teatro. Para isso, em um primeiro momento, em $O$ teatro na literatura de Lygia Bojunga, apresenta-se a definição de teatro com a qual a presente tese trabalha, que é uma definição norteada pela visualidade da arte teatral. A partir disso, há a menção ao processo solitário e imaginário de criação literária que coloca a autora em papéis teatrais, além de ser apresentado um panorama de sua obra, em que são demonstrados tanto alguns dos recursos mais básicos do teatro utilizados em sua literatura, quanto algumas das referências explícitas a essa arte. Nesse contexto, a importância do diálogo como uma de suas características literárias e teatrais é introduzida na análise.

Em um segundo momento, em A teatralidade na construção imagética na literatura de Lygia Bojunga, o modo como a visualidade teatral é reproduzida verbalmente na literatura é explorado com base nos recursos das artes audiovisuais: cinema, música, pintura, dança e fotografia.

Tendo abordado a literatura e o teatro em Lygia Bojunga, passa-se ao segundo capítulo, sobre o drama clássico, que discorre sobre a teoria dos gêneros literários - e que trata sobre o Teatro Clássico. Expõe-se a teoria clássica de pureza dos gêneros para negar sua total aplicação às obras de Bojunga, já que a literatura da autora segue mais a teoria moderna, de mescla de gêneros. Acerca do Teatro Clássico, trabalham-se as regras aristotélicas de verossimilhança da ação e do tempo. Essas duas regras são aplicadas a trechos de obras da autora, como forma de explicitar a importância da ação para a coerência narrativa e como forma de mostrar o nível de importância do transcorrer do tempo nos padrões aristotélicos nas obras de Lygia Bojunga. A partir da relação entre ação e tempo, introduzem-se recursos contidos no discurso teatral, como diálogos, gestos e enunciação. 
No terceiro capítulo, acerca do Teatro Épico, define-se o termo épico em oposição à caracterização do Teatro Clássico. Contextualiza-se o surgimento do Teatro Épico - com Piscator e Brecht - com o objetivo de que se compreenda a grande importância social em que se baliza esse teatro político e a oposição que o Teatro Épico faz ao Teatro Dramático, visto que há uma conjuntura de crise do drama. Alguns dos recursos do Teatro Épico - como rompimento da ilusão teatral, distanciamento do público, processo de reflexão, ausência de preocupação com as regras aristotélicas, personagens marginalizadas - serão identificados em algumas obras de Bojunga, nesse caso, as de teor mais social, como Sapato de salto, Aula de inglês e Retratos de Carolina.

O Teatro Mambembe ocupa o quarto capítulo, em que se relaciona esse tipo de teatro ao Teatro Itinerante, como o Teatro Circense e o Teatro de Rua. A ênfase aqui é dada, tanto ao cunho popular, quanto ao móbil, dos recursos teatrais. Nesse sentido, há a exposição das menções ao Mambembe na obra da autora, incluindo o projeto As Mambembadas, que se iniciou com a escrita de uma obra que também foi encenada pela própria Lygia Bojunga. Além disso, é abordado o Teatro Itinerante, que, em Os colegas, aparece não apenas relacionado à temática, mas também a alguns recursos teatrais, como o desenvolvimento do improviso. Outrossim, em Corda bamba, parte da temática também é abordada de acordo com um tipo de Teatro Mambembe: o Teatro Circense. Por fim, o Teatro de Rua é tratado por meio de recursos teatrais, como a construção da figura do saltimbanco, na obra $A$ casa da madrinha.

No quinto capítulo, intitulado Teatro de Animação, definem-se os tipos de objetos e suas respectivas funções nesse teatro. Como os objetos relacionados ao teatro são parte de várias obras de Lygia Bojunga, esse capítulo se pauta em um número grande de análises de obras. Por essa razão, os temas destas também são levados em consideração, visto que proporcionam teatralidade às cenas. Nesse capítulo, também há a definição de Teatro das Sombras, uma vez que a sombra é outro recurso do Teatro de Animação. Esses recursos são impressos no registro verbal, acarretando a imagem da presença ou da ausência de iluminação nas cenas, o que se torna uma escolha literária que harmoniza muito bem com as temáticas retratadas na literatura de Lygia Bojunga.

Por fim, o sexto capítulo, sobre o Metateatro, relaciona a metalinguagem ao Metateatro. Nesse capítulo, a obra Angélica é analisada, para se distinguir o Metateatro do Teatro Dentro do Teatro. Outrossim, a trilogia, que se inicia com o projeto teatral As 
Mambembadas e tem como um de seus intuitos formar uma sequência literária que une o euleitora ao eu-escritora de Lygia Bojunga, é abordada de acordo com recursos do Metateatro, tais como a autoficção, a explicação do fazer teatral, o rompimento entre o palco e a plateia e a autorreferência. Em seguida, a análise metateatral de Intramuros encerra esta tese, ao comprovar que é uma obra que não apenas reúne temáticas e recursos teatrais e literários das obras anteriores da autora, como também faz o trajeto inverso ao da sequência literária estabelecida na trilogia mencionada. Esse trajeto inverso coloca o eu-leitora de Lygia Bojunga em convergência com seu eu-escritora, sendo este, por sua vez, o responsável pelo cumprimento tanto de seu projeto literário, quanto de seu projeto de vida. 
O mundo inteiro é um palco

E todos os homens e mulheres não passam de meros atores.

William Shakespeare

A arte não reproduz o que vemos. Ela nos faz ver.

Paul Klee

Toda a arte é uma forma de literatura, porque toda a arte é dizer qualquer coisa. Há duas formas de dizer - falar e estar calado. As artes que não são a literatura são as projecções de um silêncio expressivo. Há que procurar em toda a arte que não é a literatura a frase silenciosa que ela contém, ou o poema, ou o romance, ou o drama.

Álvaro de Campos

Ali estava a imagem criada pela mão de um pintor me revelando, em outra linguagem, o mesmo que a minha mão de escritora tinha procurado pintar nos meus contos. Por que então não me sentir tomada pela sensação de familiaridade se o pintor e eu falávamos de uma mesma sentença a ser cumprida: a solidão.

Lygia Bojunga 


\title{
2 “LITERAPALCO” EM LYGIA BOJUNGA
}

\subsection{O TEATRO NA LITERATURA DE LYGIA BOJUNGA}

O teatro tem sido uma das artes mais antigas da humanidade. Entretanto, a palavra "teatro" em si pode apresentar vários significados, dependendo da perspectiva adotada acerca do termo. Nesse sentido, o teatro pode ser um local, um texto, a representação deste, um gênero do drama, a obra de um artista. No Dicionário de Teatro, de Patrice Pavis, encontra-se um resumo da origem da teatralidade e do teatro que aponta para essa polissemia de significados:

\begin{abstract}
A origem grega da palavra teatro, o theatron, revela uma propriedade esquecida, porém fundamental, desta arte: é o local de onde o público olha uma ação que lhe é apresentada num outro lugar. O teatro é mesmo, na verdade, um ponto de vista sobre um acontecimento: um olhar, um ângulo de visão e raios ópticos o constituem. Tãosomente pelo deslocamento da relação entre olhar e objeto olhado é que ocorre a construção onde tem lugar a representação. Durante muito tempo, na língua clássica dos séculos XVII e XVIII, o teatro será também a cena propriamente dita. Por uma segunda translação metonímica, o teatro se torna enfim a arte, o gênero dramático (daí as interferências com a literatura, tão amiúde fatais à arte cênica), mas também a instituição (o Teatro-Francês) e finalmente o repertório e a obra de um autor (o teatro de Shakespeare). A finalização desse exílio do teatro desde o local do olhar se concretiza nas metáforas do mundo como teatro ou do sentido de lugar de ação, ou finalmente da atividade do histrião na vida de todo dia (fazer teatro ou - para atualizar o idiotismo - fazer cinema). ${ }^{4}$
\end{abstract}

Com tantas possibilidades de significados, é preciso deixar claro com qual se trabalha ao analisar obras literárias e, sobretudo, que a literatura e o teatro são artes distintas, porém que podem se mesclar, principalmente na literatura contemporânea em que os códigos dificilmente aparecem isolados.

Assim, ao longo da análise presente, o termo teatro, quando aplicado à obra de Lygia Bojunga, será utilizado, de modo mais geral, para referir-se à eficiência da visualidade que a literatura da autora proporciona, da mesma maneira que, no teatro, esse recurso é essencial. Além disso, o termo teatro leva em conta o contexto histórico em que os textos teatrais são escritos, por isso consideram-se também os assuntos abordados nesse tipo de texto. Portanto, a melhor definição a ser aplicada na presente análise é esta:

\footnotetext{
${ }^{4}$ PAVIS, Patrice. Dicionário de teatro. São Paulo: Perspectiva, 2015, p. 372.
} 
Em francês (e em português também), teatro guardou a ideia de uma arte visual, enquanto nenhum substantivo tomou o sentido do conceito do texto: o drama, diferentemente do alemão ou do inglês, não é o texto escrito, e, sim, uma forma histórica (o drama burguês ou lírico, o melodrama) ou a significação derivada de 'catástrofe' ('estranho drama'). ${ }^{5}$

Dessa forma, nota-se que, tanto o termo "teatro" quanto o "drama" não se restringem ao texto escrito. O primeiro, que é uma arte visual, pode ser encontrado em outras artes, tal qual a literatura, que, por meio de recursos literários, amplia a capacidade de visualidade da narrativa, mesmo que no campo da imaginação. O segundo está no campo histórico da forma, uma vez que esta é mutável de acordo com a cultura e o momento em que uma sociedade vive, por esse motivo existem vários tipos de teatro: clássico, burguês, naturalista, épico, entre outros. Tendo isso em vista, a literatura bojunguiana é constituída por elementos do teatro tanto no que tange aos recursos visuais, utilizados pela autora na escrita, quanto na mudança temática, que é percebida pela recorrência maior de recursos de um determinado tipo de teatro. A exemplo disso, podem-se citar as obras iniciais da autora - como A bolsa amarela ou Angélica -, em que assuntos, como a desigualdade de gênero, são sugeridos; porém só são explicitados em obras mais recentes, como Retratos de Carolina, o que torna estas mais inclinadas ao uso de recursos do Teatro Épico.

Essas considerações prévias sobre o teatro são indispensáveis para a presente análise literária e teatral das obras de Lygia Bojunga Nunes, considerando também o seu amor pelo teatro. Esse sentimento pode ser notado em uma entrevista com a autora: A televisão foi uma experiência interessante, mas que se estendeu durante algum
tempo pela necessidade que eu tinha do salário que vinha de lá. A televisão nunca
me fascinou. Vou agora concluindo que sou muito artesanal; é só me ver
ensanduichada de tecnologia que fico só um terço de mim (na melhor das hipóteses).
Teatro, não; foi [e é] uma paixão.

É importante mencionar esse trecho em que a autora afirma preferir o teatro à televisão, em virtude de sua habilidade manual. Na televisão, tudo é construído por outras pessoas, o ator só precisa representar o papel que lhe cabe; na literatura, com características teatrais, o autor constrói todo o espaço, o tempo, as personagens e as narrativas.

Sendo assim, ao mesmo tempo em que é escritora de literatura, Bojunga coloca-se, metaforicamente, como diretora e atriz das peças que escreve em suas obras. A função similar à de diretora aparece quando Bojunga escreve obras com características metalinguísticas, que

\footnotetext{
${ }^{5}$ PAVIS, Patrice. Dicionário de teatro. São Paulo: Perspectiva, 2015, p.373.

${ }^{6}$ In: SANDRONI, Laura. De Lobato a Bojunga: as reinações renovadas. Rio de Janeiro: Agir, 1987, p.169.
} 
contam ao leitor o processo de criação das personagens, como em Fazendo Ana Paz e em Intramuros. Ademais, Bojunga aborda vários recursos usados em um palco de teatro para construir a narrativa, como máscaras (como ocorre em $O$ abraço e em Seis vezes Lucas) e linguagem corporal (como acontece em Corda bamba - movimentos de espetáculos circenses, sobretudo o andar na corda bamba - e Sapato de salto - a dança que Tia Inês ensina para Sabrina e Andrea Doria).

Já a função de atriz surge em algumas obras quando Lygia Bojunga coloca-se como personagem da narrativa ou mesmo quando escreve obras para viajar pelo país encenando-as. A participação da autora enquanto ela mesma ocorre em:

*Paisagem - obra em que Lygia Bojunga é, supostamente, personagem em uma narrativa em que tem a ajuda de um leitor para a construção do livro. Embora personagemautora não tenha nome, apresenta características biográficas de Bojunga, tais como suas viagens entre Rio de Janeiro e Londres;

* O Rio e eu - obra em que a autora conta as suas experiências sobre morar ora no Rio de Janeiro, ora em Londres, narrativa essa que demonstra o amor dela pela cidade brasileira;

*Fazendo Ana Paz - narrativa em que a escritora é inserida no texto para contar o processo de construção da personagem Ana Paz. Embora a narradora, que é personagemautora, não tenha nome, a referência à construção de outra personagem de uma obra de Bojunga - a personagem Raquel -, torna possível a interpretação de que a personagem-autora em Fazendo Ana Paz seja Lygia Bojunga.

*Livro - um encontro - obra em que Lygia Bojunga conta a sua história com o livro, desde seu gosto pela leitura até a escrita dele;

*Feito à mão - narrativa em que a autora conta o seu interesse em ser escritora de literatura, a necessidade de criar um espaço físico onde possa trabalhar e as experiências culturais que enriqueceram a sua literatura.

Bojunga também é atriz porque, para fundar a própria editora, Casa Lygia Bojunga, ela considerou que tinha que realizar um projeto, chamado As Mambembadas, mas teria de fazê-lo não somente como escritora: 
Um dia eu concluí que o projeto Casa Lygia Bojunga tinha que ser feito a três (eus): escritora, atriz e andarilha. Peguei meu livro Fazendo Ana Paz e comecei a trabalhar uma maneira de contar aquela história no palco. [...]

Foram quatro até agora as minhas Mambembadas Brasileiras: De Passo Fundo, lá no Rio Grande do Sul, até Belém do Pará, já nem sei em quantos espaços desenrolei meus tapetes (grande, pequeno, imenso, desse tamanhinho), centro cultural, sala de aula, sala de vídeo, cinema, circo, terraço de prédio, auditório - a variedade foi grande.

Se o espaço tinha recursos de iluminação, maravilha!! Se não tinha, paciência... E se o eu-atriz se rebelava:

- Não entro em cena sem refletor!

O eu escritora logo acudia:

- Mas o que que você tava pensando? Que ia encontrar o Lytelton? O Oliver? É palco do Nacional Theatre que você tá querendo, é?

- Mas olha aí o terror dessa luz fluorescente!

- Paciência, não é?

- Paciência coisa nenhuma! Atriz nenhuma entra em cena com uma luz dessas.

- Mambembe entra em qualquer cena e com qualquer luz, tá?

- E vê só, não tem porta pra fechar! Olha essa barulhada que tá vindo lá da rua. Eu não me apresento desse jeito. Eles que deem uma desculpa qualquer pro público.

- Ora, deixa de frescura. Já pra cena!

- Não vou.

- Vai. E vai já!!

E pronto: a voz do eu-escritora é sempre mais forte. ${ }^{7}$

Essa relação entre livro e palco muitas vezes é explicitada em:

* Os colegas, obra de 1972, em que as personagens se envolvem em cenas de Carnaval e de circo, universos estes extremamente teatrais;

* Angélica, obra de 1975, que apresenta, dentro da narrativa, a elaboração e a encenação de uma peça teatral feitas pelas próprias personagens do livro;

* A casa da madrinha e Corda Bamba - obras de 1978 e 1979, respectivamente - , que apresentam cenas circenses que se aproximam do teatro, por haver o improviso e a arte corporal;

* O meu amigo pintor, de 1987, em que há um capítulo que retrata um sonho sobre uma peça teatral entre a personagem principal da obra e o Pintor, que teria morrido e estaria se comunicando via sonho;

* Paisagem, de 1992, obra em que uma das tramas se passa em um teatro e outra trama apresenta a comparação da paisagem, assunto da narrativa, a um cenário de teatro;

\footnotetext{
${ }^{7}$ BOJUNGA, Lygia. Feito à mão. 4. ed. Rio de Janeiro: Casa Lygia Bojunga, 2008, p.116.
} 
* Seis vezes Lucas, de 1995, que é uma obra em que a presença de uma máscara propriamente o símbolo do teatro - é recorrente e importante na construção identitária de Lucas;

* O abraço, obra de 1995, em que há a representação de uma peça de teatro e de cenas que envolvem circo, palhaço e máscara;

* Querida, de 2009, obra em que uma das personagens é atriz de teatro e representa peças em sua residência, inclusive utilizando máscaras;

* Intramuros, de 2016, obra em que a protagonista é apresentada ao leitor em um palco, e o texto literário é marcado por indicações cênicas.

A relação entre livro e palco é tão explícita e intensa que duas obras da autora tornaram-se, posteriormente, textos de teatro propriamente ditos: Nós três, de 1987 que, em 1989, ganha sua independência como peça teatral; e $O$ meu amigo pintor, do mesmo ano que Nós três, teve seu título modificado para $O$ pintor, em 1989, passando a texto cênico.

Assim sendo, o teatro, arte pautada no diálogo, vive com tanta força nas obras bojunguianas que se torna a expressão mais intensa das experiências e da realidade:

A escolha do teatro como manifestação artística a interagir com o texto literário que se apresenta ao leitor não é aleatória. Essa escolha reforça a ideia do diálogo como força expressiva, da troca como um caminho para recriar experiências, ampliando-as e, assim, modificando o olhar que se devolve ao outro e à realidade. ${ }^{8}$

Nesse sentido, os elementos teatrais que permeiam a obra de Bojunga não têm apenas uma função estética no texto, mas também de potencialização do contato com novas experiências que podem ter o poder de transformar o modo como se percebe as pessoas, o mundo e seus problemas.

Outra aproximação entre as narrativas de Lygia Bojunga e o teatro é o processo de criação. A arte teatral inicia-se com a produção do texto que será encenado no palco. Essa produção não ocorre no palco, em contato com outras pessoas, mas na solidão do ato de escrever, momento esse com o qual Bojunga se identifica:

Mas o cotidiano da vida teatral (pra não falar no cotidiano dos estúdios da Televisão!), quando a convivência com tantas e diversas pessoas é fator obrigatório,

\footnotetext{
${ }^{8}$ RAMALHO, Denise do Passo Trocando tarefas: meu caso de amor de leitora com a obra de Lygia Bojunga. 2006. 122 f. Tese (Doutorado em Literatura Brasileira) - Departamento de Letras do Centro de Teologia e Ciências Humanas, Pontifícia Universidade Católica- RJ, Rio, Rio de Janeiro, p.69.
} 
sempre esteve em desacordo com o meu temperamento - o que gerou um conflito: o fascínio pela coisa, e a infelicidade de viver a coisa.

Como a minha necessidade fundamental é a de mexer com as palavras e criar personagens (e assim ir exorcizando fantasias, fantasmas, crenças e preocupações), um dia eu me dei conta que o canal adequado pra fazer conviver a minha necessidade fundamental e a minha inclinação temperamental era a Literatura, isto é: a magnífica solidão de uma mesa de trabalho (de preferência encostada numa parede vazia). ${ }^{9}$

É no processo artesanal da escrita, na solidão, que Lygia Bojunga consegue construir textos que, ao serem lidos, transformam-se fácil e imediatamente em uma peça teatral na mente do leitor. Assim sendo, a solidão é um sentimento importante para a autora, que consegue uni-lo ao teatro; porém, não ao teatro que ocorre sobre o palco, mas sim ao teatro que ela mesma pode criar, por meio de sua literatura, a qual é desenvolvida a partir do isolamento da autora. Como exemplo, pode-se citar um capítulo da obra Feito à mão, chamado Crow's nest. Nesse capítulo, Bojunga conta sobre como surgiu o estúdio em Londres, onde escreveu partes de suas obras:

Desde que eu comecei a fazer literatura, venho sentindo uma necessidade cada vez maior de me isolar quando eu escrevo. Sempre levei muito tempo pra 'esquentar' pra sintonizar numa mesma faixa a minha imaginação, a minha disciplina e o meu raciocínio. Qualquer interferência - a conversa do lado, o telefone tocando, um barulho de televisão - faz logo a minha faixa sair do ar. Então o estúdio (e eu traduzo o estúdio por um espaço assim: pode até ser mínimo, mas, durante o tempo em que a gente é guardião dele, ele é só da gente e pronto; e também: um espaço onde a gente tenha ao alcance das mãos as ferramentas que tenha prazer em usar no trabalho que quer realizar), então, pra mim, o estúdio se tornou tão essencial quanto o ato de escrever. Sem eles, eu vou mal, obrigada. ${ }^{10}$

Esse processo solitário de criação literária acontece por meio do espaço que a autora necessita para se isolar da realidade, a fim de iniciar o processo imaginativo, que baliza suas criações literárias. Em algumas obras em que a metalinguagem predomina, expõe-se que o processo de criação das personagens surge com o diálogo imaginativo direto entre autora e personagem, sendo esse um dos motivos de a solidão ser essencial para autora, já que é nesse momento em que o universo literário fluirá.

Literariamente, esse processo resulta em um texto semelhante ao texto teatral, uma vez que o uso recorrente de diálogos dá vida às personagens no momento da leitura:

Os eventos e as situações postos em cena, tanto em Fazendo Ana Paz como em Retratos de Carolina, não são propriamente narrados, mas presentificados ao leitor, como se eles se passassem vivamente diante de seus olhos. Desse modo, tem-se a prevalência do mostrar (showing) sobre o narrar (telling), o que gera um expressivo

\footnotetext{
${ }^{9}$ Apud SANDRONI, Laura. De Lobato a Bojunga: as reinações renovadas. Rio de Janeiro: Agir, 1987 , p. 169.

${ }^{10}$ BOJUNGA, Lygia Feito à mão, 4. ed. Rio de Janeiro: Casa Lygia Bojunga, 2008, p. 59.
} 
efeito de teatralidade, presente em menor ou maior grau em todas as obras da autora. ${ }^{11}$

O "mostrar" acaba tornando-se mais marcante e presente que o "narrar", porque Bojunga sempre teve como sua técnica particular grande parte de sua escrita em forma de diálogos. Em uma entrevista, foi perguntado à autora o que a levou à literatura e por que optou inicialmente por escrever para crianças e para jovens, na resposta à menção à forma dialogada de escrita:

\begin{abstract}
Meu gosto pela escrita foi resultado da minha paixão pela leitura. Paixão que começou em criança, quando penetrei no Sítio do Pica-Pau Amarelo e devorei todos os livros que o Monteiro Lobato situou naquele sítio. Comecei, então, a escrever umas historinhas e, depois, brincar de representar as histórias, com meus amigos. Brincadeira que - como adolescente - repetia na escola. Nos meus vinte anos, fui desenvolvendo uma familiaridade crescente com a forma dialogada de escrever.

Tudo que eu escrevia era em diálogo. E comecei, então, a escrever profissionalmente. Primeiro para o Rádio, depois para a Televisão. Até que, um dia, me perguntei: mas se meu companheiro inseparável é o LIVRO, por que não tentar alargar esse relacionamento e enveredar pela literatura? Enveredei. E, se optei, inicialmente, por uma literatura voltada para crianças foi por achar - talvez erradamente - que a transição do diálogo para a narrativa me seria menos difícil se eu usasse uma linguagem simples, coloquial, ao alcance de qualquer criança. Pensei que, desse modo, o gênero narrado ficaria mais ao meu alcance, também. ${ }^{12}$
\end{abstract}

Embora escrever de modo dialogado possa aparentar um recurso mais fácil, Lygia Bojunga admite ser essa ideia errônea. O trabalho com a coloquialidade e a aproximação com o universo infantil e juvenil, por meio de toda uma construção linguística, é um trabalho literário, que permite maior verossimilhança à obra. Essa construção é formada por vários tipos de coloquialismos, entre eles o fonético, o morfológico, o sintático, o lexical, que podem ser percebidos já na primeira obra da autora, Os colegas. Na cena inicial, há dois cachorros que se conhecem revirando a mesma lata de lixo:

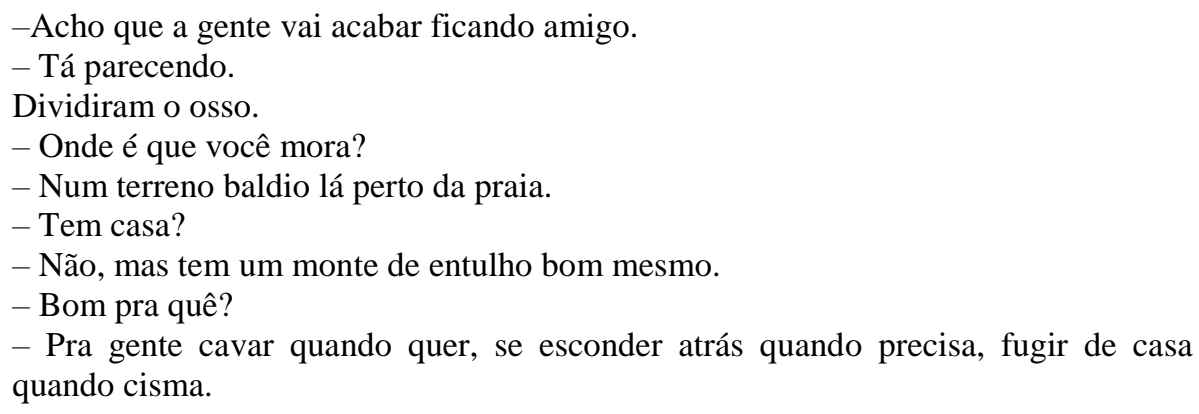

\footnotetext{
${ }^{11}$ ANDO, Marta Yumi. Fazendo retratos e experimentos: a performance da linguagem em Lygia Bojunga. 2011. 224 f. Tese (Doutorado em Letras). Universidade Estadual Paulista Júlio de Mesquita Filho, UNESP, Instituto de Biociências, Letras e Ciências Exatas,São José do Rio Preto, p.173.

${ }^{12}$ MEYER, Manoela. Literatura - Lygia Bojunga Escritores. Educar para crescer, São Paulo, 09 abr 2012.

Disponível em: http://educarparacrescer.abril.com.br/leitura/lygia-bojunga-681657.shtml. Acesso em: 05 mai.2019.
} 
- Vou lá ver.

Quando chegou, gostou um bocado do lugar.

- Tá me dando uma vontade de cismar que é minha casa...

Acabou cismando. E logo descobriram que, em samba, um gostava mais de bolar a letra, o outro, a música. Fizeram então o primeiro samba de parceria:

Vida, acho você a maior

Quanto mais penso em você

Mais eu vejo que te gosto

E que não tem coisa melhor ${ }^{13}$

Nesse trecho, há coloquialismos fonéticos: uso de "num", "pra" e "tá"; coloquialismo morfológico: o uso de adjetivo "maior" sem ser em um contexto de uso de comparativo de superioridade; coloquialismo sintático: a alternância do uso do pronome de tratamento "você" e do objeto indireto referente ao pronome "tu"; coloquialismos lexicais: verbo "ter" usado no sentido de "existir", o uso de "a gente" ao invés de "nós", o uso do verbo auxiliar "vai" ao invés do emprego da conjugação dos verbos principais no tempo futuro, o termo "bocado" para expressar o advérbio de intensidade "muito", o uso da expressão coloquial "não tem coisa melhor".

Embora não sejam peças teatrais, as cenas das obras de Lygia Bojunga podem ser facilmente encenadas em virtude da sua composição pautada nos diálogos entre as personagens. A mínima presença da voz de um narrador observador funciona como rubricas básicas de indicações cênicas, o que permite maior atenção às vozes das personagens. Essa estrutura narrativa prestigia a ação realizada por meio dos diálogos em detrimento da ação indicada pela narração de um narrador que não é personagem.

Um exemplo de como o narrador na obra bojunguiana indica as didascálias ${ }^{14}$ do teatro ocorre em A casa da madrinha. Embora haja vários personagens narrando suas experiências, essa narração é sempre feita, predominantemente, em forma de diálogos, com uso de primeira pessoa e dos verbos no presente do indicativo. A sobreposição dessas narrativas em forma de diálogos adia o desfecho da narrativa principal: a busca pela casa da madrinha. Logo, com o passar do desenrolar das cenas, o desfecho é cada vez mais esperado. Por ser uma obra constituída de narrativas feitas pelas próprias personagens, aparenta que a história será mais narrada que dialogada. Assim, quase não aparece o narrador observador, quando ele tem voz na narrativa é relativo a rubricas ou didascálias dos textos teatrais, pois só aparece para

\footnotetext{
${ }^{13}$ BOJUNGA, Lygia. Os colegas. 52. ed. Rio de Janeiro: Casa Lygia Bojunga, 2014, p.13.

${ }^{14}$ Instruções dadas pelo autor e seus atores (teatro grego, por exemplo), para interpretar o texto dramático. Por extensão, no emprego moderno: indicações cênicas ou rubricas. In: PAVIS, Patrice. Dicionário de teatro. São Paulo: Perspectiva, 2015, p.96.
} 
mencionar a mudança de espaço e, às vezes, a mudança do foco narrativo. Esse narrador é construído em terceira pessoa e é importante para costurar as narrativas que aparecem de modo a contextualizar o leitor sobre o assunto abordado e a personagem que está falando em um determinado trecho.

O diálogo é, portanto, um dos recursos teatrais mais básicos utilizados pela autora na construção imagética de suas personagens. A seguir, recursos diferentes serão analisados.

\title{
2.2. A TEATRALIDADE NA CONSTRUÇÃO IMAGÉTICA NA LITERATURA DE LYGIA BOJUNGA
}

A literatura, como arte construída predominantemente por meio da linguagem verbal, pode se valer de vários recursos de outras artes, a fim de elaborar um universo imagético. Nesse sentido, tanto a palavra pode se tornar imagética, quanto uma imagem pode ser feita verbalmente. É fundamental abordar esse processo literário, visto que o teatro, por fazer parte da literatura de Lygia Bojunga e por ser uma arte visual, é a principal perspectiva da presente análise.

Também é importante salientar que o diálogo entre as artes não se restringe à literatura:

\begin{abstract}
Boa parte dos primeiros críticos teóricos procuravam definir o cinema como meio e a sua relação com as demais artes. Citando Lessing, Wagner e os futuristas, Riccioto Canudo, em seu manifesto 'O manifesto de uma sexta arte' (1911), previa que o cinema absorveria as três artes espaciais (arquitetura, escultura e pintura) e as três artes temporais (poesia, música e dança), transformando-as em uma forma sintética de teatro designada 'Arte Plástica em Movimento'(Abel, 1988, vol I, pp. 58-66). ${ }^{15}$
\end{abstract}

Nessa concepção de cinema, além de ele ser múltiplas artes em uma só, é denominado como uma forma sintética de teatro, por isso está tão imbricado tanto a este quanto a outras artes. Sendo assim, é um dos recursos mais utilizados na construção imagética da literatura de Lygia Bojunga.

Parte-se, portanto, da conjugação de recursos do teatro e de outras artes para que se possa analisar a interação entre a linguagem literária e a linguagem das demais artes, como forma de criação da teatralidade literária. Essa teatralidade, na obra de Bojunga, é obtida com

\footnotetext{
${ }^{15}$ STAM, Robert. Introdução à teoria do cinema.Tradução Fernando Mascarello.São Paulo: Papirus, 2000, p.43.
} 
maior recorrência e intensidade nos processos de construção da caixa cênica e, consequentemente, de todos os elementos que a envolvem, tais como os cenários, a iluminação, as personagens e as cenas. Vale ressaltar que o objetivo não é analisar por inteiro esses recursos de outras artes, mas mostrar a intersecção existente entre a linguagem literária e a teatral. Também é de suma importância adiantar que as obras da autora analisadas dentro dessa perspectiva voltarão a ser analisadas em outro momento do trabalho, por meio de outras abordagens mais relacionadas ao teatro.

Por uma questão didática, cada um dos recursos das diferentes artes analisadas cinema, música, pintura, dança e fotografia - será abordado separadamente, embora se tenha a compreensão de que nem sempre essas linguagens encontram-se desvencilhadas.

\section{Cinema}

Lygia Bojunga consegue erguer literariamente o cenário do picadeiro na obra $O s$ colegas com o uso da descrição, que, aliada ao foco narrativo, cria a imagem de movimentos cinematográficos:

\footnotetext{
Latinha apontava o picadeiro:

- Olha só quanta coisa legal!

Tinha o homem que engolia espada, tinha os equilibristas, os gigantes e os anões. Tinha os cachorros que jogavam futebol e as moças lindas que - como é que pode? comiam fogo. Tinha os cavalos e os elefantes que dançavam bem que só vendo, e tinha a mulher com uma barba enorme e o homem sem barba nenhuma, mas que em compensação andava de bicicleta de tudo quanto era jeito. Tinha leões. Tinha acrobatas. E tinha criança à beça sentada nas arquibancadas. Tinha gente vendendo bala, amendoim, pipoca estalando. Tinha balões pelo ar. E orquestra tocando. Tinha barulho de gente e de bicho. E melhor do que todos, melhor do que tudo, tinha os palhaços também. ${ }^{16}$
}

A descrição não apenas do que havia sobre o cenário do palco do circo, mas também de todo o picadeiro, incluindo a plateia, é feita por meio de um narrador em $3^{\mathrm{a}}$ pessoa que funde a sua descrição com a visão da personagem. O modo como esse processo é realizado remete ao olhar de uma câmera de cinema que reconhece todo o espaço por meio do movimento chamado travelling, no qual " a camera como um todo muda de posição, indo em

\footnotetext{
${ }^{16}$ BOJUNGA, Lygia Os colegas. 52.ed. Rio de Janeiro: Casa Lygia Bojunga, 2014, p.24.
} 
qualquer direção ao longo do chão, para frente, para trás, circulaermente, diagonalmente ou de um lado para o outro."

Apesar de haver distinções entre a linguagem literária e a linguagem cinematográfica, diferenças essas que não são objeto deste trabalho, é interessante mencionar uma delas para que se possa notar como ambas as linguagens podem ser construídas de modo interligado:

O cinema é mais exterior, e neste sentido ele instaura um mundo, enquanto a literatura, mais interior, recria um mundo. Efetivamente, o cinema omite a experiência subjetiva, porque para ele tudo deve ser sempre objetivado pelo olho da câmera, transformado no olho do espectador, ainda que um olho parcializador da exibição do corpo, da paisagem ou do mundo.

Mas é exatamente aqui que o cinema realiza aquela representação segunda, sem deixar de ser natural - ele cria imagens que, a rigor, não se encontram na natureza, pois o cinema não fala das coisas, como a literatura, mas as mostra, e cada imagem singular tem o poder gerador de uma nova experiência de um mundo visível ${ }^{18}$

Considerando essa ideia, o trecho que descreve o espetáculo circense e seus arredores é cinematográfico, visto que representa objetivamente o olhar do espectador, no caso a personagem, que, ao mesmo tempo, é o olhar do leitor, que, diante da visualização de tal cenário, também se coloca como espectador diante da caixa cênica. Além disso, o narrador observador confere ao registro verbal intensa carga imagética que auxilia a composição cênica, por meio de técnicas de enquadramento do cinema, como pode ser observado em Corda bamba, no capítulo Márcia e Marcelo. A protagonista Maria, ao andar na corda, adentra o universo do imaginário e vê seus pais; porém, estes não a veem:

Viu um rapaz deitado, se assutou: não estava esperando encontrar ninguém; perdeu o equilíbrio, sentiu que ia cair; se não se agarra na corda do andaime, caía mesmo. $\mathrm{O}$ andaime balançou pra cá, pra lá, mas o rapaz não se mexeu: estava dormindo. E quando o arco caiu e tapou a cara dele de flor, ele nem acordou.

Maria pulou pro andaime, se abaixou e pegou o arco. Parou. Fascinada. Mal podendo acreditar. O rapaz era igualzinho ao pai dela, só que mais moço.Usava um macacão sujo de tinta, boné e sapato de lona. Maria mal podia respirar de tão emocionada. Foi se ajoelhando ao lado do rapaz: queria ver de mais pertinho como ele era igual ao pai. E quando ia estendendo a mão pra fazer uma festa nele, ouviu uma voz dizendo 'Oi! Acorda!', e só de ouvir a voz o coração deu um esbarrão no peito e ela toda se virou pra olhar. Tinha uma moça debruçada na janela, igualzinha à mãe dela, rindo pra ela! E aí Maria riu também de tão contente. E levantou. E chegou junto da moça, pra abraçar, pra falar, pra - mas, ué!, a moça não via ela. Estava rindo era pro rapaz; era pro rapaz que estava dizendo: 'Acorda!'

E o rapaz acordou. E também nem viu Maria nem nada. ${ }^{19}$

\footnotetext{
${ }^{17}$ BORDWELL, David; THOMPSON, Kristin.A arte do cinema: uma indtrodução. Tradução de Roberta Gregoli. - Campinas, SP: Editora Unicamp; São Paulo, SP: Editora da USP, 2013, p.315.

${ }^{18}$ PEREIRA, Olga Arantes. Cinema e Literatura: dois sistemas semióticos distintos. Revista Kalíope, v.5, n.10, 2009. Disponível em: https://revistas.pucsp.br/kaliope/article/view/7471/0. Acesso em: 09 jun.2019.

${ }^{19}$ BOJUNGA, Lygia. Corda bamba. 24. ed. Rio de Janeiro: Casa Lygia Bojunga, 2009, p. 71 e 72.
} 
Nesse trecho, o narrador em $3^{\text {a }}$ pessoa assume um olhar que acompanha, etapa a etapa, não apenas as ações de Maria, mas também as descobertas da menina em relação aos pais, o que torna esse narrador também observador. O foco narrativo capta também as ações que ocorrem no espaço abaixo de Maria tal qual o enquadramento plongée (palavra francesa que significa "mergulho") - quando a câmera está acima do nível dos olhos, voltada para baixo. Também chamada de "câmera alta". ${ }^{20}$ É a partir desse olhar aéreo que é possível a protagonista reconhecer o pai e, ao mesmo tempo, este ser apresentado e construído fisicamente pelo tipo de indumentária humilde que possuía. No meio tempo em que se desequilibra e reconhece o pai, a personagem mãe é inserida e visualizada de baixo para cima - como no recurso do cinema contra-plongée, em que a câmera está voltada para cima -, visto que ela estava acima de Maria. Todos esses movimentos espaciais são construídos a partir da descrição verbal do local onde cada personagem se encontra.

Outros recursos do cinema que tornam a literatura de Bojunga imagética são recursos visuais que remetem à iluminação das cenas. Alguns desses recursos são usados em obras, como $O$ abraço e Querida, e tornam a construção cênica mais verossímil e vívida. Na obra $O$ abraço, a utilização das cores preta e branca como forma de construir verbalmente a imagem de pouca iluminação contribui para a visão de uma personagem fantasmagórica e ambígua, como ocorre na cena em que Cristina é levada de carona até a festa misteriosa da qual irá participar:

\footnotetext{
Chegamos no tal endereço. Uma casa bonita, lá no alto da Gávea, jardim em volta, acabando na mata que sobe pela montanha. Estranhei:

- Pouca luz pr'uma festa, não é?

- Me espera um instantinho que eu vou ver se é aqui mesmo.

Saiu do carro, atravessou o jardim e tocou a campainha.

Fiquei espiando. Quem abriu a porta foi uma figura em preto e branco (...) Conforme ela abriu a porta, os braços também se abriram, feito coisa que ela ia colher a Cristina num abraço. Mas o gesto logo se paralisou. As duas trocaram umas palavras, a figura sumiu dentro da casa e a Cristina voltou correndo pro carro. ${ }^{21}$
}

Essa é a descrição feita pelo narrador-personagem, que estava dirigindo e vê o local de dentro do carro, portanto é um olhar, como no do cinema, de plano aberto, já que a casa, que é o objeto de interesse da narrativa nesse momento - onde se passa a festa e a morte da protagonista -, torna-se secundária diante do amplo espaço que há em sua volta, assim sendo, o narrador destaca esse plano aberto ao invés de enquadrar somente a casa, visto que é da casa

\footnotetext{
${ }^{20}$ STOA USP. Disponível em: https://social.stoa.usp.br/articles/0047/2919/Planos_de_enquadramento_6_.pdf. Acesso em: 28 jul.2019.

${ }^{21}$ BOJUNGA, Lygia. O abraço. 6. ed. 3. imp. Rio de Janeiro: Casa Lygia Bojunga, 2014, p. 75.
} 
para a mata que será o trajeto do assassinato de Cristina. Como forma de anunciar esse ambiente perigoso e fantasmagórico, na sequência do plano aberto, o narrador-personagem chama a atenção para a pouca iluminação do local, que já se é imaginada anteriormente pelo leitor por se tratar de uma mata que adentra montanhas. A baixa iluminação explica a escolha do termo aforme "figura" para se referir à imagem. Ademais, há a ambiguidade da expressão "colher a Cristina num abraço", porque pode-se tratar de conseguir um abraço ou segurar a protagonista em um abraço de cumprimento ou pode-se tratar do sentido figurado de o abraço ser a morte e de o verbo colher estar sendo usado na acepção de apanhar, derrubar, apanhar de surpresa. Essa ambiguidade, além de ser captada lexicalmente, também é retratada pelas vias teatrais e cinematográficas do gesto, haja vista que o gesto do abraço se paralisa. Essa paralisação é feita literariamente via efeitos cinematográficos, já que o narrador se aproveita da imagem do movimento da porta que se abre para engatar a imagem dos braços que se abrem juntamente com a porta, aparentando uma cena natural de cumprimento, mas, ao mesmo tempo, fantasmagórica.

Em Querida, a oscilação entre o claro e o escuro, o que remete tanto à iluminação cênica quanto à iluminação cinematográfica, somada à maneira como o olhar do narrador se desloca, confere movimento e vivacidade à cena:

\begin{abstract}
Uma lua quase cheia se aproveitava das venezianas abertas e entrava pela vidraça pra vir clarear o quarto. De leve.

Passava de meia-noite quando o Pollux acordou com frio. (...)

O pássaro noturno gritou de novo e mais alto. O Pollux se ergueu assustado e olhou para a cama do Pacífico. Ele dormia em sono solto. O Pollux se levantou devagar e foi indo pra janela. Parou junto da mesa e tentou enxergar lá fora. Uma nuvem tinha escondido a lua. Ele já ia voltar pra cama quando a lua reapareceu pra clarear a cena. O coração do Pollux despencou: uma mulher, sentada num dos bancos do jardim, falava e gesticulava, e o Pollux olhava pra tudo quanto é canto que a janela mostrava e não via mais ninguém além da mulher. Quanto mais ele olhava pra ela, mais entranha ela parecia: o cabelo era comprido e de uma brancura que chegava a brilhar; uma túnica também branca, debruada de cetim prateado e quase arrastando no chão, cobria a mulher todinha. Feito coisa que a noite era quente, a mulher estava descalça e o pé parecia acompanhar no gramado os gestos que a mão fazia. ${ }^{22}$
\end{abstract}

A autora opta por termos do campo semântico da iluminação, além de fazer uma escolha lexical precisa da caracterização do cenário noturno, como "lua quase cheia" - o que indica que havia parte do cenário sem iluminação -, noite, noturno, meia-noite. Esses recursos de iluminação auxiliam a ambientação da cena e preparam-na para a construção imagética do movimento do céu para o quarto. Esse movimento é feito, verbalmente, por meio da personificação da lua, que "se aproveitava" das venezianas. Com essa figura de linguagem, a

\footnotetext{
${ }^{22}$ BOJUNGA, Lygia. Querida. Rio de Janeiro: Casa Lygia Bojunga, 2009, p. 64 e 65.
} 
autora consegue passar da lua às janelas do quarto em instantes, tal como uma câmera de cinema. Ademais, a iluminação também é essencial no enquadramento do olhar da personagem Pollux, que, por causa da baixa iluminação, redobra o esforço para enxergar através do espaço da janela. Nota-se que esse enquadramento é feito pela janela do quarto, sendo essa a limitação do campo de visão, assim como o de uma câmera. Os efeitos de iluminação também auxiliam na descrição fantasmagórica feita de Ella, uma vez que a personagem está falando sozinha após a meia-noite e é totalmente branca e prateada, o que permite um contraste total com a escuridão da noite onde ela se encontrava.

\title{
Música
}

Com relação aos recursos da música, é importante considerar o seu caráter textual e musical:

\begin{abstract}
Será para fazer uma muleta da imaginação musical que se recorre a um texto poético? Todavia, Boulez evoca o 'tecido de conjunções' que o músico deve tecer entre o texto e a música e que, 'entre outras, comporta as afectivas, mas engloba, além disso, todos os mecanismos do poema da sonoridade pura ao seu estilo inteligente. ${ }^{23}$
\end{abstract}

Nota-se que a música não se restringe ao universo da imaginação ou dos sentimentos, visto que ela se faz por meio de recursos sonoros. Dessa forma, os recursos da música utilizados na literatura de Bojunga, além de expressarem relação com a temática da obra em questão, propiciam a sinestesia auditiva, o que é essencial para se potencializar recursos teatrais utilizados na literatura.

Desde Os colegas, há diversos recursos de arte na literatura de Lygia Bojunga, que valorizam a oralidade na construção das cenas teatralizadas. Um deles é a inserção de letras de sambas ao longo da obra, que são representadas verbalmente por versos. Elas têm a função de comentar as cenas da narrativa, ajudando, portanto, no processo de construção cênica. Um exemplo é a inserção da letra de samba, em versos hexassílabos, no momento da narrativa em que Latinha se encanta ao conhecer Flor:

Flor-de-lis, Flor-de-lis

Ai, flor que sempre quis.... ${ }^{24}$

\footnotetext{
${ }^{23}$ BOUCOURECHLIEV, André. A linguagem musical.Tradução de António Maia da Rocha. Lisboa: Ed. 70, 2003, p.13.

${ }^{24}$ BOJUNGA, Lygia Os colegas. 52.ed. Casa Lygia Bojunga, Rio de Janeiro: 2014, p.16.
} 
Outro exemplo é a cena em que Flor se lembra do samba de Virinha e de Latinha por não ter conseguido colocar seu plano em prática, já que não era alfabetizada. O momento de resgate dessa lembrança é teatralizado por meio do poder visual que a música produz, já que o leitor imagina a personagem cantando. Todo esse processo é possível graças à transcrição da letra do samba, que é composto por versos alexandrinos, justamente um dos que são mais rebuscados, o que contrasta com o assunto sobre o qual o samba trata:

Tudo na vida tem um jeito, meu compadre
Só sê inguinorante é que num dá pé
Num só a gente vive naquele vinagre
Como só pode fazê o que os outros qué

Além disso, os sambas antecipam alguma cena da narrativa, tornando possível já visualizá-la com antecedência. No capítulo Corrente de prata é bacana de se usar?, em que as outras personagens ajudam Flor a fugir de sua dona, por exemplo, o samba não apenas sugere o modo como ocorrerá a fuga - a dona de Flor largará a corrente de prata que prende a cadela -, como também responde ao título do capítulo:

\author{
Andaram dizendo por aí: \\ 'Corrente de prata é bacana de se usar' \\ Mas há muito tempo já compreendi \\ Que seja de prata, seja de lata, \\ Corrente só serve pra chatear. ${ }^{26}$
}

A escolha por esse gênero musical torna-se um recurso literário, pois está relacionada à cultura popular abordada na obra - não apenas o Carnaval, como também o circo -, além de visualmente ser separada da narrativa principal por ser escrita em versos e grafada em itálico, respeitando a eufonia que a música deve ter.

Outrossim, no capítulo A grande farra, em que as personagens comemoram o carnaval, há a representação literária da música por meio de uma onomatopeia que reproduz o ritmo da cuíca:

Voz de Cristal, com toda aquela força que tinha, e mais um entusiasmo enorme, fazia a cuíca roncar como nunca ninguém tinha feito: rom-rom-rom, rom-rom-rom, rom-rom-rom, rom-rom-rom (e às vezes roncava tão bonito que ele se comovia e chorava). ${ }^{27}$

\footnotetext{
${ }^{25}$ BOJUNGA, Lygia Os colegas. 52.ed. Rio de Janeiro: Casa Lygia Bojunga, 2014, p.79.

${ }^{26}$ Ibid., p.105

${ }^{27}$ Ibid., p. 44.
} 
O uso de hífen representa o momento de pausa temporal menor entre os sons, e o de vírgula, o maior. Essa construção verbal proporciona vivacidade à cena da personagem tocando, como se ela estivesse em um espetáculo.

\title{
Pintura
}

No caso da obra Paisagem, a paisagem descrita pela personagem Lourenço tem cores, que intensificam a visualidade dos elementos descritos:

\begin{abstract}
era uma paisagem assim: tinha um campo de flor, flor branca, flor amarela vermelha e azul, mas tudo que é flor de repente parava e começava um areão que ia indo e ia indo e acabava lá no mar; tinha uma pedra nesse areão; às vezes era pedra sozinha, às vezes era um monte de pedra, às vezes elas tinham cara de ruína de antigamente; olhei pro lado e vi um pedaço duma casa feito da mesma pedra que tinha na areia, fiquei pensando se a casa estava sendo construída ou se era tão velha que já tinha perdido um pedaço; tinha sol no campo de flor, mas em compensação no areão não tinha, e o mar e o céu era cinzento; tinha um barco no mar, e eu me lembro que eu fiquei olhando pra ele e pensando pra onde é que esse barco tá indo? ou será que ele tá voltando? de repente uma coisa chamou a minha atenção lá na areia: tudo que é pedra tinha a mesma forma quadrada, mas uma delas era diferente, parecia um ovo enorme, e me deu uma vontade danada de ir lá examinar melhor, mas eu não sabia onde é que eu estava, às vezes eu pensava de onde é que eu tô vendo essa paisagem? é do campo de flor? é de dentro da casa? é do mar? eu só sabia que eu estava ali vendo uma paisagem que quanto mais eu olhava mais eu tinha certeza que ela tinha sido escrita por você. ${ }^{28}$
\end{abstract}

As cores, além de exprimirem pictoricamente os detalhes do cenário paisagem, envolvem o leitor na construção imagética desse cenário, visto que ela vai sendo mais detalhada ao longo do desenvolvimento de cada trama da obra. São também pistas para se desvendar o mistério sobre a coincidência de esse cenário ser o mesmo de outras tramas, o que torna o leitor mais envolvido no jogo estas: "Na paisagem do Lourenço também só tinha uma pedra diferente das outras. E aí eu fiquei pensando se ele tinha mencionado a cor das pedras. Levantei e fui ler a carta de novo. Não tinha." 29

A ausência de informação sobre a cor das pedras leva à inquietação, à curiosidade; porém, quando finalmente essa informação é revelada, a referência a outras cores torna ainda mais detalhado o aspecto pictórico da paisagem das diferentes tramas:

A casa tem janela sim... (Tem? Mas por que que ele não dizia tinha?)... tem uma janela só, perto da porta, e as duas tão pintadas de verde, e as pedras têm uma cor rosada...

\footnotetext{
${ }^{28}$ BOJUNGA, Lygia. Paisagem. 7.ed. Rio de Janeiro: Casa Lygia Bojunga, 2013, p.12 e 13.

${ }^{29}$ Ibid, p. 21.
} 
Eu estava tonta: não se tratava mais de uma paisagem parecida, era uma paisagem igual. $^{30}$

Também o que se pinta por meio de palavras adquire aspecto de teatralidade no processo de construir a iluminação de um cenário e de representar personagens em sonho, como acontece na obra $O$ meu Amigo Pintor.

Há uma cena em que o protagonista narra um sonho que teve com seu falecido Amigo Pintor, sonho esse que se passou em um teatro. Neste, a iluminação no palco é feita literariamente a partir das cores:

\footnotetext{
O relógio começou a bater bonito.

Contei doze pancadas.

Não dava pra saber se era meio-dia ou meia-noite: a cor não ficou nem mais de noite nem mais de dia.

E depois que o relógio parou de bater, as três figuras entraram no palco. Do mesmo tamanho, as três andando bem junto, uma branca e duas azuis; e foi só olhar pra branca que eu vi logo que era o meu Amigo Pintor fazendo o papel do fantasma. E sabe? Fiquei aflito.

As duas outras figuras eu não sabia que papel que elas iam fazer. Mas elas eram azul tão vivo, tão forte, que jogavam um brilho no palco e faziam a cor da saudade ficar mais forte. E mais forte dentro de mim também. ${ }^{31}$
}

A partir da poeticidade construída por meio da menção às cores, Lygia Bojunga cria a iluminação da cena. Essa iluminação, em um primeiro momento, é originada a partir de sua neutralidade, isto é, nem da presença, nem da ausência de luz, já que não era noite, nem dia. Isso ocorre, por um lado, por meio do uso de metáforas que aproximam as cores escuras ao tempo mencionado pelas badaladas do relógio - a possibilidade de ser meia-noite. Assim sendo, há a criação da metáfora "cor de noite". Por outro lado, há a criação da metáfora "cor de dia”, que aproxima as cores claras ao meio-dia, possível horário sugerido pelo relógio. Não sendo nem cor de dia nem cor de noite, o palco não tem cor, nem está inserido no tempo. Dessa maneira, o palco torna-se um espaço onde pode haver luzes com destaque, que é o que acontece quando as figuras azuis jogam brilho no palco. A autora faz a iluminação, nesse caso, a partir das cores intensas das personagens que estão em cena. Ademais, há o uso do termo "figura" para se referir àquilo que não se pode dar uma forma exata, assumindo um teor fantasmagórico, porém diferente de $O$ abraço, já que, embora o Amigo Pintor seja um fantasma branco, a cena vista faz o protagonista reconhecer a intensificação da cor da saudade, o que proporciona à cena não apenas poeticidade, mas também emoção, ambas expressas verbal e imageticamente por todos esses recursos.

\footnotetext{
${ }^{30}$ BOJUNGA, Lygia. Paisagem. 7.ed. Rio de Janeiro: Casa Lygia Bojunga, 2013, p.25 e 26.

${ }^{31}$ NUNES, Lygia Bojunga. O meu amigo pintor. Rio de Janeiro: José Olympio, 1987, p.25.
} 
A literatura de Lygia Bojunga também se faz de modo teatralizado por intermédio de recursos pictóricos que expressam tonalidades. É o caso do capítulo em que a personagem Quico, de Corda bamba, tem um sonho:

Cada sonho lindo. Variava: às vezes era tudo preto e branco; às vezes era cheio de cor; às vezes, era amarelo só. E tinha dias que ele sonhava e acordava, sonhava e acordava tanto que, ficava até sem saber quando era sonho ou não era.

(...)

Quico foi dormir e já sonhou com um orelhão. Um sonho amarelo. Barbuda era amarela, tinha uma orelha enorme e amarela, e a barba era tão amarela que doía no olho. E aí Quico sonhou que o orelhão usava brinco - amarelo bem clarinho. Acordou. Dormiu. Acordou. Dormiu. Sonhou de novo com o orelhão de brinco. Mas dessa vez era tudo branco e preto. Acordou. Sonhou. Acordou. Sonhou. Sempre com o orelhão de brinco, sempre preto e branco. Mas, de repente, o sonho mudou. E mudou pra colorido também, Quico desatou a ver tudo cheio de cor. ${ }^{32}$

A instabilidade inicial das cores é demonstrada pelo uso de advérbios, o que passa a ser, posteriormente, a mudança de tonalidade da cor amarela, que vai da mais intensa representada pela sinestesia "doía no olho" - à menos intensa - construída por meio do diminutivo do adjetivo "claro", que é ainda mais atenuado pelo advérbio "bem".

Nesse mesmo capítulo, há a narração de um sonho em que a tonalidade marca a mudança do tempo e, consequentemente, a do cenário:

O dia estava nascendo, um dia muito bonito, com o céu cor-de-rosa fraquinho. Maria
estava de pijama listado, tinha lista branca e vermelha. Era hora de galo cantar, mas
era Copacabana: não tem mais lugar pra quintal nem jardim, não tem mais lugar pra
galo nenhum. Todo mundo estava dormindo, era um sonho quieto, muito quieto.
Quico viu Maria sair da janela e pegar o arco de flor. Flor de tanta cor. Viu Maria
olhando pro arco; depois ela voltou pra janela e ficou espiando pra baixo. Por que
Maria ia e vinha, assim de lista e pé no chão, olhando pra tudo tanto? (....)
'Onde é que você tá amarrando a corda, Maria?', Quico perguntou. Mas só
perguntou pensado: quando abriu a boca pra falar, a voz não saiu. Chamou bem alto:
'Maria! Maria!' Mas a voz não saía. Ficou com medo: 'Maria!' (A voz não saía
porque ele estava com medo, ou porque a gente sonhando a voz não sai?) Quis se
levantar e ir na janela, mas parecia colado na cama, não podia se mexer.
Quico desatou a suar. Não se mexia. Mal respirava. E agora só suspirava fraquinho:
'Maria. Cuidado, viu, Maria?'
O sol apareceu. Mas só um pouco. E o céu então foi passando pra vermelho.

Como temporalmente o início do sonho se trata de um amanhecer, o céu é pintado com uma cor monocromática "cor de rosa fraquinho", em que se tem a mistura de muita cor branca - indicando a claridade do dia - com a cor vermelha para resultar na tonalidade rosa, que é amena, contrária à cor intensa - vermelha - que aparecerá na sequência. A mistura dessas duas cores no céu já é sugerida pelas cores das listas do pijama de Maria: branco e vermelho.

\footnotetext{
${ }^{32}$ BOJUnGA, Lygia. Corda bamba. 24. ed. Rio de Janeiro: Casa Lygia Bojunga, 2009, p.49 e 50.

${ }^{33}$ Ibid, p. 50-52.
} 
A travessia da protagonista inicia-se com a total mudança do céu: passa-se do cor de rosa claro para o vermelho, transformação essa que pode ser lida, nesse contexto, como a "cor do perigo e da proibição" ${ }^{\text {"34 }}$. A proibição remete ao pedido de Quico para que Maria não suba na corda-bamba, já que é perigoso por estar tão longe do chão e sem proteção.

\title{
Dança
}

A dança é uma arte que não apenas se relaciona ao espaço como também à emoção:

\begin{abstract}
Segundo Laban (1978), a dança é um exercício de esforço (effort shape) tendo como plataforma a espacialidade e a afetividade. O corpo, desta forma, será o plano de emergência de estados interiores que são desenvolvidos no espaço através da movimentação dinâmica na cinesfera. ${ }^{35}$ "É delimitada espacialmente pelo alcance dos membros e outras partes do corpo do agente quando se esticam a partir do centro do corpo, em qualquer direção, a partir de um ponto de apoio. [...] A cinesfera também é um espaço psicológico, a partir do qual toda a expressividade guarda coerência." (RENGEL, 2003, p.37-38). ${ }^{36}$
\end{abstract}

É de extrema importância partir dessa concepção de dança, visto que a cinesfera não se restringe a um espaço físico, já que engloba também um espaço psicológico, que, por sua vez, pode ser o imaginário. Por meio do recurso da dança, a literatura de Lygia Bojunga, além de construir movimentos imagéticos, estabelece relações entre personagens e cenários (espaços), o que é fundamental para a construção cênica via literatura. Uma das cenas mais exemplares da utilização desses recursos é a que Lucas, de Seis vezes Lucas, fantasia um espaço onde ele possa se encontrar com seu grande amor, sua professora Lenor:

\footnotetext{
A Lenor começou a dançar sozinha, feito quando a Mãe tinha dito, bobagem, todo mundo sabe dançar, é só fazer assim, ó, quando a música tá tocando, assim, ó, (...) A Lenor veio dançar na frente do Lucas. (....) De que jeito? De que jeito ele ia dançar com a Lenor se ele não sabia dançar.

Parecia que o tempo tinha parado de tanto que custava a passar. Assim: a música tocando forte, a Lenor dançando pra ele, e ele doido pra dançar feito o Pai, mas sem coragem de experimentar. (...)

A Lenor dança até o armário, abre a porta, pega a máscara e traz ela estendida pro Lucas em cima das duas mãos. (....)

O Lucas gruda a Cara e fica um tempo se olhando no espelho. Vai se esquecendo do medo, a vontade de experimentar dançar vai crescendo; vê a Lenor no espelho, encorajando ele com o olho; sente o pé se mexendo, fazendo um passo de dança; o corpo vai indo atrás, fazendo assim, ó, assim; o braço vai ondulando, a mão fica tão leve! E o Lucas então se vira e começa a dançar com a Lenor.
}

\footnotetext{
${ }^{34}$ SILVEIRA, Luciana Martha. Introdução à teoria da cor. Curitiba: UTFPR: 2011, p. 133.

${ }^{35}$ Cinesfera é a esfera que delimita o espaço pessoal no entorno do corpo do ser movente.

36 Apud TEIXEIRA, Carlos Henrique; MONTEIRO, Sueli Aparecida Itman. A dança como expressão do imaginário. Revista Ibero-Americana de Estudos em Educação, p.158. Disponível em: https://periodicos.fclar.unesp.br/iberoamericana/article/download/5716/4447. Acesso em: 07 jun.2019.
} 
Não precisa mais espelho, o balão vai subindo de novo. Ora de frente um pro outro, ora um rodeando o outro, o Lucas e a Lenor dançam. E dançam e dançam. ${ }^{37}$

Esse fragmento reúne o objeto teatral máscara a recursos da dança. Estes são construídos por meio da descrição dos movimentos do pé, do braço e do corpo inteiro de Lucas, o que constitui a linguagem imagética que incentiva a imaginação do leitor. Acerca do uso da máscara no momento da dança, considerando que esse objeto está relacionado à construção identitária de Lucas, pode-se dizer que a dança é a arte que o permite expressar o indivíduo que ele gostaria de ser. Dessa perspectiva,

a dança surge como um movimento intrinsecamente ligado à expressão, à criatividade, além de ser uma atividade social, com elementos de imitação e de forma. No mesmo sentido, no que concerne à definição de expressividade, existem vários parâmetros para conceituar o termo. Alguns optam por conceituá-la como uma linguagem corporal, outros por forma de Comunicação e como uma prática voltada para o desenvolvimento de todas as potencialidades humanas, relacionadas ao movimento corporal, assim como se dá com a dança. ${ }^{38}$

Exprimir os passos de dança, portanto, não apenas coloca a personagem cenicamente no espaço que ela mesma criou, como também demonstra visualmente a formação de sua autoconfiança por meio da dança.

\title{
Fotografia
}

A fotografia é uma arte que se baseia em um referente e em sua respectiva ausência:

\begin{abstract}
A foto é literalmente uma emanação do referente. De um corpo real, que estava lá, partiram radiações que vêm me atingir, a mim, que estou aqui; pouco importa a duração da transmissão; a foto do ser desaparecido vem me tocar como os raios retardados de uma estrela. ${ }^{39}$
\end{abstract}

$\mathrm{Na}$ literatura de Lygia Bojunga, esse recurso é mais utilizado para intensificar as expressões dos referentes, imprimindo no registro verbal traços que chegam a definir as expressões das personagens em cena, tais quais atores em uma peça teatral. A própria autora ao escrever o Pra você que me lê afirma que os processos de criação de Aula de inglês e de Sapato de salto estavam imbricados aos recursos da fotografia:

\footnotetext{
${ }^{37}$ NUNES, Lygia Bojunga. Seis vezes Lucas. Rio de Janeiro: Agir, 1996, p.71-78.

${ }^{38}$ SILVA, Maria Graziela Mazziotti Soares da; SCHWARTZ, Gisele Maria. A expressividade na dança: visão do profissional. Motriz, São Paulo, v. 5, n. 2, dezembro/1999, p.169.

${ }^{39}$ BARTHES, Roland. A câmara clara: nota sobre fotografia. $3^{\text {a }}$ ed. Rio de Janeiro: Nova Fronteira, 1989, p.121.
} 
Então, dessa vez, venho conversar contigo nesse clima de envolvimento em que eu ando com todo este pessoal do Sapato e da Aula e, nesta conversa, te contar, também, que, de repente, me bateu que o capítulo final que estou dando pro Sapato é resultado de uma pessoa só: o professor, da Aula de inglês. Me dei conta de que estou sendo muito influenciada por ele e que, da mesma maneira que ele fazia com a Teresa Cristina, comecei também a querer enquadrar meus personagens do Sapato em fotos mentais, buscando na expressão fisionômica de cada um (muito mais do que nos diálogos), o desfecho pra minha história. ${ }^{40}$

Nesse sentido, o último capítulo de Sapato de salto, nomeado Expressões, também realiza esses enquadramentos mentais que ocorrem em Aula de inglês, remontando-se ao ato de fotografar; porém, mais que isso, esses enquadramentos demonstram uma imensa concentração de gestos em detrimento dos diálogos, o que remete a poses de fotografia:

\begin{abstract}
A princípio, nada no rosto da Sabrina se mexeu. Depois começou um movimento lento: a testa franziu; o olho se estreitou; a boca (semi-aberta e esquecida da broa que tinha parado de mastigar quando a notícia foi dada) se fechou devagar. O olho foi procurar o olho de Andrea Doria; quando encontrou ele rindo e viu a cabeça do Andrea Doria fazendo que sim, que sim, que era isso mesmo, o movimento na cara de Sabrina se acelerou: a boca mastigou a broa depressa, e mais depressa ainda engoliu; a testa se desfranziu; o olho desatou a brilhar, correu pra Paloma, brilhou ainda mais; a boca se esticou, abrindo lugar pro riso; as lágrimas foram chegando, crescendo, transbordando. ${ }^{41}$
\end{abstract}

Os enquadramentos fotográficos de cada parte do corpo das personagens são realizados verbalmente por meio da predominância de verbos transitivos diretos que têm como sujeito os olhos, a testa, a boca, ou seja, as partes do rosto de Sabrina, o que leva não só ao recorte do olhar para somente essa área do rosto, como também à intensificação do movimento de cada uma dessas partes, o que torna teatral e vívida a expressão da personagem, tal como a de uma atriz em momento de encenação.

Em Aula de inglês, esse mesmo processo está relacionado à maneira pela qual o protagonista, o Professor de inglês, percebe o mundo:

(...) Tinha lido uma entrevista de um fotógrafo famoso: a câmera era a melhor companheira dele; saíam sempre juntos e era através dela que ele via o mundo; as grandes fotos dele não tinham sido programadas: ele saia andando sem rumo, e, de repente, ele sentia que uma cena qualquer estava 'pedindo para ser fotografada'; aí começava o que ele chamava de encantamento: o enquadramento: como é que ele ia enquadrar a cena? ela toda? pela metade? só sugerida? mais sombria? mais iluminada? ${ }^{42}$

Nesse sentido, desde a capa a obra demonstra, além da relação do protagonista com a fotografia, o uso que este faz dessa arte para se relacionar com as mulheres:

\footnotetext{
${ }^{40}$ BOJUNGA, Lygia. Sapato de salto. Rio de Janeiro: Casa Lygia Bojunga, 2006, p. 255 e 256.

${ }^{41}$ Ibid. p.257-258.

${ }^{42}$ BOJUNGA, Lygia. Aula de inglês. Rio de Janeiro: Casa Lygia Bojunga, 2006, p.30.
} 
Figura 1 - Capa da obra Aula de Inglês

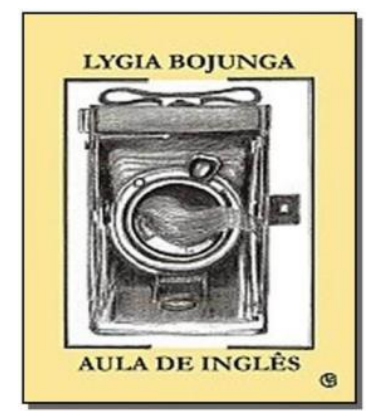

Fonte: Bojunga, Lygia (2006)

Durante a narrativa - do professor de inglês que se apaixona pela aluna Teresa Cristina e reencontra-se com seu amor de infância, Penélope, ou Tia Penny -, os diálogos entre professor e aluna são permeados por enquadramentos mentais que o protagonista faz de Teresa Cristina, tal qual uma fotografia: "Que interessante esse ângulo. Ela assim de perfil olhando a chuva lá fora. A cabeça ficou tão bem emoldurada no quadro da janela. Ia ser uma foto perfeita. Preto e branco. Até o suéter cinzento que ela resolveu botar hoje..."43

Percebe-se, portanto, que, nessa obra, não apenas as cores são retratadas, como também o ângulo e o cenário, que são algumas das preocupações de um fotógrafo, como o professor de inglês. Essa técnica da fotografia imprime à linguagem verbal maior carga de teatralidade não apenas na construção da fisionomia da personagem, mas também da posição desta em relação ao cenário.

Toda essa preocupação da personagem Professor com enquadramentos ocorre desde a primeira vez que tirou uma fotografia, que, no caso, foi de outra mulher, seu primeiro amor, tia Penny:

O cabelo da tia Penny tinha um tom avermelhado que deixava ele fascinado e que agora, espiando na lente pra enquadrar a tia Penny com arte, ele via que, mesmo contido numa trança displicente que quando já ia acabando se amarrava numa fita amarela, volta e meia um pedacinho do cabelo se soltava pra esvoaçar. (...) Foi chegando mais pra perto. A tia Penny levantou a mão querendo tirar da frente do olho o cabelo que esvoaçava. Mas continuava tão distraída, que se esqueceu de desmanchar o gesto. E a mão ficou parada no ar, mal prendendo o cabelo entre o indicador e o polegar.

Desde que a tia Penny tinha chegado o Professor alimentava o desejo de ficar um tempo imenso olhando só pra ela.(...) Ah! que maravilha essa agora: de olho ausente da tia Penny, ter ela tão presente pra olhar (...) cada dedo tinha se arrumado de um jeito feito fazendo pose pra foto que ele ia bater. Achou que parecia mais dedo de criança que de mulher. ${ }^{44}$

\footnotetext{
${ }^{43}$ BOJUNGA, Lygia. Aula de inglês. Rio de Janeiro: Casa Lygia Bojunga, 2006, p.10

${ }^{44}$ Ibid., p. 21.
} 
Nota-se que, nesse trecho, diferentemente do anterior, o narrador não é a personagem professor, mas sim um narrador em $3^{\text {a }}$ pessoa. Embora os focos narrativos sejam diferentes, a técnica do enquadramento permanece, como forma de demonstrar que, desde criança, o protagonista tem essa aptidão, ao mesmo tempo em que se descreve a personagem tia Penny peloolhar da câmera fotográfica. Esse mesmo narrador conta o momento do reencontro do Professor com tia Penny, depois que esta já é uma senhora, tomando o cuidado de fazer os mesmos enquadramentos do cabelo, dos olhos e das mãos, a fim de comprovar o tempo decorrido e o menor entusiasmo do Professor perante aquela que fora seu primeiro amor:

A mulher que entrou na sala, e que logo parou e se apoiou com as duas mãos na
bengala pra poder olhar pra ele, parecia muito velha. Magra. Curvada. Lente grossa
nos óculos. O cabelo, todo branco, preso numa trança só, meio desmanchada. A
velha senhora usava uma calça comprida escura e um suéter de lã grossa. ${ }_{45}$

A diferença das imagens enquadradas é intensificada quando o Professor vai até o quarto de Penny e vê a foto que ele havia tirado dela em sua juventude. Ele relembra a tia Penny que um dia já tinha existido, mas não existe mais. Nesse sentido,

A fotografia é uma representação do 'real' e, sendo imagem, representa algo pela sua ausência. A presença da imagem representa a ausência do objeto fotografado mas, implica na presença desse objeto em algum tempo e em um determinado lugar. ${ }^{46}$

Esse recurso da fotografia utilizado na literatura para a construção das personagens também está vinculado ao poder de demonstrar a descrição da transformação fisionômica delas, sem, no entanto, apagar a lembrança de quem foram anteriormente. Essa relação entre fotografia e memória aparecerá também em Querida.

Nesta obra, a descrição fotográfica da personagem auxilia o resgate das lembranças do narrador da trama, Pollux. Já no prólogo da obra, há um monólogo que se desencadeia a partir do contato com um obituário de jornal, onde há a foto de Ella. A descrição verbal dessa foto torna a imagem muito realista, visto que às partes que compõem o rosto são atribuídos movimentos ou características humanas:

aquele cabelo revolto, os lábios carnudos que desenhavam tão bem a boca um pouquinho só aberta, os olhos que encantavam o rosto de uma expressão

\footnotetext{
45 BOJUNGA, Lygia. Aula de inglês. Rio de Janeiro: Casa Lygia Bojunga, 2006, p. 170.

46 BOTELHO JUNIOR, Francisco Cassiano. A imagem fotográfica e o 'real'. 1981. 171.f. Dissertação (Mestrado em artes) - Escola de Comunicação de Artes, Universidade de São Paulo, São Paulo, p.108.
} 
surpreendente: convite que já antecipava rejeição; sensualismo que, paradoxalmente, era frio; espanto que era também desdém ${ }^{47}$

Essa descrição fotográfica fez Pollux se lembrar de sua infância, momento em que envolvia Ella. Nesse sentido, a fotografia foi um recurso que despertou o elo do narrador com a personagem falecida, transformando esse momento inicial da ausência da personagem em presença, seja pela fotografia, seja pelas memórias.

A obra Retratos de Carolina também caracteriza literariamente as personagens por meio de recursos da fotografia, de modo a lhes proporcionarem maior teatralidade. Percebese, desde o título, o termo retrato que significa imagem de uma pessoa real ou imaginária. Essa imagem pode ser uma pintura, um desenho ou mesmo uma fotografia, sendo este o recurso para se analisar Carolina. É importante ressaltar que o título da obra é seguido de uma espécie de subtítulo - "feitos por Lygia Bojunga" -, que, ao mesmo tempo em que apresenta o nome da autora, refere-se ao sentido metonímico do termo retratos: obra artística em que se reproduz a imagem do retrato. Tem-se, portanto, a aproximação do texto literário com a linguagem das artes plásticas.

Tendo isso em vista, na segunda parte de Retratos de Carolina, há o diálogo entre a autora e Carolina, sendo que esta reclama dos retratos negativos que foram contados sobre ela. Acerca disso, a autora - trata-se da própria Lygia Bojunga, já que essa parte da narrativa encontra-se dentro do Pra você que me lê - responde, utilizando linguagem fotográfica, neste trecho:

- Eu concordo com você, Carolina, a Priscilla e a família dela davam um monte de retratos coloridos. Mas eu estava a fim de preto e branco, o que que eu posso fazer? Estava a fim de te fazer descobrir bem cedo que amor e ódio andam assim, ó, juntinho, um do outro; 'tava a fim de te mostrar de saída a dor de uma traição. ${ }^{48}$

Não só se percebe o objetivo da autora em fazer retratos negativos de Carolina, como também o de ela utilizar a linguagem fotográfica para tornar mais expressamente imagética a construção da personagem Carolina.

Na sequência, ao fim da obra, no capítulo positivo, isto é, no retrato colorido, denominado Carolina aos vinte e nove anos, há o reencontro de Carolina com Priscilla,

47 BOJUNGA, Lygia. Querida. Rio de Janeiro: Casa Lygia Bojunga, 2009, p.10.
${ }^{48}$ BOJUNGA, Lygia. Retratos de Carolina. Rio de Janeiro: Casa Lygia Bojunga, 2002, p.166. 
momento em que já se constatam as mesmas técnicas fotográficas que Lygia Bojunga irá utilizar, posteriormente, em Aula de inglês e em Sapato de salto:

Carolina olhou pra moça.

Lá pelas tantas a moça olhou pra Carolina,

Ficaram se olhando por um momento. Desviaram o olhar.

Depois de um tempo pequeno o olho da Carolina voltou pra moça: um jeito de olhar entre pensativo e intrigado.

O olho da moça foi voltando pra Carolina, também meio pensativo.

A testa de uma se franziu; a mão da outra pegou uma ponta de cabelo e ficou virando ele no dedo, de um jeito que a gente só vira quando está muito absorta num pensamento qualquer.

O olho de uma saiu do olho da outra. Mas não demorou muito voltou. Se afastaram outra vez.

A testa que tinha se franzido, se franziu com mais força. O dedo que virava a ponta do cabelo, virou mais rápido.

E outra vez - agora mais demorado, mais fundo - o encontro do olho de uma e de outra.

A boca da moça foi se abrindo de leve, feito coisa que queria falar, perguntar. A boca da Carolina se apertou um pouquinho. E o olho das duas, agora mostrando uma dúvida, uma certa perplexidade, saiu andando pelo chão, pelo teto, pela cara das outras pessoas que estavam no metrô. ${ }^{49}$

A descrição voltada às partes do rosto das personagens é similar à das duas outras obras em termos de fotografia, sendo, nesse caso específico, retratada a incerteza do reconhecimento de uma personagem pela outra após tantos anos de distanciamento.

Tendo em vista todos esses recursos utilizados na construção imagética da caixa cênica representada na literatura de Lygia Bojunga, passa-se às análises acerca dos recursos dos diferentes tipos de teatro recorrentes na obra da autora

${ }^{49}$ BOJUNGA, Lygia. Retratos de Carolina. Rio de Janeiro: Casa Lygia Bojunga, 2002, p.212 e 213. 
A epopeia, a poesia trágica, e também a comédia, o ditirambo, e mesmo, no que respeita ao essencial, a poesia aulética e a citarística são todas, no seu conjunto, imitações. Mas diferem uma das outras de três maneiras: ou imitam por meios diferentes, ou imitam de modos diversos e variados.

Aristóteles

Dificilmente [uma mesma pessoa] exercerá uma das profissões de importância e imitará muitas coisas e será imitador, uma vez que nem sequer as mesmas pessoas imitam bem as duas artes miméticas que parecem próximas uma da outra, a comédia e a tragédia.

(...)

- Tão-pouco se pode ser ao mesmo tempo rapsodo e actor.

Platão

Faltando o narrador, cuja função foi absorvida pelos atores transformados em personagens, a forma natural destes últimos que se envolverem em tramas variadas, de se relacionarem e de exporem de maneira compreensível uma ação complexa e profunda, é o diálogo.

Anatol Rosenfeld 


\title{
3. O DRAMA CLÁSSICO
}

\subsection{O DRAMA CLÁSSICO COMO GÊNERO LITERÁRIO}

$\mathrm{Na}$ atualidade, sabe-se que dificilmente há um gênero literário que domine toda uma obra, sem a presença de outros, como se acreditava na Grécia Antiga. Por isso, é importante saber distinguir, na teoria dos gêneros, a teoria prescritiva da descritiva:

\begin{abstract}
Qualquer um interessado na teoria dos gêneros deve ter cuidado para não confundir as diferenças distintivas entre a teoria 'clássica' e a moderna. A teoria clássica é regulamentadora e prescritiva, embora suas 'regras' não sejam o autoritarismo tolo ainda atribuído frequentemente a elas. A teoria clássica não apenas crê que um gênero difere de outro, mas também que devem ser mantidos separados, que não devem permitir que se misturem. Essa é a famosa doutrina da 'pureza do gênero'. [...] A moderna teoria dos gêneros é claramente descritiva, não limita o número de tipos possíveis e não prescreve regras aos autores. Supõe que os tipos tradicionais podem ser 'misturados' e produzir um novo tipo. ${ }^{50}$
\end{abstract}

A teoria moderna, portanto, não tem a preocupação clássica de classificar os gêneros como puros, mas de perceber os traços estilísticos de cada gênero em uma mesma obra, como recurso literário, e como isso contribui para a intencionalidade de um texto. Com base nessa ideia, focar-se-á, doravante, o drama em oposição aos demais gêneros a fim de compreender como eram definidos de acordo com a teoria clássica.

O drama é um gênero literário que se consolidou como clássico a partir do olhar dos filósofos da Antiguidade grega. Anatol Rosenfeld ${ }^{51}$ explicita a classificação dos gêneros literários feita por Platão e Aristóteles. A classificação de obras literárias, para Platão, em $A$ República, abrangia três tipos de obras: a primeira é a tragédia e a comédia, em que o poeta desaparece, e é necessária a imitação da natureza; a segunda é a lírica, em que a presença e o relato do poeta são fundamentais; a terceira é uma mescla das duas anteriores, denominada epopeia. Já Aristóteles, em Poética, afirma que a imitação pode ser dramática ou épica - esta seria a narração. Além disso, apresenta duas formas de narrar, sendo a principal diferença entre ambas o tipo de narrador que se expressa: as personagens ou o próprio poeta. Neste último caso, estar-se-ia diante de um texto lírico.

\footnotetext{
${ }^{50}$ WELLEK, René e Warren, Austin. Teoria da literatura e metodologia dos estudos literários. São Paulo: Martins Fontes, 2003, p.318.

${ }^{51}$ ROSENFELD, Anatol. O teatro épico. São Paulo: Perspectiva, 2004, p.15-38.
} 
Nota-se, desse modo que, para Aristóteles, os gêneros literários resumiam-se a três. Por isso, a ressalva que Rosenfeld faz em sua obra sobre a teoria dos gêneros é importante, pois, embora ainda haja essa concepção pura dos gêneros como forma de padronização literária, é muito difícil encontrar textos que não tenham traços de outros gêneros. Para demonstrar essa realidade, Rosenfeld, primeiramente, caracteriza cada um dos três gêneros literários:

Pertencerá à Lírica todo poema de extensão menor, na medida em que nele não se cristalizarem personagens nítidos e em que, ao contrário, uma voz central - quase sempre um 'Eu' - nele exprimir seu próprio estado de alma. Fará parte da Épica toda obra - poema ou não - de extensão maior, em que um narrador apresentará personagens envolvidos em situações e eventos. Pertencerá à Dramática toda obra dialogada em que atuarem os próprios personagens sem serem, em geral, apresentados por um narrador. ${ }^{52}$

Essa caracterização feita pelo autor baseia-se nos termos "lírico", "épico" e "dramático" como substantivos, por isso seriam gêneros puros. Porém, Rosenfeld chama a atenção para a existência desses termos como adjetivos - como exemplo disso, há a expressão "romance épico" - que funcionarão somente como traços estilísticos de uma obra, não como gênero puro. Dessa forma, é possível identificar que uma obra não é totalmente tragédia, que pode haver traços líricos ou mesmo épicos.

Essas ideias de Rosenfeld são fundamentais para o presente trabalho, na medida em que as obras de Lygia Bojunga, embora sejam romances ou novelas, apresentam, por meio de sua forma de narrar, recursos dramáticos, típicos do teatro; portanto, não podem ser definidos de acordo com a teoria clássica dos gêneros. Exemplo disso é Sapato de Salto, que é uma novela narrada tanto por meio de elementos trágicos quanto de recursos líricos, além de sua temática não ser própria do drama aristotélico.

Ademais, outra especificidade do drama clássico enquanto gênero literário é a de considerar os protagonistas na narrativa como determinantes do gênero. Segundo Wellek, a epopeia e a tragédia lidam com assuntos de reis e nobres, a comédia com as de classe média (a cidade, a burguesia), e a sátira e a farsa com pessoas comuns. ${ }^{53}$

Essa é outra razão que torna o drama em Lygia Bojunga mais afastado do drama clássico, que é pautado nos princípios aristotélicos. Nota-se que, independentemente da

\footnotetext{
${ }^{52}$ ROSENFELD, Anatol. O teatro épico. São Paulo: Perspectiva, 2004, p.17.

${ }^{53}$ WELLEK, René e WARREN, Austin. Teoria da literatura e metodologia dos estudos literários. São Paulo: Martins Fontes, 2003, p.19.
} 
abordagem da obra da autora, se mais realista (trágica) ou mais fantasista (lúdica), não há essa separação radical entre personagens oriundas de classes sociais distintas, principalmente como forma de determinar um gênero específico para a narrativa. Pelo contrário, na maioria das vezes essas personagens convivem em algum nível. Alguns exemplos dessa convivência: em Os colegas, a cadela de madame vive com os vira-latas; em A casa da madrinha, Alexandre e Vera, que são de classes sociais distintas, tornam-se colegas; em Corda bamba, os pais da protagonista são de classes sociais diferentes; em Tchau, Rodrigo e Tuca tornam-se amigos de escola, mesmo o primeiro sendo rico e o segundo morador de uma comunidade carioca.//

\subsection{O DRAMA CLÁSSICO COMO TEATRO}

Como a base para a conceituação de drama clássico é a Antiguidade grega, são essenciais as considerações de Aristóteles acerca do assunto.

Jean-Jacques Roubine ${ }^{54}$ apresenta um resumo da obra Poética de Aristóteles no que diz respeito ao drama e pormenoriza uma das regras aristotélicas: a regra unitária. Esta é baseada na necessidade de o teatro ser perfeitamente verossímil; porém, essa verossimilhança não é totalmente alcançada porque o tempo e o espaço, que são representados em uma peça, não correspondem à total realidade. Nesse sentido, a doutrina unitária tenta regular os três elementos que estruturam a peça teatral. São elas: a ação, o espaço e o tempo. Embora as três unidades dramáticas sejam importantes para a representação teatral, a questão do espaço não será abordada nessa parte da análise por dois motivos. Primeiramente, porque, de acordo com Roubine, na Poética, de Aristóteles, não há considerações do filósofo grego em relação à questão do lugar e de sua unificação. Em segundo lugar, porque o espaço, em Lygia Bojunga, muitas vezes é elemento de construção do imaginário, do maravilhoso, vertentes que não serão extremamente exploradas, por já ser um tema muito trabalhado.

A ação, nas teorias do teatro, é classificada de variadas maneiras. Por esse motivo, antes de iniciar uma contextualização sobre o assunto, é fundamental conhecer a definição tradicional de ação e pensá-la de maneira a problematizá-la, como faz o Dicionário de Teatro:

A definição tradicional de ação ('sequência de fatos e atos que constituem o assunto
de uma obra dramática ou narrativa', dicionário Robert) é puramente tautológica,
visto que se contenta em substituir 'ação' por atos e fatos, sem indicar o que
constitui esses atos e fatos e como eles são organizados no texto dramático ou no

${ }^{54}$ ROUBINE, Jean-Jacques. Introdução às grandes teorias do teatro. Rio de Janeiro: Jorge Zahar, 2003. p.27. 
palco. Dizer, com ARISTÓTELES, que a fábula é a 'junção das ações realizadas' (1450a) ainda não explica a natureza e a estrutura da ação; trata-se, em seguida, de mostrar como, no teatro, esta 'junção das ações' é estruturada, como se articula a fábula e a partir de que índices pode-se reconstituí-la. ${ }^{55}$

Dessa perspectiva, a ação está relacionada à sequência de ações, uma vez que estas são essenciais para a forma do texto e para a construção do sentido dele. Acerca dessa consideração, é interessante acompanhar a interpretação aristotélica que Roubine faz sobre a ação a partir do seguinte trecho de Poética, de Aristóteles: “A fábula, que é representação da ação, deve sê-lo de uma ação unida e que forme um todo; e as partes que constituem os fatos devem ser ordenadas de maneira que, se uma delas for deslocada ou suprimida, o todo seja deslocado e abalado".

Dessa maneira, a ação, na visão aristotélica, é formada de partes que constituem o sentido da obra. Por isso, se alguma dessas partes for retirada da obra ou negligenciada, a coerência dela é extremamente prejudicada. Nesse sentido, Roubine chama a atenção para a "coerência orgânica" das cenas:

Para Aristóteles, a unidade de ação não se define pela unicidade, mas pela coerência orgânica. Os acontecimentos representados ou relatados podem ser numerosos. Devem ser ligados uns aos outros por um elo de necessidade e, explicitamente, concorrer para o desenlace da ação. ${ }^{56}$

A "coerência orgânica" é o que resulta no sentido da ação como um todo, é como a leitura de todas as ações, sejam elas principais ou secundárias na narrativa, juntam-se em prol de constituir o sentido da obra.

Nesse contexto, pode-se dizer que as obras de Lygia Bojunga conseguem, com muito sucesso, estabelecer essa coerência orgânica. Seguem-se alguns exemplos:

Em A casa da madrinha, o recurso literário da multiplicidade de narradores que contam as suas próprias histórias, como o Pavão e a Gata-da-Capa, contribuem para o sentido da narração principal - a de Alexandre -, já que, quando o garoto chega à casa da madrinha, mesmo que pela imaginação, todos os sonhos dessas personagens são realizados. Se não houvesse essas narrativas paralelas, a coerência orgânica - ou seja, o sentido estabelecido pela união das partes da narrativa - seria prejudicada.

\footnotetext{
${ }^{55}$ PAVIS, Patrice. Dicionário de teatro. São Paulo: Perspectiva, 2015, p.2.

${ }^{56}$ Apud ROUBINE, Jean-Jacques. Introdução às grandes teorias do teatro. Rio de Janeiro: Jorge Zahar, 2003, p. 42.
} 
Em Fazendo Ana Paz, Lygia Bojunga, ao escrever o processo de criação da personagem Ana Paz, acaba criando cenas com personagens distintas: A Ana Paz, a moçaapaixonada-pelo-Antonio e uma senhora. Aparentemente essas personagens não apresentam nenhuma relação, o que a própria autora sugere, ao dizer que tenta desenvolver a história de Ana Paz, mas são outras personagens que aparecem em sua escrita. Porém, as três personagens e suas respectivas narrativas são interconectadas, resultando na história de Ana Paz, como será analisado no capítulo acerca do Metateatro.

Em Paisagem, há narrativas dentro de narrativas: a principal é a de Lourenço e de uma personagem-autora, leitor e escritora, respectivamente, que trocam correspondências e acabam se conhecendo e tentando decifrar juntos o mistério da Paisagem sobre a qual Lygia escreve em um conto, intitulado de Paisagem, conto este também presente na obra, como narrativa à parte da central. As escolhas narrativas de Lygia Bojunga, personagem-autora da obra, mudam a narrativa central, já que a escritora transfere personagens de uma história para outra. Dessa forma, por mais que exista mais de uma narrativa na obra, todas elas têm coerência entre si.

Em Retratos de Carolina, cada capítulo é um retrato da protagonista em uma idade. Desde o primeiro retrato, há indícios dos assuntos que serão posteriormente abordados na narrativa, como a liberdade feminina, as amizades de infância desfeitas, a busca pelo Homem Certo e a falta de compreensão da mãe.

Já em Sapato de Salto, o enredo é cronológico, porém a descrição da vida de cada personagem, abordada pelos capítulos com os seus respectivos nomes, poderia ser lida de maneira independente do todo. Entretanto, a ordem desses capítulos, mesmo apresentando as personagens que, aparentemente não terão vínculo - como a família de Paloma e Sabrina proporciona sentido para a história, sentido este que é percebido com mais clareza ao fim do romance, momento em que as histórias se relacionam.

Portanto, nota-se que a obra bojunguiana é baseada em grande preocupação com a concatenação das partes do todo, para que a narrativa central tenha sentido a partir de detalhes que vão constituindo o caminho do fio narrativo.

Essa coerência orgânica, em algumas obras de Bojunga, parte da ação repetitiva de algumas personagens, como é o caso, em $O$ sofá estampado, de Vítor, o tatu que cava intensamente diante de situações de nervosismo; em A bolsa amarela, de Raquel, que guarda 
seus medos e segredos na bolsa e, em Corda bamba, a protagonista Maria que transita entre o apartamento da avó e o universo lúdico. A repetição dessas ações não apenas ajuda a expor os problemas pelos quais as personagens passam, como também serve de fio condutor para o desenvolvimento de outras ações e, portanto, da narrativa.

Outrossim, as ações iniciais, sobretudo nas últimas obras da autora, mostram personagens que, posteriormente, terão outra visão de mundo, como acontece com Carolina, de Retratos de Carolina, ou outro rumo de vida, como ocorre com Teresa Cristina, em Aulas de inglês, e com Paloma e Sabrina, de Sapato de salto. Assim sendo, as ações vão transformando as personagens e os seus destinos.

Acerca do tempo como elemento estruturante da peça teatral, é importante recuperar a visão aristotélica. Nessa visão, há a preocupação com a verossimilhança das obras, por isso a mimese da natureza é um fator primordial para que a perfeição da obra fosse alcançada. Entretanto, o tempo na representação de uma peça pode ser um problema. Uma vez que o tempo de uma determinada atividade não corresponde ao tempo de sua representação, a verossimilhança não é construída perfeitamente. Nesse sentido, essa unidade, de acordo com a teoria clássica, deve ser respeitada sem haver grandes discrepâncias entre o tempo que corresponde a plena duração de uma ação e o tempo que representa essa ação ou sequência de ações. Essa visão clássica do tempo teatral não pode ser aplicada às obras de Lygia Bojunga, visto que cada uma destas apresenta um modo por meio do qual o tempo transcorre, sem que a verossimilhança seja afetada.

Nas primeiras obras de Lygia, o tempo, como unidade constituinte da verossimilhança, não é um fator tão importante, pois as temáticas menos sociais e o universo lúdico construído neles permitem o foco da obra na ação, não no tempo.

Como ilustração, pode-se citar a obra pioneira de Lygia Bojunga, Os colegas, que já apresenta a demarcação do tempo nos capítulos, registrado nos títulos destes que indicam o período anterior e posterior ao Carnaval. Outra obra em que o tempo não tem papel fundamental é Livro - um encontro, já que se trata de uma perspectiva teatral, de um monólogo, forma essa que trabalha com tempo psicológico, não demarcado. Entretanto, algumas obras, como Retratos de Carolina, precisam do elemento tempo como fio condutor da narrativa, sendo esta cronológica, e, nesse caso, organizada por meio de "retratos" da protagonista de acordo com a idade que ela tem, como já indicado nos títulos: "Carolina aos seis anos", "Carolina aos quinze anos", "Carolina aos vinte anos", assim por diante. 
A exemplo de outra obra em que o elemento tempo é bem demarcado, tem-se Tchau, visto que o termo que dá título à obra indica uma despedida, uma marca temporal, que, em muitos casos, levará a mudanças significativas para quem se despede e/ou para quem recebe a despedida. Assim, o tempo decorrido é marcado por meio da maneira pela qual os contos são organizados. No caso do primeiro conto, Tchau, há minicapítulos, cujos títulos já indicam momentos específicos da narrativa: "O buquê", "No sofá da sala", "Na mesa do botequim", "A mala", "O pai volta tarde e encontra um bilhete no travesseiro". Cada minicapítulo aborda um tempo diferente, transcorrido. No conto $O$ bife e a pipoca, o tempo é marcado pelas cartas que são enviadas por Rodrigo a um amigo que se mudou. Nessas correspondências, o menino resume o conteúdo da narrativa que se segue. É interessante notar que, para que se preste atenção no conteúdo da carta, não em quanto tempo foi decorrido, a estrutura desse gênero textual é mantida, com exceção do cabeçalho, que é o que justamente mostra a data exata em que a personagem estaria escrevendo. No lugar do cabeçalho, a autora coloca "Carta ao amigo", exceto na última parte do conto, em que Rodrigo escreve apenas um "Bilhete e PS de amigo". No conto A troca e a tarefa, as letras capitais no começo dos parágrafos indicam uma nova parte do conto que, na maior parte das vezes, faz menção a um tempo diferente do da parte anterior: "Eu tinha 9 anos quando a gente se encontrou, o Ciúme e eu" "57; "Fui crescendo. E cada ano que passava, o Ciúme aparecia mais vezes pra ver" ${ }^{\circ 3}$ "“Um dia (era férias) em frente da nossa casa veio morar um rapaz chamado Omar." "59; "Minha irmã tinha se casado." "60; "Os anos foram passando."61 "O último capítulo do meu livro, o lápis, o apontador - ficou tudo como eu deixei há cinco anos."62; "Tempos atrás eu comecei a escrever essas anotações." "63; "Há seis meses que eu não abria esse caderno, não pegava um lápis". 64

Da mesma maneira, o tempo é um fator importante em obras como Sapato de Salto, cujas temáticas são mais sociais, cujos destinos das personagens, em virtude dessas temáticas, são mais dúbios, visto que a narrativa é constituída de ações que se passam em períodos bem distintos, não ocorre como nas obras iniciais da autora em que há a impressão de um presentismo constante.

\footnotetext{
${ }^{57}$ BOJUNGA, Lygia. Tchau. 19. ed. Rio de Janeiro: Casa Lygia Bojunga, 2012, p.89.

${ }^{58}$ Ibid., p. 91 .

${ }^{59}$ Ibid., p. 92 .

${ }^{60}$ Ibid., p. 100 .

${ }^{61}$ Ibid., p.102.

${ }^{62}$ Ibid., p. 108 .

${ }^{63}$ Ibid., p. 109 .

${ }^{64}$ Ibid., p.109.
} 
Por essa razão, no primeiro capítulo dessa obra, por exemplo, percebe-se o passar do tempo pela intensificação gradual das cenas. Primeiramente, Sabrina chega à casa da família para ser somente babá. Porém, a menina começa a ter outras funções domésticas, o que caracteriza a exploração do trabalho infantil. Essa exploração passa a ser mais intensa, após Matilde descobrir que o marido dela tem relações sexuais com a menor. A intensidade da exploração resulta no cansaço da menina, que dorme no horário de trabalho e é agredida fisicamente pela patroa. Em segundo lugar, há a intensificação também em relação às expectativas da menina em ter uma família, as expectativas sexuais de Seu Gonçalves em relação à Sabrina e a intensificação do resultado de ambas as expectativas. Nota-se, ao longo desse capítulo, que Sabrina tem apreço pelas crianças de quem cuida, que gostaria de chamar D. Matilde de tia ou de mãe. Entretanto, é sempre rejeitada pela patroa. Apesar dessa rejeição, começa a pensar em Seu Gonçalves como um pai, já que ele passa a dar presentes para ela e sempre a defende dos maus-tratos da esposa. Com isso, Sabrina passa a ter expectativas de que terá um pai.

As expectativas de Seu Gonçalves também foram aumentando, porém as dele estavam pautadas no desejo de abusar sexualmente da menor. Logo no começo da obra, nota-se que ele defende a garota das reclamações da esposa; depois, ele passa a olhar a calcinha de Sabrina enquanto ela brinca com os filhos dele; posteriormente, a aproximação dele em relação à garota passa a acontecer por meio de presentes e até mesmo de aulas.

Primeiramente, esses presentes são menores, como doces, depois vão ficando mais caros que os primeiros e mais adultos: calcinhas de renda e dinheiro. Quando chegam a ser estes últimos, a relação entre Sabrina e Seu Gonçalves transforma-se para ambos os envolvidos: a relação real que tinham antes dos estupros altera-se baseada na representação que cada personagem quer que o outro assuma. A representação de pai que a menina tinha em mente foi substituída pela relação com um homem que a tratava de maneira adúltera de modo a desrespeitar a esposa, o que leva Sabrina a concentrar sua atenção, durante o ato de violência praticado contra ela, muito mais no medo de a dona da casa descobrir o problema e mandá-la embora, do que no trauma pelo qual pode estar passando. Já a representação real que Seu Gonçalves tinha de Sabrina, como garota que cuida da casa e dos filhos dele, transforma-se na concretização do desejo de ela se tornar amante dele.

O resultado da realização das expectativas do marido de D. Matilde e da quebra das expectativas de Sabrina é a exploração sexual da menina que aprende que, em troca de sexo, pode ganhar o que quiser, inclusive dinheiro. A gradação de cada uma dessas expectativas é um dos modos de marcar o passar do tempo nesse primeiro capítulo da narrativa. 
Com base na relação entre ação e tempo, tão importante no Teatro Clássico e na literatura, passa-se a destacar alguns recursos do teatro, responsáveis pela construção do discurso teatral, discurso este presente na obra de Lygia Bojunga e que auxilia o desenvolvimento da ação.

Considerando que a ação e o transcorrer do tempo são construídos imageticamente pela autora, muitas vezes, por meio do diálogo, é fundamental analisar o discurso teatral.

\subsection{DISCURSO TEATRAL}

O termo discurso teatral não será conceituado de maneira diferente ao termo discurso da Linguística:

Por uma transferência de metodologia - ou em certos casos, simplesmente de
vocabulário - o discurso e sua problemática invadiram a crítica teatral. Fala-se de
discurso da encenação ou de discurso das personagens. (...) Na origem, o discurso é
oral, porém pode ainda ser considerado sob a forma escrita, pois o discurso 'é
também a massa dos escritos que produzem discursos orais ou que deles empresta o
contorno e os fins: correspondências, memórias, teatro, obras didáticas - em resumo,
todos os gêneros nos quais alguém se dirige a alguém, se enuncia como locutor e
organiza aquilo que diz na categoria de pessoa' (BENVENISTE, 1966:242).
Portanto, pode-se falar em discurso teatral tanto para a representação quanto para o
texto dramático, o qual está à espera de uma enunciação cênica. (...) entende-se por
discurso, com M. ISSACHAROFF, 'aquilo que singulariza o uso teatral da
linguagem, a partir dos enunciados (sua dimensão verbal) até o não-verbal (sua
dimensão visual: gestos, mímicas, movimentos, figurinos, corpos, acessórios,
cenários). ${ }^{65}$

A forma pela qual os discursos das personagens são constituídos e articulados no teatro ajuda não apenas a compreender a cena desenvolvida, como também a torná-la performática. Nesse sentido, os vários tipos de linguagem usados no palco para auxiliar a construção da ação são de extrema importância para a construção do discurso teatral:

No teatro, a ação não é um simples caso de movimento ou de agitação cênica perceptível. Ela se situa também, e para a tragédia clássica, sobretudo, no interior da personagem em sua evolução, suas decisões, logo, em seus discursos. Daí o termo ação falada.

Toda fala no placo é atuante e aí, mais que em qualquer lugar, 'dizer é fazer'. [...] Todo homem de teatro sabe bem, como SARTRE, 'que a linguagem é ação, que há uma linguagem particular no teatro e que esta linguagem jamais deve ser descritiva [...] que a linguagem é um momento da ação, como na vida, e que ela é feita unicamente para dar ordens, proibir coisas, expor, sob forma de argumentações, os sentimentos, para defender, convencer ou acusar, para manifestar decisões, para duelos verbais, recusas, confissões, etc; em suma, sempre em ato'.

\footnotetext{
${ }^{65}$ PAVIS, Patrice. Dicionário de teatro. São Paulo: Perspectiva, 2015, p. 102.
} 
Por causa destas certezas, a pragmática encara o diálogo e o acontecimento cênico como ações performáticas e como um jogo sobre os pressupostos e o implícito da conversação; em suma, como uma maneira de agir sobre o mundo pelo uso da palavra. ${ }^{66}$

A linguagem no teatro, sendo ação, não é meramente descrição da realidade. Logo, a linguagem adquire caráter performático, o que pode ser amplamente percebido nos discursos teatrais. Os discursos das personagens da literatura de Lygia Bojunga seguem por esse caminho da linguagem que demonstra ações e, por sua vez, não é composta somente pelas falas, mas também pelas informações que levam em consideração a presença do espectador da peça (ou leitor do livro). Essas informações, importantes para a construção imagética da ação, são passadas ao espectador por meio dos diálogos, dos gestos e da enunciação, envolvidos na formação do discurso, como será detalhado a seguir.

\subsubsection{Diálogos}

A primeira definição que se usará para diálogo é a que está presente na obra Teatro épico de Anatol Rosenfeld, que considera o diálogo parte da Dramática e recurso literário para estabelecer um conflito, incentivando, assim, o desenrolar da ação:

É com efeito o diálogo que constitui a Dramática como literatura e como teatro declamado [...] O que se chama, em sentido estilístico 'dramático', refere-se particularmente ao entrechoque de vontades e à tenção criada por um diálogo através do qual se externam concepções e objetivos contrários, produzindo o conflito. ${ }^{67}$

A segunda definição usada para o termo "diálogo" é de orientação linguística. Na obra Semiologia do teatro, o diálogo é definido da seguinte forma:

Do ponto de vista linguístico, [diálogo] é um dos dois padrões básicos da elocução, oposto do monólogo. Por monólogo não queremos dizer, é claro, o monólogo dramático, mas uma proferição que, embora dirigida a um ouvinte, encontra-se em sua continuação em grande parte livre de uma consideração pela reação imediata deste e de um estreito vínculo com a situação espacial e temporal efetiva em que se acham os participantes da proferição. ${ }^{68}$

Assim, percebe-se que o texto teatral, dialogado, considera a existência de seu receptor, que é a audiência:

\footnotetext{
${ }^{66}$ UBERSFELD, Anne. Para ler o teatro. São Paulo: Perspectiva, 2005, p. 6.

${ }^{67}$ ROSENFELD, Anatol. O teatro épico. São Paulo: Perspectiva, 2004, p.34.

${ }^{68}$ GUINSBURG, J.; NETTO, J. Teixeira Coelho; CARDOSO, Reni Chave. Semiologia do teatro. São Paulo: Perspectiva, 2003, p.210.
} 
Isto significa que a todos os participantes diretos do diálogo acrescenta-se outro partícipe, silencioso, mas importante, pois tudo o que é dito em um diálogo dramático se orienta para ele, no sentido de afetar sua consciência [...] O diálogo

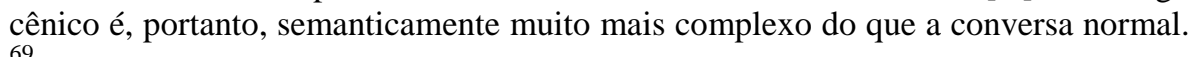

Um dos motivos dessa complexidade do diálogo acontece porque é comum que, em uma cena, a plateia (ou o leitor, no caso da leitura de textos literários compostos com elementos do teatro) saiba os objetivos de um diálogo, informação que algumas personagens podem não ter previamente.

Em algumas obras de Bojunga, é comum que o leitor vá descobrindo os detalhes da trama junto com as demais personagens da história, como acontece em A casa da madrinha. A multiplicidade de narradores pemite ao leitor que conheça a história de cada personagem, ao mesmo tempo em que a personagem Vera, que, por sua vez, toma conhecimento de todas as narrativas via diálogo com Alexandre. Já em Sapato de Salto, o diálogo vai indicando o que ocorrerá na história, e há "pistas" para que o leitor faça inferências. A exemplo disso, no núcleo dramático referente à família de Paloma, já há indícios de que o relacionamento familiar entre o homem da casa e os demais integrantes da família é difícil. Esses indícios baseiam-se em várias motivações, dentre elas: o machismo e a homofobia do marido de Paloma (Rodolfo); a não superação do casal referente à perda de uma filha; os interesses de Paloma conflitantes aos de Rodolfo; a maneira como Paloma trata a opção sexual de seu filho (Andrea Doria) que destoa da maneira de Rodolfo; a culpa que Rodolfo atribui a Paloma pelo comportamento homoafetivo do filho, entre vários outros indícios. Quando o casal separa-se, portanto, não há muita surpresa, visto que as condições propícias a esse acontecimento já tinham sido declaradas ao leitor anteriormente. Logo, essas pistas deixadas ao longo da história, por meio de diálogos, mostram a preocupação com um interlocutor que participa da história, mesmo que não tenha voz na obra a que está tendo acesso, mesmo que seja um partícipe silencioso.

Em Bojunga, essa participação silenciosa do leitor ocorre não somente por meio desses indícios que preveem o desfecho da narrativa, mas também pelo espaço que a autora criou em suas obras, denominado Pra você que me lê. É um espaço que faz parte do livro e funciona como uma espécie de longo monólogo metalinguístico que informa ao leitor os processos de criação ou os sentimentos da autora em relação àquela obra que está sendo lida.

\footnotetext{
${ }^{69}$ GUINSBURG, J.; NETTO, J. Teixeira Coelho; CARDOSO, Reni Chave. Semiologia do teatro. São Paulo: Perspectiva, 2003, p.211.
} 
Assim sendo, Pra você que me lê pode ser apresentado no início (prefácio), no meio (capítulo) ou no fim da narrativa (posfácio). O tom de conversa com o leitor que Bojunga atribui a esse texto é outra forma de diálogo, recurso essencial do teatro, presente nas obras bojunguianas, sobretudo em Intramuros, que é um Pra você que me lê que se tornou obra literária.

Na literatura de Lygia Bojunga Nunes, é extremamente marcante também a utilização dos diálogos entre as personagens, assemelhando-se a atores que contracenam em um palco de tão vívidos que são os diálogos, inclusive entre personagens que foram criadas por personagens-autora. Um dos recursos que permite a verossimilhança nesses casos é a escolha do foco narrativo, se um narrador onisciente, insciente, personagem, observador ou até mesmo autor. Esses narradores podem se tornar mais ou menos ausentes, mas, em algumas obras, como Retratos de Carolina ou Intramuros, Bojunga reduz a interferência do narradorautor para que suas personagens possam se expressar de modo mais autônomo, embora saibase, ao fim de ambas as obras, que esse narrador-personagem, que também dialoga com suas próprias personagens, é quem define os enredos e os finais das narrativa, pois se trata de um personagem-autor.

Considerando a autonomia das personagens, pode-se dizer que o diálogo é:

Técnica peculiar à linguagem teatral, é das formas narrativas que dão mais objetividade às personagens e situações, pois é a que mais se aproxima da vida real daí ser uma das técnicas mais ricas para a caracterização das personagens. É a oportunidade que o autor dá a elas de se revelarem diretamente ao leitor, eliminando a mediação do narrador. ${ }^{70}$

Nesse sentido, como Lygia Bojunga escreve de maneira teatralizada, todas as relações entre as personagens de sua obra, que resultam nas ações que constituem a narrativa, são mostradas por intermédio de diferentes tipos de personagens que dialogam e de diferentes durações (extensões) de diálogos: entre animais, entre objetos, entre humanos e animais, entre humanos e objetos, entre autora e personagens, entre personagens e leitor. O diálogo é a base de todas as obras, sendo que as primeiras têm diálogos mais curtos, mais diretos, ao passo que as últimas apresentam diálogos maiores, por causa da densidade dos assuntos, como em Aula de Inglês e Retratos de Carolina.

\footnotetext{
${ }^{70}$ COELHO, Nelly Novaes. A literatura infantil: história, teoria, análise: das origens orientais ao Brasil de hoje. São Paulo: Quíron, 1981, p.71.
} 
O diálogo não é o único recurso do discurso teatral, que ajuda a construção da ação e da vivacidade das cenas. Juntamente a ele, há outra forma de linguagem que o complementa ou mesmo o substitui: o gesto.

\subsubsection{Gestos}

Parte-se da definição de gestos para o teatro: "Movimento corporal, na maior parte dos casos voluntário e controlado pelo ator, produzido com vista a uma significação mais ou menos dependente do texto dito, ou completamente autônomo." ${ }^{, 71}$

Entretanto, é importante relacionar essa definição à conceituação relacionada às artes: “(...) é indispensável vê-lo sempre como expressão: aí está sua função primitiva e, por esta atribuição estabelecida pelas leis da natureza, é que ele embeleza a arte da qual ele é o todo, e à qual se une para tornar sua parte principal." 72

Nessa percepção, o gesto, nas artes, não apenas expressa, como também embeleza a arte e faz parte dela. Nos fragmentos da obra de Bojunga a serem analisados, essa relação será percebida.

Já Raymond Williams, ao diferenciar os quatro tipos da ação dramática - a fala encenada, a representação visual, a atividade e o comportamento -, relaciona a fala e o gesto:

Nenhuma ação significante é separada das palavras - 'a poesia é a ação'. A ação é
necessariamente a unidade de fala e movimento - 'fala encenada' $[.$.$] A$
representação visual é o tipo de ação desenvolvida a partir daqueles gestos menores
que fazem parte da fala encenada. Aqui, uma ação prescrita com exatidão pela forma
literária, mas não diretamente acompanhada pela fala, é representada
separadamente.

Em algumas obras de Bojunga, é possível verificar a narração construída de modo gestual. Em Sapato de salto, por exemplo, a cena trágica do assassinato da Tia Inês é narrada, não dialogada, pois o enfoque da ação, nesse caso, deve estar sobre o movimento das personagens, não em suas falas. O narrador constrói uma linguagem visual que faz o leitor ver a cena ao lê-la, cena essa teatral, dramática e extremamente gestual:

\footnotetext{
${ }^{71}$ PAVIS, Patrice. Dicionário de teatro. São Paulo: Perspectiva, 2015, p.184.

${ }^{72}$ Ibid., p.184.

${ }^{73}$ WILLIAMS, Raymond. Drama em cena. São Paulo: Cosac-Naify, 2010, p.215.
} 


\begin{abstract}
A Tia Inês se levantou do chão, afastou Sabrina com o braço e enfiou a mão no bolso de dentro do paletó do Assassino, onde tantas e tantas vezes ela tinha visto a pistola que morava ali. Dirigiu a arma para ele, ao mesmo tempo em que dona Gracinha baixava a pedra outra vez. Num gesto rápido, o Assassino agarrou a mão que segurava a arma, desviou ela pra tia Inês e, de dedo comandando o gatilho, disparou uma, duas, três vezes.

Durante um momento os quatro ficaram imóveis. Olho dilatado.

Depois, foi tudo escorregando na tia Inês: o dedo pra fora do gatilho, a pálpebra pra cima do olho, o corpo pro chão. Foi o corpo cair que o Assassino correu pra porta. Sumiu lá fora.

Agora, as três estão ali paradas. Uma, pra sempre. As outras duas, que tinham recuado com os disparos, parecem estátuas; só o olho acompanha o sangue que vai escorrendo, escorregando do peito da tia Inês pro chão. ${ }^{74}$
\end{abstract}

Os gestos permeiam toda a cena, o que pode ser percebido, literariamente, por exemplo, na escolha da palavra "gesto", que aparece explicitamente quando o Assassino retira a arma da mão de Tia Inês e há uma sequência de verbos de ação que, com a gradação entre esses verbos, passa a noção de passo a passo dos movimentos do Assassino: "agarrou", "desviou" e "disparou". Em seguida, a imobilidade marca o resultado do assassinato, imobilidade essa também gestual. Passado esse rápido momento, a narração é focada nos gestos do corpo de tia Inês, que, por estar morrendo, perde as forças e tende a cair no chão. Nesse caso, como houve a morte, o verbo de ação "escorregar" fica subentendido na enumeração, que é composta somente de substantivos, nesse caso, as partes do corpo já sem vida, e, por isso, sem ênfase em verbos de ação: o dedo pra fora do gatilho, a pálpebra pra cima do olho, o corpo pro chão. O leitor consegue, novamente, imaginar passo a passo esses movimentos da cena, por meio da voz do narrador. Nesse sentido, o gesto, nessa cena, substitui a fala, os diálogos e, apesar de o som do disparo não existir, o que permanece é o silêncio, que é preenchido pelo gesto do "olhar" que acompanha o sangue da vítima.

Em Semiologia do teatro, esses gestos são classificados como metalinguísticos, uma vez que substituem a fala no drama, em situações em que a fala não pode ser utilizada. Na mesma obra, Guinsburg define o termo "postura", que pode ser percebido como linguagem teatral e aplicável à cena descrita acima: “A postura caracteriza-se por ser estática e por ser global, isto é: não há posturas de partes; há postura do corpo. [...] A postura é a base sobre a qual vão aparecer os gestos e os movimentos". ${ }^{75}$

Quando todas as personagens ficam imóveis, há, na cena, somente a postura dos corpos, que serão preparados para os movimentos: o do Assassino de fugir, a de Sabrina de se

\footnotetext{
${ }_{74}^{74}$ BOJUNGA, Lygia. Sapato de salto. Rio de Janeiro: Casa Lygia Bojunga, 2006, p.139.

${ }^{75}$ GUINSBURG, J.; NETTO, J. Teixeira Coelho; CARDOSO, Reni Chave Semiologia do teatro. São Paulo: Perspectiva, 2003, p.252.
} 
ajoelhar perto do corpo da tia e pedir para que ela não morra; a de dona Gracinha de pedir para a neta ajudar Inês.

Outros exemplos de gestos metalinguísticos ocorrem em Tchau, no conto que dá o nome à obra, no momento em que a Mãe de Rebeca recebe flores, que, supostamente, não são do pai da menina:

Rebeca ficou parada.

A Mãe olhou para ela; parou também: assim: meio abraçada com o buquê.

E durante um tempo as duas ficaram se olhando.

Rebeca então foi indo distraída pra cozinha.

A Mãe (distraída também) pegou um vaso, encheu de água.

E as duas arrumaram as flores devagar, sem falar nada; sem nem levantar o olho do vaso. ${ }^{76}$

Esse trecho demonstra o silêncio que ocorre entre as duas, ou seja, só poderia ser representado, teatralmente, na literatura, por meio da descrição dos gestos das personagens, que são narrados por um narrador observador.

Acontece o mesmo recurso nessa mesma obra, no conto $O$ bife e a pipoca; há uma cena em que Tuca, menino bolsista de uma escola particular, fica encabulado:

Foi só a turma rir que o Tuca se encolheu de novo; encerrou o cotovelo na carteira, botou a cara na mão, grudou o olho no caderno aberto e ficou achando que a classe tinha rido era do nome dele.

Quando a aula acabou, todo mundo saiu pro recreio, mas o Tuca nem se mexeu. ${ }^{77}$

A fim de demonstrar o encabulamento, há a enumeração de gestos, que são seguidos de uma "postura", no caso: a falta de mobilidade.

Ainda sobre gestos narrados, em Aula de inglês, o reencontro do Professor com o seu primeiro amor, no momento uma mulher muito idosa, é pautado tanto pelos gestos de carinho demonstrados pelo contato com as mãos, quanto pelas diferenças etárias que são demonstradas por gestos de apoio corporal:

O Professor ficou parado um tempo antes de perguntar:

- Tia Penny?

Uma expressão admirada foi aparecendo no rosto dela.

- Lembra do seu aluno brasileiro? - perguntou em português.

A tia Penny chegou mais pra perto. Estendeu o braço até encontrar apoio na mão do Professor. O rosto foi anunciando um riso:

- O Aluno? O Aluno? - ela perguntava. E chegava ainda mais pra perto querendo ver bem o Professor. Quando afinal se convenceu de que era ele mesmo, o riso sacudiu ela toda. - Aluno! - Aluno! - ela repetia. E ficaram assim de mãos dadas,

\footnotetext{
${ }^{76}$ BOJUNGA, Lygia. Tchau. 19. ed. Rio de Janeiro: Casa Lygia Bojunga, 2012, p.22.

${ }^{77}$ Ibid., p.49.
} 
apertadas; a tia Penny se comovendo com as ondas de lembrança que batiam na memória; a cada nova onda a mão dela sacudia a mão do Professor.

(...)

Desta vez o Professor se impressionou com a dificuldade com que a tia Penny firmava o cálice, segurando ele com as duas mãos, o corpo se vergando no esforço. Por um momento teve impressão-quase-certeza de que bastaria um abraço pro corpo dela se quebrar, tamanha a fragilidade que parecia ter. ${ }^{78}$

Dessa maneira, Bojunga elabora narrativas por meio da descrição de gestos e de posturas que auxiliam a expressividade de um sentimento e de uma reação corporal diante de uma situação específica na narrativa. Além da expressividade, o gesto agrega à teatralidade literária da autora, tornando sua literatura mais realista e, ao mesmo tempo, mais bela.

\title{
3.3.3. Enunciação
}

Outro aspecto que contribui com a constituição do discurso teatral são as funções importantes das palavras no teatro. Em Semiologia do teatro, há o conceito de enunciação que pode ser relacionado ao desenvolvimento da ação dramática:

\begin{abstract}
A enunciação de cada palavra, de cada frase, torna-se logo um processo que se desenvolve neste universo [espetáculo teatral] e, em especial, uma parte do comportamento da personagem representada [...] [Outra] função essencial das palavras pronunciadas é a de exprimir as vivências, os diferentes estados e processos psíquicos vividos pela personagem que fala neste momento. ${ }^{79}$
\end{abstract}

Desse modo, a enunciação não apenas demonstra e desenvolve o comportamento das personagens como também mostra as experiências vividas por elas. Aplicando essas funções da enunciação do teatro tanto às obras literárias mais adultas quanto às mais lúdicas de Bojunga, nota-se que a enunciação literária, sobretudo das vozes das personagens, demonstra o comportamento de cada uma delas, tornando possível, por exemplo, identificar características singulares das personagens, como em D. Gracinha, de Sapato de salto, que apresenta problemas mentais devido às decepções pelas quais passou na vida; ou como em Alexandre, de A casa da madrinha, que é obstinado, não desiste de encontrar a casa da madrinha, não importando o que digam a ele sobre essa obsessão; ou como em Vítor, de $O$ sofá estampado, que, ao ficar nervoso, passa a cavar túneis como forma de fuga da realidade.

\footnotetext{
${ }^{78}$ BOJUNGA, Lygia. Aula de inglês. Rio de Janeiro: Casa Lygia Bojunga, 2006, p. 170-187.

${ }^{79}$ GUINSBURG, J.; NETTO, J. Teixeira Coelho; CARDOSO, Reni Chave. Semiologia do teatro. São Paulo: Perspectiva, 2003, p.153.
} 
A enunciação também é construída por meio das falas que as personagens usam em muitas obras bojunguianas, pois o modo como as personagens narram uma história leva à percepção de seu comportamento. Como ilustração, pode-se citar $O$ abraço, obra em que a protagonista Cristina conta a violência sexual pela qual passou quando era criança e a sua experiência de reencontrar o seu estuprador. No início da obra, já se percebe que, embora o estupro seja um problema, a protagonista adia falar sobre ele, porém o tom confessional por meio do qual ela se expressa demonstra que é um assunto que a perturba:

\footnotetext{
Eu preciso te contar. Não dá mais pra ficar trancando essa coisa toda dentro de mim. Por mais que eu tenha resolvido não falar disso com ninguém, não dá mais pra ficar quieta depois do que aconteceu ontem à noite.

Deixa eu ver por onde eu começo.

Bom, acho melhor te contar de uma vez que quando eu tinha oito anos eu fui estu... não, pera aí, não: vamos deixar isso pra depois: eu ainda estou tão impressionada com o que aconteceu ontem à noite, que é melhor eu te contar primeiro da festa. Pra ver se eu esfrio, sabe, pra ver se eu me acalmo. Depois então eu te conto o resto. ${ }^{80}$
}

Cristina precisa se acalmar, porque se encontrou com o seu algoz e sentiu-se atraída sexualmente por ele, além de ter encontrado uma antiga amiga de infância que mexeu profundamente com a consciência dela. São a esses acontecimentos a que a protagonista quer chegar, não necessariamente à polêmica sobre o estupro, pois ela passa pela Síndrome de Estocolmo, que ocorre quando as vítimas desenvolvem algum tipo de afeto pelo seu agressor, possivelmente como uma maneira de bloquear o trauma e conseguir conviver com este, sem que esse problema devaste a sua vida. Pode-se perceber esse comportamento da personagem Cristina pelo modo como ela narra as suas experiências: as cenas não aparentam teor de violência, na verdade, há até certo lirismo.

Essas considerações acerca do discurso teatral e do Teatro Clássico são importantes para serem analisados os recursos do Teatro Épico presentes em algumas obras de Lygia Bojunga, visto que este teatro é estudado em contraste com aquele.

\footnotetext{
${ }^{80}$ BOJUNGA, Lygia. O abraço. 6. ed. 3. imp. Rio de Janeiro: Casa Lygia Bojunga, 2014, p.9.
} 
O teatro épico serve para elevar a emoção à razão.

Bertolt Brecht

Não faço teatro para o povo, o faço em favor do povo. Faço teatro para incomodar os que estão sossegados. Só para isso faço teatro.

Plínio Marcos

Preso à minha classe e a algumas roupas, vou de branco pela rua cizenta.

Melancolias, mercadorias, espreitam-me.

Devo seguir até o enjôo?

Posso, sem armas, revoltar-me?

Olhos sujos no relógio da torre:

Não, o tempo não chegou de completa justiça.

O tempo é ainda de fezes, maus poemas, alucinações $e$ espera.

O tempo pobre, o poeta pobre

fundem-se no mesmo impasse.

(...)

Uma flor nasceu na rua!

Passem de longe, bondes, ônibus, rio de aço do tráfego.

Uma flor ainda desbotada

ilude a polícia, rompe o asfalto.

Façam completo silêncio, paralisem os negócios,

garanto que uma flor nasceu.

Sua cor não se percebe.

Suas pétalas não se abrem.

Seu nome não está nos livros.

É feia. Mas é realmente uma flor.

(...)

É feia. Mas é uma flor. Furou o asfalto, o tédio, o nojo e o ódio.

Carlos Drummond de Andrade 


\title{
4 TEATRO ÉPICO
}

Segundo o Dicionário Houaiss, o termo épico é etimologicamente um vocábulo oriundo do latim (epicus), cujo significado é heroico ou relativo aos feitos dos heróis. As acepções da palavra épico, segundo esse dicionário são:

\begin{abstract}
Adj. 1. que relata, em versos, uma ação heroica. 2. relativo a ou próprio de epopeia ou de heróis. 3. digno de figurar em uma epopeia; que tem a dimensão dos motivos ou dos heróis da epopeia; heroico; 4 . de intensidade ou grandeza fora do comum, fantástico, desmedido, grandioso, homérico, memorável. s.m. 5. autor de epopeia, de poesia épica. ${ }^{81}$
\end{abstract}

Entretanto, segundo o Dicionário de teatro, de Patrice Pavis, o épico não se resume a um gênero, como o romance, a novela, o poema épico etc, principalmente porque, mesmo no interior do Teatro Dramático (a que Brecht opõe o Teatro Épico), o épico pode dar sua contribuição por meio de relatos, descrições ou comentários do narrador. Por esse motivo, o épico pode estar contido nos demais gêneros. A exemplo disso, podem-se citar peças gregas em que o coro tem o papel de ampliar a situação vista na peça, por meio de comentários.

Também preocupado com possíveis confusões, Anatol Rosenfeld procura conceituar o Teatro Épico por meio da distinção entre esse tipo específico de arte e o termo "épico":

O termo 'teatro épico' vem sendo usado desde a década de 1920, depois de ter sido introduzido pelo diretor teatral Erwin Piscator (1893-1966) e por Bertolt Brecht (1898-1956). A palavra 'épico' é usada na sua acepção técnica, significando 'narrativo', que não deve ser confundida com a acepção popular, mais ou menos sinônima de 'epopeia', poema heróico extenso, por exemplo a Ilíada ou Os Lusíadas. O termo 'épico' refere-se a um gênero literário que abrange todas as espécies narrativas, ao lado da epopeia, do romance, da novela, do conto etc. ${ }^{82}$

Nesse sentido, o Teatro Épico é o teatro em que é predominante a narração, e, por isso, opõe-se ao Teatro Dramático:

Todas as experiências optam por contar o acontecimento, em vez de mostrá-lo: a diégese substitui a mimese, as personagens expõem os fatos, em vez de dramatizálos.

$\mathrm{O}$ teatro épico surgiu como reação às facilidades da peça bem-feita e ao fascínio catártico do público. Contudo, não está estabelecido que a oposição platônica entre mimese e diégese corresponda absolutamente a uma oposição teórica, pois a mimese nunca é uma representação direta das coisas: ela aciona inúmeros índices e signos cuja leitura linear e temporal é indispensável à constituição do sentido, de sorte que

\footnotetext{
${ }^{81}$ HOUAISS, Antonio; VILLAR, Mauro de Salles. Dicionário Houaiss da língua portuguesa. 1ed. Rio de Janeiro: Objetiva, 2009, p. 781.

${ }^{82}$ ROSENFELD, Anatol. Brecht e o teatro épico. São Paulo: Perspectiva, 2012, p. 27.
} 
a imitação direta e dramática não pode se abster de um modo de contar, e que toda apresentação mimética dramática pressupõe uma narrativização da cena. ${ }^{83}$

É importante considerar que os tipos de teatro não podem ser enquadrados fixamente em uma tabela de características, visto que, sobretudo na atualidade, os textos literários, cênicos ou não, nunca seguem um único gênero sem características de outros, embora possa se notar uma predominância destas. Por isso, o próprio Brecht acaba reconhecendo que faz mais sentido falar-se em Teatro Dialético do que em Teatro Épico, uma vez que "Teatro Dialético" é uma expressão que resolve bem a contradição entre viver (identifica-se) e interpretar (mostrar).

\subsection{CONTEXTO PRÉ- TEATRO ÉPICO: PISCATOR}

O drama burguês entra em crise, uma vez que os temas tratados por ele não correspondem aos desejos da população. Os trabalhadores menos abastados, por serem vítimas das desigualdades sociais, são assuntos recorrentes no século XX, como afirma Rosenfeld: “A crise revela-se, portanto, como contradição entre a temática épica e a tentativa de manter a forma dramática tradicional". ${ }^{84}$

Por essa razão, o drama precisou ter outra forma para abordar um novo conteúdo, como afirma Brecht: "Quando se vê que o nosso mundo atual já não se ajusta ao drama, então o drama já não se ajusta ao mundo." 85

A crise, pela qual o teatro que tratava de assuntos épicos passava, não se resumia a um país, e Brecht não vivenciou o início de tal crise, como afirma Iná Camargo Costa: "Brecht não tinha nem nascido e a crítica teatral - tanto na Alemanha, que era muito forte e continua sendo até hoje, quanto na França, que era ainda mais importante - já não sabia, desde mais ou menos 1880, como designar as peças que tratavam de assuntos épicos." 86

Uma dessas peças, em 1889, quando Brecht tinha apenas nove anos de idade, foi encenada em Berlim. O nome do grupo de teatro era Cena Livre, e os seus atores encenaram a peça Os tecelões, de Gerhart Hauptmann. O acesso à peça era gratuito, para que o público-

\footnotetext{
${ }^{83}$ PAVIS, Patrice. Dicionário de teatro. São Paulo: Perspectiva, 2015, p.30.

${ }^{84}$ ROSENFELD, Anatol. Brecht e o teatro épico. São Paulo: Perspectiva, 2012, p.151.

${ }^{85}$ Apud ROSENFELD, Anatol. Brecht e o teatro épico. São Paulo: Perspectiva, 2012, p. 147.

${ }^{86}$ COSTA, Iná. Brecht e o teatro épico. Literatura e Sociedade, v. 15, n. 13, p. 214-233, 29 jun. 2010 , p.215.
} 
alvo, no caso, os trabalhadores, tivesse condições de assisti-la, uma vez que eles não teriam recursos financeiros para frequentar alguma atividade cultural. A peça, embora seja exemplo do Teatro Naturalista, já apresentava características de Teatro Épico. Como o assunto tratado na peça era de cunho social, principalmente levando os trabalhadores a crer que eles podem fazer uma revolução e que têm forças para lutar por seus direitos, a crítica conservadora não acreditava que fosse uma boa peça de teatro, já que era bem diferente do Teatro Dramático Burguês.

Acredita-se que Bertolt Brecht tenha resolvido essa crise artística sendo o pai do Teatro Épico, porém, na Alemanha do século XX, mais precisamente com o início da Primeira Guerra Mundial, antes mesmo da dedicação de Brecht à sua nova concepção de teatro, a Alemanha já apresentava teatros políticos, que, em sua essência, eram chamados de Teatro Épico:

\begin{abstract}
Brecht não é sinônimo de teatro épico. Quando Brecht chegou a Berlim, esse ponto também já estava resolvido. Chamar de teatro épico um tipo determinado de teatro que se fazia na Alemanha também já estava, não na boca de todo mundo, mas pelo menos a turma dele (Piscator, Döblin) já chamava o teatro político de épico. Simplesmente porque a esfera do político é a esfera do épico e o teatro que trata diretamente de assuntos políticos é teatro épico. Tão simples assim. ${ }^{87}$
\end{abstract}

Com essa simplicidade, já se esboçava um teatro renovado, cujos temas não somente cabiam na nova estrutura e forma teatrais, mas também a fortificavam. Um dos grandes nomes que antecedia Brecht no que se concerne ao Teatro Épico, embora tenha sido contemporâneo de Bertolt Brecht, foi Erwin Friedrich Maximilian, mais conhecido como Piscator.

Piscator foi um importante diretor alemão de teatro no século XX e foi considerado o criador do Teatro Político e do Teatro Didático, sendo o primeiro deles, posteriormente, rotulado como Teatro Épico. Inicialmente, o Teatro Político, que era aquele cujos temas tratavam de assuntos da vida pública e, sobretudo, de interesse dos trabalhadores, recebeu o rótulo de Teatro Épico por parte da crítica alemã conservadora que não acreditava ser o Teatro Político um tipo de teatro. Essa discussão sobre ser ou não arte aquilo que se pauta em problemas sociais, ainda nos dias de hoje, é muito acalorada, inclusive em universidades, em que muitos críticos acreditam que os problemas sociais anulam a arte, sendo, portanto, dois pontos que jamais coexistirão.

\footnotetext{
${ }^{87}$ COSTA, Iná. Brecht e o teatro épico. Literatura e Sociedade, v. 15, n. 13, p. 214-233, 29 jun. 2010, p.215.
} 
Embora o termo épico fosse usado de modo pejorativo, a expressão "Teatro Épico", para os adeptos das temáticas trabalhistas, tornou-se completamente positiva, como se fosse uma forma de identidade para esse novo teatro que surgia.

Embora Piscator tenha sido o precursor do Teatro Épico, não conseguiu manter da maneira que gostaria o seu Teatro Político:

\begin{abstract}
Apoiado embora em organizações destinadas a facilitar aos operários o acesso ao teatro, Piscator teve de verificar que a fraca capacidade econômica dos operários alemães da época não lhe permitia sustentar um teatro que se destinasse essencialmente ao proletariado. Uma das contradições de muitos países chamados democráticos é o fato de bens culturais tão importantes como o teatro não serem acessíveis a vastas camadas do povo, não só por causa do preço da entrada, mas também por toda uma série de outros fatores econômico-sociais e educacionais que marginalizam os operários e camponeses e os mantêm afastados ou mesmo desinteressados dos valores e fontes de conscientização. ${ }^{88}$
\end{abstract}

Nesse contexto de afastamento do público que se dirige às peças políticas, Piscator se vê realizando um trabalho para um público contrário ao que ele esperava. Nesse contexto, Rosenfeld afirma que: “o teatro revolucionário de Piscator atraía principalmente uma burguesia sofisticada, ávida de 'novidades' cênicas." ${ }^{89}$

A avidez por "novidades cênicas" ocorre porque Piscator tinha uma nova forma de fazer teatro. Segundo Rosenfeld: “As concepções cênicas de Piscator decorrem da ideia central do teatro como instituição político-didática. Conscientemente, subordinou a esta ideia a da arte: todos os recursos estéticos e técnicos deveriam ser postos a serviço da função política do teatro." 90

Dessa maneira, o Teatro Piscatoriano priorizava a forma como modo de fortificar a função política e didática de seu teatro. Para isso, Piscator utilizava-se de elementos de documentários para servir de instrumento de mediação entre o público e a peça:

Para o teatro político de Erwin Piscator, o que estava em jogo era a relevância da impessoalidade: o palco piscatoriano preocupa-se na verdade em revelar ao público as circunstâncias externas que moldam os acontecimentos da sociedade. Por isso, ele insere em seu teatro uma técnica de narrativa documental que funciona como uma espécie de elemento midiático entre o público e a representação. É o elemento épico e distanciado que impõe um grau de afastamento crítico e consciente do espectador diante do que assiste em cena. Para Piscator, a ação cênica não se configura mais do ponto de vista aristotélico, mas sim na sua relação intrínseca com a realidade social

\footnotetext{
${ }^{88}$ ROSENFELD, Anatol. Brecht e o teatro épico. São Paulo: Perspectiva, 2012, p.48.

${ }^{89}$ Ibid., p.48.

${ }^{90}$ Ibid., p.49.
} 
e política. Talvez a ação cênica codificada no seu teatro possa receber uma outra nomenclatura, como ação transformadora/revolucionária. ${ }^{91}$

Assim, o Teatro Político de Piscator já utilizava técnicas de distanciamento a fim de afastar o público da peça encenada, característica importantíssima nos estudos do Teatro Épico.

\subsection{BERTOLT BRECHT E RECURSOS DO TEATRO ÉPICO}

Eugen Friederich Bertolt Brecht foi um grande poeta, romancista, dramaturgo, considerado um dos grandes escritores do século XX. Também conhecido por Bertolt Brecht, Bert Brecht e B.B., esse artista iniciou sua carreira muito jovem, enquanto estudava medicina e participou, como enfermeiro, da Primeira Guerra Mundial.

Esse momento de experiência única levou Brecht a escrever "Balada do soldado morto", e, a partir disso, cada vez mais sua arte se apresentava balizada em preocupações sociais da época, tendo como norte as teorias marxistas. Como artista interessado em mudanças sociais, Bertolt Brecht acreditava que, por meio da arte, no caso o teatro, era possível alterar a consciência do espectador que, muitas vezes, nem tinha ideia de toda a sua situação, por um lado, de exclusão, porém, de outra, de poder de revolução. Logo, o dramaturgo dava ao teatro uma função social. De acordo com Furtado: "Ele [Brecht] nos legou o exemplo de um teatro histórico, voltado para o homem, onde se preteria identificação e a purgação catártica do espectador, pela atitude crítica do mesmo." 92

Essa consciência de si e do mundo que o espectador ganharia por meio do espetáculo é uma das características fundamentais do teatro diferenciado a que Brecht estava dando continuidade, já que outros dramaturgos já faziam Teatro Político:

Fora da Alemanha, Bertolt Brecht é conhecido, quase exclusivamente, como um dos grandes renovadores do teatro moderno. Fala-se muito do seu teatro anticulinário ou antiaristotélico, da sua teoria cênica que se opõe ao palco mágico, destinado a hipnotizar o público e a suscitar-lhe efusões sentimentais e emoções gratuitas. $\mathrm{O}$ teatro didático de Brecht, bem ao contrário, procura estimular no público uma

\footnotetext{
${ }^{91}$ GIORDANO, Davi. II Congreso Internacional de Artes en Cruce: bicentenarios latinoamericanos y globalización. Disponível em: http://artesencruce.filo.uba.ar/sites/artesencruce.filo.uba.ar/files/14ArteyPoliticaGiordano.pdf. Acesso em: 05 mai. 2019.

${ }^{92}$ FURTADO, Marli Terezinha. Bertolt Brecht e o teatro épico, p.45. Disponível em: https://periodicos.ufsc.br/index.php/fragmentos/article/download/4826/4132.Acesso em: 05 fev. 2019.
} 
atitude de crítica e vigilância, propícia ao raciocínio e à análise dos problemas sociais. ${ }^{93}$

Nesse sentido, Brecht acaba se firmando com o seu teatro totalmente contrário aos moldes do Teatro Dramático absorvido pelos dramas burgueses, individuais, cujos temas restringem-se aos da esfera privada, nunca alcançando a esfera da vida pública e, portanto, política da sociedade.

Segue, abaixo, o quadro de Brecht ${ }^{94}$ em que é separada a forma dramática, clássica do teatro, da forma épica brechtiana:

\begin{tabular}{|c|c|}
\hline Forma dramática do teatro & Forma épica do teatro \\
\hline 1. O palco "corporifica" uma ação; & Relata a ação; \\
\hline 2. Envolve o espectador numa ação, e? & Torna-o um observador; \\
\hline 3. Consome sua atividade; & Desperta sua atividade; \\
\hline 4. Torna possíveis os seus sentimentos; & Força-o a tomar decisões; \\
\hline 5. Proporciona-lhe emoções, vivências; & Proporciona-lhe conhecimentos; \\
\hline $\begin{array}{l}\text { 6. O espectador é transportado para dentro } \\
\qquad \text { de uma ação; }\end{array}$ & Ele é contraposto a ela; \\
\hline 7. Trabalha-se com sugestões; & Trabalha-se com argumentos; \\
\hline 8. Os sentimentos são conservados; & Eles são levados até o reconhecimento; \\
\hline $\begin{array}{l}\text { 9. Pressupõe-se o homem como já } \\
\text { conhecido; }\end{array}$ & O homem é objeto de investigação; \\
\hline 10. O homem é imutável; & O homem é mutável e agente de mutações; \\
\hline 11. Tensão em relação ao desfecho; & Tensão em relação ao andamento; \\
\hline 12. Cada cena liga-se à outra; & Cada cena para si mesma; \\
\hline $\begin{array}{l}\text { 13. Os acontecimentos decorrem } \\
\text { linearmente; }\end{array}$ & Decorrem em curvas; \\
\hline 14. A natureza dá saltos; & Dá saltos; \\
\hline 15. O mundo tal como ele é; & O mundo tal como se transforma; \\
\hline
\end{tabular}

\footnotetext{
${ }^{93}$ ROSENFELD, Anatol. Brecht e o teatro épico. São Paulo: Perspectiva, 2012, p.52.

${ }^{94}$ Apud BORNHEIM, Gerd. Brecht: a estética do teatro. Rio de Janeiro: Graal, 1992, p. 139 e 140.
} 


\begin{tabular}{|c|c|}
\hline 16. O homem como deve ser; & O que é imperativo que ele faça; \\
\hline 17. Seus impulsos; & Seus motivos de movimento; \\
\hline 18. O pensamento determina o ser. & O ser social determina o pensamento. \\
\hline
\end{tabular}

Alguns desses elementos foram utilizados na análise realizada, porém é imprescindível ressaltar que não se teve como objetivo detectar a oposição entre ambos os tipos de teatro na literatura de Bojunga. É importante esclarecer esse aspecto, já que as últimas obras da autora, com exceção de Intramuros, tratam de assuntos mais sociais, o que poderia levar a uma pseudodicotomia: obras iniciais da autora são constituídas somente de elementos do Teatro Clássico, ao passo que as últimas são estruturadas somente à base do Teatro Épico. Sobre essa dicotomia, o Dicionário de Teatro, de Patrice Pavis, afirma que:

\begin{abstract}
Durante muito tempo - e isto, é claro, deve ser mais uma vez culpa de Brecht! separou-se radicalmente um teatro dos processos históricos e uma dramaturgia da intimidade fantasiosa. Semelhante cisão tem causas objetivas: a dificuldade de conciliar uma visão externa 'objetiva' e uma sensibilidade lírica, a concorrência ideológica e episdemológica do marxismo e da psicanálise, mas também causas inconfessas e, elas próprias, fantasiosas: a recusa em estabelecer vínculo entre a neurose individual e a opressão social, em admitir que a visão histórica pode ser apenas fantasiada e que a fantasia também é, por outro lado, atravessada pela história. ${ }^{95}$
\end{abstract}

Portanto, não se podem fazer esses tipos de classificações radicais, visto que a arte trata de muitos assuntos ao mesmo tempo, por meio de mais de um tipo de forma.

Ao se estudar o Teatro Épico brechtiano e um pouco da vida de Bertolt Brecht, podese ter a falsa ideia de que suas peças são niilistas ou que não apresentam nenhuma preocupação artística, como normalmente se imagina da literatura engajada. No entanto, o teatro de Brecht vai além dessas ideias:

O teatro épico de Brecht não se satisfaz em ser mero teatro, embora pretenda ser plenamente teatro. A sua arte extravasa da moldura do campo cênico-lúdicoestético. Invadindo a plateia, pelo apelo direto ao público, visa invadir a realidade. É uma arte que se entende determinada pela vida e que procura, por sua vez, determinar a vida. ${ }^{96}$

Nesse sentido, não se pode afirmar que um teatro que procura romper com a ilusão de vida perfeita traduzida pela burguesia nos palcos é um teatro sem elementos lúdicos e

95 PAVIS, Patrice. Dicionário de teatro. São Paulo: Perspectiva, 2015, p.163.

96 ROSENFELD, Anatol. Brecht e o teatro épico. São Paulo: Perspectiva, 2012, p.36. 
estéticos. Não é possível afirmar que os conteúdos sociais - estejam eles no teatro ou na literatura - trazem consigo a distopia, pelo contrário:

Sem dúvidas, para Brecht, o propósito didático é de importância primordial; deseja difundir no meio da miséria dos horrores da guerra, uma mensagem de esperança: os males não são eternos, a paz e a bondade não são sonhos e utopias; o mundo e a sociedade são mutáveis; é possível transformar o homem. Explica-se daí a ênfase com que combate o teatro trágico, na medida em que concebe o homem como um ser sujeito a um destino imutável, eterno. ${ }^{97}$

Nesse sentido, o Teatro Épico opõe-se ao Teatro Clássico. Rosenfeld explicita as duas principais razões para a existência dessa oposição: a insuficiência do drama em somente retratar as relações inter-humanas sob uma perspectiva individual e o objetivo didático da obra brechtiana.

Acerca da primeira razão, é levado em consideração que o drama clássico apresenta somente conflitos que dizem respeito aos indivíduos, sem haver a reflexão sobre os determinantes sociais que originaram tal situação:

\footnotetext{
Segundo a concepção marxista, o ser humano deve ser concebido como o conjunto de todas as relações sociais e, diante disso, a forma épica é, segundo Brecht, a única capaz de apreender aqueles processos que constituem para o dramaturgo a matéria para uma ampla concepção do mundo. ${ }^{98}$
}

Sendo Brecht marxista, acreditava que a História tinha papel fundamental nas relações sociais e que estas precisam ser abordadas de uma perspectiva social, não individual. Aplicase essa ideia ao que acontece em Sapato de Salto, uma vez que a protagonista da história transforma-se em prostituta em decorrência da sequência de fatos trágicos que acontece em sua vida, fatos esses relacionados a desigualdades sociais e à exploração sexual feminina, que são problemas históricos, que ultrapassam a vida de uma personagem, sendo, portanto, um problema de um grupo social historicamente discriminado. Ao acompanhar esse processo na vida de Sabrina, o leitor é capaz de compreender que a criança não se torna prostituta por vontade própria, que, na verdade, é levada a fazer isso por necessidade. Assim, a citação de Rosenfeld "o homem concreto só pode ser compreendido com base nos processos dentro e através dos quais existe." ${ }^{99}$ pode ser aplicada adequadamente ao contexto de vida de Sabrina, o que levaria Sapato de salto a se aproximar de um drama épico. Essa mesma citação de Rosenfeld pode ser compreendida ao se tomar como base comparativa duas personagens de

\footnotetext{
${ }^{97}$ ROSENFELD, Anatol. Brecht e o teatro épico. São Paulo: Perspectiva, 2012, p.52.

${ }^{98}$ Ibid., p.147.

${ }^{99}$ Ibid., p.82.
} 
Retratos de Carolina: Carolina e sua mãe. Ao passo que a mãe de Carolina compreende que uma mulher precisa de um marido, não tem necessidade de trabalhar, nem de estudar; Carolina é o completo oposto, dado que, apesar de ter uma mãe repressora, tinha um pai bastante diferente desta, o que pôde dar oportunidade de Carolina não ser totalmente formada pela perspectiva moralista da mãe.

Sobre a segunda razão, o intuito didático do Teatro Épico opõe-se ao Teatro Clássico desenvolvido pela burguesia da época, uma vez que não se fundamenta na ilusão criada pelo Teatro Burguês, porque sua maior preocupação não é passar para o público a existência de um mundo perfeito, mas sim um mundo que precisa de mudanças sociais, que são sempre possíveis, já que os problemas a serem combatidos não são imutáveis, são históricos, passíveis, portanto, de transformações. Estas, na visão brechtiana, podem ocorrer por intermédio do teatro cuja intenção é a de:

\begin{abstract}
apresentar um 'palco científico' capaz de esclarecer o público sobre a sociedade e sobre a necessidade de transformá-la. O fim didático exige que seja eliminada a ilusão, o impacto 'mágico' do teatro burguês. Por isso, impõem-se recursos narrativos que inserem a característica 'distância' entre narrador (e o público), de um lado, e do mundo narrado, de outro - distância que não existe no drama tradicional, visto as personagens atuarem nele, com plena autonomia, em vez de serem projetadas a partir da perspectiva do narrador. ${ }^{100}$
\end{abstract}

É visível, em Retratos de Carolina, que Lygia Bojunga, após terminar a narrativa da obra, dá liberdade à personagem para que ela mesma escreva, sem, aparentemente, ser guiada pela autora, já que fica explícito que a autora estaria ausente nesses momentos. Esse é um recurso que demonstra a autonomia e liberdade a que a personagem Carolina chega ao fim da obra, de modo que a própria personagem reivindica à autora um outro final que não aquele que ela lhe deu. Essa autonomia da personagem leva o leitor/público a se distanciar da narrativa central, conseguindo não apenas identificar o processo de escrita pelo qual Bojunga passa, mas também notar que é possível haver uma transformação positiva na vida da personagem a ponto de lhe proporcionar ainda mais independência.

A fim de compreender a possibilidade de mudanças, o drama épico precisa distanciar o público do que está sendo vivido no palco, ao contrário do que acontece com o drama clássico e burguês:

A nossa própria situação, época e sociedade devem ser apresentadas como se estivessem distanciadas de nós pelo tempo histórico ou pelo espaço geográfico.

${ }^{100}$ ROSENFELD, Anatol. Brecht e o teatro épico. São Paulo: Perspectiva, 2012, p.82. 
Desta forma o público reconhecerá que as próprias condições sociais são apenas relativas e, como tais, fugazes e não ‘enviadas por Deus'. Isso é o início da critica. Para empreender é preciso compreender. Vendo as coisas tal qual elas são, elas se tornam corriqueiras, habituais, e, por isso, incompreensíveis. ${ }^{101}$

Esse distanciamento é considerado dialético, pois há uma situação inicial em que o público distancia-se dos problemas sociais; em um segundo momento, há o estranhamento oriundo desse distanciamento, pois se passa a refletir sobre assuntos nunca antes pensados da maneira exposta; por último, quando se tem, de fato, a compreensão dos problemas sociais, é possível pôr em prática a mudança. Dessa forma, o que não era conhecido passa a sê-lo. Já no drama clássico, conforme Rosenfeld, isso não ocorre:

Para empreender é preciso compreender. Vendo as coisas como elas sempre estão ocorrendo, elas se tornam corriqueiras e, por isso, incompreensíveis, porque, estando identificados com elas pela rotina, não as vemos com o olhar épico da distância. ${ }^{102}$

Gerd Bornheim elenca duas citações de Brecht para caracterizar o distanciamento dialético:

\begin{abstract}
Distanciar um acontecimento ou um caráter significa antes de tudo retirar do acontecimento ou do caráter aquilo que parece o óbvio, o conhecido, o natural, e lançar sobre eles o espanto e a curiosidade (III, 101)

A finalidade dessa técnica do efeito do distanciamento consiste em emprestar ao espectador uma atitude crítica, de investigação relativamente aos acontecimentos que deveriam ser apresentados. Para isso, os meios eram artísticos (III, 155) ${ }^{103}$
\end{abstract}

Tomando como exemplo Sapato de salto, a primeira citação pode ser relacionada ao início da obra, quando, após o abuso sexual, Sabrina decide continuar na casa da família para quem trabalha por ser a melhor opção para ela, já que ela não queria voltar para o orfanato de onde saiu. Em um primeiro momento, o esperado seria a menina querer sair da casa onde passa por diversas formas de violência. Mas, como ela não toma a atitude mais óbvia, pode haver o espanto e, ao mesmo tempo, a curiosidade do leitor em saber o que ocorrerá futuramente. $\mathrm{O}$ mesmo espanto pode ocorrer ao se perceber que a protagonista opta por se prostituir - mas ter condições financeiras de cuidar da avó, que fora o único integrante da família que lhe restou - a voltar para o orfanato.

A segunda citação enfoca os meios artísticos como forma importante para o distanciamento e a existência do senso crítico do leitor. Nesse sentido, todos os recursos já

\footnotetext{
${ }^{101}$ ROSENFELD, Anatol. Brecht e o teatro épico. São Paulo: Perspectiva, 2012, p.35.

102 Ibid., p.8.

${ }^{103}$ BORNHEIM, Gerd. Brecht : a estética do teatro. Rio de Janeiro: Graal, 1992, p.243.
} 
mencionados, como a postura, os gestos, as metáforas, o lirismo, entre outros, ajudam na tomada de consciência do leitor, após ter-se afastado tanto do problema social abordado:

O efeito de alienação, afastamento ou 'desfamiliarização', procura, portanto, produzir aquele estado de admiração e estranhamento que para os gregos se afigurava como o início da investigação científica e do conhecimento. A fim de produzir esse efeito, Brecht elaborou um arsenal inesgotável de técnicas e recursos literários, como o uso da ironia e da paródia, tratamento diferente da linguagem, da estrutura das peças e das personagens; recursos cênicos literários, como cartazes e projeções de textos, mediantes os quais o próprio autor comenta epicamente as ocorrências e esboça, de forma narrativa, o pano de fundo social. ${ }^{104}$

Dessa maneira, o processo inicial de distanciamento leva o espectador/leitor ao conhecimento de uma situação que, com o passar do tempo, foi banalizada e não deveria ter sido. Para desconstruir tal banalização, todos os elementos teatrais, além das palavras, são extremamente fundamentais para a construção do (re)conhecimento que se terá da peça encenada/lida.

Ao se obter o efeito de estranhamento, o espectador/leitor chega à crítica da realidade banalizada, entretanto tal postura não é válida somente para o momento de duração da peça. $\mathrm{O}$ objetivo de todas as características próprias do Teatro Épico é levar aquele que assiste à peça ou a lê a notar que nenhuma condição social, mesmo que histórica, é permanente:

\begin{abstract}
A plateia deve começar a estranhar aquilo que o hábito lhe tornou familiar. As coisas que nos parecem muito familiares, e por isso naturais e imutáveis, devem ser distanciadas, tornadas estranhas. O que há muito não muda parece imutável. A peça deve, portanto, caracterizar determinada situação na sua relatividade histórica para demonstrar sua condição passageira e imutável. A nossa própria situação, época e sociedade devem ser apresentadas como se estivessem distanciadas de nós pelo tempo histórico ou pelo espaço geográfico. ${ }^{105}$
\end{abstract}

Essa visão diferenciada, desiludida, deformada, descontinuada da realidade ocorre por meio de um processo dialético que leva o espectador/leitor a passar por uma tese e antítese que, juntas, possibilitarão uma síntese, um resultado ainda não visto, uma possibilidade nova de realidade:

A teoria é dialética: a anulação da familiaridade da nossa situação habitual, a ponto
de ela se afigurar estranha a nós mesmos, transforma em grau mais elevado esta
nossa situação, mais conhecida e mais familiar. Através do choque do não
conhecer, é suscitado o choque do conhecer, a negação é negada. A função do
distanciamento é, portanto, a de anular-se a si mesma - é um distanciamento que
aproxima. Somente mercê do choque da incompreensão (momentânea) chegamos
ao estalo da compreensão - compreensão crítica, contudo, que não traz uma lição
unilateral, mas que se reveste de suficiente ambiguidade para impor ao espectador

104 ROSENFELD, Anatol. Brecht e o teatro épico. São Paulo: Perspectiva, 2012, p.84.
105 Ibid., p.34. 
um processo de reflexão própria, de tomada de consciência das contradições humanas e sociais. ${ }^{106}$

Esse "processo de reflexão própria" a que Rosenfeld relacionou à "tomada de consciência das contradições humanas e sociais" está, também, ligado à ambiguidade de dar chance ao espectador/leitor de pensar os caminhos possíveis para transformação do mundo.

A exemplo disso, em Sapato de salto, ao longo de toda a obra, o leitor é chamado a acreditar em uma nova esperança que se segue após uma grande tragédia na vida da personagem Sabrina. Seja a esperança de encontrar um lar - a casa em que ela sofre o primeiro estupro -; seja a esperança de sair desse "lar" extremamente violento, que é concretizada com a chegada da Tia Inês para buscar Sabrina; seja na tomada de decisão de Paloma em adotar a menina e em cuidar também da avó dela: todas as esperanças são questionáveis para o leitor, uma vez que, cada uma delas, com exceção da última (não se sabe o que acontece com Sabrina no novo núcleo familiar de Paloma, pois a obra termina), podem levar o leitor a refletir se, de fato, a esperança que se mostra a cada capítulo é, realmente, o melhor caminho de transformação da realidade. Embora o leitor tenha a possibilidade de questionamentos, a esperança, com ou sem questionamentos, também é um sentimento das personagens envolvidas na narrativa: Sabrina quer uma família, sonha em ser dançarina; Paloma também quer ter uma família sem brigas constantes como tinha com seu marido fazendo parte de seu núcleo familiar. Por Sapato de salto ser uma obra com traços do Teatro Épico, é possível afirmar que essas esperanças podem proporcionar diferentes reações e reflexões no leitor, como a de acreditar que a obra encerra-se com um final feliz, ou com a de considerar a estrutura da obra - alternância entre esperança e tragédia - como permanente, isto é, a tragédia viria a acontecer novamente.

No que concerne às diferenças do Teatro Épico para o clássico, ademais, pode-se mencionar a não preocupação com as regras rigorosas do Teatro Aristotélico:

Distingue-se pela sua estrutura mais aberta, repleta de episódios que não se
integram na linha de uma ação una, contínua de tempo reduzido e lugar fixo (ou
seja, o teatro épico rompe as chamadas unidades de ação, tempo e lugar). Abre-se a
um mundo maior pela própria variedade de tempos, lugares e episódios que
apresenta e, dessa forma, ultrapassa o diálogo interindividual pela riqueza cênica,
pela multiplicidade de elementos visuais e imaginários que tendem quase a se
sobrepor à exposição puramente verbal, declamada. Há saltos no tempo e no
espaço que pressupõem a intervenção de um narrador (mesmo que não explícito)
que, sem se preocupar com a concatenação causal rigorosa da ação, seleciona de

${ }^{106}$ ROSENFELD, Anatol. Brecht e o teatro épico. São Paulo: Perspectiva, 2012, p.35. 
um tecido de eventos múltiplos, entrelaçados com outros eventos, os episódios que se lhe afiguram dignos de serem representados. ${ }^{107}$

Sendo assim, o Teatro Épico propicia ao narrador (inclusive ao narrador literário que está inserido em uma narrativa que utiliza recursos do Teatro Épico) e aos outros efeitos extra-verbais (que contribuem com o diálogo teatral e, portanto, integram o universo dos signos, propiciando-lhe maior verossimilhança, como cenário, iluminação, acústica, música, cores, figurinos, maquiagem, adereços, gestualidade, voz) o cerne da peça, não havendo mais a necessidade de se zelar, em primeiro lugar, pelas unidades primordiais do Teatro Aristotélico: ação, tempo e lugar.

Nesse sentido, pode-se dizer que, em algumas obras de Lygia Bojunga, a autora utiliza esses recursos do Teatro Épico, a exemplo da obra Sapato de salto, em que há a interferência do narrador na organização das cenas/capítulos, uma vez que, embora, aparentemente o romance seja linear, o narrador dá saltos no tempo: ora ele pára a narrativa principal para explicar fatos passados - como a morte da mãe de Sabrina, como o passado de Tia Inês, como o ocorrido com Betina - ora precisa explicar, mesmo que de maneira sucinta, a mudança de espaço, de personagem em foco. Como exemplo, seguem o fim do capítulo, em que Sabrina chega à casa de Tia Inês, e o início do capítulo sobre Andrea Doria:

Sabrina parou atrás da Tia Inês, imaginando o Andrea Doria seguindo pela rua (será que ele já tinha visto a Lua?)

6.

A lua e

ANDREA DORIA

Viu, sim. E foi ralentando o passo pra curtir melhor a claridade que se espalhava pelo anoitecer. Pensando que pra quem contava primeiro que a Inês era mesmo legal: tinha concordado dançar com ele cobrando de 'mãe pra filho'. As aulas começavam na terça-feira.

Andrea Doria estava contente. De olho na lua, ensaiou um passo de dança. ${ }^{108}$

A concatenação entre um capítulo e outro ocorre por meio da voz do narrador em terceira pessoa. A exemplo disso, há o último trecho do capítulo 5, que é escrito entre parênteses por meio do discurso indireto livre, que deixa a dúvida para o leitor sobre a quem se atribui esse trecho? Ao pensamento de Sabrina ou ao narrador reproduzindo-o?

\footnotetext{
${ }^{107}$ ROSENFELD, Anatol. Brecht e o teatro épico. São Paulo: Perspectiva, 2012, p. 29.

108 BOJUNGA, Lygia. Sapato de salto. Rio de Janeiro: Casa Lygia Bojunga, 2006, p.59.
} 
Independentemente dessa dúvida, o início do capítulo seguinte continua sendo contado pelo narrador para que o leitor possa perceber a mudança espacial - da casa da Tia Inês para a rua por onde Andrea Doria estava andando e pensando sobre as aulas de dança que começaria. Em várias outras partes da obra, por mais que a autora não use a narração, tentando apresentar as personagens, por exemplo, pela voz das próprias personagens, nem sempre o diálogo dá conta, sendo necessária a intervenção do narrador. Essa intervenção pode ser vista, também, mesmo que em poucos momentos, em Retratos de Carolina e em Aula de inglês, quando o narrador explica alguma informação não esclarecida anteriormente, por meio de nota de rodapé, o que é uma técnica dificilmente utilizada por Bojunga. Logo, mesmo não sendo um narrador brechtiano, com longos comentários acerca do que se vê em peça ou texto literário, nota-se que a voz do narrador - seja ele onisciente, personagem ou autor - nas últimas obras de Lygia Bojunga, faz-se presente.

Nesse sentido, não é por acaso que a autora passa a incluir em suas obras o Pra você que me lê, que é um comentário sobre a obra assinado pela autora. Esse comentário leva o leitor ao distanciamento da narrativa, à quebra da ilusão dramática proporcionada pelo drama burguês. Esse é um recurso significativo do Teatro Épico. Entretanto, como esse recurso surge somente na fase mais recente de Bojunga, a autora, mesmo com o funcionamento da sua editora Casa Lygia Bojunga, não se atreveu a editar (mudar) as obras já escritas em outra fase:

Em cada um desses livros a que venho agora me dedicando a publicar - lendo,
relendo, planejando, executando -, quantas vezes sofri a tentação de retrabalhar as
frases, períodos, sequiências e até desfechos; quantas vezes parei a leitura e anotei na
margem um outro jeito de exprimir um sentimento, uma emoção, pensando: este
jeito é muito mais meu! Mas, pouco depois, me corrigindo: é mais meu hoje, agora,
mas quando eu escrevi estas páginas meu jeito ainda não tinha passado pelas
transformações que,a cada ano, a vida vai operando em nós: se eu começo a querer
imprimir no livro meu jeito de agora, eu vou estar traindo a escritora que escreveu
este texto aqui. Então, fora uma palavra ou outra truncada, repetida, engolida que
agora suprimi, acrescentei, corrigi, meus textos têm permanecido inalteráveis.

Outro recurso do Teatro Épico são as personagens marginalizadas, visto que Brecht dialoga com temas e personagens que não são comuns no palco do Teatro Burguês, já que o artista:

impelido por um veemente elo anárquico, se refugia no mundo dos 'marginais' - dos vagabundos, das prostitutas, rufiões e infanticidas. É como se [...] negando uma

${ }^{109}$ BOJUNGA, Lygia. Livro - um encontro 6. ed. Rio de Janeiro: Casa Lygia Bojunga, 2007, p.95. 
sociedade cuja aparente normalidade produziria a guerra, se evadisse no exotismo romântico dos esgotos, em busca da inocência de assassinos e aventureiros. ${ }^{110}$

É comum que as personagens do Teatro Épico não correspondam a padrões sociais. Essa característica do Teatro Épico é encontrada na literatura de Lygia Bojunga, porque a maioria de suas personagens não se enquadram em paradigmas sociais, como pode ser observado em alguns exemplos a seguir:

Em Os colegas (1972), os cachorros vira-latas são personagens que vivem nas ruas;

Em Angélica (1975), há personagens que passam fome;

Em A casa da madrinha (1978), o protagonista, que é uma criança, é morador de uma comunidade e precisa trabalhar para auxiliar financeiramente a família.

Em Corda bamba (1979), há o pai da protagonista pertencente a uma classe social completamente diferente à da mãe dela, além de existir uma personagem contadora de histórias, que é miserável.

Em Tchau (1984), há uma personagem que é morador de uma comunidade e bolsista em uma escola particular.

Em A cama (1996), há personagens moradoras de uma comunidade.

Em Retratos de Carolina (2002), a protagonista aborta um filho.

Em Aula de inglês (2006), uma das personagens engaja-se em causas sociais.

Em Sapato de salto (2006), a protagonista transforma-se em uma prostituta infantil, além de haver uma personagem homossexual.

Em Querida (2009), há duas personagens tão necessitadas que não têm recursos financeiros para comprar passagens de ônibus.

Em Intramuros (2016), a família do Gari e de Garibalde são muito pobres.

Já se tendo elencado alguns dos recursos do Teatro Épico usados na literatura de Lygia Bojunga, passa-se à análise dos recursos do Teatro Mambembe.

\footnotetext{
${ }^{110}$ ROSENFELD, Anatol. Brecht e o teatro épico. São Paulo: Perspectiva, 2012, p.59.
} 
No palco, na praça, no circo, num banco de jardim Correndo no escuro, pichado no muro Você vai saber de mim

(...)

Mendigo, malandro, moleque, molambo, marginal Escravo fugido ou louco varrido Vou fazer meu festival (...) Poeta, palhaço, pirata, corisco, errante judeu, cantando Dormindo na estrada, não é nada, não é nada E esse mundo é todo meu Mambembe, cigano Debaixo da ponte cantando Por baixo da terra, cantando Na boca do povo, cantando

Chico Buarque

Mambembe é a companhia nômade, errante, vagabunda, organizada com todos os elementos de que um empresário pobre possa lançar mão num momento dado, e que vai, de cidade em cidade, de vila em vila, de povoação em povoação, dando espetáculos aqui e ali, onde encontre um teatro ou onde possa improvisá-lo. 


\section{TEATRO MAMBEMBE}

De acordo com o Dicionário Houaiss, o substantivo mambembe significa:

1. Localidade afastada, desabitada; ermo 2 TEAT conjunto teatral ambulante, pobre e de má qualidade, geralmente formado por atores amadores, que percorrem cidades do interior 3 TEAT grupo teatral ambulante 4 TEAT grupo teatral de má qualidade 5 imfrm indivíduo sem valor, sem préstimo, medíocre. ${ }^{11}$

Nota-se que a maioria das acepções do termo está relacionada ao teatro, por essa razão é fundamental considerar a sua acepção em dicionário específico desse tipo de arte. Assim, mambembe, segundo o Dicionário de Teatro ${ }^{112}$ é:

originalmente, um dançarino de teatro. A palavra (no original francês) vem do latim vulgar ballare; designa hoje o saltimbanco. Trupes de mambembes de histriões e saltimbancos cruzavam antigamente a Europa realizando espetáculos populares em tablados. Esses atores mambembes - clowns, acrobatas, malabaristas, mas às vezes também cantores e poetas - se produziam sempre à margem dos teatros oficiais.

Considerando essas definições, é possível resumi-las:

Os artistas que se tornaram mais conhecidos como mambembes foram os cômicos dell'arte também considerados, no geral, como os primeiros atores profissionais da história do teatro ocidental, sendo o próprio termo 'arte' usado, na época, para designar habilidade ou ofício. O termo que, outrora, se referia ao profissionalismo teatral, atualmente, carrega a conotação pejorativa de ordinário e imprestável. No entanto, seu caráter essencial diz respeito à itinerância. Efetivamente, mambembar significa viajar com um espetáculo. ${ }^{113}$

Nesse sentido, o Teatro Itinerante, o Mambembe e o Circense estão relacionados, visto que têm caráter nômade e popular. Essa associação ocorre há muito tempo desde as celebrações dionisíacas. Estas, muito comuns no período da Grécia Antiga, eram festas públicas que homenageavam Dionísio, o deus do vinho e das festividades. Nessa época, o ator Téspis, extremamente inovador, participou desses eventos e trouxe-lhes certa influência de

${ }^{111}$ HOUAISS, Antonio; VILLAR, Mauro de Sales. Dicionário Houaiss da língua portuguesa / Antonio Houaiss e Mauro de Sales Villar, elaborado pelo Instituto Antonio Houaiss de Lexicografia e Bancos de Dados da Língua Portuguesa S/C Ltda. Rio de Janeiro: Objetiva, 2009, p.1226.

112 PAVIS, Patrice. Dicionário de teatro. São Paulo: Perspectiva, 2015, p.231.

113 WILTGEN, Ana Beatriz. Itinerância: um conceito em trânsito na cena brasileira. VI Congresso de Pesquisa e Pós-Graduação em Artes Cênicas 2010. Disponível em: http://www.portalabrace.org/vicongresso/territorios/Ana\%20Beatriz\%20Wiltgen\%20$\% 20 I t i n e r \%$ E2ncia\%20_\%20Um\%20conceito\%20em\%20tr\%E2nsito\%20na\%20cena\%20brasileira.pdf. Acesso em 10 jun. 2019. 
experiências anteriores, itinerantes, que teve por meio de suas apresentações: "ele perambulava pela zona rural com uma pequena troupe de dançarinos e cantores" 114

Por ser nômade,

\begin{abstract}
supõe-se que viajasse numa carroça de quadro rodas, 'o carro de Téspis' (...). Mas essa informação diz respeito somente à sua participação na Dionisíacas, e não algo como uma carroça-palco ambulante. O ritual da dança coral e do teatro era precedido por uma procissão solene (...). O clímax dessa procissão era o carro festivo do deus puxado por dois sátiros, uma espécie de barca sobre rodas que carregava a imagem do deus. ${ }^{115}$
\end{abstract}

Tem-se aqui, possivelmente, o primeiro teatro relacionado ao mambembe, em que se pode notar o caráter popular e festivo desse tipo de arte. Essas mesmas características, explícita ou implicitamente, aparecem em algumas obras de Bojunga. A escritora, em sua obra Feito à mão, apresenta um capítulo chamado As Mambembadas, que foi um projeto realizado pela própria autora, unindo suas duas paixões: a literatura e o teatro. Por isso, é fundamental ser feita uma contextualização dessa obra para se compreender a relação de Lygia Bojunga com o Teatro Mambembe para, posteriormente, serem apresentados alguns dos tipos de teatros itinerantes, como o mambembe, o circense, o de rua, que tanto permeiam a obra da autora. Logo, essa é uma das obras que faz menção explícita ao Teatro Mambembe.

\title{
5.1. AS MAMBEMBADAS
}

Feito à mão surgiu da vontade da autora em falar sobre o seu "eu-artesã" e de se colocar frente a um mundo cada vez mais tecnológico, pouco manual. Essas vontades são explicadas no começo da obra por meio do Pra você que me lê. Nesse espaço, Bojunga afirma que o Feito à mão é a segunda iniciativa editorial, depois de seu projeto As Mambembadas, da Casa Lygia Bojunga, editora fundada pela própria escritora. Nesse contexto de projetos, Bojunga deixa clara a sua vontade de criar uma obra que, da perspectiva de um processo artesanal, dar-lhe-ia um imenso trabalho, mas também uma gigantesca satisfação.

No começo deste capítulo, a autora afirma seu conhecimento sobre a história do teatro e o seu apreço especial pelo Teatro Mambembe:

\footnotetext{
${ }^{114}$ BERTHOLD, Margot. História Mundial do Teatro .Tradução Maria Paula v. Zurawski, J. Guinsburg, Sérgio Coelho e Clóvis Garcia. - 6. Ed. - São Paulo: Perspectiva, 2014.p.105.

${ }^{115}$ Ibid, p.105.
} 
Chamei de Mambembadas essas viagens que fiz pelo Brasil: quando estudei a história do teatro, de saída eu simpatizei com os atores mambembes; e uma das peças que eu gostei mais de ver em cena foi, justo, $O$ Mambembe, de Artur Azevedo, onde ele retrata a vida desses atores que se embrenham pelo país adentro, levando de cidade a cidade o seu modesto fazer teatral. Mudaram os tempos, mas a minha simpatia pelos mambembes continua a mesma. ${ }^{116}$

Nesse sentido, a autora inspirou-se nessa peça e nesse tipo de teatro para realizar o seu projeto As Mambembadas. Uma dessas influências é o uso de poucos recursos para a realização da peça, o que é típico do Teatro Mambembe, como ilustra a própria peça de Artur Azevedo: "a burleta azevediana não possui múltiplos espaços e diversas mutações cenográficas, mas fica nítido o movimento rápido e contínuo das situações" ${ }^{117}$ Da mesma maneira, em As Mambembadas, Bojunga não tinha preocupação com os detalhes técnicos da apresentação da peça, o que foi motivo de julgamento:

Teve gente que me disse que eu tinha escolhido um jeito suicida de apresentar o meu trabalho. Assim, sem iluminação, sem divulgação, sem parceiros, sem cenários, sem contra-regra. Essa opinião me surpreendeu: nunca tinha pensado que a maneira escolhida de apresentar o primeiro projeto da Casa podia parecer suicida.

Quando eu arquitetei o projeto, eu tinha resolvido que as experiências de palco e de livros da Casa Lygia Bojunga iam ser, na medida do possível, artesanais, 'feitas à mão'. E no momento nada me pareceu tão 'feito à mão' quanto mambembear pelo Brasil, levando de bagagem menos de cinco metros de crochê. ${ }^{118}$

Entende-se, portanto, que, a partir da criação da editora Casa Lygia Bojunga, a artista tem como grande objetivo tornar essa experiência editorial uma oportunidade de construir uma editora diferenciada, comparando a experiência dessa construção à simplicidade das experiências que teve ao encenar Livro - um encontro. Ao passo que as editoras se preocupam com prazos, detalhes, quantidades e vendas (e, para todas essas metas serem cumpridas, as obras são feitos por meio do processo industrial), a Casa Lygia Bojunga preocupa-se com a técnica e o ritmo artesanal, que fazem parte da essência não apenas da autora, mas também de sua obra. Dessa forma, pode-se afirmar que Bojunga tem um grande zelo pela sua técnica, pela sua forma de fazer literatura e, consequentemente, pela sua maneira de representar. Como a autora compara esse cuidado com a editora à simplicidade de suas Mambembadas, percebe-se que essa relação entre Mambembe e inovação - no caso de Lygia, na construção de uma editora diferenciada - também é encontrada na obra de Artur Azevedo:

\footnotetext{
${ }^{116}$ BOJUNGA, Lygia. Feito à mão. 4. ed. Rio de Janeiro: Casa Lygia Bojunga, 2008, p. 116.

${ }^{117}$ CELESTINO, Phelippe; MARTINS, Ferdinando. Uma quimera quase real: a burleta $O$ Mambembe de Arthur Azevedo e José Piza. PÓS: Revista do Programa de Pós-graduação em Artes da EBA/UFMG. v.8, n.15: mai, 2018. Disponível em: https://eba.ufmg.br/revistapos.

${ }^{118}$ BOJUNGA, Lygia, op. cit, p.118.
} 
O Mambembe correspondia à esperança de uma geração ávida pela realização de um teatro literário e de apuro estético. Se havia esperanças do estabelecimento do Teatro Municipal (tão sonhado por Azevedo, que morre sem vê-lo realizado), estas ainda se mostravam longas e distantes. Restava apostar em alguma atitude mais imediata, motivada por um fenômeno ousado e, minimamente, inovador. ${ }^{119}$

Além disso, o Teatro Mambembe apresenta-se como próprio tema, visto que o movimento da itinerância que o caracteriza é um de seus destaques:

O tema mambembe constitui e contempla todas as ações da peça: tudo gira em torno do que é teatral e itinerante. Os encontros, as despedidas, as confusões, as peripécias etc. Tudo sempre ocorre no movimento da chegada e da partida. ${ }^{120}$

Lygia Bojunga Nunes, no capítulo As Mambembadas, faz o mesmo, ao pensar no seu espectador - ela o chama de "Alguém" -, antes de subir ao palco:

É um Alguém que, lá pelas tantas, interrompe as intermináveis tarefas de todo dia e - lutando com o tráfego, correndo pra pegar uma condução, pedalando uma bicicleta, enfrentando um temporal, pulando cedo da cama (uma vez ou outra eu apresentei o meu número às nove da manhã) - enfrenta toda uma mão-de-obra pra ver uma mulher sozinha num palco e, ainda por cima, uma mulher que não é famosa (...)

(...) E entro em cena com a vontade firme de sintonizar com esse Alguém. Quero que o nosso encontro justifique pra ele a mão-de-obra enfrentada. ${ }^{121}$

O "Alguém" criado pela autora refere-se ao público de quem ela imagina o trajeto até o teatro em que ela irá se apresentar para que aconteça o encontro entre escritora-atriz e público. Até o espetáculo mambembe ocorrer de fato, Bojunga imagina todas as peripécias, as idas e vindas do público, para chegar até ela. Essa itinerância do público ligada à itinerância do cotidiano é um assunto que perpassa a obra de Lygia Bojunga, porém em relação à própria vida da autora: sabe-se que Lygia Bojunga, por muito tempo, dividiu sua vida entre Rio e Londres, inclusive escreveu um livro em que relata essa experiência ( $O$ Rio e eu), sendo assim, a artista sempre teve uma inclinação para a itinerância, o que é mostrado nessa obra como um todo, não apenas no capítulo As Mambembadas. Essa inclinação para a itinerância também é percebida em Feito à mão, pois, além de ser uma obra que explica o processo artesanal pelo qual a autora gostaria que todos os exemplares tivessem sido publicados, é uma obra que retrata, na maioria dos capítulos, um espaço do qual a autora gosta muito - espaço esse onde já esteve uma ou mais vezes - e que, em alguma medida, tem relação com sua

\footnotetext{
${ }^{119}$ CELESTINO, Phelippe; MARTINS, Ferdinando. Uma quimera quase real:a burleta $O$ Mambembe de Arthur Azevedo e José Piza. PÓS: Revista do Programa de Pós-graduação em Artes da EBA/UFMG. v.8, n.15: mai, 2018. Disponível em: https://eba.ufmg.br/revistapos, p.8.

${ }^{120}$ Ibid., p.8.

${ }^{121}$ BOJUNGA, Lygia. Feito à mão. 4. ed. Rio de Janeiro: Casa Lygia Bojunga, 2008, p. 128 e 129.
} 
escrita, tanto que se pode verificar isso já na maior parte dos títulos dos capítulos: Crow's nest, Uma minha casa, Boa Liga, Os mercados do México, As Mambembadas (não são um lugar, mas levaram a autora a vários lugares do país), Numa rua de Istambul.

Essa movimentação caracteriza o Teatro Mambembe e proporciona à obra da autora um universo em que a itinerância da vida e a itinerância do teatro se mesclam.

Explicitamente, também, a autora, em alguns Pra você que me lêe, faz menção ao Teatro Mambembe.

*Em o O Rio e eu, após contar sobre algumas dificuldades de criar sua editora e de referir-se às suas obras como seus filhos, ela afirma:

$\mathrm{Na}$ realidade, tenho vinte e não dezoito livros publicados. Mas dois desses são adaptações teatrais que fiz de Nós Três e $O$ Meu Amigo Pintor: os personagens são exatamente os mesmos; e a minha intenção primeira era reunir na Casa todos os meus per-so-na-gens. Numa outra etapa pretendo criar uma pequena coleção de teatro, incluindo não só essas duas adaptações, como também dois monólogos que encenei em meu projeto d'As Mambembadas. Mas isso é só depois que eu acabar os livros que estão há tanto tempo aguardando minha volta.... ${ }^{122}$

*Em Livro - um encontro, Lygia inicia o Pra você que me lê falando sobre suas apresentações de "Livro - eu te lendo":

\begin{abstract}
Naquela noite, quando subi ao palco para a primeira apresentação de 'livro' (o coração disparado, tamanha a emoção de acordar o meu eu-atriz, depois do sono profundo em que caiu durante anos), eu não tinha a menor ideia de que estava começando ali uma das experiências mais enriquecedoras que já tive na vida: um projeto de trabalho que me levou a percorrer inúmeros caminhos deste Brasilzão: um projeto de trabalho onde exponho, de maneira teatralizada, nos cinco monólogos que apresentei, intermitentemente, ao longo dos anos, diversas facetas do intenso relacionamento que sempre mantive com os livros. Chamei esse projeto de As Mambembadas", e, se você me conhece de outros encontros, já deve ter se interado dele em algum dos meus livros, ou em alguma das minhas apresentações. ${ }^{123}$
\end{abstract}

Ademais, a autora, desde suas primeiras obras, apresenta, por meio de recursos teatrais utilizados em sua escrita, essa paixão pelo Teatro Mambembe. A seguir, algumas obras em que a temática e os recursos desse tipo de teatro são utilizados.

\title{
5.2 TEATRO ITINERANTE: OS COLEGAS
}

\footnotetext{
${ }^{122}$ BOJUNGA, Lygia. O Rio e eu. Rio de Janeiro: Casa Lygia Bojunga, 2. ed. 2005, p. 92 e 93.

${ }^{123}$ BOJUNGA, Lygia. Livro - um encontro. Rio de Janeiro: Casa Lygia Bojunga, 6. ed. 2007, p.94.
} 
O Teatro Itinerante manifesta-se por meio da não permanência em um mesmo espaço por um período grande de tempo. Nesse sentido, Os colegas é uma obra que apresenta essa temática que está relacionada ao caráter fabular da obra, como será analisado a seguir.

Os colegas narra a história de dois cachorros de rua (Virinha e Latinha), uma cadela de raça (Flor-de-lis), um urso fugido do Zoológico (Ursíssimo Voz de Cristal) e um coelho abandonado (Cara-de-pau) que andam em grupo, são felizes, porém têm muitas dificuldades de sobrevivência por não trabalharem. Em um tom lúdico, as desigualdades sociais são tratadas de maneira sutil, metaforizadas: logo no começo da obra, há a cena dos dois vira-latas brigando por um osso, entretanto tornam-se amigos no momento em que concordam sobre como um menino que estava passando nesse momento estava assobiando um samba de modo errôneo. Essa mesma perspectiva musical levou os cachorros não só a dividirem o osso, mas também a comporem e divulgarem a sua primeira música juntos: "Dispostos a mostrar o samba pra todo mundo, saíram pela praia cantando em altos brados e batucando nas caixas de fósforos que tinham encontrado na areia." 124

Nessa passagem inicial de Os colegas, o improviso e o espetáculo itinerante já anunciam a forma estética do Teatro Itinerante como maneira de mostrar a vida de dificuldades desses personagens, que, no entanto, tentam superá-la por meio da arte a ser apresentada ao público. Outra passagem da obra que demonstra essa ideia é a cena em que Virinha, Latinha e Flor encontram Ursíssimo Voz de Cristal, que havia saído do seu trabalho e da sua casa no Zoológico para conhecer o mundo, já que haviam lhe dito que este era um "lugar ótimo". Então, os três amigos resolveram levá-lo até um circo para conhecer um dos lugares que faziam o mundo ser tão bom. Assim, há a descrição detalhada do circo. É importante destacar que cada ser, seja humano ou animal, apresenta uma característica que transforma em arte o que não é encontrado no Jardim Zoológico, espaço considerado, nessa obra, o de trabalho formalizado dos animais.

Esse universo do trabalho artístico permeia a obra toda, sempre apontando para o caráter itinerante, o que pode ser visto, por exemplo, após o grupo conseguir construir uma casa singela, ficando tão feliz que decide montar um bloco de carnaval com materiais acessíveis, o que demonstra, mais uma vez, o caráter de improviso, típico do Teatro Itinerante:

\footnotetext{
${ }^{124}$ BOJUNGA, Lygia. Os colegas. 52.ed. Rio de Janeiro: Casa Lygia Bojunga, 2014, p.14.
} 
Virinha e Latinha resolveram trabalhar juntos, e partiram pra fazer o que vinham fazendo desde que se viram sozinhos no mundo: revirar latas de lixo.

(...)

E conforme ia achando coisas que serviam ia gritando pro companheiro:

-Achei umas bolas de pingue-pong furadas!

-Achei umas escovas de dente velhas!

-Achei barbante!

-Achei umas penas de galinha!

-Achei bola de gude!

-Achei caixa de sapato vazia.

Tudo servia. ${ }^{125}$

Nesse sentido, essa obra vai se construindo a partir da habilidade das personagens principais em elaborarem sambas e costurarem fantasias, estando sempre felizes por realizar esse tipo de trabalho, o que não era possível anteriormente: Virinha e Latinha eram dois cães de rua, portanto, não tinham trabalho; Flor-de-Lis era fugitiva, porque não gostava de ser cadela de madame, dessa forma também nunca teve de trabalhar; Cara-de-Pau, o coelho abandonado, cujo trabalho, ao fazer parte da turma, era recolher restos de verduras e de legumes em feiras; Ursíssimo Voz de Cristal era o único do grupo a ter tido um trabalho, era urso de Zoológico, porém abandonou seu local de trabalho em busca de conhecer as maravilhas do mundo, o que, implicitamente, demonstra que não existiam em seu universo laboral.

Não obstante, a vida à margem do trabalho tradicional colocava os personagens em uma posição de vadiagem, inclusive de animais a serem capturados pela carrocinha, que, nessa obra, é uma metáfora para o sistema prisional. Esse caráter de vadiagem pode ser observado em uma passagem em que a turma vai buscar Voz de Cristal, que teria voltado a trabalhar no Zoológico, porém não queria mais sair de lá por estar apaixonado pela girafa, que, ao ser convidada a fazer parte da trupe, respondeu:

- Só vagabundo é quem vive sem trabalhar! (...) - Não somos vagabundos e gostamos muito de trabalhar aqui porque nos tratam muito bem. Comemos na hora certa. Dormimos na hora certa. Passeamos na hora certa. Casamos na hora certa. Não pretendo nunca sair daqui e o meu noivo também não. ${ }^{126}$

Sendo assim, fica clara a divisão entre o grupo de animais que trabalham em troca de uma vida regrada e estável em oposição ao que não trabalha ou o faz de modo informal e esporádico e, por isso, não tem estabilidade.

\footnotetext{
${ }^{125}$ BOJUNGA, Lygia. Os colegas. 52.ed. Rio de Janeiro: Casa Lygia Bojunga, 2014, p.36.

${ }^{126}$ Ibid., p.115.
} 
Essa discussão sobre o trabalho, que permeia a obra toda, volta à tona nas últimas páginas do livro, após o grupo de amigos terem passado por diversos contratempos e terem chegado, juntos, a uma conclusão:

'Não dá mais pé ficar sem trabalhar.'

- Porque a verdade é que a gente tá ficando cansado desse negócio de fugir, de ter que arriscar a vida todo dia, de ter que viver sem saber se vai arranjar comida ou não - disse Virinha.

(...)

- Mas que trabalho a gente vai arranjar? - Flor quis logo saber. ${ }^{127}$

Dessa maneira, surgem algumas ideias entre os personagens, porém que reforçam os problemas de se seguir determinada área de trabalho, devido à ausência, respectivamente, de habilidade técnica, de perfil de trabalho e de reconhecimento artístico perante o mercado:

- Será que os Garcia não nos dão um emprego na 'Companhia Tatu Túneis’ que eles estão fazendo? - perguntou Latinha.

Virinha torceu o nariz:

- A gente não entende nada de engenharia: não vai dar certo!

- Quem sabe nós vamos pro Zoo? - arriscou Cara-de-Pau. Todo mundo diz que lá eles tratam um bocado bem dos bichos.

Latinha se impacientou:

- Jardim Zoológico não aceita cachorro nem coelho pra trabalhar, seu bobalhão!

- Acho que a gente deveria tentar vender os sambas de Virinha e Latinha - sugeriu Flor.

A impaciência de Latinha virou desânimo:

- Ora, nós já tentamos tantas vezes! Mas tudo quanto é comprador de samba vai logo dizendo: '- É samba de cachorro? Então nem quero ver: samba de cachorro não pode ser bom.' 128

Essa passagem, portanto, reforça que os personagens, não tendo opção de trabalhos considerados formais, terão de sobreviver por meio de atividades que os tornem felizes:

Foi quando Virinha teve uma de suas ideias:

- Vamos trabalhar no circo?

(...)

- Bom, eu bolei isso porque de repente me lembrei do sucesso que o nosso bloco fez no carnaval. E acho que a gente poderia dar um bom número de circo se caprichasse nas fantasias e mandasse aquela brasa no batuque e nos passos. ${ }^{129}$

Considerando que toda a turma, incluindo o Ursíssimo Voz de Cristal que, novamente, foge do Zoo, começa a trabalhar no circo, além de a obra terminar com uma atmosfera mambembe, percebe-se que essa primeira obra de Bojunga tem duplamente um caráter fabular. Duplamente é o termo utilizado aqui para destacar que é conceituado de modos

\footnotetext{
${ }^{127}$ BOJUNGA, Lygia. Os colegas. 52.ed. Rio de Janeiro: Casa Lygia Bojunga, 2014, p.122.

${ }^{128}$ Ibid., p.122-123

${ }^{129}$ Ibid, p. 123.
} 
diferentes pela literatura e pelo teatro; porém, a escritora consegue unir ambos os conceitos. Para isso, é importante compreender as definições utilizadas em cada área. No Dicionário de Termos Literários, o termo é definido desta maneira:

Fábula - Lat. fabula, conversação, narrativa, relato.

Narrativa curta, não raro identificada com o 'apólogo' e a 'parábola', em razão da moral, implícita ou explícita, que deve encerrar, e de sua estrutura dramática. No geral, é protagonizada por animais irracionais, cujo comportamento, preservando as características próprias, deixa transparecer uma alusão, via de regra satírica ou pedagógica, aos seres humanos. Escrita em versos até o século XVIII, em seguida adotou a prosa como veículo de expressão. ${ }^{130}$

Todavia, no Dicionário de Teatro, discute-se a contradição de noção de fábula, visto que o emprego desse termo
deixa depreender duas concepções opostas do lugar da fábula:
- como material anterior à composição da peça;
- como estrutura narrativa da história.
Esta dupla definição confirma a oposição dos termos inventio e dispositivo da retórica ou story (história) oposta a plot (intriga) da crítica anglo-saxônica.
Compor a fábula (no sentido 2) é, para o autor dramático, estruturar as ações - motivações, conflitos , resoluções, desenlace - num espaço/tempo que é 'abstrato' e construído a partir do espaço/tempo e do comportamento dos homens. A fábula textualiza as ações que puderam ocorrer antes do início da peça ou que terão sequência após a conclusão da peça. ${ }^{131}$

Para ser mais claro em relação à fábula como matéria, são destacados dois aspectos: a relação de fábula e assunto e a junção das ações realizadas. Sobre o primeiro deles, é afirmado que:

\begin{abstract}
A partir de qualquer texto dramático pode-se portanto reconstituir a fábula como uma sequência de motivos ou temas que nos são comunicados no decorrer da obra sob a forma específica de assunto. Esta distinção atinge sua formulação mais sistemática na obra dos formalistas russos: 'A fábula se opõe ao assunto que constituído pelos mesmos acontecimentos, mas ele respeita sua ordem de aparição na obra e a sequência das informações que no-las designam [...] Em suma, a fábula é o que se passou efetivamente; o assunto é a maneira pela qual o leitor tomou conhecimento disto (TOMASCHÉVSKI, in TODOROV, 1965: 268) ${ }^{132}$
\end{abstract}

Essa "sequência de motivos ou temas que nos são comunicados no decorrer da obra sob a forma específica de assunto", em Os colegas, aparece por meio da organização dos capítulos da obra, que, além de curtos, tais como minifábulas, apresentam títulos que sugerem uma ordem temporal, tais como II. É tempo de carnaval, III. A grande farra, IV. Quarta-feira

\footnotetext{
${ }^{130}$ MOISES, Maussad. Dicionário de termos literários. São Paulo: Cultrix, 2013, p.187.

${ }^{131}$ PAVIS, Patrice. Dicionário de teatro. São Paulo: Perspectiva, 2015, p.157.

${ }^{132}$ Ibid., p. 158.
} 
de cinzas. Assim sendo, esse aspecto da relação entre fábula e assunto é respeitado pela autora.

Ainda tratando da fábula como matéria, acerca da junção das ações realizadas, o Dicionário de Teatro afirma que: "a fábula descreve 'os atos das personagens, e não as personagens em si." ${ }^{133}$ Percebe-se, em Os colegas, que a história é construída por meio da narração das ações das personagens, não de suas descrições. Um exemplo nítido disso é a apresentação da personagem Flor-de-lis, pois ela mesma conta sua história narrando acontecimentos. Lygia Bojunga toma o cuidado de, graficamente, separar essa história da narrativa central da obra:

Figura 2 - A história de Flor-de-Lis

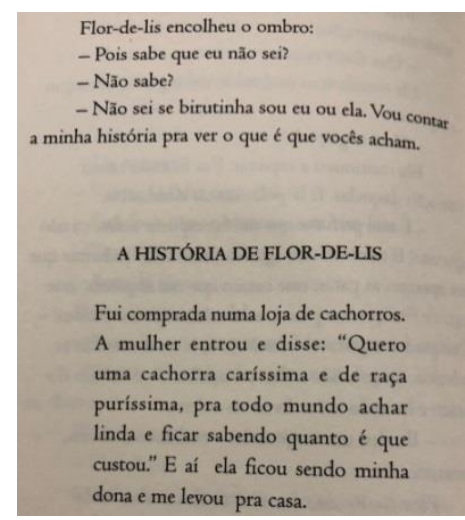

Fonte: Lygia Bojunga (2014)

Esse conjunto de ações, seja da narrativa central ou das mininarrativas contadas pelas personagens, colocadas em uma determinada sequência, revela o caráter fabular da obra. Assim, sob uma perspectiva da narrativa principal, a obra inicia a estrutura narrativa por meio de indícios - como o trabalho manual, composição de sambas - que são retomados mais ao fim da obra, porém com outro tipo de valorização. Isto é, as ações são estruturadas de modo linear, com um trajeto objetivo que culmina em um desfecho que se amarra a algumas ideias centrais já narradas anteriormente. Os colegas iniciam a obra com a composição de um grupo nômade e encerram-na com esse mesmo grupo como nômade, porém com trabalho garantido no circo.

Dessa forma, considerando os conceitos teatrais de fábula já comentados, há a mistura deles ao conceito literário de fábula. Este, em Os colegas, pode ser notado graças às personagens que são animais com ações humanas e, de certa maneira, passa-se uma moral da

\footnotetext{
${ }^{133}$ PAVIS, Patrice. Dicionário de teatro. São Paulo: Perspectiva, 2015, p.158.
} 
história relacionada ao trabalho artístico, mambembe como possibilidade de sobrevivência e de felicidade, não de marginalidade.

\subsection{TEATRO CIRCENSE: CORDA BAMBA}

Nessa obra, o Teatro Circense já se revela no próprio tema, pois é narrada a história de Maria, uma criança artista circense que, após a morte de seus pais, que trabalhavam em um circo, vai morar com a avó rica. Não conseguindo se adaptar à nova vida, Maria passa por um processo de reativação de suas memórias, que é apresentado na obra por meio de transições lúdicas que a menina faz ao percorrer a corda bamba da janela de seu quarto na casa da avó até o prédio em frente a essa janela. Após a transição, haveria portas por trás das quais estavam guardadas as memórias e as histórias da protagonista. Esse deslocamento de um universo para o outro sempre ocorre por meio da corda bamba, que retira a artista circense de sua realidade atual. Esse deslocamento espacial, típico do nomadismo do Teatro Itinerante e Circense, é mostrado, também, ao longo da obra, pela oposição entre a organização de uma vida não nômade, como a da avó de Maria, e a organização de uma vida itinerante, como a de Maria no circo.

Antes de se analisar esse deslocamento espacial, é importante realizar a aproximação entre Teatro Mambembe e Circense no que se concerne ao espaço e à duração dos espetáculos:

O teatro mambembe, (...) cujas companhias ou grupos são itinerantes, ou seja, saem viajando por aí, armam seu palco em diversos lugares como uma praça, um parque, e se apresentam. É parecido com o que faz o circo. As peças apresentadas em condições assim geralmente são cômicas e curtas (...) ${ }^{134}$

Considerando que Corda bamba é uma obra em que há constantes variações de espaços, sejam eles reais ou imaginários, e em que há cenas circenses curtas - entre elas, no início da narrativa, Maria faz uma apresentação na corda bamba em uma festa de aniversário na casa da avó; ou mesmo os bastidores e o início do número circense responsável pela morte dos pais da menina -, pode-se notar que essa obra, por ela mesma, já representa o próprio caráter itinerante do circo, bem como referências aos seus números de pouca duração.

\footnotetext{
${ }^{134}$ RÁDIO E TELEVISÃO EDUCATIVA DO PARANÁ. O circo e a tradição mambembe. Disponível em: http://www.paranaeducativa.pr.gov.br/2016/06/3968/O-circo-e-a-tradicao-do-teatro-mambembe.html. Acesso em: 10 jun. 2019.
} 
Com relação à oposição que se percebe entre vida circense e não circense, há várias passagens na obra que as explicita. Logo no primeiro capítulo, quando Maria chega à casa da avó, essas oposições baseiam-se em:

a) Horários agendados: a vida no circo e seus respectivos compromissos dependem, dentre outros aspectos, da relação entre quantidade de público e continuidade ou não da temporada em determinado local, visto que esta pode ser mais curta em uma região, se não houver público. Além disso,

\begin{abstract}
Diferentemente de comunidades nômades, como os ciganos, com os quais às vezes são confundidos, os circenses possuem itinerário predeterminado pelo lugar do próximo espetáculo. E este local, muitas vezes, só fica sendo conhecido no dia da mudança, isso porque deve-se antes resolver questões como a escolha do terreno e o respeito às normas de cada cidade, podendo sempre dar algo errado na última hora e ser preciso sair à procura de outro lugar. ${ }^{135}$
\end{abstract}

Assim sendo, ao contrário de uma organização social não nômade, como a da família da avó de Maria, dificilmente um artista de circo pode prever com muita antecedência horários marcados, como é visto nesse trecho em que D. Maria Cecília questiona Barbuda:

- Eu entendi, eu entendi tudo, mas você podia ter dito 'vamos chegar no dia tal, na hora tal'.

- Mas é que o circo tá fazendo excursão, a gente ainda não sabia o dia certo que chegava aqui no Rio. ${ }^{136}$

b) Espaço e identidade: além da preocupação com o macro espaço, ou seja, o lugar onde o circo será montado, sabe-se que o espaço onde os espetáculos circenses são apresentados é o picadeiro. Logo, é nesse espaço e em seus entornos que a identidade de um artista circense será construída. Desse modo,

A identidade circense como qualquer outra identidade social, é imbuída da negação do não-circense. O conceito de Barth (2000) de "identidades contrastivas" diz que quando uma pessoa ou grupo se afirmam como tais, o fazem como meio de diferenciação em relação a alguma outra pessoa ou grupo com que se defrontam; é uma identidade que surge por oposição, implicando a afirmação de nós diante dos outros, jamais se afirmando isoladamente. O circo é aqui entendido como diferença e nos permitirá captar a articulação entre o espaço e o tempo fronteiriço e doméstico da cultura (Babha, 2003). ${ }^{137}$

135 IWATA, Tatiana; MARANHA, Fernanda. Circo: reelaboração de uma cultura. Revista Psico-USP. Disponível em: http://www.ip.usp.br/revistapsico.usp/index.php/arte-e-cultura/12-circo-reelaboracao-de-umacultura. Acesso em: 30 ago. 2018.

${ }_{136}^{13}$ BOJUNGA, Lygia. Corda bamba. 13. ed. Rio de Janeiro: Casa Lygia Bojunga, 2009, p.12.

${ }^{137}$ MARTINS, Taiana Renata; ALVAREZ, Gabriel. A identidade circense, seus símbolos e rituais sob a lona. Reflexões sobre o circo e suas performaces. Disponível em: https://eiap2011.files.wordpress.com/2011/05/taiana-martins-gt-1.pdf .Acesso em: 05 mai. 2019. 
Partindo dessa ideia, o artista circense compõe sua identidade em oposição à identidade de comunidades não circenses, o que pode ser um processo solitário, quando precisam compô-la longe do circo, como acontece com a protagonista de Corda bamba. Assim sendo, a obra apresenta a oposição do espaço circense e do sedentário justamente para mostrar o processo identitário de Maria. Essa ideia pode ser resumida nesta fala de D. Maria Cecília: “- Não, não! A minha casa não é circo! E a Maria não é mais uma equilibrista!”138

O novo lar de Maria não é o circo, muito menos a avó da menina permite que esta mantenha seus hábitos circenses, forçando a criança a não ser mais quem ela costumava ser: uma equilibrista. Logo, a vontade de continuar sendo parte do circo em um espaço que não a comporta como artista circense a faz permutar para o universo do imaginário em que sua história, ligada ao circo, lhe dá sentido de vida.

c) Organização: uma sociedade sedentária apresenta o mínimo de atenção com a organização de suas ferramentas e objetos, o que para um artista circense não é uma preocupação fundamental, visto que está sempre se mudando. A diferença de pensamento entre uma estrutura social e outra é captada neste trecho:

- Vocês não pretendem largar isso tudo? Sacola, embrulho, corda? - Mas fechou a cara quando viu Maria guardando tudo debaixo da cama: - Que é isso, Maria? Tem armário, cômoda, mesa, tem tudo que é preciso pra você guardar suas coisas!

- É costume - Barbuda explicou -, é que a gente sempre dorme meio apertada, sem muito lugar pra nada.

- Mas a minha casa não tem nada que ver com o circo! Nem você vai querer fazer aqui o que fazia lá, não é, Maria?

Maria olhou pro chão. D. Maria Cecília resolveu fazer um ar de brincadeira:

- E se você guarda tudo aí, como é que depois você e o Quico vão brincar de esconde-esconde embaixo da cama? ${ }^{139}$

Além dessas referências de oposição de espaços no primeiro capítulo, há outra muito importante em Conversa de orelhão, quando Barbuda e Maria conversam pelo telefone sobre a educação da menina.

d) Educação no circo:

As crianças sempre às vistas de todos, são educadas para saberem desde cedo todas as técnicas para a armação da lona. Desde a escolha do terreno até a segurança dos aparelhos. Passam também por um processo de educação corporal de observação e repetição influenciado pelos pais, tios, irmãs, irmãos, cunhados artistas. Com o tempo cada um descobre sua habilidade. Uma vez descoberta inicia-se o trabalho de criação de número para integrar o espetáculo. Mas mesmo antes de integrarem uma cena com seus números, as crianças são envolvidas em alguma parte da produção do

\footnotetext{
${ }^{138}$ BOJUNGA, Lygia. Corda bamba. 24. ed. Rio de Janeiro: Casa Lygia Bojunga, 2009, p.17.

${ }^{139}$ Ibid., p. 23.
} 
espetáculo para que desde cedo interajam com esse ambiente de criação artística com o objetivo de preparar-se para a chegada do momento de subir ao palco para fazer a própria apresentação. Eis uma mudança de status, um deslocamento de função na estrutura social que o circense vive. ${ }^{140}$

Com base nisso, a educação circense objetiva a sobrevivência do circo e da tradição circense, sendo, por isso, ensinadas às crianças todas as etapas que envolvem o espetáculo, desde a montagem do picadeiro até o desenvolvimento de sua arte. Nesse universo, portanto, não faz sentido o conteúdo programático regular das escolas formais, como se pode notar neste trecho de diálogo entre Maria e Barbuda:

- Eles acharam que eu tô atrasada pra minha idade.

- Atrasada? Atrasada como? Você não mostrou como você escreve, como você lê, como você desenha, como você equilibra?

- Bom...

- Você não contou como é que todo dia a sua mãe tomava a sua lição, fazia você estudar?

(...)

- Eles falaram lá na escola que na minha idade eu já tinha que saber fatoração, já tinha que saber múltiplos e divisores, já tinha que.... ${ }^{14}$

Além de a educação ser marcada pelos espaços distintos, a condição socioeconômica também sugere diferenças grandes.

e) Situação econômica: com algumas exceções, sabe-se que o circo, sobretudo o familiar, não é um meio pelo qual se enriquece financeiramente. Dessa forma, Corda bamba demonstra as diferenças de classe social entre Márcia e Marcelo, pais de Maria. Márcia é filha de D. Maria Cecília, mulher que sempre teve excelente condição financeira, nunca precisou trabalhar; porém, Marcelo já trabalhava como equilibrista em circo pequeno, mas, como pagavam pouco, ele treinava números arriscados para conseguir um emprego um pouco mais rentável. Apesar dessas diferenças, os dois se amavam, mas tiveram problemas para se casarem: “- Imagina se eu vou deixar a nossa filha casar com ele?! Imagina se eu vou deixar ela viver num andaime, ou numa corda bamba, ou numa, sei lá, numa dessas coisas que balançam?" 142

As referências citadas por D. Maria Cecília referentes à corda bamba demonstram a preocupação dela com a instabilidade que a filha teria, não apenas nas atividades circenses, de desequilíbrio, mas também em termos de sobrevivência financeira.

\footnotetext{
${ }^{140}$ MARTINS, Taiana Renata; ALVAREZ, Gabriel. A identidade circense, seus símbolos e rituais sob a lona. Reflexões sobre o circo e suas performaces. Disponível em: https://eiap2011.files.wordpress.com/2011/05/taiana-martins-gt-1.pdf Acesso em 05 mai.2019.

${ }^{141}$ BOJUNGA, Lygia. Corda bamba. 24. ed. Rio de Janeiro: Casa Lygia Bojunga, 2009, p.39.

142 Ibid., p.89.
} 
Outra passagem que mostra essas diferenças é a que retrata o presente de aniversário que a avó de Maria deu a ela:

O presente era uma velha. Mas não era de acrílico nem de borracha, era uma velha de verdade, gente de carne e osso.

A menina olhou pra avó.

- É isso mesmo, minha boneca, essa velha é pra você. Quando você quiser ouvir história é só mandar: história! E pronto, ela conta.

(...)

A menina chegou pertinho da avó e cochichou:

- Mas, vó, gente se compra?

- Quem tem dinheiro feito eu compra tudo.

(...)

- Gente custa caro?

- Depende. Tem uns que custam bem caro (olhou de rabo de olho pros retratos [dos ex-maridos]). Essa aí custou baratinho.

- Mas, vó, tem loja pra comprar gente?

- Não, minha boneca, não tem loja, não.

- Então onde é que você comprou ela?

- Lá mesmo onde ela morava.

- E onde é que ela morava?

- Num lugar muito pobre. ${ }^{143}$

Nesse trecho, além de o espaço da riqueza ser claramente explicitado como o espaço do poder ilimitado, o espaço da pobreza é retratado como o espaço da reificação do ser humano.

\subsection{TEATRO DE RUA: A CASA DA MADRINHA}

Logo no início da obra, o protagonista, Alexandre, é apresentado durante o espetáculo que faz na rua com o Pavão. Por isso, pode-se afirmar que $A$ casa da madrinha inicia-se com um Teatro de Rua, visto que este é um "Teatro que se produz em locais exteriores às construções tradicionais: rua, praça, mercado, metrô, universidade etc." 144

O Teatro de Rua, por ter caráter itinerante, faz parte do mesmo universo do Teatro Mambembe, principalmente no que se diz respeito à simplicidade por meio da qual é representado, sem muitos recursos. Essa escassez de recursos aparece no espetáculo de Alexandre, pois este chama a atenção do público com uma caixa de sorvete "(só que ao invés de gelo e sorvete, a caixa tinha colher, garfo e faca: tinha também um toco de lápis, um livro de história, uma caneca e uma panela)." ${ }^{145}$ e, ao invés de colocar uma música, ele mesmo a

\footnotetext{
${ }^{143}$ BOJUNGA, Lygia. Corda bamba. 24. ed. Rio de Janeiro: Casa Lygia Bojunga, 2009, p.109-111.

${ }^{144}$ PAVIS, Patrice. Dicionário de teatro. São Paulo: Perspectiva, 2015, p.385.

145 NUNES, Lygia Bojunga. A casa da madrinha. 9. ed. Rio de Janeiro: Agir, 1986, p.9.
} 
canta: "O que Alexandre queria mesmo era um rádio, uma vitrola, um som qualquer pra tocar, mas como ele não tinha nada, tinha mesmo que cantar: sem música o Pavão não podia dançar." ${ }^{146}$ Além disso, o menino utiliza um lenço como venda para tampar a visão do Pavão, antes de realizar uma mágica.

Outro elemento ligado ao universo do Teatro Mambembe e ao Teatro de Rua que essa obra mostra é a similaridade entre Alexandre e um saltimbanco: “ é o termo genérico para malabarista, pelotequeiro, embusteiro, charlatão, farsante, pregoeiro, arranca-dentes, paradista." 147

A referência pejorativa de um saltimbanco feita a Alexandre pode ser notada quando o público desconfia algumas vezes do protagonista:

\footnotetext{
- E se a gente paga e depois o pavão não é bonito assim que nem dizem?

E uma mulher que tinha um bruto dente de ouro quis saber:

- E se ele não faz mágica? E se ele não dança?

O sujeito resolveu:

- Dinheiro anda difícil de arranjar, garoto; a gente só pode gastar com coisa muito cem por cento. Primeiro o pavão aparece e faz tudo o que sabe fazer, depois a gente paga. ${ }^{148}$
}

Entretanto, como Alexandre sobrevive do que arrecada com os shows, portanto a ideia é sugerir sua situação de pobreza, o menino é quem desconfia do público: “Alexandre não gostou, já conhecia aquela história: o show acabava, eles iam saindo como quem está chegando, ficava tudo por isso mesmo. Fez cara feia: - Não tô tapeando ninguém, o que eu disse que o Pavão faz, ele faz mesmo." 149

O protagonista também é retratado como um saltimbanco, pois esse tipo de artista oferecia suas apresentações em troca de formas de ganhar dinheiro: "O saltimbanco era um artista popular que, nas praças públicas, quase sempre em cima de um tablado, fazia demonstrações de habilidades físicas, de acrobacias, de teatro improvisado, antes de vender ao público objetos variados, pomadas ou medicamentos." 150

Nesse sentido, Alexandre é um saltimbanco porque os shows que faz com o Pavão são a única maneira de ele obter dinheiro e alimentos para sobreviver. Por essa razão, a interação entre Alexandre, Pavão e público é importante não apenas para que haja o pagamento do

\footnotetext{
${ }^{146}$ NUNES, Lygia Bojunga. A casa da madrinha. 9. ed. Rio de Janeiro: Agir, 1986, p.11.

${ }^{147}$ PAVIS, Patrice. Dicionário de teatro. São Paulo: Perspectiva, 2015, p.349.

${ }^{148}$ NUNES, Lygia Bojunga. A casa da madrinha. 9. ed. Rio de Janeiro: Agir, 1986, p.11.

${ }^{149}$ Ibid., p.10.

${ }^{150}$ PAVIS, op. cit., p.349.
} 
espetáculo, mas também para que a apresentação de rua tenha a participação da plateia. A contribuição do público com o número de Alexandre é outra característica de Teatro Itinerante, especialmente o circo, visto que os artistas circenses interagem uns com os outros no picadeiro, porém, na maioria dos casos, sempre estabelecendo uma triangulação com a plateia:

\begin{abstract}
A triangulação posiciona-se como uma técnica de interpretação, e, enquanto instrumental interpretativo, atribui determinadas características ao espetáculo teatral. Talvez, a principal, seja a de incluir o espectador no jogo cênico: o espetáculo não é feito PARA a platéia e sim, COM a platéia. ${ }^{151}$
\end{abstract}

Em A casa da madrinha, Alexandre dialoga o tempo inteiro com o público, inclusive pede a participação dele tanto na preparação: “-A senhora aí! Quer fazer o favor de vir amarrar o lenço pra ninguém ficar pensando que eu deixei uma frestinha?” ${ }^{152}$, quanto na realização do número: “- Quem é que vem puxar a pena? Vera levantou a mão e correu (só pra chegar pertinho de Alexandre). Puxou uma pena com muito cuidado e voltou pro lugar." 153

Além disso, o espetáculo realizado por Alexandre apresenta também caráter teatral por ser dividido em partes, tal como atos de uma peça. Uma dessas partes é uma mágica, que, por sua vez, remete ao universo circense.

Voltando à falta de confiança na imagem de saltimbanco do protagonista de $A$ casa da madrinha, pode-se dizer que não ocorreu apenas durante seu espetáculo, mas também durante uma conversa com Vera, uma amiga que o menino faz após o espetáculo e que tenta ajudá-lo pedindo aos pais que o hospedem na casa dela:

- É a casinha de ferramentas. Mas é uma casinha legal. O meu pai falou que, você querendo, podia dormir lá, mas que lá em casa não dava pé.

- Por quê?

- Bom, é que... - Suspirou e ficou quieta.

- Fala.

- É que, eles falaram que, pelo jeito, sabe? Pelo jeito você não é lá muito boa companhia pra mim.

- Por quê?

- Bom, o meu pai falou, quer dizer, os dois falaram, que você é assim, como é mesmo que eles falaram? ah, um menino diferente de mim.

- Diferente como?

- É que, bom, eles falaram que você é um menino largado.

- E quem é que disse isso pra eles? Quem?

- Por favor, não fica zangado. Eles falaram isso porque você tá viajando sozinho.

${ }^{151}$ BRITO, Rubens de Souza. O grupo de teatro Mambembe e o Circo Teatro. Sala Preta, v. 6, p. 79-85, 28 nov. 2006, p.82.

${ }^{152}$ NUNES, Lygia Bojunga. A casa da madrinha. 9. ed. Rio de Janeiro: Agir, 1986, p.12.

${ }^{153}$ Ibid., p. 12 . 
- Sozinho, não! Tô viajando com o Pavão.

- Pois é, eles acham que o pavão é muito bonito mas que é pouca companhia pra um garoto viajar. ${ }^{154}$

É interessante ressaltar que o significado dos nomes das personagens Alexandre e Vera reforça esse caráter saltimbanco da vida do garoto. Enquanto "Alexandre" significa "protetor do homem", "defensor da humanidade", ao mesmo tempo em que é uma menção a Alexandre, o Grande, ou seja, o consquitador, "Vera" significa "verdadeira", "franca". O nome de Alexandre pode ser compreendido de modo metafórico, pois a proteção dada à humanidade, considerando o objetivo do protagonista na narrativa, seria a do direito de sonhar e de buscar uma realidade ou vida melhor. Isto é, o sentido de "homem" ou de "humanidade" que deve ser protegido não é o sentido da racionalidade - este é representado por Vera -, mas o da fantasia, que remete ao universo lúdico, o mesmo alcançado pelos saltimbancos em suas apresentações teatrais. Portanto, tem-se, de um lado, um menino desbravador, que preserva o universo lúdico, seja por meio dos espetáculos com o Pavão, seja pela crença de que irá encontrar a casa mágica de sua madrinha; tem-se, de outro, uma menina obediente, que respeita os fatos, como os indicados pelos próprios pais.

Desde o primeiro capítulo percebe-se que a vida de saltimbanco de Alexandre é oposta à vida regrada de Vera. Alexandre tem uma mãe que passa o dia trabalhando com atividades domésticas remuneradas; irmãs que realizam atividades informais para contribuírem com a renda familiar; um pai alcoólatra e desempregado; um irmão que se mudou e pouco ajuda a família e um casebre no morro. Já Vera tem pais presentes, sendo o ofício do pai o de plantar flores, o que faz sua casa ser bastante florida.

Apesar das diferenças entre as personagens, o acesso à casa da madrinha é feito por ambos e de modo teatral, pois Vera e Alexandre criam em conjunto uma personagem e um cenário. A personagem, um cavalo, cujo nome é uma onomatopeia que remete a um grito Ah! - é o meio de transição entre a realidade e o imaginário. Por meio dessa personagem criada por ambos é que os dois conseguem acessar um espaço de transição, que é escuro, uma metáfora para os medos:

- De repente, de tanto falar no medo, ficaram com a impressão certinha que o medo estava bem perto; era só estender a mão que pronto: tocavam nele. Então Alexandre falou cochichando (para ver se o medo não ouvia):

- Parece que eu estou todo amarrado. É o medo que deixa a gente assim, não é?

- É.

\footnotetext{
${ }^{154}$ NUNES, Lygia Bojunga. A casa da madrinha. 9. ed. Rio de Janeiro: Agir, 1986, p.32.
} 
Os três se encolheram. Pra dar mais lugar pro medo, pra não encostarem nele. Ficaram assim um tempão. Depois Alexandre resolveu:

- Quer saber do que mais? Eu não deixo ele me amarrar, não deixo. - Se soltou de Vera e foi tateando em volta. - Aqui desse lado ele não está.

- Cuidado, Alexandre! ${ }^{155}$

O menino passa a procurar o medo para enfrentá-lo, até que criam um espaço fazendo do escuro um quadro-negro, que serve de fundo para os desenhos feitos com um giz que encontraram. Alexandre desenha uma porta, atravessam-na e chegam ao universo lúdico onde fica a casa da madrinha. Sendo assim:

o jogo só existe dentro de um sistema de designação, de interpretação das atividades humanas. Uma das características do jogo consiste efetivamente no fato de não dispor de nenhum comportamento específico que permitiria separar claramente a atividade lúdica de qualquer outro comportamento. $\mathrm{O}$ que caracteriza o jogo é menos o que se busca do que o modo como se brinca, o estado de espírito com que se brinca. O caráter lúdico de um ato não vem da natureza do que é feito, mas da maneira como é feito... O brincar não comporta nenhuma atividade instrumental que lhe seja própria. Ele tira suas configurações de comportamentos de outros sistemas afetivos comportamentais.' P. C. Reynold, 'Play, language and human evolution, citado por J. S. Bruner, Le développement de l'enfant - Savoir faire, savoir dire, Paris : P.U.F., 1983, p.223. ${ }^{156}$

É evidente, portanto, que no jogo que compõe o lúdico, a forma por meio da qual a autora o constrói passa a ser mais importante que o objetivo de Alexandre, que é o de encontrar a casa da madrinha, tanto que ele a encontra por acaso.

O desfecho da obra mostra um Alexandre que continua acreditando em um progresso de vida que, talvez, nunca ocorra:

\begin{abstract}
Alexandre pegou a chave e guardou no bolso:
- Que legal! Agora vou viajar com a chave da casa no bolso; não vou ter mais problema nenhum. Lembra o que o Augusto falou?

Vera fica olhando pra flor sem entender.

- Não lembra não, Vera: Eu te contei. Ele disse que no dia que eu botasse a chave da casa no bolso, o medo não ganhava mais de mim. - Riu. - Já pensou? Agora eu posso viajar toda a vida. Quando o medo bater eu ganho dele e pronto. ${ }^{157}$
\end{abstract}

Apesar de tudo aparentemente permanecer como desde o começo da narrativa, o garoto venceu o medo e assume que pode "viajar toda a vida". É interessante analisar esse trecho, pois ele pode significar tanto "viajar muito" quanto "viajar durante a vida inteira". Independentemente da interpretação, a personagem está pronta para os momentos em que o medo se personifique ("Quando o medo bater" é uma expressão que aparenta significar

\footnotetext{
155 NUNES, Lygia Bojunga. A casa da madrinha. 9. ed. Rio de Janeiro: Agir, 1986, p.12.

${ }^{156}$ BROUGÉRE, Gilles. A criança e a cultura lúdica. Rev. Fac. Educ. vol.24, n.2, São Paulo. July/Dec. 1998.

${ }^{157}$ NUNES, op. cit., p.94.
} 
"quando o medo aparecer", mas, pela frase que vem em seguida, nota-se que o verbo "bater" constrói seu significado no campo semântico da violência). Estando pronto para esse medo personificado, Alexandre sente-se confiante de que ganhará do medo nessa luta. Tem-se, portanto, a provável continuidade do estilo de vida de um saltimbanco, que continuará sobrevivendo por meio do Teatro de Rua. Porém, não se passa de probabilidade, visto que o final da narrativa fica em aberto.

Tendo sido analisados o Teatro Itinerante, o Teatro Circense e o Teatro de Rua, como forma de ilustrar o Teatro Mambembe, a seguir será analisado um tipo de teatro que se baseia em objetos: o Teatro de Animação. 
Depus a máscara e vi-me ao espelho. Era a criança de há quantos anos.

Não tinha mudado nada...

É essa a vantagem de saber tirar a máscara.

É-se sempre a criança,

O passado que foi

A criança.

Depus a máscara e tornei a pô-la.

Assim é melhor,

Assim sou a máscara.

E volto à personalidade como a um terminus de linha.

Álvaro de Campos

Todo mundo deve atuar no teatro de marionetes da vida e sentir o arame que nos mantém em movimento.

Arthur Schopenhauer

A nitidez é a conveniente distribuição de luz e de sombra.

Johann Goethe 


\section{TEATRO DE ANIMAÇÃO}

\subsection{TIPOS DE OBJETOS}

Etimologicamente, o termo "animação" origina-se do latim animatǐo, ōnis, cujo significado é "a qualidade de um ser animado, animação; ardor”.

Segundo o Dicionário Houaiss da Língua Portuguesa, a palavra “animação” significa:

s.f. ato ou efeito de animar(-se). 1 ação ou efeito de dar alma ou vida a 2 fig. A vivacidade, brilho 3 fig. sentimento de exaltação; alegria, entusiasmo 4 p.ext. atividade intensa; movimentação $\mathbf{5}$ técnica de produzir a ilusão de movimento a partir de imagens fixas, vistas em rápida sequência, por meio de dispositivo mecânico, óptico, eletrônico etc. 5.1 CINE gênero cinematográfico que consiste na produção de imagens em movimento a partir de desenhos ou quaisquer objetos filmados ou desenhados quadro a quadro.

Nesse sentido, o Teatro de Animação consiste em um tipo de teatro em que os atores são substituídos por objetos, podendo ser, estes, bonecos, máscaras e até mesmo a reprodução da sombra de objetos. Estes, portanto, ganham vida: "O teatro de animação trata do inanimado, por isso também é conhecido como Teatro do Inanimado. Assim, o objeto é o cerne da constituição desse cenário." ${ }^{158}$

Por esse motivo, é possível elaborar uma aproximação entre a teoria do Teatro de Animação e algumas obras de Bojunga, sobretudo quando há, como parte da definição do Teatro do Inanimado, a linguagem e o texto:

O Teatro de Animação constitui um campo, território artístico, gênero ou uma linguagem das artes cênicas que se funda na atuação com objetos, em que o termo atuação não se restringe ao trabalho do ator, congregando outras formas de ações artísticas, como a encenação ou a dramaturgia. Nessa perspectiva, descortinam-se explorações teóricas e práticas em que atuante e objeto adquirem múltiplos estatutos, seja no texto, seja na cena. ${ }^{159}$

Considerando que, em algumas obras bojunguianas, existem personagens-objeto e que o texto da autora é baseado na teatralidade, podem-se analisar as obras que apresentam esse tipo de personagens a partir das características do Teatro do Inanimado. Para facilitar a análise, inicial e brevemente, serão pensadas nos tipos de Teatro de Animação:

\footnotetext{
158 AMARAL, Ana Maria de. Teatro de animação: da teoria à prática. São Caetano do Sul: Ateliê, 1997, p.21.

${ }^{159}$ COSTA, Felisberto. A poética de ser e não ser: procedimentos dramatúrgicos do teatro de animação. São Paulo: Edusp, 2000, p.11.
} 
Há dois tipos de teatro da Animação. O primeiro é aquele em que o objeto aparece em cena como ele mesmo, tentando imitar a realidade, porém sem muito êxito, pois as suas características de objeto são mais sobrepujantes que as humanas, o que leva ao riso. Já no segundo ocorre o oposto do primeiro: os traços humanos sobrepõem-se aos de objeto, o que permite a este estranheza e, ao mesmo tempo, mistério. ${ }^{160}$

Acerca do primeiro tipo, pode-se pensar em obras como A bolsa amarela - em que o objeto que dá nome à obra só é personificado por meio das falas da protagonista -; $O$ sofá estampado - em que o sofá delimita um espaço que ao mesmo tempo é real e fantástico - e $A$ cama, em que a personagem que dá título ao romance é um objeto sem características humanas, apesar de ser humanizado pelas personagens ao longo da narrativa. Esta última obra será analisada como exemplo de primeiro tipo de objeto do Teatro de Animação. Como as características próprias desse objeto distinguem-se das de uma cama comum - já que a Cama personagem é gigantesca e muito antiga -, em alguns momentos há elementos de comicidade, pois o objeto não se adapta a alguns lugares por onde passa, e, também, há traços de lirismo e mesmo de drama, quando as demais personagens atribuem ao objeto um valor sentimental tal qual o que teriam por um ser humano. A seguir, serão analisados esses elementos:

\section{Lirismo}

A Cama desse romance é o objeto central, a partir do qual várias narrativas desenvolvem-se. Uma delas é a de Maria Rita, que é tia de Tobias, a personagem principal. Ela ficou com a Cama que tem sido passada de geração a geração pela família de Tobias; todavia, por Maria Rita estar passando por problemas financeiros graves, decide vender a Cama. Por esse motivo, Zecão, pai de Tobias, resolve subir o morro para chegar até a favela em que a irmã mora para impedi-la de vender a Cama. Porém, no caminho, ele se machuca, mas pede para que o filho continue a viagem e impeça a tia de desapontar a promessa familiar: manter a Cama na família.

Nesse contexto, Tobias chega e entra no barraco da tia:

\footnotetext{
a impotência da cama deixava Tobias abismado. Os pés elaborados. Os veios da madeira. Os entalhes na cabeceira e nas trevas laterais. Só de olhar, Tobias sentia o peso da cama. Foi chegando pra perto: que nenê tão pequeno! Parecia até recémnascido ali na cama.

O colchão era velho, manchado, furado.
}

${ }^{160}$ AMARAL, Ana Maria de. Teatro de animação: da teoria à prática. São Caetano do Sul: Ateliê, 1997, p.22 e 23. 
Só tinha uma coberta pequena no meio da cama. A criancinha estava deitada nela. Mesmo contrastando tanto com tudo em volta, a cama parecia à vontade. E a sensação de estranheza que ela produzia era justo por isso. Sendo tão velha, de certa maneira ela casava bem com o nenê. $\mathrm{O}$ ar barroco e altaneiro que ela tinha se diluía num ar acostumado-com-a-vida, de tanto que nasceram nela, de tanto que morreram nela, de tanto suspiro e gemido de amor que ela tinha ouvido. 161

O olhar aguçado de Tobias dentro do barraco mostra, por um lado, a situação de precariedade em que a tia e o primo moram, o que lhe dá a sensação de estranheza ao perceber que, embora a Cama não combine com aquele cenário, ela, de alguma forma, "está à vontade". Essa sensação de estranheza, porém, não é dominante, já que Tobias identifica que essa familiaridade da cama com o espaço ocorre porque ela é um objeto que acalenta a vida e a morte das pessoas. Assim sendo, o trecho citado parte de um contexto extremamente realista - a descrição do objeto - para um que é bastante lírico - a relação estabelecida entre o objeto e o ciclo da vida: nascimento, vida e morte.

\section{Realismo e drama}

No entanto, o lirismo também não é dominante. Na sequência, a tia de Tobias aparece, o garoto tenta impedi-la de vender a Cama, dizendo que, se ela fizesse isso, ela sofreria uma maldição familiar, da bisavó. Nesse momento, a narrativa ganha traços de dramaticidade, pois o discurso de Maria Rita torna-se agressivo e completamente realista:

- Que bisavó porra nenhuma! O que me importa a maldição dela, do Zecão, da puta que o pariu, se já faz tempo que eu tô vivendo a pior maldição que existe! puxou o seio da boca da criança. - Essa, olha, essa - a criança gritou chorando FOME! Olha pra ele! Tá com fome! Eu também tô com fome! Já olhou pro que tá na tua volta? Já olhou bem pra tudo? Já viu bem o que é ser pobre, viu? Isso sim é maldição. Só mesmo quem não conhece a cara dela é que pensa que assusta a gente com castigo pior que a fome. Volta e conta pro teu pai que eu duvido, mas que eu duvido muito mesmo que uma outra mulher tivesse passado o arroxo que eu venho passado sem até hoje ter vendido uma coisa valiosa feito essa cama. - Bateu outra vez na testa. - Tava aqui, sempre aqui, a promessa que eu fiz. Volta e conta pra ele (se é que ele'inda quer saber) que eu cheguei no fim da linha, tô doente, sem poder trabalhar. Conta que o cara que eu amei sugou meu corpo e minha alma e me largou na pior. Conta que nem leite sai do meu peito; quem podia dar, já deu; quem podia emprestar, emprestou; quem podia ajudar, ajudou; agora tudo que é porta fechou. Vai e diz pra ele que esse troço de inferno, de maldição e família já não me mete mais medo: pra mim só tem um medo: ficar com mais fome. ${ }^{162}$

\footnotetext{
${ }^{161}$ NUNES, Lygia Bojunga. A cama. Rio de Janeiro: Agir, 2002, p.42.

${ }^{162}$ Ibid., p. 44.
} 
É possível notar que a fala da personagem só é interrompida por breves indicações narrativas sobre a movimentação das personagens, tais quais rubricas em textos de teatro. Todo o discurso dramático em torno do assunto a Cama coloca o objeto como cerne da narrativa, sem caracterizá-lo como ser humano, ou seja, ele é tratado como simples objeto, que, como tal, pode ser vendido para garantir a sobrevivência humana. Nesse sentido, portanto, os valores familiares resumidos nesse objeto tornam-se banais diante da necessidade de combater a fome.

\section{Comicidade}

A Cama foi comprada por Elvira, mãe de Rosa, que é recém-casada com Jerônimos. Elvira deu a Cama de presente para a filha; no entanto, o casal morava em um estúdio muito pequeno, de modo que, para caber o móvel no espaço, foi necessária uma mudança grande. A Cama, novamente, foi o cerne das discussões:

Jerônimos perguntou:

- O que é isso?

A pergunta saiu tão aterrorizada, que a Rosa nem entendeu:

- Isso o quê?

- Isso aí.

- A cama?

- Veio de onde?

- Pois essa é a cama que a mãe deu de presente pra gente.

- Não acredito.

- Mas eu não te disse no telefone que ela tinha nos dado uma cama...

- Não contou que ela era assim!

-...e que era uma peça antiga e rara...

- Rara, sim! Peça do Museu de Horrores. Na certa o Drácula dormiu nela. Ou então o Frankenstein.

- O quê?!

- Rosa, que cama sinistra!

- Sinistra o que, meu querido! É uma peça linda, toda trabalhada, jacarandá do mais puro. E olha só pra isso. - Levantou o colchão. - O estrado é todo de palhinha e, repara, está perfeito.

A cara do Jerônimos era só terror.

- Olha pro pé dela. Pé, não, pata! E de um monstro antediluviano.

- Já começa você com seus exageros. Eu concordo com você: a cama é um pouco pesada, mas...

- Um pouco?!

-.mas é uma peça antiquíssima, tem uns duzentos anos, e, olha, fora uma lasquinha aqui, um arranhão ali, ela tá perfeita.

- E o tamanho!

- Cama de casal, não é, Jerônimos?

- Só se for de hipopótamos!

- Ah, para com isso, tá?

- E as garras?!

- Onde é que tem garra? 
- Nessa cabeceira, olha. Então isso não é garra? Pronta pra avançar no primeiro inocente que deitar a cabeça aí. ${ }^{163}$

O diálogo do casal constrói-se de maneira cômica, pois Rosa caracteriza a cama como um objeto ao passo que Jerônimos insiste em vê-la animalizada, com patas e garras. Nesse trecho, percebe-se que o objeto só é animado a partir da fala da personagem, uma vez que, ao longo de toda a narrativa, o objeto não é autônomo.

Já o segundo tipo de objeto do Teatro de Animação tem parte de suas características apagadas, para que se sobreponha a elas a caracterização humana. Este é o tipo mais comum na literatura bojunguiana e, por isso, será feita a análise - iniciando-se com os objetos d'A bolsa amarela e, posteriormente, passando por outras obras que incluem bonecos e máscaras.

\subsubsection{Objetos d'A bolsa amarela}

Na obra bojunguiana, é maior o número de personagens animais que o de objetos; entretanto, em um de seus livros mais conhecidos, traduzidos e ganhador de prêmios internacionais (A bolsa amarela), nota-se uma série de objetos que são personificados. Entre eles está o fecho da Bolsa, que é comprado por Raquel. Outra personagem-objeto é o Alfinete da Fralda, que, ao ser encontrado pela protagonista, pede que ela o leve com ela, pois está cansado de viver jogado na rua. Raquel o guarda no bolso menor da bolsa. Além disso, há o capítulo em que a personagem, o Terrível, tem seu pensamento costurado. Nesse contexto, há a loja de linhas onde estão os carretéis que conversam entre si: um de linha de pesca e o outro de linha forte. Também há a Guarda- Chuva, que mora na Bolsa Amarela de Raquel, e só fala na língua de guarda-chuva, sempre traduzida pelo Galo, que é outra personagem que também mora na Bolsa.

Todas essas personagens-objeto estão relacionadas, pois compartilham o mesmo espaço de morada: a Bolsa Amarela de Raquel. Nesse sentido, embora aparente que nenhuma delas tenha relação uma com a outra, principalmente quando a protagonista-narradora passa a contar a história de cada uma dessas personagens, é a personagem Bolsa Amarela que une todos os fios narrativos, concentrando-se na narrativa central, que é a forma como Raquel lida com as suas vontades: guardando-as na Bolsa Amarela, como forma de reprimi-las. Por essa

\footnotetext{
${ }^{163}$ NUNES, Lygia Bojunga. A cama. Rio de Janeiro: Agir, 2002, p. $71-73$.
} 
razão, é possível afirmar que a Bolsa Amarela é uma personagem-síntese, o que garante visualidade à cena narrada:

O personagem síntese é um recurso abundante na dramaturgia para o teatro de animação. (...) Como signo-visual, o tipo permite que a sua entrada em cena seja precedida por um reconhecimento imediato, uma vez que possibilita a síntese dos caracteres do personagem. ${ }^{164}$

É bastante explícito, na obra, que a Bolsa Amarela tem como função guardar as vontades de Raquel:

\begin{abstract}
Cheguei em casa e arrumei tudo que eu queria na bolsa amarela. Peguei os nomes que eu vinha juntando e botei no bolso sanfona. O bolso comprido eu deixei vazio, esperando uma coisa bem magra pra esconder lá dentro. No bolso bebê eu guardei um alfinete de fralda que eu tinha achado na rua, e no bolso botão escondi uns retratos do quintal da minha casa, uns desenhos que eu tinha feito e umas coisas que eu andava pensando. Abri um zipe; escondi fundo minha vontade de crescer; fechei. Abri outro zipe; escondi mais fundo minha vontade de escrever; fechei. No outro bolso de botão espremi a vontade de ter nascido garoto (ela andava muito grande, foi um custo pro botão fechar).

Pronto! A arrumação tinha ficado legal. Minhas vontades tavam presas na bolsa amarela, ninguém mais ia ver a cara delas. ${ }^{165}$
\end{abstract}

Desse modo, a Bolsa Amarela é uma síntese da própria personagem Raquel, de tudo aquilo que ela gostaria de ser, mas que, por pressão social, passa a acreditar que não é possível. A bolsa é uma síntese, porque, quando Raquel está em conflito - por querer muito ser escritora ou menino, mas, ao mesmo tempo, ter de esconder essas vontades - , a bolsa torna-se extremamente pesada. Já, ao final da obra, graças aos conflitos terem-se amenizado, a bolsa fica leve. Logo, o uso do objeto bolsa para centralizar tantos outros objetos e vontades é uma técnica literária para tratar um assunto delicado da infância: a construção da identidade. A protagonista está em constante conflito entre ser o que ela quer e a pressão de ser o que dizem que ela deve ser. Colocar esse impasse dentro de uma bolsa, ainda de cor amarela, que é uma cor muito alegre, viva e ao mesmo tempo uma cor com significado simbólico ligado ao medo, e agregar a isso recursos teatrais fortifica a expressão artística do tema tratado.

Ademais, a obra também se relaciona ao Teatro de Animação, uma vez que é característica desse tipo de teatro a materialização da metáfora:

Materialização ou Realização da Metáfora

Trata-se de um artifício literário universalmente utilizado no teatro popular que encontra um campo fértil no teatro de animação. Neste, as metáforas e os jogos de

\footnotetext{
${ }^{164}$ BELTRANE, Valmor, org. Teatro de sombras: técnica e linguagem. Florianópolis: Departamento de Artes Cênicas/UDESC, 2005, p.57.

${ }^{165}$ BOJUNGA, Lygia. A bolsa amarela. Rio de Janeiro: Casa Lygia Bojunga, 2013, p. 30 e 31.
} 
palavras ganham corporeidade imagética por meio do objeto, quando, de modo geral, geram imagens poéticas ou cômico-satíricas. ${ }^{166}$

A obra como um todo trabalha várias metáforas relacionadas aos objetos, o que ajuda na construção imagética das cenas. No penúltimo capítulo do romance, por exemplo, há um jogo de palavras cantado pelo Galo Afonso, quando ele diz à Raquel que achou a ideia dele:

Achei, tá achado,

Não vou mais desachar.

Achei, tá achado,

Agora é começar. ${ }^{167}$

O jogo de palavras relaciona-se com a ideia de "início", fato que prevê o que ocorre no último capítulo: a liberdade alcançada pelas personagens e a consequente mudança na vida delas.

Raquel questiona o Galo sobre qual ideia era essa, Afonso responde:

“- Vou sair pelo mundo lutando pra não deixarem costurar o pensamento de ninguém.” 168

Nesse contexto, a frase "costurar o pensamento" pode ser lida como uma forma de manipulação ou mesmo de censura, o que é oposto da liberdade. Apesar desse desejo, Afonso afirma que o mundo era grande e não ia conseguir; assim Raquel lhe dá uma ideia: voar alto para conseguir ir em todos os lugares do mundo. Afonso rebate: não acredita que conseguiria, pois tinha medo de voar. Nesse interim, a Guarda-Chuva, apaixonada por Afonso, disse-lhe que iria junto. Por isso, tiveram a ideia de levá-la para ser consertada, para que pudesse sair pelo mundo com Afonso. Raquel, então, a leva à Casa dos Consertos, lugar onde as mulheres gostam de terem o gênero que têm, o que leva a protagonista a passar a pensar que não seria tão negativo ter nascido menina. A partir dessa série de acontecimentos, que se origina com o Galo e é reforçada com o objeto, Guarda-Chuva, há a ideia da luta por liberdade, que se estende ao pensamento de Raquel, por ela, de certa forma, também ter sido consertada, tal como a Guarda-Chuva, já que apenas a sua presença na Casa de Consertos foi o suficiente para ela passar a questionar, por exemplo, a sua vontade de ser menino. No final desse capítulo, a história da Guarda-Chuva é contada até o fim e o nome dela é revelado: Nakatar Companhia Limitada. O nome faz parte da identidade do objeto, mas os demais personagens

\footnotetext{
${ }^{166}$ BELTRANE, Valmor, org. Teatro de sombras: técnica e linguagem. Florianópolis: Departamento de Artes Cênicas/UDESC, 2005, p. 39.

${ }^{167}$ BOJUNGA, Lygia. A bolsa amarela. Rio de Janeiro: Casa Lygia Bojunga, 2013, p. 104.

168 Ibid., p. 105.
} 
preferem continuar chamando-a de Guarda-Chuva. A imagem deste objeto precisa ser conservada para se entender a metáfora do final do capítulo.

No último capítulo, tanto a personagem-objeto Guarda-Chuva quanto os objetos pipas corporificam a ideia de liberdade, imprimindo, verbalmente, a imagem de um sentimento que fora almejado pelas personagens. Isso pode ser notado, pois Raquel afirma que as vontades passaram a emagrecer, tanto que ela pensou que acabariam sumindo um dia. Nesse contexto, a protagonista tem um sonho em que ela solta pipas em uma praia e, por isso, decide ir com Afonso para a praia, nome do capítulo final. No litoral, Raquel soltou pipa, que era uma atividade considerada apenas masculina; Afonso e Guarda-Chuva estavam juntos, literalmente, pois, quando Afonso quisesse voar alto, a Guarda-Chuva serviria de paraquedas para ele não ter medo de cair e, portanto, continuar voando. Ademais, ao construir as pipas, Raquel tira da bolsa duas de suas três vontades que escondia nela. Transforma essas vontades em pipa. Nesse contexto, há a libertação de Raquel, pois coloca em liberdade as vontades que há tempos vivia escondendo e o faz por meio de uma atividade que, socialmente, é vista como brincadeira de meninos: soltar pipas. A metáfora do voo - o galo que voa alto com a GuardaChuva e as pipas de Raquel - remete à liberdade de ambas as personagens. Ademais, essa cena simboliza a aceitação da identidade da protagonista: menina e criança.

É importante ressaltar que, assim como no restante da obra, as personagens-objeto têm grande significação e ajudam a construir metáforas que reforçam o conteúdo trabalhado na obra. As pipas, embora não personificadas, ganham rabiolas que eram os problemas identitários, tanto que a única vontade escondida de Raquel, assumida por ela, é a de escritora, que não se transforma em rabo de pipa, já que faz parte da identidade da garota ao longo da obra, uma vez que ela cria diversas narrativas. Já o medo do Galo de voar é combatido com o auxílio da Guarda-Chuva, que tem como "sobrenome" "Companhia Limitada". O sobrenome é sugestivo, porque a Guarda-Chuva seria a companhia de Afonso, uma companhia especial por fazer o acompanhamento que ela faz, por isso seria ela especial, limitada apenas a Afonso. Com essa ajuda, o Galo conseguirá voar pelo mundo impedindo que costurem o pensamento das pessoas. Por fim, a bolsa amarela torna-se muito leve, porque até os papéis com os nomes de menino que a Raquel gostaria de ter são dados para os peixes no mar, que não tinham nome, o que fez Raquel gostar de ter o nome que ela tem. Em síntese, é perceptível que a escolha da autora por objetos como personagens ou mesmo como objetos simbólicos, em momentos importantes da narrativa, pode ser um recurso literário que se baseia muito no Teatro de Animação. 


\subsubsection{Bonecos}

A bolsa amarela é a terceira obra de Bojunga, todavia não a único que trabalha com a personificação de objetos. Intramuros, lançada em 2016, apresenta a personagem Nicolina como uma autêntica bonequeira, já que constrói bonecos desde a infância. Um deles, Nicolau, é, por um tempo, parte da narrativa. Embora o romance não seja uma peça teatral, é uma das obras de Lygia Bojunga em que mais é explicitado o uso da técnica do teatro para a composição literária. Antes de analisar o papel dos bonecos nessa obra, serão abordadas algumas definições:

A palavra "boneco", de acordo com o Dicionário Houaiss da Língua Portuguesa, significa:

1. figura similar à boneca ('representação'), reproduzindo indivíduo do sexo masculino. 2.desenho, estampa ou gravura representando homens ou animais.3. p.ext. fig. indivíduo facilmente manipulado e influenciado por outrem; fantoche. 4.fig. $B$ homem fisicamente atraente.

Percebe-se que, na maior parte das acepções da palavra, há a referência à "representação" humana. Assim sendo, no Teatro de Bonecos, estes assumem a representatividade das personagens no lugar do ator. Segundo Amaral ${ }^{169}$, é o que Frank Proschan nomeia de "performing object"170: "são imagens concretas do homem, do animal ou de espíritos criados, apresentados ou manipulados em narrativas ou espetáculos dramáticos'. ${ }^{171}$

Nesse contexto, estabelecendo uma relação entre esse tipo de teatro e a literatura bojunguiana, mais especificamente, com a obra Intramuros, é possível afirmar que os bonecos que aparecem na narrativa não substituem os seres humanos, mas se referem a eles, por meio de uma relação metafórica, relação esta que será explicitada na sequência. Para isso, é fundamental saber que no Teatro de Bonecos há dois tipos destes:

1. O que busca copiar o realismo, seja através da imagem, do movimento ou da voz, a assim substituir o homem pelo boneco, resultando daí figuras grotescas, caricatas, cômicas;

\footnotetext{
${ }^{169}$ AMARAL, Ana Maria de. Teatro de animação: da teoria à prática. São Caetano do Sul: Ateliê, 1997.

170 Nota da autora: "performing objects" não são objetos cênicos nem objetos animados, seu significado é mais abrangente. Inclui figuras antropomórficas e zoomórficas, objetos, imagens, apresentados no Teatro de Animação e/ou Teatro de Formas Animadas.

${ }^{171}$ FRANK, Porchan.The Semiotic Study of Puppets, Masks and Performing Objects. Semiótica, vol. 47, 1983.
} 
2. O que não busca formas realistas e, ao enfatizar o aspecto material da forma, mais se aproxima da essência daquilo que pretende representar, pois quanto menos peculiar, mais abrangente, despertando maior curiosidade.

No primeiro caso, busca-se criar fielmente a realidade e a consequência é uma grotesca caricatura.

No segundo caso, como não se pretende copiar totalmente a realidade e o que se coloca em cena é um não-real (ou real abstratamente interpretado), cria-se imediatamente um impacto e tem-se a impressão de se ter um ser vivo no palco. ${ }^{172}$

Os bonecos que aparecem em Intramuros caracterizam-se como o segundo caso descrito. Em primeiro lugar, há a referência, na obra, a bonecas e bonecos, presentes que Nicolina ganhou de amigos e parentes. Todos são retratados como objetos, guardando suas características de brinquedos. Em segundo lugar, há a menção, no romance, dos bonecos construídos pela protagonista. Estes guardam aspectos rústicos, devido aos materiais que a bonequeira-mirim utiliza para dar-lhes existência. Dessa maneira, percebe-se, claramente, em uma primeira leitura, que os bonecos não representam seres humanos. Todavia, ao se fazer uma leitura mais atenta e investigativa, nota-se que, de alguma forma, todos esses bonecos têm alguma ligação com seres humanos, pois são eles, os bonecos, a significação para a dificuldade com o contato com o mundo externo e a alteridade da protagonista. Essas diferentes significações serão abordadas a seguir.

\subsubsection{Dificuldade com o mundo externo}

É interessante ressaltar que, na obra bojunguiana, apesar de a autora escrever diversas vezes por meio da perspectiva de suas personagens, que, em grande parte, são crianças, nunca houve uma narrativa em que estas estivessem ligadas a um objeto, como uma boneca ou uma chupeta. Estudos de psicanálise, como $O$ brincar e a realidade, de Donald Winnicott ${ }^{173}$, mostram que crianças que se apegam a objetos conseguem lidar mais facilmente com a realidade e passam a ter menor dependência da figura materna, uma vez que, na fase inicial da vida, as crianças não conseguem se distinguir da mãe, acreditam que são uma extensão dela. Mas, ao se apegar, a criança compreende que existe um mundo externo a ela, do qual a mãe faz parte. Em outras palavras, a criança, por meio do objeto, não só consegue lidar melhor com esse mundo que lhe é externo, como também passa a constituir sua identidade. Nesse sentido, nenhuma das crianças retratadas por Bojunga apresenta uma total facilidade de lidar

\footnotetext{
${ }^{172}$ AMARAL, Ana Maria de. Teatro de animação: da teoria à prática. São Caetano do Sul: Ateliê, 1997, p.30.

${ }^{173}$ WINNICOTT, Donald. O brincar e a realidade. Rio de Janeiro: Imago, 1975.
} 
com o mundo externo, pois não têm esse objeto, chamado pela psicanálise de objeto transicional.

No entanto, em sua última obra publicada, Intramuros, surge a presença de bonecos que são construídos pela protagonista: Nicolina. A personagem, quando criança, ganha várias bonecas, porém não gosta de brincar com elas:

\begin{abstract}
Você não faz ideia da quantidade de bonecos que eu ganhei. Quer dizer, da quantidade de bonecas. Boneco eu custei pra ganhar. Mas, desde a primeira boneca que eu ganhei - linda!-, acontecia sempre a mesma coisa: eu tirava ela da caixa, examinava muito bem examinada, sentava ela num canto, e lá ela ficava de perna e braço aberto, feito pedindo pra ser agarrada e brincada. Nunca brinquei nem agarrei boneca nenhuma. Nem pra tirar a poeira de cima delas. E, conforme eu ia ganhando mais bonecas, eu ia fazendo a mesma coisa: sentava elas no chão de bracinho e perninhas abertos, e lá ficavam.

Quando ganhei o primeiro boneco, examinei com atenção redobrada e achei um horror-perfeito, porque, além dele ser, também, todo prontinho, todo bemvestidinho, todo programadinho, aperta daqui, faz xixi, aperta de lá, chora um pouco, quando tirei a roupa dele para examinar ele todinho ainda sofri a frustração de não encontrar, nem vestígio!, da parte principalíssima que eu não encontrava em mim e que eu tinha visto um colega de escola mostrar. Enfiei logo as calças no boneco e lá ficou ele enfileirado no chão $(. . .)^{174}$
\end{abstract}

A personagem não gosta de ganhar bonecas, porém, ao ser presenteada com bonecos, a curiosidade sobre a diferença física, sexual, entre meninos e meninas, é o fator que move o interesse de Nicolina, que logo se frustra, ao perceber que os bonecos, fisicamente, são como as bonecas, pois há a ausência do pênis.

A protagonista afirma, na obra, que é provável que, devido a essa frustração, tenha começado a fazer bonecos aos 9 anos, momento em que ganhou uma penteadeira que tinha um espelho. Nesse período, ela começou a se enxergar e a fazer caretas nele. A figura do espelho em que a criança passa a se enxergar não é exclusiva dessa obra da autora. Em Seis vezes Lucas, que posteriormente será analisado também, haverá essa referência. Esta é essencial para compreender o processo identitário da criança, principalmente de uma perspectiva lacaniana, em que se considerar que crianças entre 6 e 18 meses têm o potencial de criar um imaginário sobre a imagem do que seria a totalidade do eu a partir da sua própria imagem refletida no espelho.

Nesse contexto psicanalítico, aplicado a Intramuros, é perceptível que a época em que Nicolina decide começar a construir bonecos relaciona-se, primeiramente, à fase em que a personagem se vê no espelho. Em segundo lugar, relaciona-se à fase em que ela não aceita a

${ }^{174}$ BOJUNGA, Lygia. Intramuros. Rio de Janeiro: Casa Lygia Bojunga, 2016, p. 26 e 27. 
ausência do órgão sexual masculino em seus bonecos, o que corresponde, também, à parte do processo identitário de gênero a partir da definição, aceitação e reprodução da diferença física entre masculino e feminino.

Dessa forma, as duas primeiras situações que circundam o início do interesse pela confecção de bonecos relacionam-se à esfera privada: a intimidade da personagem diante do espelho, a relação com seus bonecos e a maneira como a personagem constrói a diferença entre masculino e feminino. Nesse sentido, há a dificuldade de a protagonista lidar com o mundo externo, pois existe a não aceitação, consciente ou inconsciente, da diferença de gênero.

Em terceiro lugar, o momento em que a protagonista da obra passa a construir bonecos foi a época em que a mãe dela foi informada por um médico que a filha não era autista. Várias pessoas que conviviam com Nicolina acreditavam na doença da menina, porque ela ria muito em situações inusitadas e, também, porque gostava de ficar sozinha. Ao longo da narrativa, percebe-se que Nicolina tem ataques de riso que são muito estranhos, justamente por estar em situações sociais em que não sabe como lidar com os demais indivíduos. A fim de não ter que passar por essas situações, Nicolina passa a se isolar: inventa doenças e desculpas para não sair de casa, nem mesmo a festas de família. Como não tem contato com os familiares, constrói bonecos que a entendam.

O primeiro boneco que ela fez chamou-se Nicolau. O corpo dele era marcado por um pedaço de cabo de espanador que Nicolina colocou entre as pernas do boneco, dando-lhe possibilidade de ficar maior ou menor, tal como ela tinha ouvido de uns garotos: "pau de verdade aumenta e diminui quando a gente cisma" ${ }^{175}$. Nesse sentido, a protagonista consegue, finalmente, fazer um boneco que representasse um homem. Não só isso, tem também a intenção de criar uma família para o boneco e, posteriormente, quando adulta, a de construir uma cidade inteira para eles: forma de ter companhia, companhia esta que não a faria passar por situações em que o riso tomasse conta dela.

\subsubsection{Alteridade}

\footnotetext{
${ }^{175}$ BOJUNGA, Lygia. Intramuros. Rio de Janeiro: Casa Lygia Bojunga, 2016, p. 30.
} 
Em Intramuros, os bonecos são extremamente importantes para se entender a maneira pela qual Nicolina lida com os outros e como essa forma está relacionada à sua identidade. A protagonista não percebe, ou não quer perceber, que estar somente com os bonecos é uma forma de solidão:

Eu tinha, sem nem ter percebido isso antes, que fingir isso e aquilo, que mentir que isso ou aquilo tava acontecendo... E sabe pra quê? Pra poder ficar sozinha. Quer dizer, sozinha eu não ficava: eu ficava com os meus bonecos. ${ }^{176}$

A partir do momento em que a protagonista se isola do mundo - seja porque não vai à escola para ficar construindo bonecos, seja porque não frequenta lugares onde estejam os familiares, incluindo os próprios pais -, a relação de formação de identidade a partir do contato com o outro torna-se comprometida. O outro com quem ela quer se relacionar é um outro que se pareça com ela e que a compreenda, diferentemente do pai, por exemplo:

Nem liguei do meu pai chamar o Nicolau de monstrinho. Eu estava tão contente de
ter feito ele e de saber que agora, além de mobília verde-musgo, eu tinha com quem
conversar, com quem brincar, que já no dia seguinte comecei a juntar tudo o que
jogavam fora e eu achava que podia servir pra fazer outros bonecos (...).
(...) Eu conversava com todos. Agora pra conversar mesmo, bem fundo, eu
conversava era com o Nicolau. Mesmo porque ele era o que mais cismava e, a toda
hora, ele cismava com uma coisa diferente que eu tinha que fazer. ${ }^{177}$

Os bonecos, portanto, não apenas passam a ser o outro com quem Nicolina acaba convivendo - o que prejudica o processo de identidade por meio da alteridade -, mas também se torna um alter-ego da protagonista. Um exemplo disso é uma cena de um dia em que Nicolau cismou que queria brigar com um gigante, o que levou Nicolina a construí-lo. Nesse mesmo dia, a mãe dela perdeu a paciência, dizendo que ela iria obedecê-la:

Quis me arrastar pelo braço. Eu virei estátua. Aí, ela me pegou pelos cabelos e começou a me arrastar. Ela era mulher forte. Eu era pequena. Fui sendo arrastada até a porta. E foi já saindo do meu quarto verde que, de repente, esta minha mão aqui aproveitou o momento em que minha mãe tava curvada fazendo mais força pra me puxar e baixou o martelão com toda a força na cabeça dela. ${ }^{178}$

Percebe-se, nesse momento, que o desejo do boneco Nicolau se confunde com o desejo de Nicolina: lutar com alguém maior ou mais forte que ele. A "luta" acaba sendo contra a mãe, de quem a menina tanto se queixa, por ela ser, como a autora do livro: mandona, tanto é que chama a mãe e a autora de Coronela. Apesar disso, Nicolina tem que lidar com a angústia da culpa, pois, após o ocorrido com a mãe, esta teve sequelas e, por isso,

\footnotetext{
${ }^{176}$ BOJUNGA, Lygia. Intramuros. Rio de Janeiro: Casa Lygia Bojunga, 2016, p. 19.

${ }^{177}$ Ibid., p. 32 e 33.

${ }^{178}$ Ibid., p. 35.
} 
nunca mais foi a mesma. Como a protagonista lida com a culpa do que fez contra a própria mãe, não se pode afirmar que ela apresenta traços de psicopatia ou mesmo de loucura.

Logo no início da obra, Nicolina afirma que não gosta de ser caracterizada como bonequeira:

(...) eu achei tão ridícula essa coisa de dizer que eu sou bonequeira. Que besteira, não é? Eu sou que nem todo mundo: uma porção! Mas quando a gente diz, eu sou isso, eu sou aquilo, fica parecendo que a gente é só isso ou aquilo, em vez de isso e aquilo e mais um monte de aquilos, é ou não é? ${ }^{179}$

Essa característica a angustia porque ela é o principal fator para compreender o título da obra e a relação dela com outros traços identitários que perpassam pela relação com o outro: a Nicolina modelo - a relação dela com a dona da agência de modelos -; a Nicolina namorada/esposa - a relação dela com Vinícius, o ex-marido -; Nicolina mãe - a relação dela com a filha Nina.

\title{
6.1.3. Máscara
}

A palavra "máscara” apresenta inúmeras acepções no Dicionário Houaiss:

\begin{abstract}
1.peça com que se cobre parcial ou totalmente o rosto para ocultar a própria identidade. 2. teat peça desse tipo com que os atores cobrem o rosto para caracterizar o personagem (p.ex., em gêneros teatrais da Antiguidade greco-romana). 3.p.met. teat cada um dos dois símbolos (o da tragédia e o da comédia) originários do antigo teatro grego. 4. teat expressão que o ator imprime ao rosto em suas caracterizações. "5. fig. cara, semblante, fisionomia 6. fig. falsa aparência. 7. fig. vaidade, autoconfiança pretensiosa. 8. simulacro de rosto (ger. grotesco), como o que se veste no carnaval. 9.área da cara de um animal (p.ex., em torno dos olhos) que se distingue por ser de cor mais escura. 10. representação plástica do rosto ou cópia deste obtida por molde. 11. peça de proteção ao rosto (máscara de soldador, de apicultor, de guerra, de esgrima etc.), ou às vias respiratórias e aos olhos (máscara de mergulho, contra gases etc.). 12. peça de pano com que médicos, dentistas, enfermeiros etc. cobrem a boca e o nariz, para prevenir contágios e infecções. 13. dispositivo ou aparelho com que se cobre a boca e o nariz para facilitar a inalação (p.ex., para ministrar anestésicos e oxigênio a pacientes).14. fig. recurso us. para ocultar ou disfarçar algo.15. med curativo em forma de atadura que é aplicado ao rosto.
\end{abstract}

Nesse contexto, nota-se que o termo "máscara" têm acepções ligadas a disfarces e à criação de identidades ou mesmo à proteção da face. Partindo disso, no teatro, a máscara está relacionada a uma função de observação e de liberação das identidades:

${ }^{179}$ BOJUNGA, Lygia. Intramuros. Rio de Janeiro: Casa Lygia Bojunga, 2016, p. 20. 
Além das motivações antropológicas do emprego da máscara (imitação dos elementos, crença numa transubstanciação), a máscara é usada no teatro em função de várias considerações, principalmente para observar os outros estando o próprio observador ao abrigo dos olhares. A festa mascarada libera as identidades e as proibições de classe ou de sexo. Escondendo-se o rosto, renuncia-se voluntariamente à expressão psicológica, a qual em geral fornece a maior massa de informações, muitas vezes bastante precisas, ao espectador. $\mathrm{O}$ ator é obrigado a compensar esta perda de sentido e esta falta de identificação por um dispêndio corporal considerável. ${ }^{180}$

Dessa maneira, pode-se perceber que a máscara é um objeto bastante usual no teatro, por este ter de apresentar personagens com identidades próprias e, também, por serem observados.

Na literatura de Lygia Bojunga, também é recorrente o uso de máscaras relacionado às temáticas trabalhadas por ela em suas obras, como será abordado a seguir.

\section{*Seis vezes Lucas}

A obra tem esse título porque é formado por seis capítulos:

LUCAS E A CARA; LUCAS E O CACHORRO; LUCAS E A LENOR; LUCAS E O TERRAÇO; LUCAS E A COISA; LUCAS, E AGORA?

A Cara a que o título do primeiro capítulo se refere é a máscara que Lucas cria com massinha de modelar. Esse capítulo se inicia com Lucas vendo o pai se arrumar diante de um espelho. É um dia chuvoso, os pais irão ao teatro, e Lucas tem medo de ficar sozinho. Tenta persuadir a mãe a ficar com ele, sem êxito. Ao ficar sozinho, Lucas fica diante do espelho tentando ver de que lado mais se parecia com o pai. Em alguns momentos, sente medo da chuva, porém se lembra sempre do pai: "herói é quem conquista os medos que tem". Lembrase também que o pai lhe explicou o que era um conquistador: "É quem conquista, é quem vence (...) Eu venci o medo de lutar pelo que eu quero; eu luto pelo que eu quero, Lucas" 181

Apesar das recomendações do pai, Lucas sentia cada vez mais medo. Então decidiu brincar com massinha de modelar e, a partir da massa vermelha, fez sua máscara. Lucas foi modelando a Cara e logo a colocou no próprio rosto, de modo a não se sentir mais sozinho, porque, no espelho, passou a conversar com ela:

\footnotetext{
${ }^{180}$ PAVIS, Patrice. Dicionário de teatro. São Paulo: Perspectiva, 2015, p. 234.

${ }^{181}$ NUNES, Lygia Bojunga. Seis vezes Lucas. Rio de Janeiro: Agir, 1996, p.19.
} 
O Lucas estava contente de ter uma cara ali no espelho; não se sentiu mais sozinho, deu vontade de conversar com ele, foi logo querendo saber:

- Você é um herói?

A Cara fez que sim.

- Quer dizer que você é um conquistador?

A Cara fez que sim.

O Lucas suspirou fundo. Colou ainda mais bem colada a massa na pele. Tão colada, que parecia que a massa era a pele dele. Puxou o cabelo pra frente, tapando o pedaço onde a massa acabava; e agora, um era tão o outro, que o Lucas marchou decidido pra sala, procurou uma música que ele adorava ('Batuque') e ligou o som. Bem alto. O batuque encheu a casa. ${ }^{182}$

Nota-se que esse é um trecho extremamente visual, já que a interação entre o protagonista e a máscara propicia senso de vivacidade à narrativa. $\mathrm{O}$ processo literário que torna essa visualidade possível é a personificação da máscara a ponto de ela ter um nome próprio, mas não a ponto de conseguir se comunicar além de gestos, que são sugeridos pela repetição do uso da expressão "fez que sim”.

Ademais, máscara deu a Lucas uma identidade que ele gostaria de ter: corajoso e dançarino, para poder enfrentar o pai e dançar com a mãe. Partindo dessa ideia, "Máscara é o que transforma. Se bonecos, imagens e marionetes representam o homem, a máscara é a sua metamorfose". 183

Desse modo, a máscara usada por Lucas significa, no início da narrativa, a transformação pela qual o garoto gostaria de passar. No entanto, essa mudança é desejada com o intuito de que a mãe não tenha mais motivos para deixá-lo sozinho.

\section{*A bolsa amarela}

Nessa obra, a máscara aparece no rosto da personagem Afonso, um galo que Raquel deixa morar em sua bolsa. Esse animal não era um galo comum, pois era o Rei, personagem criada por Raquel, para tentar lidar com a vontade dela de ser escritora. No capítulo três do romance, chamado $O$ galo, Raquel o descreve e, na segunda página do capítulo, ela demonstra surpresa graças à presença da máscara: "Eu estava de boca aberta: nunca tinha visto um galo usando máscara. Ele usava. Preta. Tapando a cara todinha. Só dois furos pros olhos." 184

\footnotetext{
${ }^{182}$ NUNES, Lygia Bojunga. Seis vezes Lucas. Rio de Janeiro: Agir, 1996, p. 22.

${ }^{183}$ ROSENFELD, Anatol. O teatro épico. São Paulo, Perspectiva, 2004, p.63.

${ }^{184}$ BOJUNGA, Lygia. A bolsa amarela. Rio de Janeiro: Casa Lygia Bojunga, 2013, p.33.
} 
Nesse capítulo, o galo dialoga com a protagonista e ele mesmo explica sobre como apareceu na bolsa dela. Ele havia fugido do galinheiro onde tinha de ser autoritário:

$\mathrm{Eu}$ chamei minhas quinze galinhas e pedi, por favor, pra elas me ajudarem. Expliquei que vivia muito cansado de ter que mandar e desmandar nelas todas noite e dia. Mas elas falaram: 'Você é o nosso dono. Você é que resolve tudo pra gente.' Sabe, Raquel, elas não botavam um ovo, não davam uma ciscadinha, não faziam coisa nenhuma sem vir me perguntar: 'Eu posso?' E eu respondia: 'Ora minha filha, o ovo é seu, a vida é sua, resolve como você achar melhor', elas desatavam a chorar, não queriam mais comer, emagreciam, até morriam. Elas achavam que era melhor ter um dono mandando o dia inteiro: faz isso! faz aquilo! bota um ovo! Pega uma minhoca! Do que ter que resolver qualquer coisa. Diziam que pensar dá muito trabalho. ${ }^{185}$

Nesse contexto, Afonso conta para Raquel a confissão que fez para as galinhas:

Quando eu expliquei que desde pequenininho eu sonhava com um galinheiro legal, todo mundo dando opinião, resolvendo as coisas, achando furada essa história de um galo mandar e desmandar a vida toda, sabe o que é que elas fizeram? Chamaram o dono do galinheiro e deram queixa de mim. (...)

'Não quero mandar sozinho! Quero um galinheiro com mais galos! Quero as galinhas mandando junto com os galos!' 186

Como Afonso gostaria de viver em um galinheiro democrático, sem a submissão feminina, ele decide fugir e, por isso, acaba tendo de usar uma máscara, para se esconder. Com esta, ele se torna tão irreconhecível que Raquel só o reconhece quando ele a retira:

- Sabe, você é tão parecido com um galo que eu conheço, mas tão parecido mesmo...

Ele tirou a máscara e olhou pra mim. Parecido coisa nenhuma. Era ele mesmo. O Rei. O galo do romance que eu tinha inventado. ${ }^{187}$

Nesse sentido, a máscara utilizada por essa personagem tem o intuito de ocultar a identidade da personagem, tanto que, quando o Galo a retira, a protagonista o reconhece, cena essa que potencializa a carga teatral do objeto máscara. Partindo-se dessa análise, é possível afirmar que Raquel, ao criar um galo que queria dar empoderamento às fêmeas, está, de alguma forma, já tentando lidar com um dos conflitos identitários pelo qual passa: o desejo de ser menino, por esses terem mais liberdade que as meninas. Porém, da mesma maneira que Raquel precisa esconder as vontades dela na bolsa amarela por medo de ser incompreendida socialmente, o galo precisa se esconder do antigo dono, que o queria reprimindo as galinhas, mesmo contra a vontade de Afonso. Em resumo, tanto Raquel, escritora, do sexo feminino,

\footnotetext{
${ }^{185}$ BOJUNGA, Lygia. A bolsa amarela. Rio de Janeiro: Casa Lygia Bojunga, 2013, p.35.

${ }^{186}$ Ibid., p.36.

${ }^{187}$ Ibid., p.34.
} 
quanto Afonso, sua personagem, do sexo masculino, precisam escamotear quem realmente são.

Mesmo depois de Raquel ter se libertado de duas de suas vontades e de Afonso ter conseguido a companhia da Guarda-chuva para voar mais alto e disseminar suas ideias pelo mundo, ambos ainda guardam seus objetos que são ligados a esse processo identitário: Raquel passa a ter menos peso na bolsa amarela, a qual ainda é utilizada pela menina; Afonso ainda usa a máscara com medo de o seu antigo dono estar dentro de um avião e de reconhecê-lo voando alto pelo céu e de ser levado de volta ao galinheiro. Logo, apesar de as personagens terem resolvido suas pendências identitárias, não conseguem se desfazer completamente desses objetos, o que lhes trazem algum tipo de segurança.

\section{*Querida}

Já na capa, produzida pela editora Casa Lygia Bojunga, há uma máscara branca, que é tradicionalmente usada no teatro:

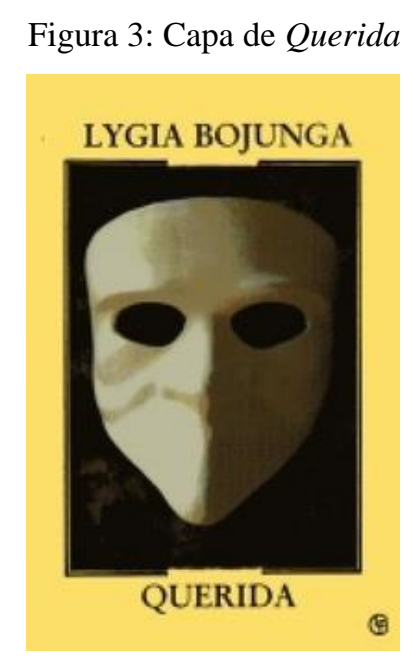

Fonte: Lygia Bojunga (2009)

A referência ao teatro é feita em alguns momentos da obra, principalmente porque existe uma personagem misteriosa, chamada Ella, que foi atriz de teatro e era completamente apaixonada pela profissão. A personagem principal, Pollux, no começo da obra, é um menino que foge de casa porque não aceita o relacionamento da mãe com outro homem. O protagonista sai de casa e vai procurar um tio dele, que, há muito tempo morava isolado da família, desde que a mãe dele, avó de Pollux, faleceu. Ao chegar na casa desse tio, chamado 
Pacífico, o garoto vai descobrindo um pouco da história do tio com a Ella, que pode ser resumida neste trecho, em que o protagonista conta ao tio que a mãe já tinha feito uma comparação entre os dois:

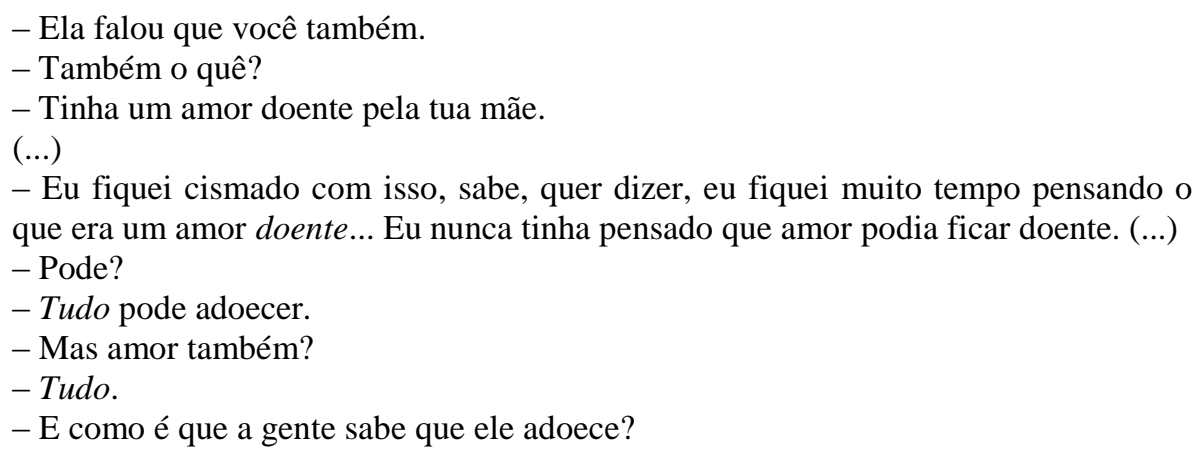

- Ah, Pollux, acho que a gente sabe porque... porque ele carrega a gente. Quer dizer, a gente começa a adoecer junto com ele. Vai perdendo a alegria, vai deixando de se importar com os outros, fica só pensando na doença, acaba até ficando meio cansado de viver, o que, em outras palavras, significa: vontade de morrer. E quando a gene fica desse jeito é porque... tá doente, não é?

- Você ficou assim?

- Durante um tempo, fiquei, sim.

- Por causa da tua mãe, quer dizer, da minha vó?

O Pacífico fez que sim. (...)

- Eu acho que, se você tem amor por ela - fez um gesto de cabeça pro jardim -, isso sim: é um amor doente.

- Por quê?

- Por quê?! Puxa vida, Pacífico, se teu amor por essa mulher não é doente, então eu não entendo mesmo o que é um amor doente. Todo mundo lá em casa fala que você curou do amor que você tinha pela tua mãe quando conheceu essa mulher e que você abandonou tudo por causa dela (...), e que veio se enfiar nesse alto de montanha com ela pra fugir do mundo; quando eu chego aqui você diz que essa casa não é tua, que ela não é tua mulher, diz que cozinha pra ela, que serve ela, mas que não vive com ela, vive pra ela, e essa mulher ora tem cabelo branco, ora parece quase da minha idade, ora tá caindo de velha e dizendo que ela sou eu e que o nome dela é Ciúme. Caramba! E você ainda quer que eu ache que esse amor tá vendendo saúde? ${ }^{188}$

Pode-se perceber que o lugar onde Pacífico encontra-se no início da narrativa é o espaço da recusa do mundo externo - família, amigos, a própria casa, a própria esposa -, recusa essa que ocorre pela não superação total do luto pela mãe. A ausência de um ser feminino, o qual pudesse amar incondicionalmente, sem esperar nada em troca, leva Pacífico ao isolamento e, ao mesmo tempo, a tentar amenizar essa dor dedicando sua vida a outra mulher: Ella. Como é um sentimento fora dos padrões sociais, já que Pacífico é mais um serviçal do que um amante, ele não sobreviveria ao mundo externo, que o criticaria. Por esse motivo, o espaço inicial da narrativa, a casa de Ella, é um lugar misterioso, ela mesma o é. Outra possibilidade, menção claramente feita no trecho do livro transcrito, é a de que a atriz seria a encarnação do Ciúmes, que não permite que Pacífico continue a sua vida, situação essa

${ }^{188}$ BOJUNGA, Lygia. Querida. Rio de Janeiro: Casa Lygia Bojunga, 2009, p. 155-157. 
também vivida por Pollux, uma vez que também procura o isolamento junto ao tio, por esse ter um amor doente, tal qual ele.

Toda essa contextualização é importante, porque Pacífico procura dar uma explicação racional para as aparições de Ella: a profissão de atriz e o gosto por máscaras.

\footnotetext{
Desde pequena a Ella gostou de fazer máscaras. Ninguém faz tão bem quanto ela. Aprendeu uma técnica, que aperfeiçoou na Europa, na feitura de máscaras que aderem ao rosto como uma segunda pele. Com essas máscaras ela faz da cara o que quer: passa da mais linda à mais monstruosa. Às vezes ela finge que o gramado é um palco: escolhe um papel qualquer pra representar e se bota na máscara mais adequada ao papel.

- Ela é maluca?

- Um pouquinho só.... - o Pacífico respondeu, meio brincalhão. E depois, sério: Ela sempre adorou o teatro. E foi uma atriz famosa. Teve que abandonar o palco. Mas não abandonou o gosto de representar. Então... representa pra mim. Ou pras estrelas... Hoje representou pra vocês... ${ }^{189}$
}

A máscara teatral aparece nessa obra como instrumento de mudança e de construção de personagem. Ella, como atriz, pode ser quem quiser e apresentar-se para quem lhe interessar. Embora essa explicação aparente ser racional, o fato de a atriz se apresentar somente para Pacífico e para as estrelas, novamente, a coloca em um contexto de existência dúbio. No entanto, a autora faz uma escolha literária de iniciar esta obra pelo prólogo, como forma de deixar o leitor sob alerta acerca da duração da vida daquela mulher: ela teria falecido depois de Pollux ter se tornado adulto, o que permite o leitor saber que, apesar de Ella ser misteriosa, ela, de fato, estava viva. O prólogo consiste, sobretudo no Teatro Grego, na primeira parte do gênero tragédia em que se expunha o assunto a ser abordado na peça teatral. O prólogo poderia ser feito por meio de um diálogo ou de um monólogo. No caso de Querida, o prólogo é um monólogo que se desencadeia a partir do contato com um obituário de jornal.

Após o prólogo, há um grande capítulo chamado "o primeiro encontro", em que é contada a história dos dois dias em que Pollux foge de casa, por motivos de ciúmes da mãe, e passa-os com Pacífico na casa de Ella. Na sequência, há dois capítulos curtos: $O$ intervalo e $O$ sonho. No primeiro, conta-se a trajetória de Pollux como escritor; já no segundo, um sonho do protagonista com uma dupla extremamente pobre com quem teve contato nos dias em que passou com o tio. Depois disso, o penúltimo capítulo da obra, nomeado de Segundo encontro, conta o reencontro de Pollux e Pacífico após a morte de Ella, pois o jovem escritor foi até o Retiro, sítio onde o tio morava com a Ella. Lá o protagonista relembra as memórias de infância e conhece a casa toda. A casa como um todo era a personificação da arte, uma vez

${ }^{189}$ BOJUNGA, Lygia. Querida. Rio de Janeiro: Casa Lygia Bojunga, 2009, p. 157 e 158. 
que havia um quarto de cinema, um quarto para leitura, um quarto para as vestimentas de teatro e, por fim, um quarto somente onde ficavam as máscaras da atriz, inclusive a máscara com a qual ela interpretou o Ciúmes para Pollux. Nesse momento da narrativa, tem-se plena certeza de que a peça teatral que Pollux assiste quando criança foi direcionada a ele, já que, no momento, ele não queria aceitar o novo casamento da mãe, por ciúmes. Nesse sentido, a máscara foi utilizada como personificação do sentimento, como maneira de o protagonista se dar conta do problema pelo qual estava passando. Como consequência disso, o menino reflete sobre tudo o que está vivendo:

Bem que o Pollux se preparou pra dormir. Mas foi só apagar a luz que a lembrança
de tudo que ele tinha vivido nos últimos dois dias tomou conta dele. Começou a
repassar cada cena na memória. Desde o momento em que viu chegada a hora de
aplicar na Iara o castigo planejado até a conversa que tinha acabado de ter com o
Pacífico. ${ }^{190}$

A reflexão sobre o castigo que estava tentando aplicar na mãe e as conversas com o tio fizeram-no perder o sono e ter cada vez mais medo de ficar sozinho no quarto. Nesse contexto de autoavaliação de suas condutas e de receio da solidão, ele adormece e acorda, pela manhã, decidido a voltar para casa. Toda essa atitude foi despertada pela máscara do Ciúmes, usada por Ella. Por isso, a máscara e o teatro são formas utilizadas nessa obra para despertar o autoconhecimento de Pollux em relação ao ciúme que sentia da mãe.

O sentimento ciúme é um dos fios narrativos desse romance, uma vez que tanto Pollux, quanto Pacífico, sempre tinham esse sentimento em relação às suas respectivas mães. Desse modo, a história do protagonista e a do tio cruzam-se por meio da existência de Ella, que é a responsável pela consciência desse sentimento e pela tomada de decisão sobre o que fazer com ele: no caso de Pacífico, o amor e o ciúme que tinha pela mãe é repassado para Ella; no caso de Pollux, a reflexão o faz não querer a solidão e o isolamento, como fizera a atriz e o tio, até mesmo porque o menino ainda se transformaria em homem e conheceria outra forma de amor feminino, que é, aliás, uma significante parte da conversa entre ele e o tio no segundo encontro que têm. No último encontro com Pollux, Pacífico faz perguntas sobre os relacionamentos amorosos do sobrinho e, em meio a isso, confessa que passou a ter relações sexuais com Ella na noite em que Pollux passou no Retiro. Essa confissão é importante para a compreensão do nome do livro e da capa: Querida é a forma como tanto Pollux quanto Pacífico chamavam as suas respectivas mães; e, após o contato físico carnal com Ella, o tio

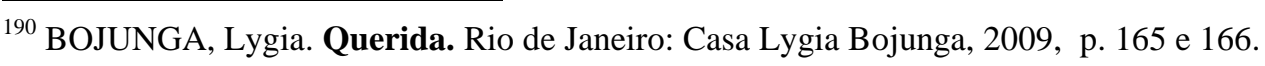


passa a chamá-la de Querida, o que Pollux ainda não conseguira fazer com nenhuma outra mulher, já que nenhum de seus relacionamentos foi intenso o suficiente para isso.

Com relação à mascara, que já é destacada desde a capa da obra, é importante notar que há uma aproximação entre a profissão de Ella - atriz-e a de Pollux - escritor. A máscara para a atriz não só era importante para a construção de seus personagens, como também para ajudar a esconder possíveis deformações que teve ao tentar se suicidar, o que leva à ideia de transformação de identidade, que, por sua vez, era totalmente aceita por Pacífico, já que quis viver no Retiro com ela. O próprio nome da personagem, segundo o dicionário de nomes próprios, significa: “'outra'. É a forma normanda do nome germânico Alia, uma abreviação dos nomes que continham o elemento ali, que quer dizer 'outro'.,"191

É interessante notar que esse nome está contido dentro de vários outros nomes femininos: Isabella, Rafaella, Gabriella, Daniella, entre outros. Mais uma comprovação de que o nome da personagem está totalmente relacionado às máscaras.

Porém, a máscara para Pollux tem outro significado: o escritor, por meio da literatura, transmitiria ao público um conteúdo que é uma preocupação do autor, porém, sem aparentar ser muito explícito: “Afinal de contas, literatura não deixa de ser isso mesmo: um 'anúncio' público, sempre meio disfarçado, que os escritores fazem de suas próprias preocupações e anseios...., não é?" 192

Dessa forma, a literatura seria um tipo de máscara, em que a inquietação do escritor seria transformada, de maneira indireta, disfarçada, em uma obra de arte, com preocupações estéticas, tal como ocorre no teatro, porém, sem se distanciar do conteúdo a ser transmitido. Em várias obras de Bojunga, ela deixa muito explícito que o ato de escrever é um ato de solidão, que requer o isolamento do mundo externo. Com base nisso, pode-se entender o fim do livro, como último capítulo o Pra você que me lê, em que a autora deixa claro que "colocou o ponto final" na história, mas que passou a pensar sobre as personagens. Uma dessas reflexões foi a morte de Pacífico, que teria deixado o Retiro para Pollux com um bilhete em seu testamento:

Da mesma maneira que o Retiro me ajudou a encontrar a paz e a felicidade, espero que também te ajude a escrever os livros que você ambiciona criar.

Boa sorte!

\footnotetext{
${ }^{191}$ Significado do nome Ella. Disponível em: https://www.dicionariodenomesproprios.com.br/busca.php?q=Ella. Acesso em: 12 mai. 2017.

${ }^{192}$ BOJUNGA, Lygia. Querida. Rio de Janeiro: Casa Lygia Bojunga, 2009, p. 122.
} 
Pacífico. $^{193}$

A felicidade de Pacífico foi poder servir a Ella, que conseguiu retomar a alegria de viver isolando-se no Retiro, criando personagens, máscaras para a apresentação teatral de um público de uma pessoa só. Da mesma forma, Pollux, talvez, um dia precisasse desse mesmo isolamento, já que a única mulher com quem ele talvez tivesse um relacionamento mais duradouro - Lorena-, deixou-o, justamente por não aguentar vê-lo sempre escrevendo um novo livro. Nesse sentido, talvez fossem os artistas, seja de teatro ou da literatura, seres incompreendidos por necessitarem de tempo em contato com o isolamento para que possam, por meio da imaginação, de seus processos criativos, encontrarem a máscara - forma - mais adequada para tratar do conteúdo que querem expressar para o mundo externo.

Ademais, considerando que a máscara faz parte do processo de criação identitária, pode-se relacionar esse aspecto do objeto com a origem do nome Pollux. É feita uma referência direta na obra à origem mitológica do nome do protagonista, que teria sido escolhido por seu pai. Segundo a mitologia grega, a mãe de Pollux teria tido dois ovos: em um, os gêmeos Castor e Helena, que são filhos dela com um mortal; em outro, os gêmeos Pollux e Clitemnestra, que são imortais, por serem filhos de Zeus. Pollux e Castor são conhecidos por serem muito amigos e lutarem contra injustiças, tendo o mortal habilidades manuais e o imortal habilidades intelectuais, como a astúcia. Nesse sentido, pode-se fazer uma aproximação entre Pacífico e Pollux, pois aquele vive feliz em servir Ella, realizando atividades braçais; ao passo que o segundo se realiza por meio da atividade braçal e intelectual da escrita. Além disso, Pacífico é mortal; porém, Pollux, por meio de sua literatura, não o será. Essa ideia de legado literário é retomada em Intramuros, como será analisado no último capítulo.

\section{*O abraço}

Assim como em Querida, a capa de $O$ abraço já remete ao universo das máscaras, já que não se consegue identificar o rosto de quem está na capa:

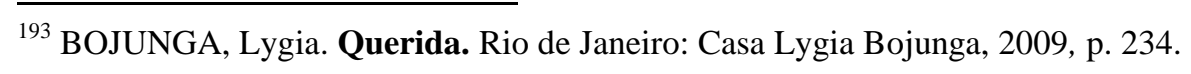


Figura 4 - Capa da obra $O$ abraço

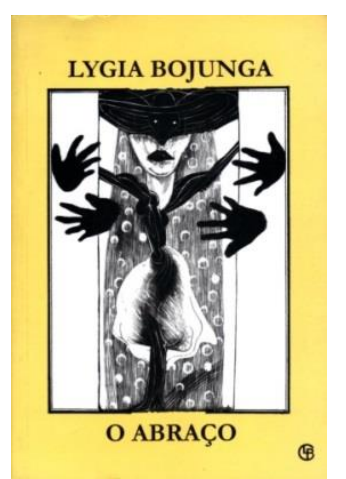

Fonte: Lygia Bojunga, ilustração de Rubem Grilo (2014)

A imagem da capa é sugerida em algumas páginas da obra, como será mencionado posteriormente. Ademais, a máscara é um instrumento importante nessa narrativa literária, uma vez que, a fim de tratar um assunto extremamente delicado e também polêmico - o estupro -, a autora a coloca em uma personagem bastante importante para a história: a Morte. Já nas primeiras páginas, antes do início da narrativa, há a imagem dessa máscara e de várias mãos, imagens essas que representam a morte:

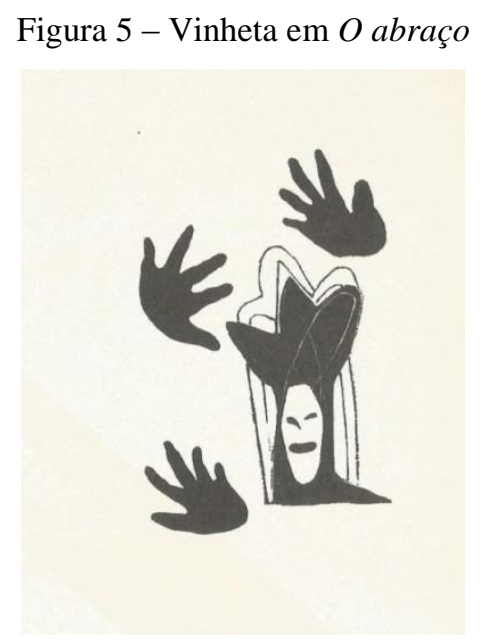

Fonte: Lygia Bojunga, vinheta de Rubem Grilo (2014)

A protagonista, Cristina, no dia de seu aniversário de 19 anos, foi a uma festa a fantasia em que os convidados se fantasiavam de uma personagem de contos brasileiros. Ela se fantasiou de samambaia, personagem do conto $O$ abraço, que também tinha como tema central a morte. Ao fazerem uma peça sobre o conto, não há a presença da personagem Morte, 
o que é motivo de reclamação de uma mulher que estava vestida com uma máscara e que se prontificou a representar o papel.

Após a encenação, Cristina fala com essa mulher misteriosa, que lhe dá um abraço e, por isso, sente que ela era uma das duas Clarices: a amiga de infância ou a menina que aparecia em seus sonhos após Cristina ter sido estuprada. Nessa festa, a mulher não retira a máscara para Cristina saber quem ela é. Nesse sentido, a máscara, nesse primeiro momento da narrativa, tem o intuito duplo de representar a morte e de criar na protagonista a curiosidade a respeito de quem era essa misteriosa mulher: "Ela não conversava com ninguém; escondida naquela máscara, ela deslizava de sala pra sala, numa solidão que só vendo" 194

O mistério, nesse trecho, é criado imageticamente graças à escolha de termos como "escondida" e "deslizava", que remetem a ideias fantasmagóricas. Outrossim, o mistério sobre a mulher era grande porque ela não conhecia ninguém na festa, não tirava a máscara e só conversou minimamente com Cristina. Esse contexto de poucas explicações é importante para criar-se o clima de dúvida acerca de qual Clarice seria a mulher mascarada:

\footnotetext{
Lá pelas tantas eu escuto uma voz perguntando: posso te ajudar? A Mulher estava do meu lado. Disfarçada do mesmo jeito (ah, que vontade de olhar pra cara dela, em vez de olhar pra'quela máscara). Sem perder um minuto, eu respondi: pode! Mas antes me diz uma coisa: você é a Clarice, não é?

Ela ficou um tempo parada, depois fez que sim.

A minha Clarice ou a Clarice dele?

Ela ficou outra vez um tempo quieta antes de responder: - As duas. ${ }^{195}$
}

A máscara, portanto, guarda a identidade das duas Clarices com as quais Cristina teve contato: na vida real e nos sonhos. Sobre esse assunto relacionado ao duplo, haverá uma análise mais aprofundada no subitem acerca do Teatro das Sombras.

Mais para o fim da narrativa, após ter se encontrado com o seu possível estuprador, por quem nutria atração sexual, Cristina é levada a outra festa a fantasia, onde a anfitriã é: "uma figura em preto e branco, mascarada, chapéu de três pontas, véu de renda. Conforme ela abriu a porta, os braços também se abriram feito coisa que ia colher a Cristina num abraço." 196

Após ser recebida, a protagonista volta ao carro que a levou para dizer à outra personagem: “- Eu não precisei falar nada porque ela foi logo dizendo que vai ensaiar comigo

\footnotetext{
${ }^{194}$ BOJUNGA, Lygia. O abraço. 6. ed. Rio de Janeiro: Casa Lygia Bojunga, 2014, p.15.

195 Ibid., p. 44 e 45.

196 Ibid., p. 75.
} 
sem máscara. Parece que ela adivinhou essa aflição que eu estou pra olhar bem pra cara dela.” 197

No decorrer da narrativa, vão sendo criadas expectativas em relação a dois desejos que Cristina quer realizar em um futuro próximo: o de se encontrar pessoalmente com o homem que a estuprou na infância e o de ver Clarice sem a máscara. Na cena em que a protagonista se despedir da personagem que a levou até a festa, há o diálogo entre a imagem que é inserida no texto e a cena que será narrada:

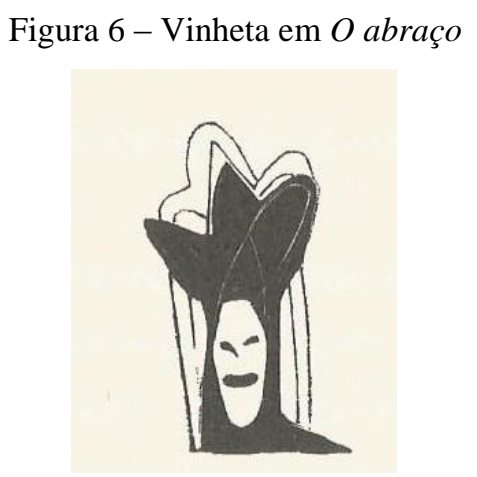

Fonte: Lygia Bojunga, vinheta de Rubem Grilo (2014)

Porém, nesse momento, sem as mãos ao redor dela.

Após a inclusão dessa imagem, é descrito o cenário da festa dentro da casa, por onde Cristina e a Mulher passam até chegar ao jardim. A Mulher tenta contar à protagonista sobre o que será a peça que irão encenar, mas é interrompida:

- Você disse que ia tirar a máscara pra gente ensaiar.

Sem dizer uma palavra, a Mulher chegou bem perto de Cristina e estirou o pescoço. Cristina ficou ainda mais nervosa, por que que era ela que tinha de tirar a máscara? A mulher esperando.

De coração meio disparado, Cristina pegou o gesso branco; puxou a máscara.

A máscara não se mexeu.

Cristina puxou com mais força.

Nada.

- Me ajuda, Clarice.

Mas a mulher também não se mexeu.

- Clarice, eu não tô conseguindo, me ajuda.

A Mulher imóvel.

Mas, de repente, a Mulher avisou:

- Olha ele aí chegando, o outro personagem do nosso conto. ${ }^{198}$

Esse último trecho precede a morte de Cristina, que será, novamente, estuprada. Tudo indica que seja pelo mesmo homem que a estuprou quando criança, uma vez que ela

${ }_{197}^{197}$ BOJUNGA, Lygia. O abraço. 6. ed. Rio de Janeiro: Casa Lygia Bojunga, 2014, p. 46.

${ }^{198}$ Ibid., p. 78 e 79. 
descobriu que este era um palhaço, tal qual o homem que, nessa última festa, a estupraria e a mataria. $\mathrm{O}$ fim da narrativa segue com novo diálogo entre cena e imagem:

Figura 7 - Vinheta de cena final em $O$ abraço

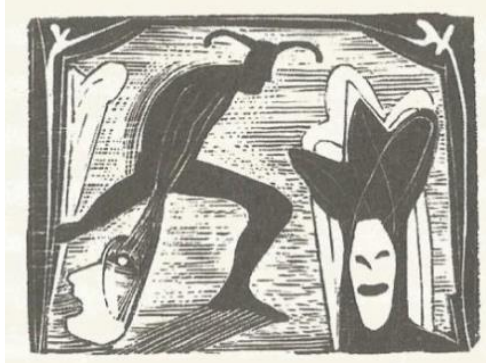

Fonte: Lygia Bojunga, vinheta de Rubem Grilo (2014)

Posteriormente a ela, há uma página inteira, tarjada, marcando o final da narrativa:

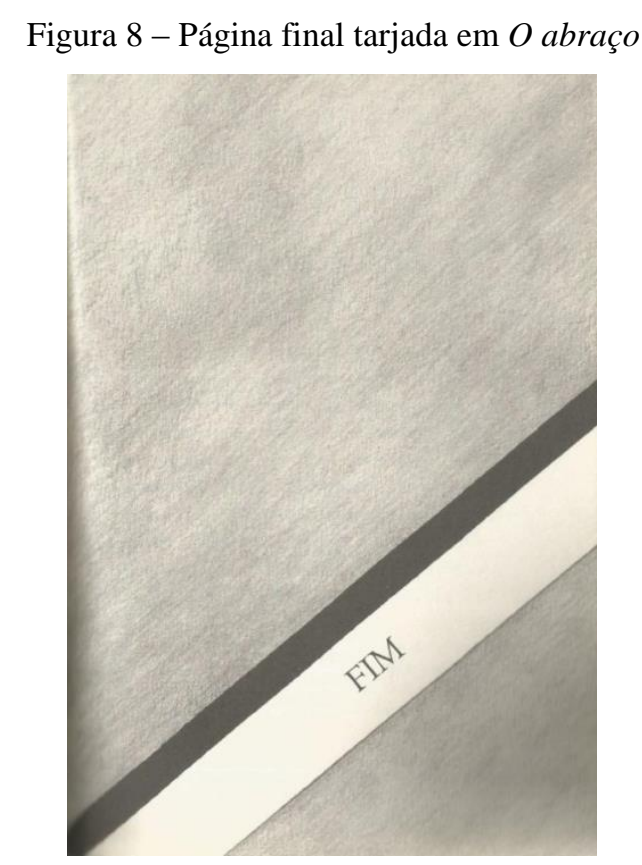

Fonte: Rubem Grilo (vinheta); Lygia Bojunga (projeto gráfico); Paulo César Cabral (programador visual) (2014) 
Percebe-se, no desenho que antecede essa página tarjada, que há a mesma imagem da Morte que aparece em outros momentos do livro: seja pela ilustração ou pela descrição da roupa da personagem misteriosa. Junto a ela, há a imagem de um palhaço - reconhece-se o chapéu, estilo bobo da corte - que está andando e puxando algo: pode ser uma máscara ou uma criança. O objeto ou ser que ele puxa está justamente entre as duas pernas, o que remete ao órgão sexual dele e, também, à imagem do estupro. Nesse contexto, a imagem da máscara é usada como forma de reforçar o assunto abordado. A lembrança do estupro, para a protagonista, não era tão explícita, de modo que ela foi recuperando-a aos poucos, sempre lidando com a Clarice dos seus sonhos, que, supostamente, seria a Clarice que o estuprador havia matado durante o ato de violência sexual. Como essa personagem aparece nos sonhos de Cristina, uma das chaves de interpretação é que seria ela a consciência da protagonista a respeito do quão perigoso seria ter gostado, em partes, da experiência do estupro a ponto de querer encontrar o agressor novamente.

A escolha pelo objeto máscara nessa narrativa foi essencial para que a autora pudesse transgredir os limites entre realismo e sobrenatural. Nesse sentido, a relação entre máscara e teatro é uma técnica muito eficiente para surtir tal efeito: "Se a função do teatro é transformar - ligar uma realidade à outra -a máscara é o instrumento ideal para isso." 199

Nota-se, imageticamente, essa fusão do sobrenatural - a presença misteriosa da morte - com o real - vida de Cristina -, desde o início da narrativa, por meio da iluminura escolhida pela autora para destacar a primeira letra do romance:

Figura 9 - Iluminura em $O$ abraço

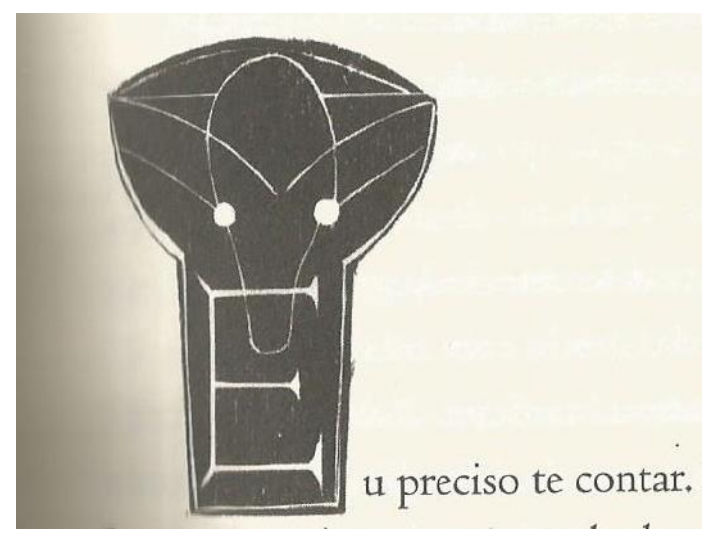

Fonte: Rubem Grilo (2014)

${ }^{199}$ ROSENFELD, Anatol. O teatro épico. São Paulo: Perspectiva, 2004, p.66. 
A letra "E" da palavra "eu", que remete à Cristina, é escrita dentro da imagem de uma máscara, muito parecida com o chapéu que aparece na capa do livro. Considerando que a máscara é um elemento fundamental para descrever o impacto causado pela personagem Morte, é possível afirmar que o começo da narrativa já indica o possível fim da protagonista: ser envolvida pela Morte, na ânsia de descobrir o que há embaixo da máscara da suposta amiga Clarice, a tal ponto que conhece plenamente a morte, ao passar pela sua própria.

Portanto, a literatura bojunguiana, a fim de expressar determinados assuntos sociais, como identidade e morte, utiliza-se da imagem da máscara, instrumento típico da linguagem teatral, sobretudo no Teatro do Inanimado.

\subsection{TEATRO DAS SOMBRAS}

As quatro primeiras acepções da palavra sombra do Dicionário Houaiss são:

1. obscuridade produzida pela interceptação dos raios luminosos por um corpo opaco."este lado da casa estava imerso na s." 2. espaço menos iluminado, sobre o qual não incide luz direta."gostava de cochilar na s. do sótão" 3. ausência de luz; escuridão (tb. us. no pl.). 4. ausência da luz solar; noite, escuridão.

Percebe-se, portanto, que a "sombra" por si só não existe, ela sempre depende do seu oposto para existir, que é a luminosidade.

Nesse sentido, no Teatro das Sombras, há a importância do escuro e de algum elemento que ilumine algum objeto oculto dos olhos do espectador, para que este só veja as sombras propiciadas pelo objeto. Dessa forma, apenas com os contornos da imagem, sem os detalhes dela, é possível transformar a ideia negativa que se tem de sombras em uma técnica para ressignificar objetos e narrativas:

Como a sombra está ligada ao medo, geralmente ganha um cunho negativo. Mas, no teatro das sombras, ela pode ter o papel oposto. Daí a ideia de poesia.

Teatro de sombras surge no Oriente, ligado à religião, à alma "um diálogo entre o consciente e o inconsciente ${ }^{200}$

Percebe-se, com o surgimento do Teatro das Sombras no Oriente, que a dicotomia entre escuro e claro não se refere somente à literalidade desses recursos, mas também são

\footnotetext{
${ }^{200}$ BELTRANE, Valmor. Teatro de sombras: técnica e linguagem. Florianópolis: Departamento de Artes Cênicas/UDESC, 2005, p. 62 e 64.
} 
metáforas: a luz remete àquilo que é conhecido, é, portanto, parte do consciente do indivíduo; já a escuridão relaciona-se ao desconhecido, composta pelo inconsciente das pessoas.

Dessa forma, pode-se afirmar que os seres humanos lidam melhor com aquilo que conhecem, pois lhes permite a sensação de domínio do objeto ou da experiência vivida, sendo, por isso, responsável pelo sentimento de controle do seu destino. Sendo assim, é muito comum nas artes, incluindo o teatro e a literatura, o uso da cor preta ou mesmo de efeitos sombrios para marcar tudo o que está próximo à ordem do desconhecido, do misterioso. Por essa razão, a sombra, na maior parte das vezes está relacionada ao medo, ao pânico e até mesmo à morte. Assim sendo, as sombras podem ter ligação com assombração, que é um "sentimento de terror causado por coisas que não se podem explicar e que frequentemente são interpretadas como sobrenaturais", ou ao assombro, que pode ser um grande espanto ou admiração. Nesse sentido, as sombras podem ser, também, parte de um universo lúdico. Esse fenômeno ocorre quando a escuridão toma vida própria, transformando-se inclusive em personagem, como é o caso da sombra de Peter Pan. Essa imagem teatralizante da sombra aparece na obra Seis vezes Lucas, na capa da edição da Editora Agir:

Figura 10 - Capa de Seis vezes Lucas

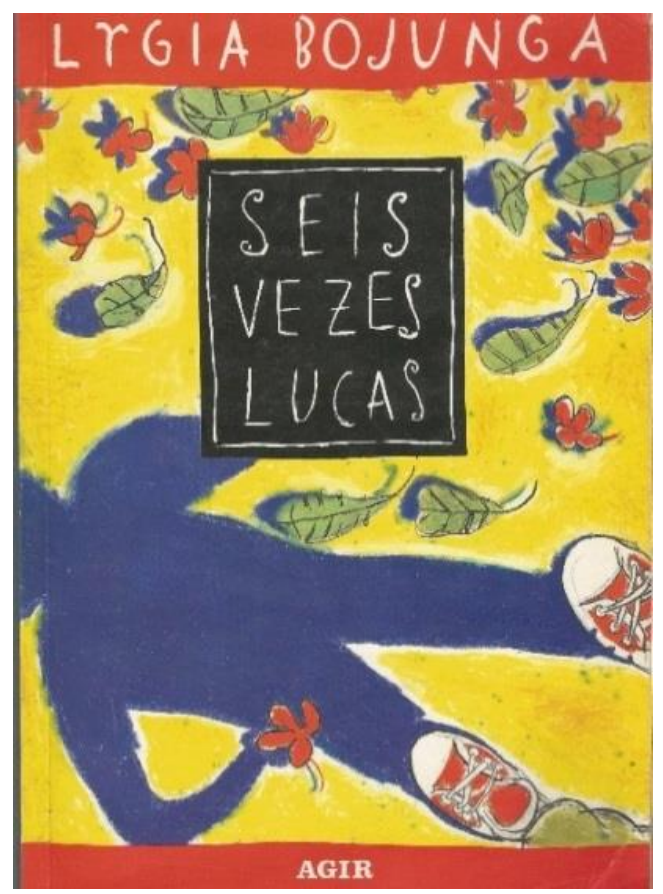

Fonte: Lygia Bojunga, ilustração da capa de Roger Mello, Editora Agir (1996) 
Considerando a vida que as sombras ganham: "Nesse teatro, a sombra tem autonomia, não depende de um corpo ou objeto para existir, pois ela tem vida própria." ${ }^{201}$ Tendo vida própria, por meio das palavras, os traços de escuro ou de claridade podem aparecer no teatro e também em outras artes, como a literatura, de modo a não caracterizar uma cena apenas, mas a dar-lhe mais intensidade.

As sombras também podem estar relacionadas à solidão:

Na sociedade atual, com os meios de comunicação multiplicados as pessoas esttão sempre conectadas umas às outras, sempre rodeadas de gente, e - ao mesmo tempo sentem-se solitárias. A linguagem do teatro de sombras trabalha justamente com a solidão. É uma linguagem 'solitária',202

É o que acontece com as personagens das duas obras bojunguianas analisadas na sequência:

- $\quad O$ abraço - narrativa em que a protagonista, apesar de estar em contato com amigos, com festas, sente-se na solidão de conviver com uma experiência de violência sobre a qual nunca havia falado, somente sonhado. Nessa obra a escuridão transforma-se em morte.

- Nós três - história trágica de um relacionamento que já é anunciado por meio da ausência de vida (sombras, escuridão), que vai se intercalando com momentos felizes e ensolarados, que são os momentos referentes à vida. O relacionamento em questão liberta uma das personagens de sua solidão refletida na obsessão pela arte, mas, ironicamente, é ele também que a faz voltar a ser intimista.

Sabe-se que Lygia Bojunga Nunes escreve romances, todavia, como já foi afirmado inúmeras vezes, há traços de recursos teatrais em suas obras. Não se pretende afirmar que as obras bojunguianas são Teatro de Sombras, mas demonstrar que, assim como no Teatro das Sombras, os recursos da iluminação e da escuridão utilizados na construção da narrativa são essenciais esteticamente para a compreensão do conteúdo das obras mencionadas.

\section{*O abraço}

\footnotetext{
201 BELTRANE, Valmor. Teatro de sombras: técnica e linguagem. Florianópolis: Departamento de Artes Cênicas/UDESC, 2005, p. 62-64.

202 STÜPP, Raquel in: BELTRANE, Valmor (organizador). Teatro de sombras: técnica e linguagem. Florianópolis: Departamento de Artes Cênicas/UDESC, 2005, p. 66.
} 
Como essa obra trata do tema "morte", ao longo de toda a narrativa há o uso ilustrativo da cor preta e também o de recursos literários que tornam a cena ora escura, ora clara. Esse processo é típico do Teatro das Sombras, e é muito aplicado por Lygia Bojunga em algumas de suas obras que trabalham com assuntos dicotômicos, mas que se complementam, tais como, nesse caso, a morte e a vida, que são tratados por meio do realismo e do fantástico.

No trecho abaixo, do Pra você que me lê contido em Nós três, Lygia Bojunga afirma que fez uma escolha estética visual não apenas para reforçar o tema da obra, mas também para vinculá-la a outra obra que tem a mesma temática: $O$ abraço.

Ao planejar o projeto gráfico de Nós três e d'O abraço, quis não só incluir um Pra você que me lê em cada um dos dois livros, como também estabelecer um pequeno vínculo visual - sombrio, naturalmente - pra unir o meu par. A princípio pensei em uma determinada ilustração se repetindo nos dois livros. Depois mudei de ideia: me lembrei que, não faz muito tempo, recebi da Alemanha um envelope com tarja, contendo um cartão também tarjado, que anunciava a morte de um meu editor (SIC). Que espanto! Num pulo, as tarjas me levaram à primeira infância, às muitas vezes que me deparei com a correspondência tarjada que o correio trazia lá pra casa, e que - num tempo em que eu não tinha aprendido a temer a Morte - eu chamava de 'enfeite preto'.

Quando compreendi melhor que o 'enfeite preto' era sinal de luto, e do quanto o luto faz sofrer, eu já morava no Rio, onde as tarjas tinham caído em desuso.

Passei décadas sem receber nem ver uma correspondência tarjada. Que espanto quando chegou o cartão da Alemanha ostentando o 'enfeite preto'.

Ao me lembrar deste fato, resolvi tarjar as páginas que anunciam os capítulos de Nós três e repeti o sinal de luto nas páginas inicial e final da narrativa d'O abraço, estabelecendo, assim, um vínculo discreto pro meu par. ${ }^{203}$

As tarjas pretas já indicavam que o assunto do conteúdo do envelope era a morte de alguém. Da mesma maneira, Bojunga procura anunciar o assunto por meio desse mesmo recurso visual:

Figura 11 - Página introdutória de $O$ abraço

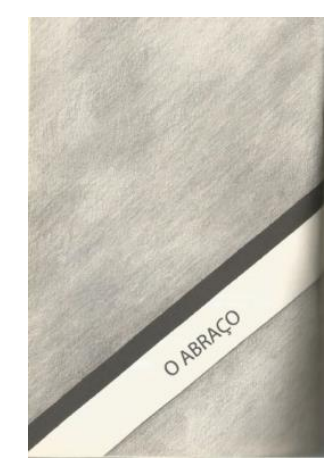

Fonte: Rubem Grilo (vinheta); Lygia Bojunga (projeto gráfico); Paulo César Cabral (programador visual) (2014)

${ }^{203}$ BOJUNGA, Lygia. Nós três. 4ed. Rio de Janeiro: Casa Lygia Bojunga, 2008, p. 138-140. 
Nota-se que as imagens só conseguem ter o preto realçado em contraste com a parte mais clara. Esse mesmo realce é alcançado em uma mudança mínima da capa da obra publicada, primeiramente, pela Editora Agir, e, posteriormente, pela editora Casa Lygia Bojunga. Abaixo, segue a capa do livro publicado pela Agir:

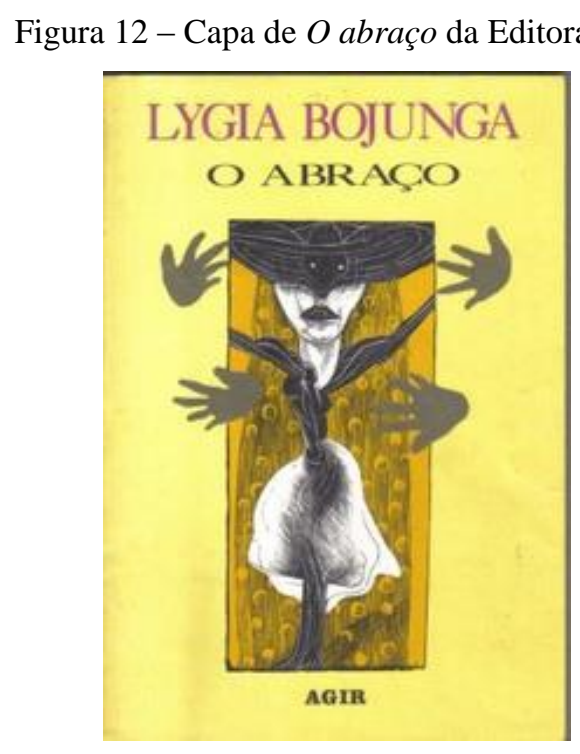

Fonte: Lygia Bojunga, Editora Agir

Percebe-se que o fundo da imagem é preenchido pela cor amarela, ao contrário da ilustração da capa publicada pela Casa Lygia Bojunga, que mantém a imagem, todavia substitui a cor amarelo pela branca, realçando ainda mais o preto, tal qual como ocorre nas outras ilustrações ao longo do texto literário.

Esse mesmo contraste entre preto e branco é admirado pela protagonista ao perceber como essas cores da vestimenta da Mulher misteriosa proporcionaram maior verossimilhança à personagem Morte:

- Eu fiquei toda arrepiada com a cena que você fez.

- Por quê?

- Não sei. Quer dizer, eu acho que foi porque... você representou tão bem... e ficou tão forte ver a Morte assim...

- Assim?

- Feito você está vestida e mascarada. A primeira vez que eu vi esse disfarce (foi um quadro italiano que eu vi numa exposição), eu fiquei fascinada, sabe.

- ?

- Essa vestimenta, esse contraste assim tão forte do preto e do branco me fascina mesmo. $^{204}$

${ }^{204}$ BOJUNGA, Lygia. O abraço. 6 ed. 3. imp. Rio de Janeiro: Casa Lygia Bojunga, 2014, p. 15 e 16. 
Segundo o Dicionário de Símbolos ${ }^{205}$, a cor branca: "simboliza tanto ausência de cor como a soma das cores, por isso, ele pode constar nas duas extremidades do círculo cromático, como numa alusão ao início e ao fim. Assim, algumas culturas o usam no luto, porque a morte precede a vida eterna."

Assim sendo, o branco da máscara da Morte pode enfatizar a ideia de fim da vida ou, simplesmente, como está contido na fala da personagem, é o contraste com a cor preto, que, no Ocidente, geralmente, é a cor que representa o luto, sendo o branco nesse caso, portanto, a simbologia da vida.

A referência às duas cores aparece também na descrição física do estuprador:

eu tive a impressão de que ele era um homem feito de água.

O Homem da Água estava me olhando com força. Podia ter uns trinta anos. A cara era muito atraente (será que foi por isso que, no princípio, eu não me assustei?)", (...)

Ele estava vestido do jeito que milhões de homens se vestem, mas, naquele lugar, era um jeito tão estranho! Terno azul-marinho, camisa de colarinho e gravata cinzenta, imagina, e tudo bem velho e surrado, o terno, a camisa, a gravata. O cabelo era preto e um pouco encaracolado.

A cara era muito branca, e uma barba-uma-porção-de-dias-sem-fazer. ${ }^{206}$

O que aparece na descrição como atraente é o rosto, justamente este que era muito branco e bonito, fatos que levariam Cristina a não ter medo do homem, inicialmente. $\mathrm{O}$ rosto dele contrasta com o restante da roupa, que é, além de escura, antiga.

Essa ambiguidade de, ao mesmo tempo, gostar e não gostar do Homem da Água no tempo passado, de quando ainda não sabia quem era esse Homem, é claramente exposta na narrativa de Cristina depois de adulta. A partir disso, percebe-se que, embora seja adulta e já saiba a gravidade da violência que sofreu, a protagonista guarda uma lembrança não só positiva do rio - sua primeira experiência sexual, embora violenta -, mas também a classifica como a melhor descoberta que ela teve:

Era tanta coisa pra descobrir na fazenda que eu nem me importei mais de ser só eu criança no meio da gente grande.

De tudo que eu ia descobrindo e gostando, o que eu gostei mais de descobrir foi o rio $^{207}$

\footnotetext{
${ }^{205}$ Dicionário de símbolos online. [homepage]. Disponível em: https://www.dicionariodesimbolos.com.br. Acesso em: 07 abr.2017.

${ }^{206}$ BOJUNGA, Lygia. O abraço. 6 ed. 3. imp. Rio de Janeiro: Casa Lygia Bojunga, 2014, p.25.

${ }^{207}$ Ibid., p. 23.
} 
Abaixo, seguem alguns trechos do romance em que a imagem do preto e do branco remetem à imagem dicotômica entre morte e vida e há a construção delas de maneira vívida, levando o leitor a imaginar o jogo de dependência entre claro e escuro:

\title{
Trecho I:
}

"A gente entrou mais fundo na mata. O sol sumiu. Me deu medo. Quis me fincar no chão. Ele me arrastou."208

Nesse trecho, já se percebe que, quando a protagonista segue o seu algoz, perdendo-se em um espaço que não era de conhecimento dela (a mata), o responsável pela iluminação, pela vida - o sol -, desaparece, resultando no sentimento de medo.

\section{Trecho II:}

\begin{abstract}
A porta se abriu, jogando um pouco de claro lá dentro. No chão tinha uma esteira, tinha uma roupa espalhada, penca de banana madura, uma garrafa de água, e tinha também uma bolsa de plástico, aberta (era pão que tinha lá dentro?), mas não vi mais nada: o Homem tinha me puxado e fechado a porta.

Senti a mão dele soltando meu braço.

Agora eu só via o escuro. ${ }^{209}$
\end{abstract}

Nessa passagem, nota-se o jogo do claro com o escuro, sendo este referente à porta fechada, à não escapatória da protagonista. Nesse ambiente, o desconhecimento é tanto que Cristina, vendo-se imersa ao escuro, mesmo com o homem soltando o braço dela, ultrapassa o limite do medo e sente-se em pânico. Em "agora eu só via o escuro", pode-se imaginar, literalmente, a ausência de iluminação, mas também é possível verificar que, nos momentos de escuridão, a morte faz-se presente ao longo da obra. Essa relação entre morte e escuro pode ser percebida na própria fala do estuprador sobre o abraço dele:

Trecho III:

Eu me lembro também do barulho de uma chuvarada caindo. E foi com essa chuva chovendo lá fora que a voz dele falou assim, eu te prometo, Clarice, eu te prometo que desta vez você não vai morrer no meu abraço. E me abraçou mais forte que das outras vezes e entrou mais forte dentro de mim.

E no escuro que ia sempre continuando e continuando aconteceu aquele momento incrível: eu acordei e a porta estava aberta! Fiquei olhando pro claro lá fora. Um claro cada vez mais claro. ${ }^{210}$

\footnotetext{
${ }^{208}$ BOJUNGA, Lygia. O abraço. 6 ed. 3. imp. Rio de Janeiro: Casa Lygia Bojunga, 2014, p. 27.

${ }^{209}$ Ibid., p. 30.

${ }^{210}$ Ibid., p.33.
} 
A imagem do abraço aparece como a imagem da morte: no abraço do estuprador, as vítimas falecem, por não aguentarem o ato de violência, como é sugerido lexicalmente pela autora em "no escuro que ia sempre continuando e continuando", em que se liga o escuro da cena com o escuro relacionado ao ato sexual, sugerido pela repetição do verbo 'continuar' no gerúndio. Possivelmente, Cristina desmaia e só acorda com o claro que vem de fora do espaço da violência. O claro, portanto, está relacionado à vida, ao fato de a protagonista ter sobrevivido às sombras daquela violência.

Trecho IV:

(...) Consegui pedir pra ele acender a luz.

- Aqui não tem luz, Clarice, isso aqui é um barraco muito ruim. (...)

- Eu não sou Clarice, eu sou Cristina, eu me chamo Cristina.

- Clarice - ele repetiu.

- Cristina!

Ele riu, pedi pra ele abrir a janela.

- Aqui não tem janela.

- Abre a porta então.

- Depois.

- Tá escuro! - Eu não sabia se era cheiro de pão que eu estava sentindo. Mas tinha cheiro de terra, isso eu sabia. Eu estava sem sapato e o meu pé sentia a umidade do chão de terra. -Tá escuro! - eu disse de novo, e fui dizendo mais alto, tá escuro, tá escuro. A mão dele tapou minha boca; a voz veio chegando pra perto do meu ouvido; fechei o olho com força feito coisa que, não vendo o escuro, não ia mais ter escuro nenhum. ${ }^{211}$

É interessante notar, nessa passagem, que é na ausência da luminosidade que se pode criar o que se bem entender, inclusive como faz Cristina, que imagina que o escuro não existe e que, portanto, não há motivo para medo: “A sombra não existe em si, ela é apenas uma projeção, um reflexo, e é justamente a sua imaterialidade que permite ao imaginário criar o que bem entender." 212

Antes de o estupro consumar-se, ainda há o jogo de alternância entre claro e escuro: a criança quer a luz, repudia o escuro, a violência daquela situação, Cristina quer a luz da porta, ou da janela, que metaforicamente, remetem à passagem de um espaço para o outro. Já o algoz quer mantê-la no escuro; todavia, chama-a de Clarice, que, ironicamente, é um nome próprio que significa "aquela que esclarece, que ilumina". A personagem Clarice, que havia sido amiga de Cristina na infância, também foi estuprada por esse criminoso; porém, não resistiu e faleceu. Além disso, para enfatizar a escuridão da cena, a autora lança mão de

\footnotetext{
211 BOJUNGA, Lygia. O abraço. 6 ed. 3. imp. Rio de Janeiro: Casa Lygia Bojunga, 2014, p. 31.

212 BELTRANE, Valmor. Teatro de sombras: técnica e linguagem. Florianópolis: Departamento de Artes Cênicas/UDESC, 2005, p. 62.
} 
recursos narrativos que permitem intensificar os outros sentidos da vítima, por esta estar no escuro, tal como o tato e o olfato.

A cena final - em que, assim como no início da narrativa, a protagonista vai a uma festa onde estará a mulher misteriosa - é a que, literariamente, reúne todas as estratégias anteriores ligadas ao contraste do claro e do escuro: intensificação dos outros sentidos, sobretudo o do olfato; a narração do ato do estupro; a imagem da morte, que permeia toda a narrativa por meio da presença da cor preta.

Cristina foi levada a essa festa por uma companhia que só a deixa na festa, mas que se preocupa com o fato de haver pouca luz, para um lugar onde ocorrerá um evento. A protagonista não desconfia de nada, sai do carro e entra na casa, onde é recebida pela mulher misteriosa, que a leva da casa para um jardim:

“O jardim se estendia ainda um bom pedaço antes de acabar na mata. Cristina respirou mais fundo o ar da noite:

- Aqui tem cheiro de terra, não é? E barulhinho de grilo também, imagina. Ih, mas que samambaias tão lindas!

(...)

Cristina vai se deixando puxar lá pro fundo do jardim. Mas, de repente, se lembra da

Mulher. Empaca; olha pra trás; não vê ninguém. Grita, Clarice! Mas a mão do Homem tapa o grito depressa.

Chega na cabeça de Cristina a lembrança forte do rio passando, do cheiro de pão, de chuva batendo no teto de sapê. (...)

O jardim já vai se desmanchando na escuridão (...)

Derruba ela no chão. Monta nela. O escuro toma conta de tudo. ${ }^{213}$

Nesses acontecimentos finais da obra, há uma convergência de todos os recursos utilizados antes para potencializar a cena final: a morte de Cristina por meio d' $O$ abraço.

Nota-se que ela está indo para além do jardim, que acabava em uma mata, tal como a mata em que ela foi estuprada pela primeira vez. O último e fatal estupro ocorreu à noite, ao passo que, o primeiro se passou parcialmente sob a luz do sol, que, posteriormente, some. Ambas as referências remontam à escuridão, ou seja, ao prenúncio da morte. O olfato e a audição dela se aguçam, por notar o cheiro de terra e os sons dos grilos, bem como todo o cenário da mata onde fora violentada na infância. Essa parte da narrativa torna explícita a ligação com a cena da violência sofrida na infância. Nesse sentido, caracteriza a reviravolta da narrativa:

${ }^{213}$ BOJUNGA, Lygia O abraço. 6 ed. 3. imp. Rio de Janeiro: Casa Lygia Bojunga, 2014, p. 78-81. 
O cheiro pode ser, e frequentemente é, um recurso utilizado para caracterização de personagens, cenários, atmosfera ou ainda um recurso para definir mudanças dramáticas na história. É um artifício sutil, mas bastante significativo na criação dos principais elementos de uma narrativa. A presença de um cheiro específico ou a ausência dele pode determinar a existência, a identidade e o caráter de uma personagem. ${ }^{214}$

Além de o cheiro caracterizar o espaço da mata, caracteriza também a personagem que, ao longo da narrativa, tem a curiosidade de se encontrar com o seu algoz, o que pode ter relação com um traço identitário da protagonista referente a traços da Síndrome de Estocolmo. Essa síndrome é um estado psicológico de uma vítima que acaba tendo afeto pelo seu algoz. Esse sentimento pelo agressor, no caso de Cristina, é anunciado pela própria protagonista ao afirmar, antes de contar a violência pela qual passou, que aquele período fora de casa foi um período de descobertas.

Novamente, na cena final, Cristina é estuprada, mas também é assassinada. Após o término da narrativa, há a ilustração já mostrada. Essa imagem também concatena todas as ilustrações da obra que estão relacionadas à morte: o palhaço - que será analisado na seção dedicada ao Teatro Circense -, o ato de arrastar a vítima e a máscara da personagem misteriosa.

Vale ressaltar que, em meio à escuridão que vai se alastrando na cena, a personagem, que supostamente, era a amiga Clarice, desaparece. Junto a isso, há a figura do palhaço. Personagens que surgem e desaparecem sem nenhum tipo de explicação, o que dá à narrativa um final de cunho fantástico.

Desse modo, percebe-se a total relação entre a morte e a cor preto. De acordo com o Dicionário de Símbolos:

\begin{abstract}
A morte representa a finalização de um ciclo e muitas vezes a sua simbologia está associada a elementos negativos, como a escuridão, a noite. A morte é uma destruidora da existência (desmaterialização), de um determinado tipo de existência, e carrega o do mistério de nos transportar para mundos desconhecidos, para o inferno (sombrio), para o céu (paraíso), ou outros locais designados por diferentes crenças e mitologias.

Associada ao elemento terra, a morte pode não ser um fim em si, pode ser uma transformação, uma revelação do desconhecido, a introdução ou o início de um novo ciclo, por isso, simboliza também a regeneração e a renovação. ${ }^{215}$
\end{abstract}

214 GOMES, Cristina.O cheiro das palavras: o olfato na narrativa literária.2009. 118 f. Dissertação (Mestrado em Letras) - Pontifícia Universidade Católica do Rio Grande do Sul, p. 24.

215 Dicionário de símbolos online. Disponível em: https://www.dicionariodesimbolos.com.br/morte/ Acesso em: 05.mai.2019 
Contrariamente a essa visão obscura da morte, há a personagem Clarice, amiga de Cristina, que aparece em seus sonhos, é representante do branco, da luz, do oposto da morte, já que o nome significa "a que é brilhante", "luminosa" ou "ilustre". O uso desse significado aparece na narrativa de maneira indireta, quando, por exemplo, a protagonista conta que: "Desde a primeira vez que ele me chamou de Clarice, a lembrança da minha Clarice se acendeu..." 216

Clarice é uma menina que foi estuprada e morta supostamente pelo mesmo agressor da protagonista. Cristina sonha com Clarice, sonhos esses que demonstram sempre tipos de abraço que levam à morte, sendo, por isso, o próprio abraço uma metáfora para o estupro e para a morte, embora seja, ao mesmo tempo, um contato físico que remete ao carinho. Os abraços que Clarice dá na amiga em sonho são, dessa forma, uma espécie de aviso sobre o que futuramente irá ocorrer: o encontro de Cristina com o seu possível agressor e a sua atração sexual por ele. Há dois sonhos que chocam bastante a protagonista. Um deles é o que Clarice afirma ter morrido:

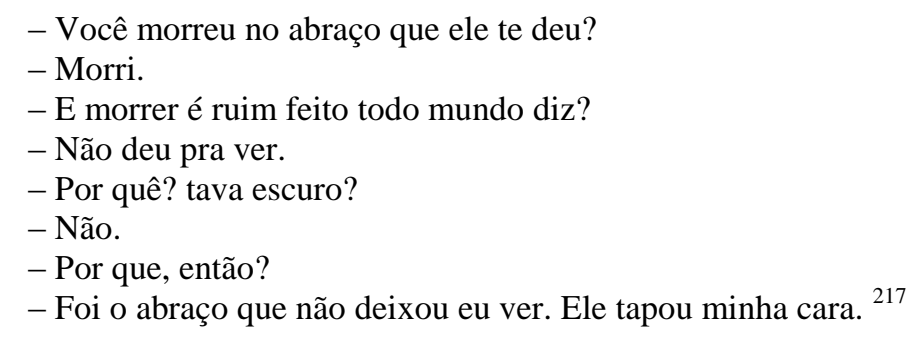

O outro é o que a amiga aparece já como adulta.

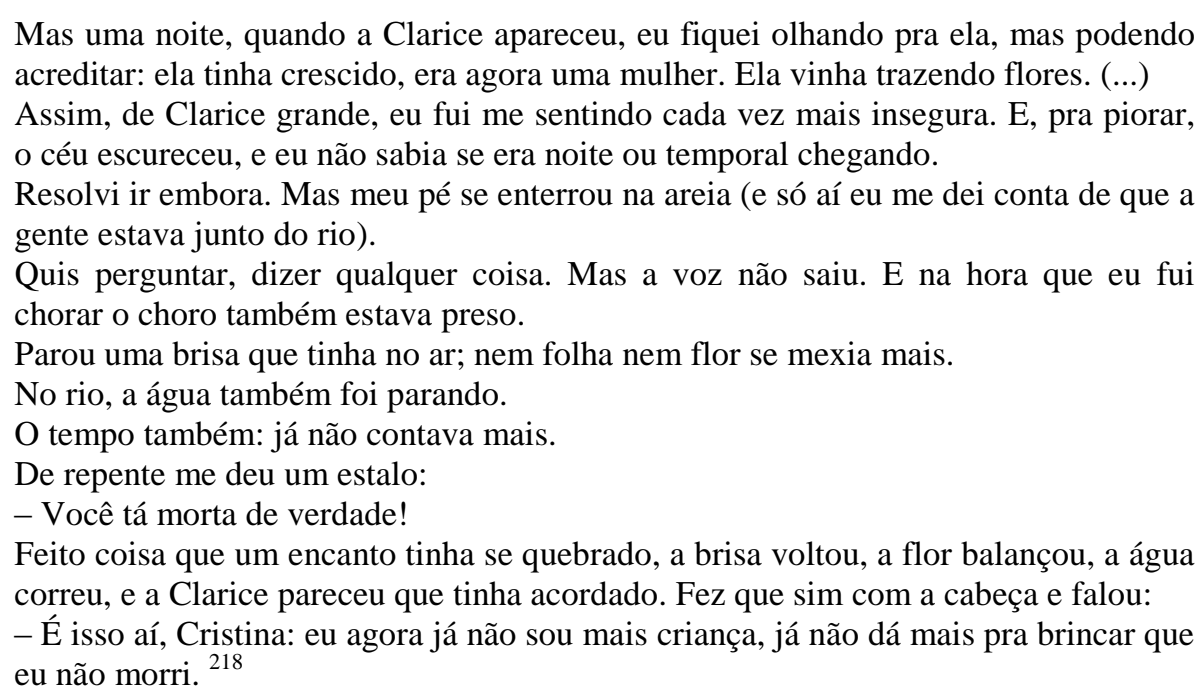

\footnotetext{
${ }^{216}$ BOJUNGA, Lygia. O abraço. 6. ed. Rio de Janeiro: Casa Lygia Bojunga, 2014, p. 31.

${ }^{217}$ Ibid., p. 39.
} 
Esse sonho é extremamente interessante para a compreensão das metáforas ligadas à morte: junto ao céu que se escureceu, todos os elementos da natureza foram parando: a brisa, a folha, a flor, a água. Só por meio da escuridão aliada à paralisia de tudo é que Cristina percebeu, de fato, que a amiga estava morta. Apesar de morta, queria deixar um abraço com Cristina:

- É esse o abraço que eu deixo pra ti, Cristina. Pra você nunca esquecer, pra você nunca perdoar o que te aconteceu aqui neste rio. - Foi indo pra trás, sumindo no escuro, dizendo de novo e de novo, é pra você não esquecer, é pra você não perdoar, é pra você nunca perdoar. ${ }^{219}$

Dessa maneira, os traços do Teatro das Sombras, que une a escuridão e a claridade para projetar imagens totalmente centrais nas narrativas são recursos utilizados em $O$ abraço, por a obra, como um todo, precisar, a todo momento, desse traço estético para dar mais intensidade a uma experiência tão violenta, que é o estupro seguido de morte.

\section{*Nós três}

Obra publicada em 1987, oito anos após $O$ abraço. Também é tarjado nas separações em capítulos. São estes: A flor azul; O tempo passando e eles conversando; Outra vez a Flor Azul; $O$ epílogo. Como já mencionado, o uso das tarjas pretas é feito para antecipar a presença da morte na obra. Na sequência, seguem as páginas tarjadas com os nomes dos capítulos:

\footnotetext{
${ }^{218}$ BOJUNGA, Lygia. O abraço. 6. ed. Rio de Janeiro: Casa Lygia Bojunga, 2014, p. 40 e 41.

${ }^{219}$ Ibid., p. 43.
} 
Figura 13 - Página tarjada do capítulo A flor azul

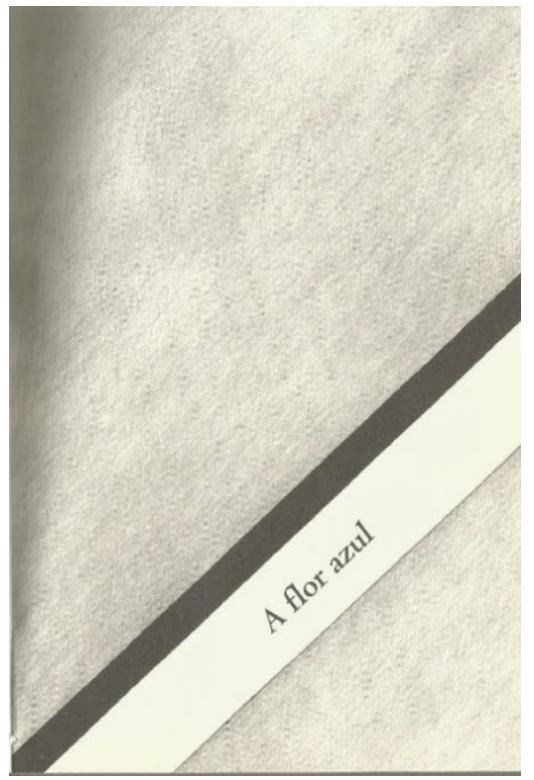

Fonte: Lygia Bojunga (projeto gráfico) (2008)

Figura 14 - Página tarjada do capítulo O tempo passando e eles conversando

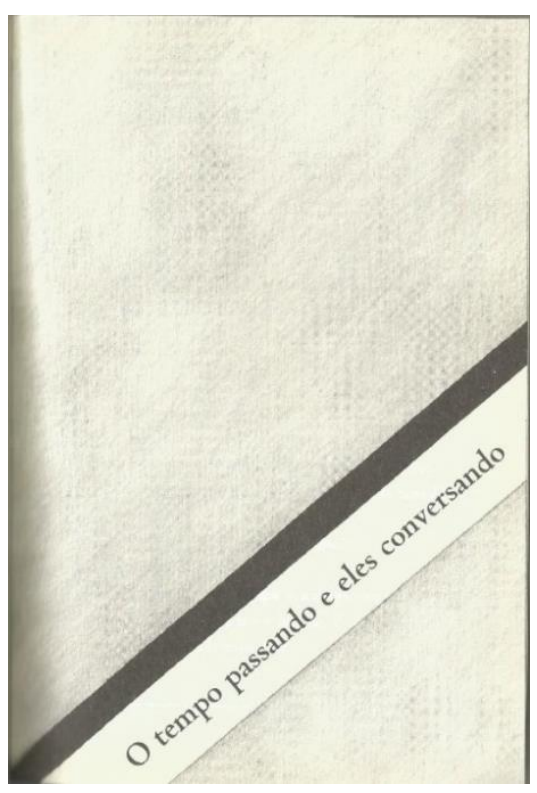

Fonte: Lygia Bojunga (projeto gráfico) (2008) 
Figura 15 - Página tarjada do capítulo Outra vez a Flor Azul

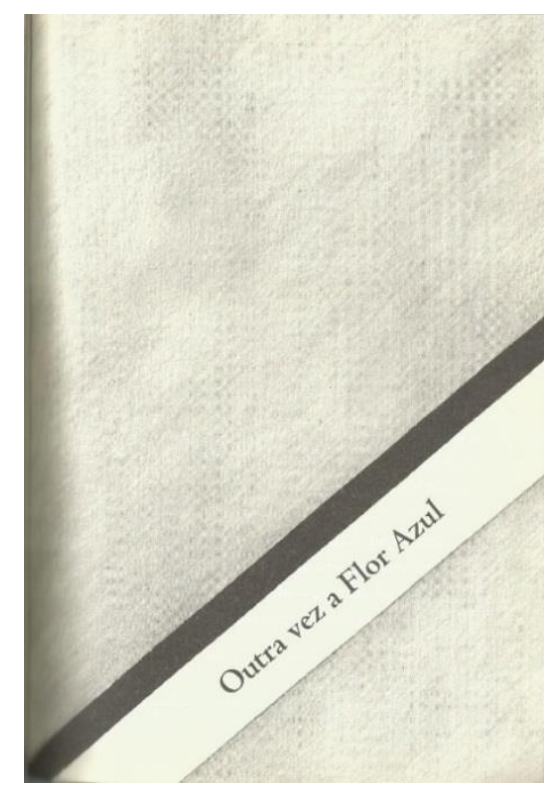

Fonte: Lygia Bojunga (projeto gráfico) (2008)

Figura 16 - Página tarjada do epílogo de Nós três

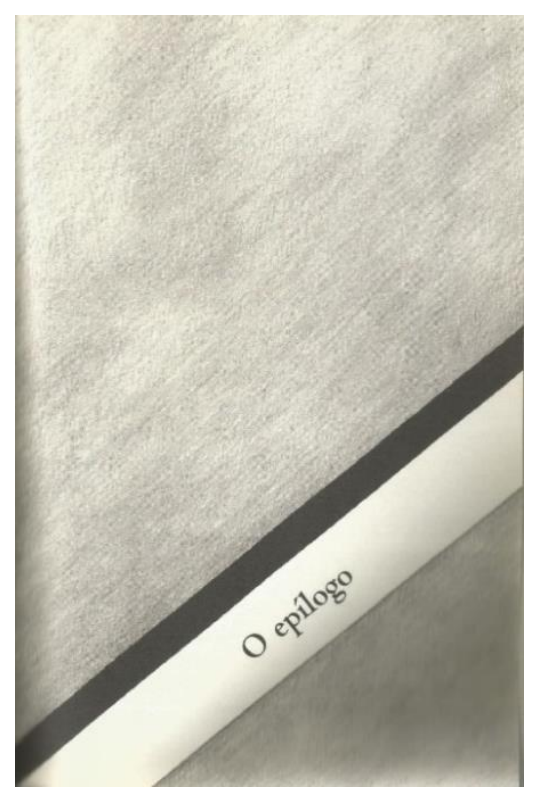

Fonte: Lygia Bojunga (projeto gráfico) (2008) 
O título da narrativa remete às personagens principais da obra: uma menina chamada Rafaela, que está passando férias escolares na praia, com Mariana, uma amiga da mãe dela; e a terceira personagem, Davi, um viajante, que para naquele local por curiosidade e atração ao mesmo tempo. Rafaela encontra Davi e conversa com ele, o que resulta em uma amizade instantânea, a ponto de Rafaela levá-lo para conhecer Mariana, que é escultora. A artista e Davi apaixonam-se, mas, em um determinado momento da narrativa, Davi sente saudades da sua vida de aventuras e decide deixar sua amada, que, tomada por um ato irracional, mata Davi para que ele não a deixe.

Essa narrativa, assim como em $O$ abraço, é repleta de referências à Morte por meio do uso da oposição entre escuridão e claridade. Já nas primeiras páginas:

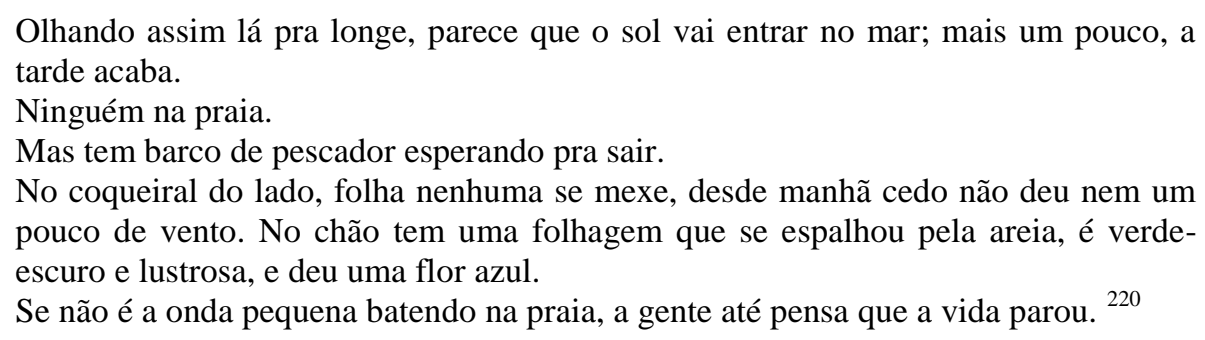

O cenário é narrado e caracterizado com a imagem de o sol se pondo, já no período do entardecer, o que sugere que a claridade está sendo tomada pela escuridão. Na sequência, descreve-se a impressão de ausência de vida na praia: tanto de pessoas quanto dos elementos da natureza, como a fauna e a flora.

Após essa cena, surge a personagem Rafaela, que está procurando um presente pela praia para levar para Mariana e lembra-se de algumas histórias que o Pescador lhe contou:

E ele contou um tal casamento que a chuva tinha feito com o sol e que não tinha dado muito certo.

Contou que um peixe (grande assim) chegava ao anoitecer numa onda grande assim querendo encontrar uma menina que ele andava procurando pra levar pro fundo do mar.

Contou que a Morte andava a cavalo e que ela gostava de galopar. Onde ela passava, um vento grande levantava, e, se tinha flor no caminho, a pata do cavalo amassava. Contou que no coqueiral tinha uma folhagem rasteira que dava uma flor azul. A flor era grande e bonita: guardava lá dentro dela o Amor. Contou que a Morte adorava essa flor, e quando via ela de longe já gritava pro cavalo, não pisa naquela flor que ela é minha! $!^{221}$

\footnotetext{
${ }^{220}$ BOJUNGA, Lygia. Nós três. 4 ed. Rio de Janeiro: Casa Lygia Bojunga, 2008, p. 7.

${ }^{221}$ Ibid., p. 8 e 9.
} 
Todas as histórias do Pescador, nas quais muita gente desacreditava, tornam-se verdades de acordo com o decorrer do livro. Em primeiro lugar, há a comprovação da história sobre casamento da chuva com o sol, que seria a união entre, respectivamente, Mariana e Davi. Como ela o mata, representa a Morte, a ausência do sol. Já Davi, que carrega consigo a flor azul, como presente de Rafaela, é morto pela escultora. Considerando que a flor representa o Amor, e a Morte procura por esta, Davi acaba sendo a vítima, decorrente da relação afetiva que estabelece com Mariana. Em segundo lugar, a história do peixe que chegava ao anoitecer procurando uma menina remete a um sonho de Rafaela, que vai até o fundo do mar buscar Davi e lá se encontra com o Cação-Anjo. Já a terceira narrativa diz respeito à história central da obra: a Morte chegando para buscar a flor azul. Ao se desfazer a metáfora, percebe-se que é a narrativa da morte de Davi.

No segundo capítulo, em que os três se conhecem melhor, há a predominância do sol, das luzes, que indicam, portanto, a vida, sobretudo, pelo processo de criação da escultura. Mariana resolve esculpir Davi em uma pedra, afirmando que seria seu melhor trabalho, o que é uma referência direta à obra Davi, de Michelângelo. Essa referência permite afirmar que a escolha dos nomes das personagens não é aleatória. Rafaela é a referência ao pintor contemporâneo de Michelângelo, Rafael.

Quando Mariana esculpe Davi, há muito sol:

Hmmm, que cheiro forte que tá o mar. E o sol ainda tão quente a essa hora, não é? Coisa boa de sentir ele no corpo; e ir afundando o pé assim na areia.

- Você já tá superqueimado.

- Eu sinto aqui, é, aqui na boca, o gosto disso tudo.

(...)

- É, é! E da noite que vai ser, e da manhã que vai aparecer, e dessa areia molhada, e desse caranguejo que deu as caras por aqui, nada disso custa um tostão e tudo isso tem um gosto tão forte, é gosto da vida, Rafa, você não sente ele aqui? ${ }^{222}$

Nesse mesmo dia ensolarado, com várias referências à vida, o assunto Morte aparece, todavia como forma de celebrar a continuação da existência, por meio da arte:

- Pensa, Rafa, pensa. Ela pega um pedaço de madeira e começa a tirar vida de lá. Você diz que agora ela vai me tirar de dentro de um bloco de pedra. Já pensou? Muito depois d'eu ter morrido (muito mesmo: pedra é uma coisa que dura toda a vida), eu vou continuar existindo. ${ }^{223}$

\footnotetext{
${ }^{222}$ BOJUNGA, Lygia. Nós três. 4ed. Rio de Janeiro: Casa Lygia Bojunga, 2008, p. 40 e 41.

${ }^{223}$ Ibid., p. 42.
} 
No entanto, quando o romance apresenta a reviravolta que desfaz felicidade sentida pelos três em estarem vivendo como uma família, as referências à escuridão voltam, tal como no início da obra:

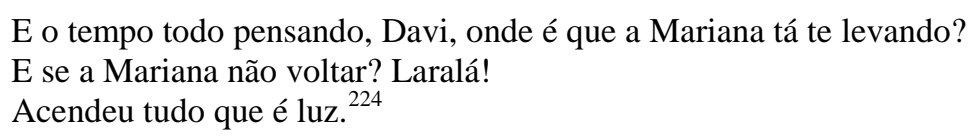

Esse trecho retrata o momento em que Rafaela aguarda o retorno de Mariana, que havia saído com o corpo de Davi rumo ao mar. Da mesma maneira em que ocorre em $O$ abraço, a personagem sente medo do escuro e, por isso, prefere acender as luzes, similarmente ao que ocorre, também, com Lucas, da obra Seis vezes Lucas. É como se o escuro fosse um antecipador de alguma tragédia, e, por isso, tende a ser evitado pelas personagens.

Nesse momento da narrativa, Rafaela resolve escrever uma carta para mãe, contando o que aconteceu, mas escreve de diversas formas, sem encontrar, com sucesso, a que melhor expresse o que está se passando naquele momento. Por essa razão, decide escrever um telegrama, que é mais conciso. Nesse momento da narrativa, há também referências à escuridão e à claridade:

Ficou arrumando o telegrama na cabeça.

Lá fora o céu ia clareando, mas assim, toda trancada, toda encolhida, só parando de escrever carta e telegrama pra cantarolar, a Rafaela nem prestou atenção na luz que ia chegando. 225

O medo não permite a personagem perceber que o problema já estava para se resolver, que, no outro dia, ela já iria voltar para a casa dela. Assim sendo, ela continua escrevendo:

Eu quis demais ir lá na vila, mas não dá pra sair assim no escuro sozinha, mas o pior não é isso, o pior é que se eu saio e ela chega sem eu ver, eu não vou ficar sabendo se... se... ah, mãe, socorro, pelo amor de Deus, vem depressa me buscar. ${ }^{226}$

Novamente há a menção ao escuro da noite, momento em que Davi foi vítima de um homicídio passional e que Rafaela não tem coragem de tomar nenhuma atitude, somente a de tentar expressar sua subjetividade por meio de cartas ou telegramas para a mãe, mostrando-lhe a sua impaciência diante da possibilidade de Davi ter realmente falecido.

\footnotetext{
${ }^{224}$ BOJUNGA, Lygia. Nós três. 4 ed. Rio de Janeiro: Casa Lygia Bojunga, 2008,p.85.

${ }^{225}$ Ibid., p. 89.

${ }^{226}$ Ibid., p. 91 .
} 
O medo de Rafaela acaba adormecendo, o que a leva a tomar uma atitude, pelo menos em sonho. Vai até o fundo do mar buscar Davi. Lá tenta, juntamente com este, elaborar um plano para que o assassinato nunca ocorra: Rafaela precisa esconder a faca antes de esta ser usada para matar Davi ou manter Rafaela ocupada:

'Como é, Mariana, quando é que você vai me acabar?'

A Mariana rindo: 'Quando eu acabar de fazer o teu cabelo você vai estar pronto, Davi.'

'Mas o meu cabelo não é assim...'

'Mas é assim que eu quero ele. Eu não sou uma copiadora, eu sou uma criadora, então eu vou fazer o teu cabelo do meu jeito. Eu adoro o sol e eu vou fazer a tua cabeça feito um sol: raios no lugar do cabelo!' E riu. E continuou cortando na pedra uns riscos pra cá e prá lá.

Pra cá e pra lá.

Pra cá e de repente a mão dela parava no meio de um risco! Não acabava aquele raio. Nem aquele nem nenhum outro.

Tudo que é bloco de pedra que ela tinha comprado e que tinha chegado na semana passada ficava jogado lá no canto da sala porque nunca mais a mão dela ia poder trabalhar.

Parada pra sempre.

O resto todo da Mariana vivendo, mas a mão parada, sem poder mais tirar a vida de nada. 227

Nesse trecho, percebe-se que uma das tentativas de manter a mão assassina de Mariana ocupada é fazê-la estar eternamente esculpindo raios de sol na estátua de Davi, metáfora esta relacionada à vida. É a mão que dá a vida, não a morte. A título de curiosidade, a imagem utilizada na capa do livro editado pela Casa Lygia Bojunga é a de uma pintura de um artista chamado Carlos Pertuis. A pintura faz parte do acervo do Museu de Imagens do Inconsciente, museu este que, em seu site, apresenta a seguinte informação sobre o pintor:

Certa manhã, raios de sol incidiram sobre um pequeno espelho de seu quarto: o brilho extraordinário deslumbrou-o, e surgiu diante de seus olhos numa visão cósmica - "O Planetário de Deus" -, segundo suas palavras. Gritou, chamou a família, queria que todos vissem também aquela maravilha que ele estava vendo. (...) A visão do "Planetário de Deus" ficou para sempre gravada. Logo que teve oportunidade de pintar, oito anos depois da incandescente visão, Carlos, movido por forte necessidade interna, tentou representá-la sobre o papel com os meios precários de que dispunha, ele, um sapateiro que nunca havia pintado. O centro da imagem é uma flor de couro, símbolo do sol e da divindade. A visão de Carlos é uma espantosa mandala macrocósmica, uma imagem do universo. ${ }^{228}$

Esta é a pintura de Carlos Pertuis:

\footnotetext{
227 BOJUNGA, Lygia. Nós três. 4 ed. Rio de Janeiro: Casa Lygia Bojunga, 2008, p.117 e 118.

${ }^{228}$ CENTRO CULTURAL MINISTÉRIO DA SAÚDE. [homepage]. Museu de Imagens do Inconsciente.

Disponível em: http://www.ccs.saude.gov.br/cinquentenario/carlos.html. Acesso em 01 ago. 2019
} 
Figura 17 - Planetário de Deus

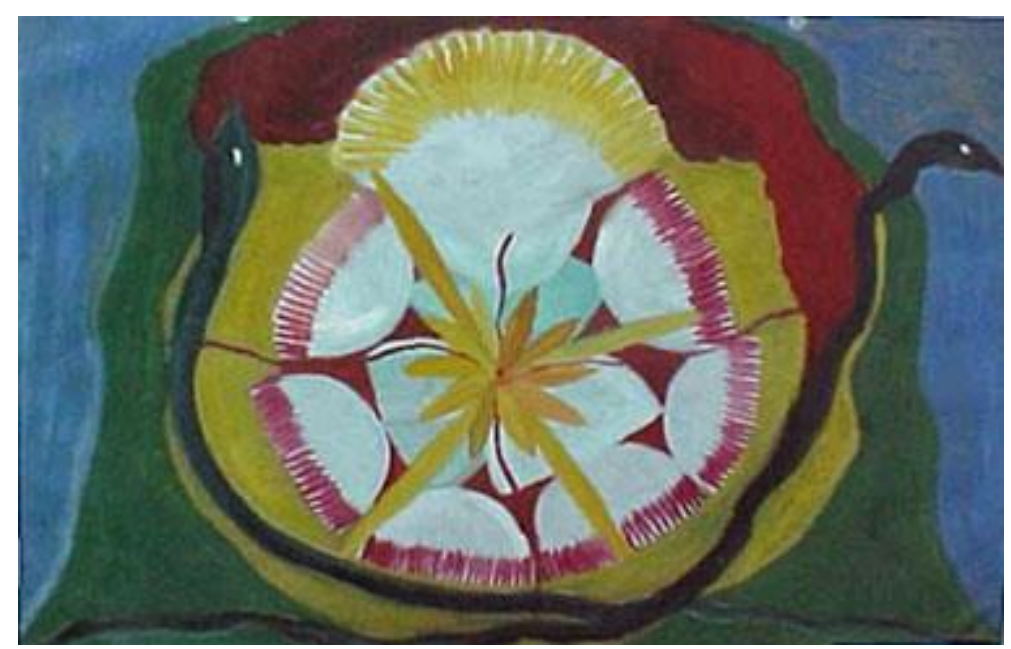

Fonte: http://www.ccms.saude.gov.br

Essa pintura remete não somente à flor, que é a metáfora, na obra de Bojunga, da vida e também da morte, mas também aos raios de sol, tão importantes para a inspiração desse pintor. No trecho do romance, os raios de sol esculpidos em forma de cabelo seriam uma das possibilidades de manter Davi vivo.

A maior parte da obra desse pintor relaciona-se ao sol. Em uma de suas últimas obras antes de sua morte, aparece a imagem do sol e de uma barca, tal como na obra de Bojunga: o sol como metáfora de vida, a barca como metáfora de travessia da vida para a morte. Essa travessia, na obra fica clara por causa da imagem da barca sendo usada para levar o corpo de Davi para o mar e para levar, também, Mariana, como é afirmado no epílogo do livro: “Até que um dia, cansada daquilo, a mulher fechou a casa e saiu no barco.

Ninguém sabe pra onde é que ela foi”. 229

Sugere-se a morte da mulher, Mariana, já que a página seguinte ao fim da narrativa é negra ou, pode-se pensar, também, que, por não haver uma tarja na página - a tarja que a autora utiliza para simbolizar a morte -, ela ainda esteja viva, vivendo no mar, tal como Davi gostaria de ter tido a sua vida.

${ }^{229}$ BOJUNGA, Lygia. Nós três. 4 ed. Rio de Janeiro: Casa Lygia Bojunga, 2008, p.134. 
Figura 18 - Páginas finais de Nós três

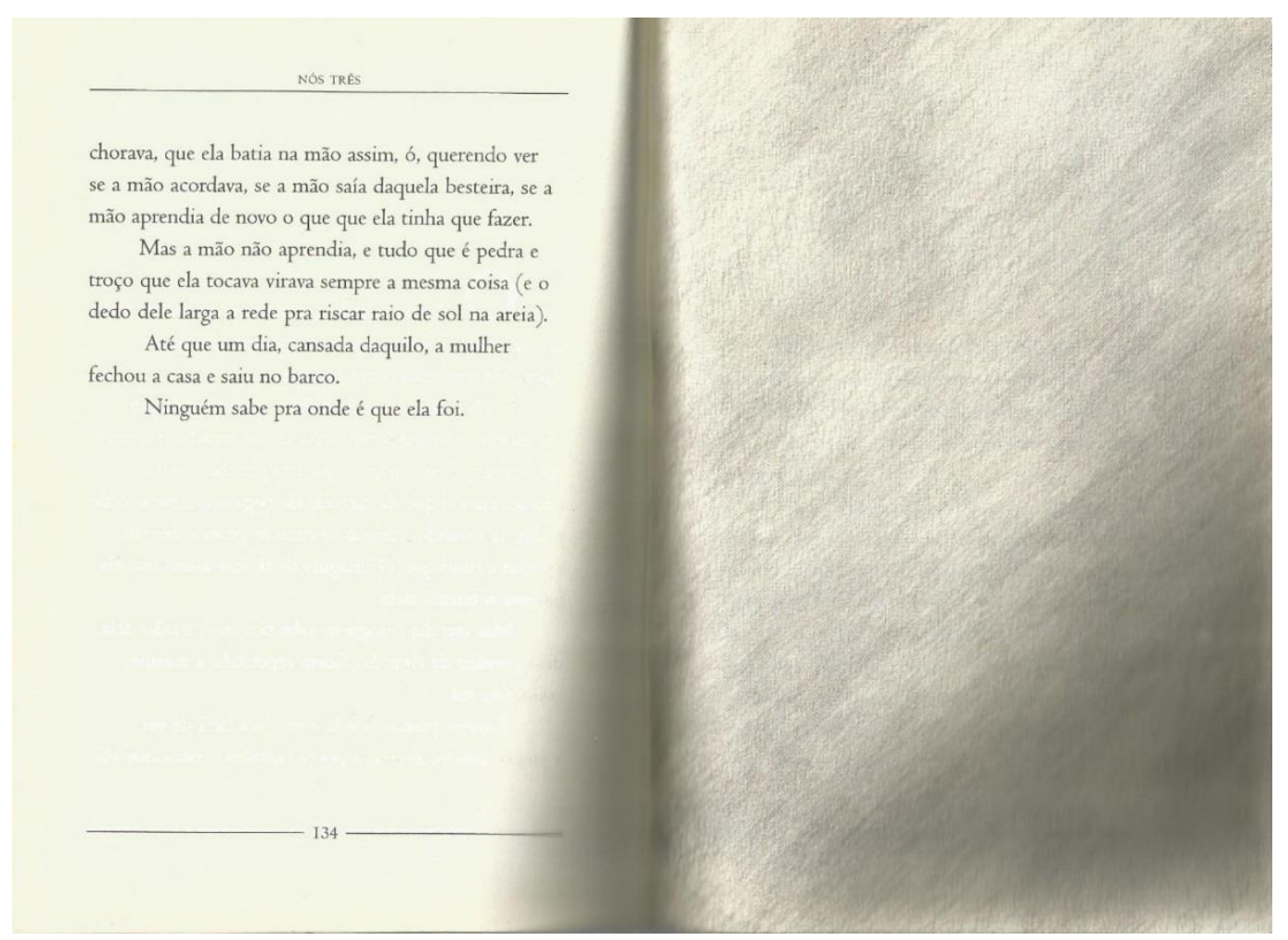

Fonte: Lygia Bojunga (2008)

Como uma obra do pintor foi usada para a ilustração da capa e como parte da história de suas pinturas relacionam-se com a obra de Bojunga, vale apena ver a pintura "A barca do sol" e o comentário do site do museu acerca dela:

Figura 19 - Barca do Sol

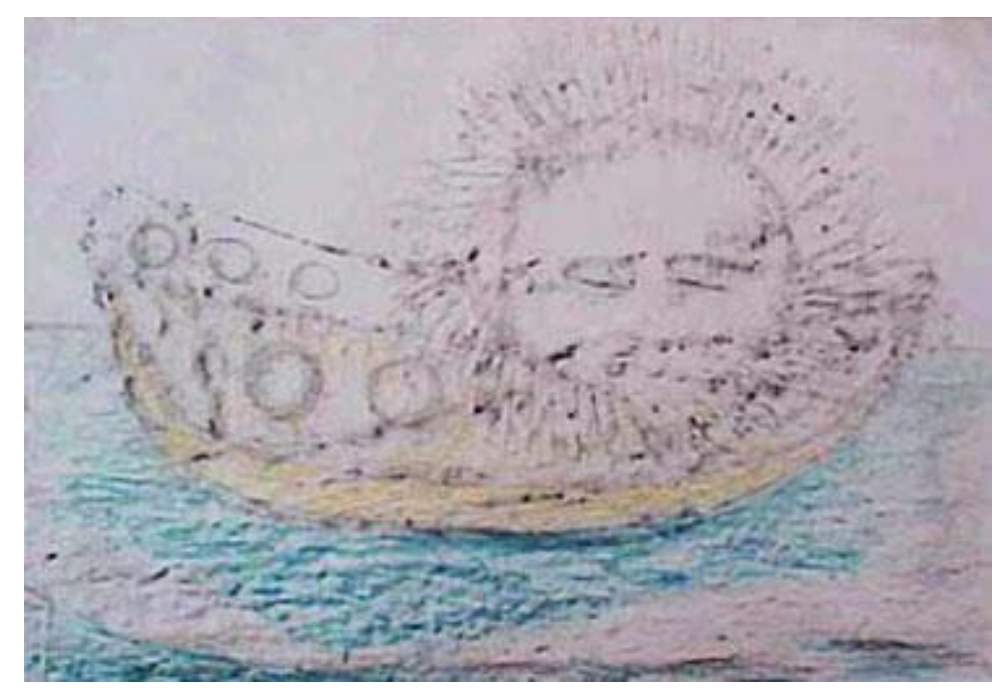

Fonte: http://www.ccms.saude.gov.br

Quatro meses antes de sua morte configura a barca do sol, presente em numerosos mitos. "A face do sol é serena e triste. Ele vai navegar na noite e lutar contra os monstros que incessantemente esforçam-se por impedir seu renascimento. Através 
de longos percursos na escuridão, tal como aconteceu a Carlos, surge, como um fio condutor, fio tênue que às vezes parece ter-se partido e ter sido tragado pelo abismo, o "Princípio de Horus", isto é, o impulso para emergir das trevas originais até alcançar a experiência essencial da tomada de consciência. ${ }^{230}$

A ideia de a barca poder propiciar o renascimento tem relação com a cena em que Mariana está com o corpo de Davi no barco. Antes de Mariana jogar o corpo dele no mar, ficou junto a ele olhando as estrelas do céu, como um tipo de despedida. Porém, com o passar da noite, ficou, do céu, somente a escuridão: “Aqui e ali sumia estrela. Da lua ficou assim só uma espécie de sombra." ${ }^{231}$, sombra esta que remete à despedida também corpórea de Davi, já que Mariana precisa se livrar do corpo.

Após concluída a análise do Teatro de Animação, passa-se à última análise, que relaciona os recursos do Metateatro à conciliação do projeto de arte e de vida de Lygia Bojunga.

230 CENTRO CULTURAL MINISTÉRIO DA SAÚDE. [homepage]. Museu de Imagens do Inconsciente. Disponível em: http://www.ccs.saude.gov.br/cinquentenario/carlos.html. Acesso em 01 ago. 2019.

${ }^{231}$ BOJUNGA, Lygia. Nós três. 4 ed. Rio de Janeiro: Casa Lygia Bojunga, 2008, p. 93. 
Como aí fora a gente sempre apresenta as pessoas que nunca se viram, nós achamos que aqui no palco a gente tinha que fazer a mesma coisa. Então vamos começar. Quem está entrando é a Angélica. Oi, Angélica! Tudo bem? Olha, eu queria te apresentar o público: Taí.

Explicador, em Angélica, de Lygia Bojunga

-Olha, esta é a Nicolina. Entra, meu bem, não fica aí parada na porta feito coisa que não quer se mostrar; que que é isso, gente! este espaço também é teu. Quer dizer, é muito mais teu do que meu, tanto que é você que vai contar a tua história, é ou não é?

Lygia Bojunga

Ir ao Teatro é crescer, aprender, rir, amar, se identificar, é ler um livro com a alma...

Lell Trevisan

A literatura, como toda a arte, é uma confissão de que a vida não basta.

Fernando Pessoa 


\section{METATEATRO}

\subsection{METALINGUAGEM, METATEATRO, TEATRO DENTRO DO TEATRO E AUTOFICÇÃO}

Algumas obras de Lygia Bojunga são criadas por meio da metalinguagem, visto que explicam a maneira por meio da qual foram escritas. Adicionando a isso a perspectiva teatral da presente análise, pode-se aproximar essa linguagem literária metalinguística a recursos que constituem o Metateatro. Para que essa aproximação seja possível, cabe destacar, previamente, que, de toda a obra publicada da autora até o presente momento, somente três apresentam textos comprovadamente teatrais: Angélica, Livro - um encontro e Intramuros. Sendo assim, para serem analisadas outras duas obras também de características metalinguísticas - Fazendo Ana Paz e Paisagem -, será fundamental comparar, em termos de recursos teatrais e de recursos literários, o rompimento entre canal (livro e palco) e receptor (leitor e plateia).

Antes de se fazer tal aproximação, define-se Metateatro como "teatro cuja problemática é centrada no teatro que 'fala', portanto, de si mesmo, se 'auto representa"232

Faz-se importante conhecer também a definição de Teatro Dentro do Teatro:

Tipo de peça ou de representação que tem por assunto a representação de uma peça de teatro: o público externo assiste a uma representação no interior da qual um público de atores também assiste a uma representação. ${ }^{233}$

É fundamental, portanto, distinguir o Metateatro do Teatro Dentro do Teatro:

A diferença entre ambas as formas é que no Teatro Dentro do Teatro, como visto em Sonhos de Uma Noite de Verão, o teatro não constitui o assunto principal do drama, senão apenas mais um artifício para trazer o tema principal à tona; já no Metateatro, como visto em Seis Personagens à Procura de um Autor, o próprio fazer teatral da época e as suas problemáticas constituem o tema principal da peça. ${ }^{234}$

\footnotetext{
${ }^{232}$ PAVIS, Patrice. Dicionário de teatro. São Paulo: Perspectiva, 2015, p.240.

${ }^{233}$ Ibid, p.385-386.

${ }^{234}$ DINIZ, Amorim Arthur. Metateatro, monodrama e o papel do dramaturgo em um processo colaborativo, Disponível em: https://www.eba.ufmg.br/cadernodeencenacao/index.php/revista/article/viewFile/35/34. Acesso em: 05 mai. 2019.
} 
O Dicionário de Teatro de Pavis não se refere fortuitamente a essas duas peças para fazer a distinção entre Metateatro e Teatro Dentro do Teatro. Shakespeare é um dos teatrólogos estudados por Lionel Abel, uma das principais referências no campo dos estudos de Metateatro, ao passo que Manfred Schmeling, outra referência nessa área, analisa o trabalho de Pirandello. Tendo em vista a importância desses autores, é essencial partir de suas concepções sobre o Metateatro:

Lionel Abel (1968) trata do metateatro como uma forma dramática localizada de modo explícito no século XVII, na obra Hamlet de Shakespeare (ainda classificada naquela época como tragédia). Para Abel, o metateatro se apresenta tanto em um campo mais simples (em que há uma peça inserida dentro de outra), como também em um campo complexo e abstrato, no qual as personagens adquirem consciência dramática, passando assim a perceber aspectos próprios do teatro, ou agem como diretores dramatizando personagens e cenas. Já para Manfred Schmeling (1982), o metateatro, fortemente presente em obras de autores como Luigi Pirandello e Molière, estaria classificado em a) formas completas: peça-dentro-de-outra-peça, sendo os atores que representam na peça moldura os mesmos - ou não - dos da peça intercalada; e b) formas periféricas, constituídas por recursos não obrigatoriamente reflexivos e críticos como prólogo, coro, epílogo (com reflexão sobre a peça), aparte (diálogo direto com o público) e presença de um diretor ou de personagens com consciência dramática. ${ }^{235}$

Nota-se que, para ambos os autores, a obtenção da consciência dramática da personagem é um recurso caracterizador do Metateatro. Essa consciência ocorre, porque, no Metateatro, há a flexibilização de fronteiras internas e externas à peça:

Do mesmo modo que as fronteiras entre quem dirige e quem encena, quem representa e quem é representado tornam-se tênues com o desenrolar da ação de Seis personagens..., também os limites entre palco e plateia são desestabilizados, reconfigurando o espaço teatral convencional na modernidade estética de reavaliar o estatuto do teatro no princípio do século XX e sua condição de simulacro do mundo real. ${ }^{236}$

Por meio desse rompimento, as personagens tornam-se conscientes de sua condição fictícia, podendo refletir sobre a peça, travar diálogos com o diretor desta ou mesmo conversar com o público.

Na literatura, por se tratar de uma arte que não é audiovisual, a narrativa, mesmo que predominantemente realizada em diálogos, necessita de um narrador. No caso das obras

\footnotetext{
${ }^{235}$ PASCOALATI, Sônia Aparecida Vido; NEVES, Vanderson de Souza. O metateatro na obra O rei da vela de Oswald de Andrade: criação de uma gramática de recursos metateatrais. Artigo disponível em: http://www.uel.br/eventos/sepech/sepech08/arqtxt/resumos-anais/VandersonSNeves.pdf. Último acesso em: 22 jun.2019.

${ }^{236}$ PASCOALATI, Sonia Em busca de uma poética Pirandelliana. Olho d’água, São José do Rio Preto, 3(1): 1190, 2011, p.98-99.
} 
literárias metalinguísticas, é muito comum a discussão sobre o método da escrita ser abordada pelo próprio narrador que, muitas vezes, pode ser o próprio autor ou se confundir com ele:

O narrador-autor faz uma reflexão sobre o fazer literário, e escrita ficcional, sobre este espaço criador que permite a irrealidade - também em segundo grau - de modo a fazer co-existirem vários planos da ficção e romper a empatia entre o mundo do livro e o mundo do leitor." (Josef, 1980:63) p. $196^{237}$

Nesse sentido, a literatura metalinguística desdobra-se em vários planos, sendo um deles, em algumas obras de Lygia Bojunga, o da autoficção, que "é um gênero que embaralha as categorias de autobiografia e ficção de maneira paradoxal ao juntar, numa mesma palavra, duas formas de escrita que, em princípio, deveriam se excluir". ${ }^{238}$

Livro - um encontro, Fazendo Ana Paz, Paisagem e Intramuros são obras que, além de terem muitas características metalinguísticas, apresentam características da autoficção, uma vez que o processo de escrita da autora parte dela mesma: "O eu da escritora é o ponto de referência maior; o preencher de sua necessidade de auto-conhecimento. A partir daí todo texto é recontado." 239

Considerando-se tanto os recursos metalinguísticos literários relacionados à autoficção quanto os metateatrais, nota-se a aproximação entre todos esses recursos artísticos:

\begin{abstract}
A autoficção é uma máquina produtora de mitos do escritor. Essa máquina funciona tanto nas passagens em que se relatam vivências do narrador quanto naqueles momentos da narrativa em que o autor introduz no relato uma referência à própria escrita, ou seja, a pergunta pelo lugar da fala: o que é ser escritor? Como é o processo da escrita? Quem diz eu? (KLINGER, 2012, p. 46). É nas duas primeiras questões que o metateatro se cruza inevitavelmente com a autoficção; isto é, tanto pelo gênero autoficção, quanto pela presença do metateatro, a escrita, a criação literária está se indagando sobre seus limites, funções, modo de criação e recepção. $^{240}$
\end{abstract}

Dada a relação entre Metateatro, autoficção e metalinguística, passam-se a analisar especificamente as obras de Lygia Bojunga a partir dos conceitos já mencionados.

\footnotetext{
${ }^{237}$ MENDES, Maria dos Prazeres Santos. Monteiro Lobato, Clarice Lispector, Lygia Bojunga Nunes: o estético em diálogo na literatura infanto-juvenil. 1994. 265 f. Tese (Doutorado em Comunicação e Semiótica) - Pontifícia Universidade Católica de São Paulo. 1994.

${ }^{238}$ FIGUEIREDO, E. Autoficção feminina: a mulher nua diante do espelho. Revista Criação \& Crítica, n. 4, p. 91-102, 15 abr. 2010.

${ }^{239}$ Ibid, p. 178.

${ }^{240}$ LIMA, Augusto de; PASCOLATTI, Sonia. Autoficção como recurso metateatral em Fernando Abreu, Ricardo Scripta Uniandrade, Curitiba, PR, v. 12, n. 1 (2014), p. 106-123. Data de edição: 27 jun. 2014.
} 


\subsection{METATEATRO E TEATRO DENTRO DO TEATRO: ANGÉLICA}

Aplicando-se essas distinções à obra bojunguiana, pode-se dizer que Angélica é uma obra que apresenta, literalmente, um Teatro Dentro do Teatro. Afirma-se que esse seja um texto de teatro, pois, além de a obra ser dividida em pequenas partes -partes essas que não são chamadas de capítulos, como em Os colegas -, sendo os títulos numerados com algarismos romanos (o que é comum ocorrer com numerações de cenas de teatro), há notas de rodapé que comentam as falas das personagens ou às do próprio narrador, tal como a função do coro. Ademais, o fim da narrativa central coincide com a ideia geral do segundo ato da peça Angélica junto à família e seguindo sua vida como achava que deveria ser -, o que leva a não ser retratada a representação do segundo ato dessa peça, já que o último capítulo, que é sobre os bastidores do dia da encenação, termina durante o intervalo, momento em que o irmão da protagonista a visita.

É um Teatro Dentro do Teatro, já que dentro dessa narrativa central, há a reprodução de uma peça teatral, que foi escrita pela protagonista da obra: Angélica. A fim de mostrar claramente os limites entre ambas, Lygia Bojunga escreve a peça de teatro (Teatro Dentro do Teatro) como gênero: a divisão em atos; a presença de um "explicador", que funciona como o narrador da peça; o diálogo antecedido pelo nome das personagens:

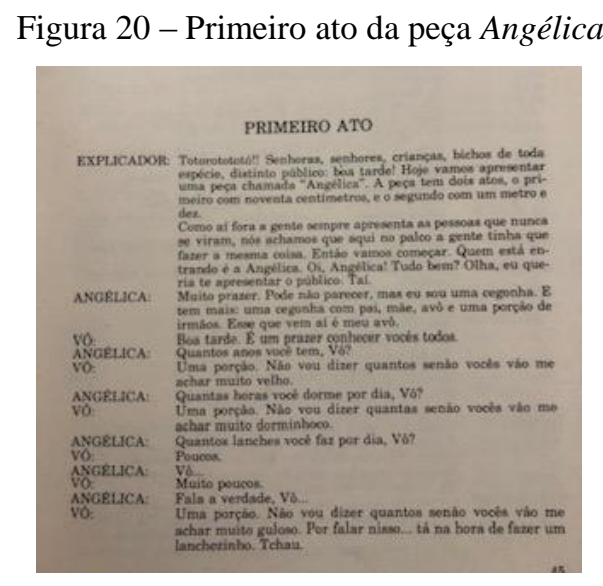

Fonte: Lygia Bojunga (1975)

É, literalmente, um texto teatral dentro da narrativa central.

Além disso, partindo-se do pressuposto de que há, literalmente, um texto teatral dentro da obra, há outros recursos metateatrais que são utilizados nessa obra, dentre eles: 
1) A explicitação dos bastidores de todo o processo que antecede a apresentação da peça:

a) O processo de escrita das cenas e a construção física do cenário:

Angélica e Porto então começaram a trabalhar na peça de teatro.

Todos os dias se encontravam e ficavam discutindo horas a fio como é que ia ser uma cena, como é que ia ser outra. Assim que chegavam a uma conclusão as falas que inventaram pros personagens.

(...)

[Porto] desenhou um cenário que era a frente da casa de Angélica, com porta, janela, flor nascendo no jardim, avião passando no céu.

- Ei, Angélica, eu vou arrumar um lençol bem grande pra desenhar esse cenário. Aí a gente pendura o lençol que nem cortina de chuveiro de gente que tem chuveiro. Quando a cortina abrir é pra mostrar que a gente tá entrando dentro de casa. ${ }^{241}$

b) A forma de divulgação da peça:

Figura 21 - Divulgação do horário da peça

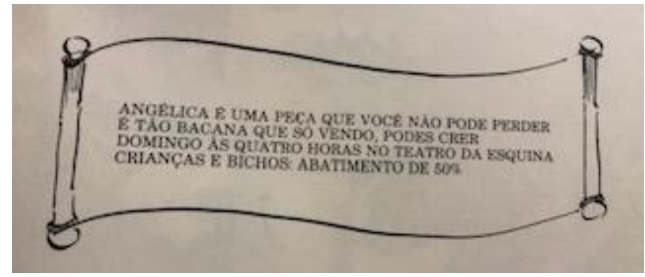

Fonte: Lygia Bojunga, ilustração de Vilma Pasqualini (1975)

Figura 22 - Divulgação da peça

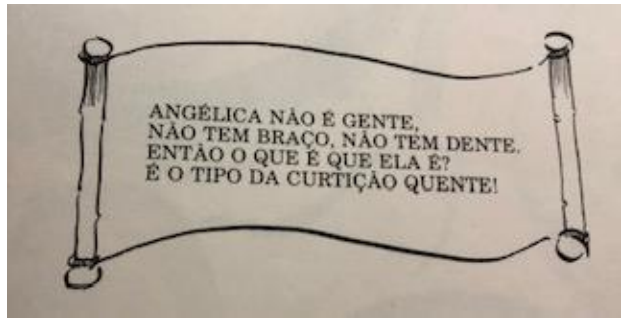

Fonte: Lygia Bojunga, ilustração de Vilma Pasqualini (1975)

c) A busca por atores, busca essa, inclusive, que desencadeia a introdução de outras personagens à narrativa central que, também, serão personagens na peça:

- Nós tamos precisando de mais atores. Você não tem nenhum amigo que quer trabalhar?

(....) - Tem o crocodilo de cinto.

${ }^{241}$ NUNES, Lygia Bojunga. Angélica. Rio de Janeiro: Agir; Brasília, INL, 1975, p.43. 
- Será que ele topa? ${ }^{242}$

d) Os ensaios, que mostram o processo de criação de caracterização de uma personagem (Mulher-do-Jota que ia trabalhar como atriz na peça) em relação à outra:

\begin{abstract}
Inventou uma roupa pra usar na peça que era da gente morrer de rir, inventou um jeito engraçadíssimo de ficar numa perna só (que nem as cegonhas ficam) balançando o corpo de um lado pra outro como se fosse cair a qualquer momento, inventou um cacoete de dar umas sacudidelas de cabeça quando menos se esperava; e depois começou a ensaiar as bolações. ${ }^{243}$
\end{abstract}

2) A explicitação dos bastidores da peça, que é a última parte da obra, intitulada "XIA representação":

a) De $\mathrm{O}$ acúmulo de trabalho e a situação psicológica dos atores:

Ele [Porto] nem podia falar direito de tão cansado. Também, coitado, desde cedo não parava - preparando as coisas que eles iam usar em cena, vendo entradas, ajudando Angélica e os outros atores a darem os últimos retoques nas roupas, acudindo Canarinho que estava tão nervoso que teve uma disparada de coração. ${ }^{244}$

b) Os imprevistos:

Canarinho é que continuava nervoso. Logo depois de se apresentar, em vez de sair para o lado, saiu pela frente: não viu os degraus que separavam o palco da platéia, se estatelou no chão e não conseguia se levantar sozinho de jeito nenhum. A peça teve que parar. (...)

O sol caiu duas vezes no chão (o prego era curto).

Rabanete engoliu uma fala.

Na hora de nascer Angélica pulou pra fora do ovo com tanta força, que um pedaço do ovo de papelão voou longe e foi cair na cabeça de uma senhora sentada na primeira fila. ${ }^{245}$

Doravante, serão analisadas as obras da trilogia de cunho metalinguístico da autora e Intramuros.

7.3. DO CUMPRIMENTO DA TRILOGIA LITERÁRIA AO CUMPRIMENTO DE UM PROJETO DE VIDA

7.3.1.Monólogo: Livro - um encontro

\footnotetext{
${ }^{242}$ NUNES, Lygia Bojunga. Angélica. Rio de Janeiro: Agir; Brasília, INL, 1975, p.70.

${ }^{243}$ Ibid., p. 80.

${ }^{244}$ Ibid., p. 160

${ }^{245}$ Ibid, p. 86 e 87.
} 
Essa obra apresenta metalinguagem inclusive nos nomes dos capítulos: $O$ que que é Livro, Livro - eu te lendo, Livro - eu te escrevendo?. Ela é primordial para o presente estudo, visto que foi redigida visando a ser encenada pela própria autora. Logo, literatura e teatro, nessa obra, são explicitamente citados pela artista.

No Pra você que me lê, Bojunga informa que: "Quando tempos depois de lançar Livro, a Editora Agir publicou Fazendo Ana Paz e, em seguida, Paisagem, escrevi um pequeno texto chamado 'Caminhos', que acompanhou cada uma daquelas duas obras." 246

Já indicando um pouco do trabalho artesanal de que tanto Lygia Bojunga gosta, o título desse texto é publicado com a própria letra da autora:

Figura 23 - Manuscrito de Livro - um encontro

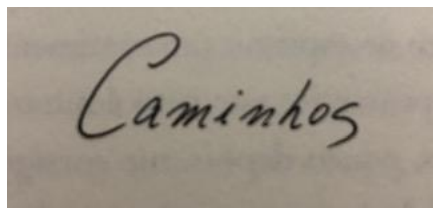

Fonte: Lygia Bojunga (2007)

Nesse texto, ela classifica sua obra como um monólogo e explica:

Quando eu escrevi e interpretei o monólogo 'Livro', falando da minha vida de leitora e contando os seis casos de amor que eu tive com obras literárias, eu estava longe de imaginar que comprido que ia ser o caminho que eu ia andar.

Depois das primeiras apresentações de 'Livro' pelo Brasil, eu comecei a achar que, fazendo a outra metade da laranja, isto é, me posicionando também como escritora, a representação do meu envolvimento com livros ia ficar mais redonda, e com isso eu quero dizer mais integrada.

Escrevi então o que chamei de 'encontros com a escrita', contando alguns episódios ligados à minha inclinação para escrever. Não levei essas narrativas pro palco: achei que elas tinham saído com cara de só gostar de morar em livro. Foram publicadas, junto com o monólogo da leitora, num volume chamado, originalmente Livro - um encontro com Lygia Bojunga Nunes. ${ }^{247}$

Há duas informações nesse trecho que serão abordadas, visto que auxiliarão a análise sobre Metateatro: o Monólogo e os “encontros”. Começando com a definição de Monólogo:

Monólogo: 1TEAT cena de peça em que o ator, achando-se só, fala consigo mesmo ou se dirige ao público, expressando seus pensamentos, as lutas interiores do seu

\footnotetext{
${ }^{246}$ BOJUNGA, Lygia Livro - um encontro. 6. ed. Rio de Janeiro: Casa Lygia Bojunga, 2007, p.95 e 96.

${ }^{247}$ Ibid., p.96 e 97.
} 
espírito etc. 2 TEAT peça escrita para um único personagem; monodrama. 3 ato de falar consigo próprio; solilóquio 4 discurso que não deixa outros falarem. ${ }^{248}$

O mesmo dicionário apresenta uma acepção literária do termo:

Monólogo interior LIT representação num monólogo ger. extenso, do fluxo da consciência de um personagem ficcional, seus pensamentos e sentimentos, habitualmente com uma desarticulação lógica dos períodos e sentenças; diálogo interior. $^{249}$

Já o Dicionário de Termos Literários define Monólogo como: "falar sozinho; mónos, único, sozinho; lógos, palavra, discurso. Peça de teatro em torno de uma só figura." 250

O Dicionário de Teatro, por sua vez, define-o da seguinte maneira:

O monólogo é um discurso que a personagem faz para si mesma. Encontra-se também o termo solilóquio.

O monólogo se distingue do diálogo pela ausência de intercâmbio verbal e pela grande extensão de uma fala descartável do contexto conflitual e dialógico. $\mathrm{O}$ contexto permanece o mesmo do princípio ao fim, e as mudanças de direção semântica (próprias do diálogo) são limitadas a um mínimo, de maneira a garantir a unidade do assunto da enunciação. ${ }^{251}$

Com base nessas definições, é possível perceber, após fazer uma leitura cronológica da obra completa de Lygia Bojunga, que o Monólogo não aparece apenas em Livro - um encontro, mas também em outros, como Fazendo Ana Paz, Paisagem, Feito à mão, O Rio e eu, Retratos de Carolina e Intramuros. Portanto, Livro - um encontro é a primeira obra em que Lygia Bojunga Nunes experimenta o monólogo. Nesse caso, este será aliado à metalinguagem, e essa combinação, feita para ser encenada, explicita muito bem a relação de amor que a autora tem com a leitura e a escrita.

O primeiro capítulo da obra explica o que é "Livro", no caso, o título do livro/peça. Essa explicação é baseada em como surgiu a ideia de criar esse projeto. Logo de início, a autora reproduz um texto, chamado "Livro: a troca", que ela escreveu em 1982 para a IBBY (Organização Internacional para o Livro Infantil e Juvenil). A reprodução de todo o texto já coloca o leitor/espectador em um segundo espaço e tempo, havendo, portanto, um Teatro Dentro do Teatro: o leitor/espectador lê/assiste (a) um monólogo, que é suspenso para que

\footnotetext{
248 HOUAISS, Antonio; VILLAR, Mauro de Sales. Dicionário Houaiss da língua portuguesa/ Antonio Houaiss e Mauro de Sales Villar, elaborado pelo Instituto Antonio Houaiss de Lexicografia e Bancos de Dados da Língua Portuguesa S/C Ltda. Rio de Janeiro: Objetiva, 2009, p.1312.

${ }^{249}$ Ibid., p. 1312.

${ }^{250}$ MOISES, Maussad. Dicionário de termos literários. São Paulo: Cultrix, 2013, p.317.

${ }^{251}$ PAVIS, Patrice. Dicionário de teatro. São Paulo: Perspectiva, 2015, 247.
} 
haja a reprodução de um outro momento em que a autora também se coloca no papel de única falante.

Na sequência, Lygia Bojunga explica que gostaria de falar mais sobre a relação dela com a obra, porém ao vivo. Ela passa a contar como foi o processo de nomeação do projeto, que, por sua vez, não é somente metalinguístico, como também metateatral:

\begin{abstract}
Mas a gente tem que acabar dando nome às coisas, e então o projeto passou a se chamar 'Livro'.

Na hora de anunciar a apresentação de 'Livro', a pergunta embaraçosa apareceu de novo, e dessa vez pressionando uma definição: 'Livro' era uma palestra? (com cara de história?), era uma história? (com cara de palestra?), e sem saber me definir com precisão eu acabei saindo pela tangente: 'Livro' é um encontro comigo. ${ }^{252}$
\end{abstract}

Esse processo é metalinguístico no plano da literatura, ao se utilizar a linguagem para explicar o processo de nomeação da obra, e é, ao mesmo tempo, metateatral, porque, ao ser encenado, a autora passa a ser uma personagem e passa a referir-se ao título de sua peça por meio da atuação. Em outras palavras, ela utiliza o monólogo para explicar como deu nome à peça que está iniciando.

Como o "monólogo é um discurso que a personagem faz para si mesma", a própria autora percebeu a relação de sua obra com o teatro, o que também é encenado, e, portanto, também é metateatral:

\footnotetext{
Mas quando eu apresentei o meu 'encontro' muita gente disse que 'Livro' era Teatro: era um monólogo. E foi aí que eu me dei conta do meu terceiro motivo, no passado, o Teatro foi componente forte nessa mistura que me resultou - componente que eu botei de lado por não ter vocação para a vida teatral.

A gente bota as experiências fortes de lado, mas elas ficam acontecidas dentro da gente; e os fragmentos delas formam um novo desenho lá no fundo do nosso caleidoscópio. $^{253}$
}

Nesse sentido, a escritora expõe o momento de tomada de consciência acerca da relação entre sua literatura e o teatro, o que demonstra não apenas que a sua obra Livro tem características marcantes da metalinguagem - já que se trata da reflexão da autora sobre a relação dela com o objeto livro, como também é metateatral, já que "o metateatro leva a atividade teatral ao patamar de atividade auto-reflexiva". ${ }^{254}$

\footnotetext{
${ }^{252}$ BOJUNGA, Lygia. Livro - um encontro. 6. ed. 2. imp. Rio de Janeiro: Casa Lygia Bojunga, 2007, p.12.

${ }^{253}$ Ibid., p.12 e 13.

${ }^{254}$ MARTINS, Pedro Haddad. O metateatro como instrumento para a formação teatral de alunos-atores entre 8 e 12 anos. 2011. 179f. Dissertação (Mestrado em Artes) - Universidade Estadual de Campinas, Instituto de Artes, p.8.
} 
A parte dessa obra intitulada "Encontros" não foi encenada pela autora, pois ela acreditava que a relação dela com a escrita não estava relacionada à de leitora:

Em Livro - um encontro, no capítulo 'Livro - eu te escrevendo'?: Uma das críticas que a Ana Lúcia fez à minha apresentação de "Livro" foi, justamente, ao aspecto básico do texto: eu me apresentava como leitora, não fazia a menor alusão ao fato de ser uma escritora também. E ela achava que o projeto ia ficar mais redondo eu falando - nem que fosse um bocadinho só- do meu convívio com a escrita.

Discutimos horas.

E quando disse que não queria misturar alhos com bugalhos, ela só faltou morrer. ${ }^{255}$

Não obstante, essa certeza mencionada nesse trecho deixou de sê-la na última página da obra, que antecede o Pra você que me lê:

(...) ainda estou olhando pros encontros com a escrita que eu contei aqui, pensando se eles misturaram bem com os meus casos de amor...

Uma hora eu acho que sim.

Outra hora eu comparo um com o outro e fico achando que o "eu te lendo" nasceu com cara de pra ser dito e o "eu te escrevendo" pra ser lido.

E aí outra hora... etc. e tal.

Mas acho que daqui a pouco vou saber qual é a hora que fica valendo. FIM 256

A partir desse trecho, fica evidente não apenas a preocupação com o processo de criação literária, como também a melhor via de expressão para cada parte da obra, se o teatro ("pra ser dito") ou a literatura ("para ser lido").

\subsubsection{Fazendo Ana Paz: criando a consciência dramática da personagem}

Essa obra é predominantemente metalinguística, desde o título que contém o verbo "fazer" no gerúndio, indicando uma ação contínua de construção da personagem Ana Paz. A primeira parte da obra é a já mencionada "Caminhos":

A necessidade de falar mais dramaticamente do ato de escrever me fez continuar nesse caminho e levantar uma personagem chamada Ana Paz. O percurso que eu fiz com a Ana Paz foi difícil, eu não enxergava bem o caminho, tropecei e parei muitas vezes, mas ele me levou a um livro que eu chamei de Fazendo Ana Paz. E me levou também a querer continuar ainda na mesma estrada. ${ }^{257}$

Sabe-se que o advérbio "dramaticamente" destacado pela autora nesse trecho diz respeito ao teatro e ao fato de essa obra ser continuidade do projeto anterior dela, As

\footnotetext{
${ }^{255}$ BOJUNGA, Lygia Livro - um encontro. 6. ed. 2. imp. Rio de Janeiro: Casa Lygia Bojunga, 2007, p. 51. ${ }^{256}$ Ibid., p. 91.

${ }^{257}$ BOJUNGA, Lygia. Fazendo Ana Paz. Rio de Janeiro: Casa Lygia Bojunga, 2013, p.97.
} 
Mambembadas. Portanto, já se tem, a partir disso, uma relação teatral, mesmo que indireta, com essa obra. Sabe-se também que a "estrada" à que Lygia Bojunga se refere é o processo da escrita, que pode ser lida como a trilogia de obras da autora destinada a unir o seu eu-leitora ao seu eu-escritora, ou a um projeto literário, que a autora viria, possivelmente, a concluir com a publicação de Intramuros, interpretação essa que será feita posteriormente.

Fazendo Ana Paz inicia-se com a autora relacionando o seu gosto pela leitura de um determinado gênero textual à sua vontade de construir uma narrativa desse mesmo gênero:

Eu sempre gostei de ler livros de viagens; um dia me deu vontade de escrever um. Fiquei lembrando dos caminhos que eu tinha andado por este mundo afora; acabei escolhendo dois ou três pra fazer o meu livro. Comecei então a pensar no jeito que eu ia usar pra viajar no papel. Quando no fim eu me sentei pra escrever o livro, saiu um bilhete assim:

'Prezado André

Ando querendo bater papo. Mas ninguém tá a fim. Eles dizem que não têm tempo. Mas ficam vendo televisão. Queria te contar a minha vida. Dá pé?

Um abraço da Raquel.'

Larguei o lápis, li e reli o bilhete, que que é isso?! que Raquel é essa que se intromete assim, de cara, na viagem que eu vou contar? ${ }^{258}$

Percebe-se, claramente, que o livro de viagens, que remete a experiências vividas e a lugares visitados, é substituído pelo começo da construção da personagem Raquel, que, por meio desse bilhete, anuncia querer contar a vida dela, isto é, a personagem será mais desenvolvida futuramente. E esse “contar a vida" tinha um destinatário, André, outra personagem. Nesse sentido, o livro de viagens, que representaria o mundo conhecido, torna-se o universo desconhecido do processo de criação literária de uma personagem e, consequentemente, de uma narrativa que já se inicia com a voz de uma protagonista de outra obra da autora, não a da atual obra.

Bojunga começa a obra referindo-se à experiência da criação da protagonista de $A$ bolsa Amarela, para dizer que Ana Paz teve presença semelhante à de Raquel, pois é praticamente uma personagem apresentando-se:

Eu me chamo Ana Paz; eu tenho oito anos; eu acho o meu nome bonito.

Tem gente que, pra andar mais depressa, me chama só de Ana. Mas se tem coisa que eu não gosto é ver meu nome pela metade. E tem gente me chamando de Pazinha. Finjo até que não escuto quando alguém me chama

${ }^{258}$ BOJUNGA, Lygia. Fazendo Ana Paz. Rio de Janeiro: Casa Lygia Bojunga, 2013, p.10 e 11. 
assim. Mas a minha mãe e o meu pai sempre me deram uma força: eu nunca ouvi eles me chamando diferente de Ana Paz.

Após essa apresentação, que, posteriormente, acompanha um trecho sobre a história da personagem, a narradora-autora reclama que não consegue desenvolver mais Ana Paz, então passa a ter "urgência de fazer uma moça" ${ }^{260}$, que a autora passou a chamar de a Moça-que-seapaixonou-pelo-Antônio.

Porém, o processo de escrita dessa personagem também não progride e surge uma terceira narrativa, que é sobre uma senhora. Para cada uma delas, há uma trama que se interliga, individualmente, à trama da narrativa principal, sendo esta a que conta o processo de criação de Ana Paz. A narradora-autora somente consegue proporcionar a intersecção e a transformação de todas essas tramas, quando pensa em um espaço: uma casa. Nesse momento, a autoficção é um recurso utilizado, como forma de demonstrar a origem do processo de criação literária de Bojunga: a partir de lembranças de espaços (casas, jardins, hotéis) pelos quais ela passou:

\footnotetext{
Mas uma coisa era certa: a velha estava indo pra cidade onde ela tinha nascido; ela ia ver de novo a casa onde ela passou a infância.

Então o encontro ia ser na casa.

Resolvi, antes de mais nada, levantar a casa.

Eu fiz ela toda de sobras. Uma sobra da casa do meu avô, outra da casa da minha tia, outra do apartamento da minha professora de inglês (...) De cada morada eu tirava um pedaço, pra ir levantando a casa onde minhas três mulheres iam se encontrar.

Fui gostando tanto de fazer a casa, que, em vez de ir pra mesa escrever, eu ficava me balançando na rede, trazendo pro meu estúdio uma porta da minha vó, um pátio da minha outra avó. Parava de fazer a casa e ia plantar no pátio um pé de jasmim que tinha no jardim da minha prima; botava num quarto da casa o guarda-roupa de espelho na porta que um dia eu encontrei num quarto de hotel; botei até na cozinha uma torneira que sempre pingava lá na casa onde eu me criei.

Deixei pra inventar a festa da cumeeira só no dia que o telhado ficou pronto: botei na minha casa o telhado limoso dum sobrado que eu vi sobrar numa rua de Recife. Agora, olhando pra trás, eu chego a pensar que eu estava tão devagar na minha história de tanto que eu vinha querendo ficar lá deitada na rede, lembrando tijolo por tijolo a casa onde a velha ia ter nascido. ${ }^{261}$
}

Nota-se que a primeira vez que a narradora-autora usa o verbo "levantar a casa", ela se refere à casa ficcional da narrativa da velha. Entretanto, na segunda vez já se percebe a relação da narradora-autora com a casa e como ela a constrói, cômodo a cômodo. Todo esse processo é oriundo do campo do imaginário, que, por sua vez, relaciona-se ao campo da

\footnotetext{
${ }^{259}$ BOJUNGA, Lygia. Fazendo Ana Paz. Rio de Janeiro: Casa Lygia Bojunga, 2013, p.14.

${ }^{260}$ Ibid., p.18.

${ }^{261}$ Ibid., p.35 e 36.
} 
ilusão ${ }^{262}$, campo esse que é desfeito, ao longo da obra pela narradora-autora como será analisado também posteriormente, ao revelar todo o processo de criação literária:

Cabe a Lygia destruir essa ilusão, essa trama de fantasias ao revelar os meandros da passagem do imaginário ao simbólico em seu processar sígnico específico: sua invenção da invenção: representação da representação. ${ }^{263}$

Sabe-se que essa é a casa que a narradora-autora escolheu para ser a residência da senhora, pois ela afirma que ficou "lembrando tijolo por tijolo a casa onde a velha ia ter nascido". ${ }^{264}$ Nesse sentido, tanto a autoficção como a narrativa central complementam-se de modo a se ter o espaço descrito da autoficção - uma forma de representação - representando o espaço de outra ficção - a narrativa central da obra.

Muito próxima a essa análise literária sobre a destruição das ilusões nas narrativas de cunho metalinguísticos de Bojunga, há um recurso do Metateatro, mais especificamente do Teatro Dentro do Teatro, que é a superilusão. Esta começa a ser mais latente após a construção da casa, pois a narradora-autora escreve o encontro das três personagens, revelando e percebendo, junto com o leitor, que todas são a mesma, porém em épocas diferentes da vida. Aparentemente, todo o enredo da obra se revela.

O leitor acompanha a obra Fazendo Ana Paz de acordo com o ponto de vista da narradora, que é a autora. Como esta conta o processo de criação de personagens e de narrativas - processo este incompleto, desordenado, não cronológico -, o surgimento de outras mininarrativas dentro da narrativa central cria um jogo de superilusão, que é típico do Teatro Dentro do Teatro:

O emprego desta forma corresponde às mais diversas necessidades, mas sempre implica uma reflexão e uma manipulação da ilusão. Mostrando, em cena, atores dedicando-se a interpretar a comédia, o dramaturgo implica o espectador 'externo' num papel de espectador da peça interna e restabelece, assim, sua verdadeira situação: a de estar no teatro e apenas assistir a uma função. Graças a esse desdobramento da teatralidade, o nível externo adquire um estatuto de realidade ampliada: a ilusão da ilusão passa a ser realidade. ${ }^{265}$

Da mesma maneira que no Teatro Dentro do Teatro o espectador externo é colocado como espectador da peça interna, na obra de Lygia o leitor é colocado como leitor de várias

\footnotetext{
${ }^{262}$ MENDES, Maria dos Prazeres Santos. Monteiro Lobato, Clarice Lispector, Lygia Bojunga Nunes: o estético em diálogo na literatura infanto-juvenil. 1994. 265 f. Tese (Doutorado em Comunicação e Semiótica) - Pontifícia Universidade Católica de São Paulo. 1994, p. 183.

${ }^{263}$ Ibid., p. 184.

${ }^{264}$ BOJUNGA, Lygia. Fazendo Ana Paz. Rio de Janeiro: Casa Lygia Bojunga, 2013, p. 36.

${ }^{265}$ PAVIS, Patrice. Dicionário de teatro. São Paulo: Perspectiva, 2015, p. 386.
} 
narrativas internas - por ter que seguir vários narradores-personagens e tramas -, o que cria a primeira ilusão, ilusão essa fragmentada, mas que vai tendo seus fragmentos concatenados pelas interferências da narradora-autora que, o tempo todo, trás de volta o leitor para a narrativa central, que é a construção da personagem Ana Paz. O entrecruzamento dessas tramas explicita a primeira ilusão da ilusão: o enredo da narrativa teria sido definido. Essa parece ser a realidade sobre a narrativa de Fazendo Ana Paz; porém, é uma ilusão, pois, ao se ver diante das variadas tentativas sem êxito de criar um pai para a protagonista, - o que fez a narradora-autora voltar ao início da obra -, Ana Paz torna-se inconclusa. É nesse jogo de realidade que se amplia cada vez mais, por meio da ruptura de ilusões que a narradora-autora cria, que a protagonista da obra ganha definitivamente a dramaticidade, mencionada no texto “Caminhos". Essa dramaticidade não apenas dá vida à personagem, que não mais está emoldurada apenas na trama que conta a sua vida, mas também proporciona autonomia a ela, a ponto de ser ela quem decide o seu final inconcluso. A personagem ter consciência de seu papel de personagem, além de ser um recurso metalinguístico, é um recurso metateatral, visto que essa rompe com sua consciência dramática.

Esse rompimento leva à pluralidade de vozes narrativas que se entrecruzam na obra e atingem seu ápice a partir do momento em que a narradora-autora passa a dialogar diretamente com a protagonista. Em um primeiro momento, esse diálogo ocorre via sonho forma recorrente de Bojunga nessa trilogia de referir-se a seu processo de citação ${ }^{266}{ }_{-}$, o que já adentra o campo do imaginário. Por fim, o universo onírico já não está mais presente e ambas as vozes, a da narradora-autora e a de sua personagem, dialogam, tornando o universo do imaginário ainda mais intenso:

- Você não tá resolvida, vê se entende!

- Mas por que que eu não posso ser assim mesmo?

- Assim mesmo o quê?

- Assim: não resolvida feito você diz (...) já chega o tempo que eu fiquei numa gaveta; já chega o tempo que eu fiquei na tua cabeça: tudo tão fechado, tão cheio de complicação. Eu quero ir lá pra fora.

E hoje ela foi.

FIM

Rio, abril de 1991.

Sobre esse processo de busca que resulta em inconclusão, mencionar-se-á o que afirma o Dicionário de Teatro sobre a Imagem da Recepção da Peça no Metateatro:

\footnotetext{
${ }^{266}$ MENDES, Maria dos Prazeres Santos. Monteiro Lobato, Clarice Lispector, Lygia Bojunga Nunes: o estético em diálogo na literatura infanto-juvenil. 1994. 265 f. Tese (Doutorado em Comunicação e Semiótica) - Pontifícia Universidade Católica de São Paulo. 1994, p.178.
} 
De modo mais geral, pode-se analisar toda peça de acordo com a atitude de seu autor para com a linguagem e sua própria produção: esta atitude não deixa de transparecer na peça, e, às vezes, o autor é tão consciente desta problemática que a tematiza até fazer dela um dos principais motores de sua escritura e estruturar sua peça em função dessa tensão metacrítica e metateatral. ${ }^{267}$

Dessa maneira, Fazendo Ana Paz apresenta o recurso do Metateatro metacrítico, já que se acompanha o imenso trabalho que a escritora tem em elaborar a personagem e sua narrativa. Bojunga chega a criar diferentes tipos de pais para Ana Paz, para verificar qual se enquadraria melhor a ela. Entretanto, o final da narrativa é a metacrítica: todo o esforço que já não vinha tendo êxito já era um indício de que o desfecho era a autocrítica, o caminho inverso da perfeição que se almejava.

Para além dessa análise, é importante mencionar, novamente, o início dessa obra em que a autora retoma o seu gosto pela leitura - uma maneira de retomar a primeira obra da trilogia, que retratava bastante o amor dela não apenas pela escrita, mas sobretudo pela leitura - e o relaciona à sua vontade de escrever um livro de viagens, que ocorrera no momento em que surgiu a personagem Raquel, de A bolsa amarela. A narradora-autora, antes mesmo de se pronunciar sobre Ana Paz, conta:

Eu nunca tinha vivido a experiência de uma personagem me pegar tão desprevenida;
eu não tinha nem pensado que a gente podia parir personagem assim. A Raquel
entrou no meu estúdio feito um furacão, explodiu no caderno onde eu ia escrever o
meu livro de viagens, dizendo que tinha dez anos, que tinha um amigo inventado
chamado André e ela se correspondia com ele, e que tinha essas tais vontades
fortíssimas que ela precisava esconder depressa, depressa, DEPRESSA!
A urgência da Raquel me arrastou. Comecei a procurar depressa um lugar pra ela
esconder as tais vontades.

O termo "viagens" a que a autora se refere no início da obra é uma viagem pelo papel, pela escrita, viagem essa que começou com Raquel escrevendo um bilhete para André. Este era uma das personagens inventadas pela protagonista de $A$ bolsa amarela, visto que a menina queria ser escritora. O processo pelo qual a narrativa de Raquel se constrói - a partir dos diálogos dela com suas personagens - é muito similar ao que Bojunga utiliza para construir Fazendo Ana Paz. "Similar" porque o diálogo direto com a narradora ainda acontece pouco em comparação a obras posteriores, em que a autora se utiliza da mesma técnica.

\subsubsection{Teatro Dentro do Teatro: espelhamento em Paisagem}

\footnotetext{
${ }^{267}$ PAVIS, Patrice. Dicionário de teatro. São Paulo: Perspectiva, 2015, p.240 e 241.

${ }^{268}$ BOJUNGA, Lygia. Fazendo Ana Paz. Rio de Janeiro: Casa Lygia Bojunga, 2013, p.36.
} 
Essa obra encerra a trilogia da autora, iniciada com o projeto As Mambembadas. Na sequência destas, a autora teve a necessidade de escrever uma obra que desse continuidade ao que ela já havia começado, em Livro- um encontro, sobre o ato da escrita. Já que essa primeira obra a priori era sobre leitura e, consequentemente, livros, ela sendo uma escritora, teria de abordar também a relação entre livro e escrita. Assim surgiu Fazendo Ana Paz. Não satisfeita, a autora precisou de uma terceira obra, Paisagem, em que unisse os dois processos - leitura e escrita, o que fez dessa trilogia um projeto:

\begin{abstract}
Sou de opinião que, quando um leitor mergulha no livro que um escritor escreveu, ele está enveredando por um território sem fronteiras; nunca sabe direito até onde está indo atrás da própria imaginação, ou em que ponto começou a seguir a imaginação do escritor. Foi pensando nisso que - numa das paradas que eu dei no meu percurso com a Ana Paz - eu comecei a trabalhar um personagem chamado Lourenço.

Assim que me envolvi com o Lourenço, eu me dei conta de que o símbolo das duas metades da laranja não era o que eu estava buscando; o que eu queria pra fazer a minha fala de livro ficar mais redonda eram três pedaços da laranja; se no primeiro eu tinha falado da leitura e no segundo, da escrita, agora eu queria, nessa terceira parte, misturar uma com a outra. Foi dessa mistura que saiu Paisagem, e o caminho tão comprido que eu acabei andando resultou numa pequena trilogia. ${ }^{269}$
\end{abstract}

Paisagem é uma das obras mais complexas de Lygia Bojunga em virtude do nível de metalinguagem que a autora estabelece. A partir do momento em que suas personagens não foram completamente criadas no início da obra e que elas são coautoras da narrativa principal - ou seja, as personagens conhecem a autora e esta se transforma em personagem também -, a complexidade está dada. Assim sendo, quanto mais a Autora (grafada em maiúscula quando for referência de personagem da obra) conhece uma personagem, mais a narrativa central avança. Esta (a primeira trama) também se desenvolve por meio da intersecção de outras que surgem:

A Autora (não tem nome) recebe cartas de seu leitor - Lourenço - dizendo das afinidades que os unem (trama 1). Em uma dessas cartas, Lourenço relata um sonho que teria tido com uma paisagem: a mesma paisagem incluída em um conto da Autora, ainda por publicar, guardado em sua gaveta, só de conhecimento dela! (inicia-se aqui o suspense e a ilogicidade do fantástico com o consequente estranhamentoda Autora. A partir daí leremos a mesma cena no relato de Lourenço (via carta), trama 2; o relato da Autora que relê seu texto à busca das semelhanças notificando-nos do enredo (trama 3). Trata-se da história de um casal que tem um encontro nessa paisagem. Os antecedentes desse encontro: o Homem encontra a Mulher no metrô, apaixonam-se, mas ela some. Reencontram-se em um teatro, onde ela, após passar estranhamente da plateia ao palco, desaparece, não sem antes entregar-lhe um bilhete com um endereço. Ao chegar lá, o Homem abre a porta e defronta-se com a paisagem. Seu estranhamento, medo, suspense, nos são narrados pela Autora. Esta trama 3, voltará intercalada às cartas de Lourenço, narrador também de eventos da trama 4, que envolve sua namorada Renata, seu pai João e a

${ }_{98}^{269}$ BOJUNGA, Lygia. Livro - um encontro. 6. ed. 2. imp. Rio de Janeiro: Casa Lygia Bojunga, 2007 , p.97 e 98. 
irmã de Renata, a Menina-do-Lado, assim chamada por ser vizinha de Lourenço. Ela é que havia desenhado a paisagem em uma cartolina, que, ao ser vista por Lourenço, propicia o sonho. Este desenho, por sua vez, é mostrado pela menina à Autora, que em contínuo estranhamento, procura uma explicação, voltando ao seu texto e elucidando agora a continuação e possível desfecho da trama 3. ${ }^{270}$

Percebe-se que todas essas tramas têm em comum a paisagem, à qual o título da obra se refere. Nota-se também que tanto a Autora quanto Lourenço e a Menina do Lado assumem as mesmas funções: leitores, escritores e personagens. ${ }^{271}$ É dessa maneira que Bojunga consegue unir a escrita - "a Autora busca o confronto de visões e vozes, a questão da autoria, portanto busca o sujeito do narrar" 272 - e a leitura - "o leitor busca os desdobramentos desse narrar" 273 .

Tendo em vista o nível de complexidade metalinguístico dessa obra, passa-se à análise de seus recursos metateatrais. Assim como Fazendo Ana Paz, Paisagem não é um texto com estruturas de texto de teatro, como é Intramuros, por exemplo. Por isso, um dos principais recursos do Metateatro a ser aplicado é o rompimento "palco/plateia" que demonstra a interação entre ator e público. Em literatura, o equivalente a isso seriam todos os recursos que levassem à ilusão de rompimento "livro/leitor".

Um desses recursos literários que permitem essa ilusão em Paisagem é a escolha por um narrador-autor insciente aliado a personagens que não tenham consciência dramática, diferentemente de Ana Paz ao final de Fazendo Ana Paz.

No começo de Paisagem ("Foi no ano passado que um tal de Lourenço me escreveu..." ${ }^{274}$ ), o leitor também é insciente a respeito de Lourenço, pois não se sabe se este seria uma personagem ou, talvez, um acontecimento biográfico a partir do qual se desenvolveria a ficção. Porém, a insciência do narrador-autor é bem construída, pois demonstra não ter informações sobre Lourenço:

O Lourenço era magro? era gordo? era alto? não era?

O Lourenço usava óculos? só pra ler?

Que idade o Lourenço tinha?

Se o telefone não respondia, é porque a família tinha se mudado? o João também? E pronto! em vez de pensar na Mulher e no Homem do meu conto, lá ficava eu outra

\footnotetext{
${ }^{270}$ MENDES, Maria dos Prazeres Santos. Monteiro Lobato, Clarice Lispector, Lygia Bojunga Nunes: o estético em diálogo na literatura infanto-juvenil. 1994. 265 f. Tese (Doutorado em Comunicação e Semiótica) - Pontifícia Universidade Católica de São Paulo, p. 210 e 211.

${ }^{271}$ Ibid., p.226.

${ }^{272}$ Ibid., p.226.

${ }^{273}$ Ibid., p.226.

${ }^{274}$ BOJUNGA, Lygia. Paisagem. 7.ed. Rio de Janeiro: Casa Lygia Bojunga, 2013, p. 7.
} 
vez pensando no Lourenço: como, por que, de que jeito ele tinha sonhado com minha escrita. ${ }^{275}$

Além disso, a narradora-Autora também descreve o recebimento das cartas de Lourenço de modo a torná-las realistas, apesar de levantar uma suspeita sobre essas cartas serem parte do processo de criação literária:

Larguei a carta; eu estava perplexa.

(...) Examinei o papel, o envelope verde e amarelo em volta, o selo escrito Brasil, eu estava achando difícil de acreditar que a carta não era filha da minha imaginação. ${ }^{276}$

É interessante lembrar, nesse momento, que a personagem citada no começo de Fazendo Ana Paz é justamente Raquel, a menina que quer ser escritora e troca cartas com sua própria personagem, a qual ela acreditava que existia.

No início da trama 1 de Paisagem, a insciência da narradora-Autora leva a um contexto de inversão de papéis: a Autora é leitora das cartas de um de seus leitores, que passa a ser quem lhe escreve:

Sou teu Leitor. Estou escrevendo Leitor com letra maiúscula de propósito: acho que ser leitor é uma ocupação maior, e acho também que se um Leitor se liga numa escrita do jeito que eu me liguei nos teus livros é porque existe uma coisa chamada afinidade, é ou não é? ${ }^{277}$

Como a leitura e a escrita são assuntos predominantes, não apenas no começo da narrativa central, mas também em vários outros momentos, há a discussão sobre o conceito de Literatura, na visão da personagem Lourenço:

(...) essa coisa de escritor criar um personagem e fazer a gente acreditar nele feito coisa que toda vida a gente conheceu o cara, ou a cara. Literatura é fazer esse personagem inventado virar um espelho pra gente, é fazer a gente ficar puto da vida se o personagem faz um troço que a gente acha besteira, mas em compensação é fazer a gente entrar numa boa se ele faz um troço que a gente também quer fazer, Literatura é o jeito que um escritor descobre pra passar isso pra gente dum jeito que é só dele, e que quando um dia a gente afina com o jeito dum escritor inventar, com o jeito que é o jeito dele escrever, nesse dia a gente vira Leitor dele e quer ler tudinho que o cara ou a cara escreveu, mas quando eu digo a gente eu tô falando de Leitor feito eu, Leitor de letra maiúscula (...) ${ }^{278}$

As cartas de Lourenço aliadas à insciência da narradora-Autora permitem, dentre outras possibilidades, uma leitura realista; porém, que rompe com os limites "livro/leitor", já

\footnotetext{
${ }^{275}$ BOJUNGA, Lygia. Paisagem. 7.ed. Rio de Janeiro: Casa Lygia Bojunga, 2013, p.28.

${ }^{276}$ Ibid., p. 12 e 13.

${ }^{277}$ Ibid., p.8.

${ }^{278}$ Ibid., p.56.
} 
que este é transformado em personagem de uma obra da autora ao mesmo tempo em que, esta se coloca em papel de personagem, sem ambos terem consciência disso na maior parte da obra.

Pode-se dizer, portanto, que a trama 1, a partir do gênero textual carta, auxilia a construir uma narrativa de caráter realista, por meio do narrador insciente e da troca de papéis entre quem lê e quem escreve:

Figura 24 - Trama 1de Paisagem

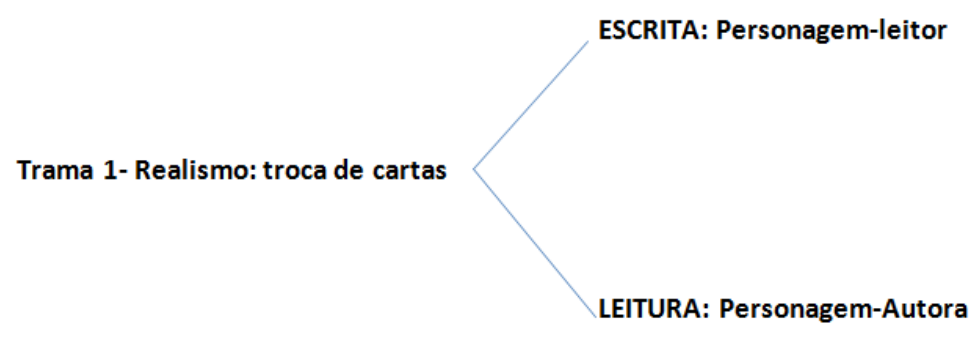

O rompimento "livro/leitor" não ocorre apenas por intermédio do narrador insciente, mas também da troca de narradores que ocorre, visto que as personagens, que são leitoras da Autora, podem narrar suas explicações para a paisagem: na trama 2 é o Lourenço, na trama 4 é a Menina que Mora do Lado. Na trama 2, Lourenço, por meio do sonho, que remete ao universo do fantástico, é um narrador-personagem, pois descreve a paisagem que viu em seu sonho:

(...) o que eu queria te contar é que esta noite eu sonhei com você, quer dizer, eu sonhei com uma paisagem, você não aparecia no sonho, mas o tempo todo eu tinha certeza que tudo que eu estava sonhando tinha sido escrito por você; era uma paisagem assim: tinha um campo de flor, flor branca, amarela, vermelha e azul, mas tudo que é flor de repente parava e começava um areão que ia indo e ia indo e acabava lá no mar; tinha muita pedra nesse areão, às vezes era pedra sozinha, às vezes era um monte de pedra, às vezes elas tinham cara de ruína de antigamente; olhei pro lado e vi um pedaço duma casa feito da mesma pedra que tinha na areia, fiquei pensando se a casa estava sendo construída ou se ela era tão velha que já tinha perdido um pedaço; tinha sol no campo de flor, mas em compensação no areão não tinha, e no mar o céu era cinzento, tinha um barco no mar, e eu me lembro que eu fiquei olhando pra ele e pensando pra onde é que esse barco tá indo? ou será que ele tá voltando? de repente uma coisa chamou a minha atenção lá na areia: tudo que é pedra tinha a mesma forma quadrada, mas uma delas era diferente, parecia um ovo enorme, e me deu uma vontade danada de ir lá examinar melhor, mas eu não sabia onde é que eu estava, às vezes eu pensava de onde é que eu tô vendo essa paisagem? é do campo de flor? é de dentro da casa? é do mar? eu só sabia que eu estava ali 
vendo uma paisagem que quanto mais eu olhava mais eu tinha certeza que ela tinha sido escrita por você. ${ }^{279}$

Lourenço explica que teria sonhado com a paisagem, pois lia muito as obras da Autora, por isso teria sonhado com o mesmo estilo da literatura dela. Novamente, tem-se a relação entre leitura e escrita, porém via maravilhoso:

Figura 25 - Trama 2 de Paisagem

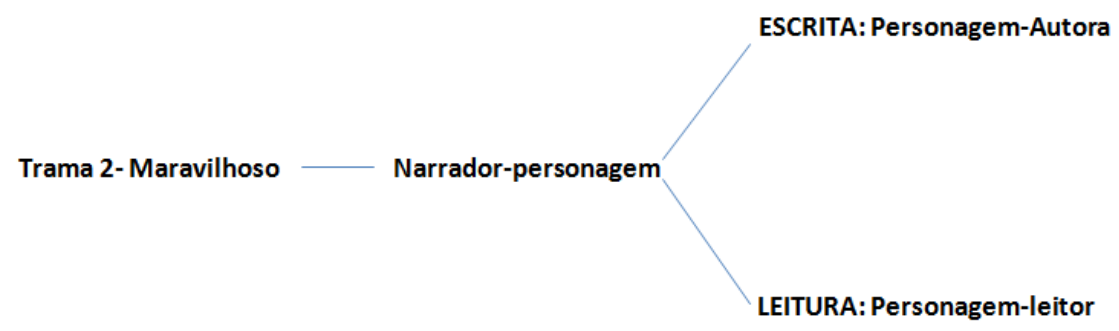

$\mathrm{Na}$ trama 4, a Menina que Mora do Lado é a narradora-personagem e, também, essa narrativa, que explica o modo como o desenho da paisagem foi feito, está relacionada à escrita e à leitura. A Autora escreveu o conto, que foi lido e levado pelo vento até a narradorapersonagem. Esta leu o texto e o transformou em desenho a pedido dele mesmo. A explicação da narradora-personagem se faz via universo do maravilhoso:

Figura 26- Trama 4 de Paisagem

ESCRITA: Personagem-Autora

Trama 4- Maravilhoso: narrativa-desenho

LEITURA: Personagem-leitora

${ }^{279}$ BOJUNGA, Lygia. Paisagem. 7.ed. Rio de Janeiro: Casa Lygia Bojunga, 2013, p.12 e 13. 
Já a trama 3, que é fundamental para a intersecção de todas as tramas, apresenta um recurso metateatral, oriundo do Teatro Dentro do Teatro, que é o espelhamento, o qual será explicado após a retomada do início da trama 3, em que a narradora, que é a persongemAutora, narra parte de um de seus contos ainda não terminados. Nesse momento, há referência à possibilidade de esse conto ser uma peça teatral, visto que a Mulher, personagem do conto, some porque atravessou um cenário de teatro:

Um dia ela vai ao teatro. Começa a ficar agitado. Tira o olho do palco e vai virando a cabeça. Encontra o olhar da Mulher. E quem diz que o olho dos dois vai querer se largar? Mas quando a plateia se acende pro intervalo, a Mulher se levanta, sobe os degraus que separam a plateia do palco, entra no cenário (é um quarto de dormir), abre uma porta, se vira, olha mais um pouco pro Homem e depois sai, fechando a porta.

Quando o segundo ato começa e a Mulher não volta pro lugar dela na plateia, o Homem fica na maior aflição, mas então ela fazia parte da peça? ia entrar em cena a qualquer momento? ${ }^{280}$

Claramente não há vestígios da trama 1, imagina-se, portanto um teatro. Porém, a narradora personagem-Autora quebra essa ilusão e leva o leitor para outra trama: "e eu fui folheando toda essa obsessão até chegar na página que eu queria encontrar" ${ }^{281}$. A partir disso, há mudança gráfica para que se saiba que a narradora irá de fato ler o conto, não apenas narrálo:

Figura 27 - Conto Paisagem (Trama 3)

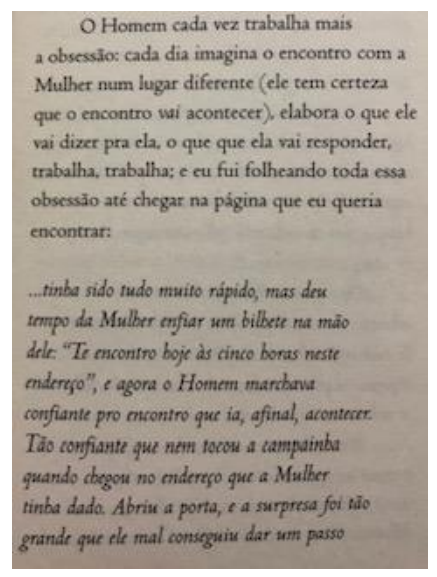

Fonte: Lygia Bojunga

$\mathrm{Na}$ trama 3, a partir da leitura do gênero conto, a autora conseguiu fazer a personagem-Autora ser narradora, leitora e escritora:

\footnotetext{
${ }^{280}$ BOJUNGA, Lygia. Paisagem. 7.ed. Rio de Janeiro: Casa Lygia Bojunga, 2013, p. 14 e 15.

${ }^{281}$ Ibid., p. 15.
} 
Figura 28 - Trama 3 de Paisagem

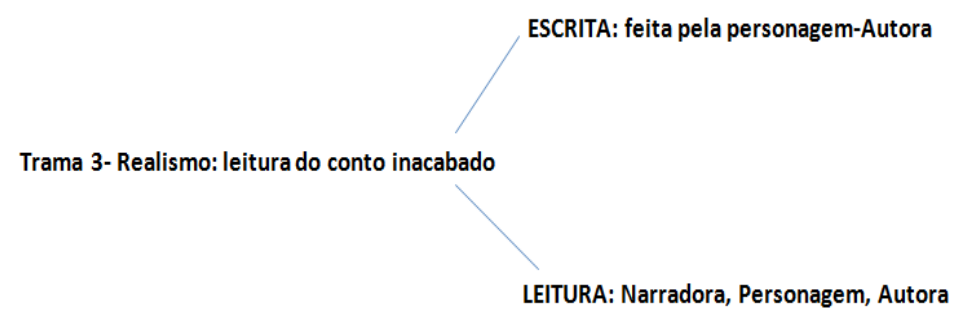

A trama 3 desenvolve-se e resolve-se o mistério da trama 4 por a personagem-Autora ter incluído a Menina que Mora ao Lado na trama 3. A personagem torna-se filha da Mulher e do Homem do conto. Por esse motivo, ela desaparece da trama 1. João é uma personagem que também desaparece da trama 1 na medida em que a personagem-Autora resolve dar um novo final para Paisagem e o coloca nessa nova cena. Na trama 1, portanto, sobra Lourenço, que reclama do desaparecimento de todos. O final da trama 1, que desde o início é o diálogo entre personagem-Autora e personagem-leitor, é ao mesmo tempo o final da trama 3 e a explicação para a trama 2: a personagem-Autora e a personagem-leitor vão parar dentro da paisagem. Todos esse processo literário é similar a um recurso do Metateatro, mais especificamente do Teatro Dentro do Teatro, que é o espelhamento:

O jogo de espelhos é um procedimento dramatúrgico e cênico que pode se manifestar a partir de vários procedimentos, como a autorreferência, personagens baseados no próprio autor, atores que se identificam com os próprios personagens, peça interior que reflete a peça exterior, o recurso cenográfico do dispositivo cênico que reflete a própria sala de espetáculos, entre outros. ${ }^{282}$

É perceptível que nessa obra há autorreferência, personagem baseada na autora - as referências à cidade do Rio de Janeiro, por exemplo - e, sobretudo, há uma narrativa que reflete outra exterior a ela e não apenas isso, pois, como em um jogo de espelhos, a imagem refletida em um espelho não é idêntica à original, o que leva à modificação de todas as imagens refletidas também nos demais espelhos. Essa modificação é, na verdade, a revelação de uma realidade velada:

Conforme Tadeusz Kowzan, 'O espelho interpreta plenamente seu papel de detentor de uma realidade oculta quando ele reflete [...] um mundo que se situa fora do espaço representado no próprio quadro'. Dessa forma, se se considera o teatro como espelho do mundo, no teatro dentro do teatro (que é um segundo espelho) revela-se 'a face oculta de personagens e acontecimentos'. O metateatro é, portanto, um

\footnotetext{
${ }^{282}$ SILVA, Igor de Almeida. A vertigem das máscaras: metateatralidade na Compahia Teatro de Seraphim,
} 2014. 194 f. Tese (Doutorado em Artes) - Universidade de São Paulo, São Paulo, p.27. 
segundo ou terceiro espelho, que reflete e, por vezes, deforma a imagem refletida. ${ }^{283}$ 284

Essa revelação "fora do quadro", no caso de Paisagem, pode ser lida literalmente, visto que o desfecho e a explicação de todas as tramas que estavam fora da paisagem final são revelados a partir da última cena, sendo esta o espelhamento que remete às demais tramas, desvelando a origem de todas as personagens.

Outro recurso do Metateatro que é encontrado nessa obra é a relação dela com a ideia de explicar a construção de um cenário: a paisagem. Se na primeira obra do projeto de Lygia o título era um objeto (livro), no segundo o título estava voltado para a ação de construir uma personagem (Ana Paz), este terceiro é o espaço (Paisagem) ou o cenário, como é afirmado na própria obra, com referência explícita ao teatro:

- Olha a Renata tem umas coisas que me deixam louco, isso por exemplo, lá tô eu
parafusando o nosso mistério e ela vem e me diz com a cara mais limpa do mundo
que não tem mistério nenhum, ah, não? eu perguntei, não, você e essa mulher (ela
não é tua leitora, viu, por isso que ela te chama de essa mulher), você e essa mulher
frequentaram o mesmo cenário, (a Renata agora chama tudo de cenário, acho que é
porque ela tá fazendo um curso de teatro), mas Renata, esse cenário não existe, é
uma paisagem inventada pr'uma história que ainda está sendo escrita, que eu não li
nem nada, como é que eu posso ter frequentado um cenário que só existe na cabeça
duma mulher que eu nunca vi? ${ }^{285}$

Essa ideia de cenário, que é um termo material típico do teatro, aliado à mente, à imaginação, que é imaterial, reforçam a tese de que se trata de um espaço teatralizado, porém de modo peculiar, que pode ser explicado pelo Metateatro. Este tem uma relação diferente com o espaço físico "a tragédia metateatralizada transforma o espaço físico em metafísico" 286, o que é essencial para a compreensão dessa obra, já que Paisagem também é um espaço, que se narra, se sonha, se lê, se escreve, se desenha com descrições físicas; no entanto; sempre se trata de um espaço metafísico. Nesse sentido, há a reflexão sobre o processo de criação, que partiria de uma descrição física já vista, lida ou vivida:

Comecei a examinar uma possibilidade atrás da outra. Quem sabe eu já tinha visto essa paisagem num lugar qualquer? uma gravura... uma pintura.... Uma pintura que

\footnotetext{
283 Apud SILVA, Igor de Almeida. A vertigem das máscaras: metateatralidade na Compahia Teatro de Seraphim, 2014. Tese de Doutorado apresentada à Escola de Comunicação e Artes da Universidade de São Paulo, p.27.

${ }^{284}$ Nota do autor: KOWZAN, Tadeusz. Théâtre miroir: metathéâtre de l'Antiquité au XXIe siècle. Op. Cita, p.10. "Le miroir joüe pleinement son rôle de détecteur d'une réalité cachée quand'il réfléchit [...] um mond qui se situe em dehors de l'espace reprérenté dans le tableau même." [Tradução nossa].

${ }^{285}$ BOJUNGA, Lygia. Paisagem. 7.ed. Rio de Janeiro: Casa Lygia Bojunga, 2013, p.46.

$286 \mathrm{Na}$ tessitura da intriga, estudos sobre as interpretações das narrativas. Disponível em: http://tessituradaintriga.blogspot.com/2010/04/fundamentos-do-metateatro.html. Aceesso em 01 ago.2019.
} 
o Lourenço também tinha visto?... Quem sabe eu nunca mais tinha me lembrado dessa pintura, mas a lembrança dela tinha ficado lá no meu 'sótão' e agora se intrometia na minha escrita...? Ou então, vai ver, a paisagem era parte de um livro que eu tinha lido? (Ou de um filme que eu tinha visto?) Um livro da minha infância? da minha adolescência? Um livro que o Lourenço tinha lido também... e a paisagem tinha feito uma impressão funda nele... e agora ele sonhava com ela... será? Nesse caso, o que eu pensava que era minha invenção não passava de uma lembrança que tinha dormido e que agora acordava? ${ }^{287}$

\subsubsection{Intramuros: a trilogia literária inversa e a autorreferência}

Esta é uma obra, que, segundo citação apresentada na contracapa do livro, está relacionada a um projeto de vida:

Creio que Intramuros pode ser catalogado como romance, mas, pra mim, tem mais a ver com um depoimento literário, digamos assim - um despretencioso relato de como a gente, se perdendo, vai se descobrindo no esforço de escrever um livro. Não é uma obra voltada para leitores mirins, e sim para quem se interessa pelo fazer literário e pelo cumprimento de um projeto de vida. ${ }^{288}$

Além da afirmação sobre o cumprimentoo desse projeto, há a menção não apenas ao processo de criação literária, mas também ao público a que a obra é voltada. Por esses motivos, a metáfora da "estrada" a que a autora se refere no texto "Caminhos", que explica sua trilogia sobre leitura, escrita e ambas, é retomada nesse momento para propor a análise de que Intramuros, por meio de recursos do teatro e do metateatro, percorre o caminho inverso da trilogia:

Paisagem: Leitura (leitor) e escrita (autora)

Fazendo Ana Paz: Escrita

Livro - um encontro: Leitura e escrita (da autora)

Nessa obra, a autora resolve o problema que havia apontado no final de Livro - um encontro:

(...) ainda estou olhando pros encontros com a escrita que eu contei aqui, pensando se eles misturaram bem com os meus casos de amor...

Uma hora eu acho que sim.

\footnotetext{
${ }^{287}$ BOJUNGA, Lygia. Paisagem. 7.ed. Rio de Janeiro: Casa Lygia Bojunga, 2013, p. 19.

${ }^{288}$ BOJUNGA, Lygia. Intramuros. 1. ed. . Rio de Janeiro: Casa Lygia Bojunga, 2016.
} 
Outra hora eu comparo um com o outro e fico achando que o 'eu te lendo' nasceu com cara de pra ser dito e o 'eu te escrevendo' pra ser lido. ${ }^{289}$

O "eu te lendo" é a parte da obra que foi representada (falada) pela autora no palco, ao contrário da parte "eu te escrevendo" (apenas lida pelo leitor, sem o intermédio do palco). Há, pelo menos, duas maneiras de misturar ambos em Intramuros:

1) A transformação do Pra você que me lê em obra. Esta é, justamente, a parte das obras da autora em que não só ela conta alguma informação sobre o processo de escrita da obra como também é o espaço em que dialoga com o seu leitor;

2) A transformação de grande parte da obra em texto de peça de teatro, pois, assim, o que era apenas para ser lido está sendo representado (falado) em um palco. Desse modo, as personagens são colocadas no palco para o leitor ler as suas falas.

Sobre a primeira maneira, trata-se de um narrador que é personagem e o próprio autor, visto que o final do Pra você que me lê que é também Intramuros é assinado pela autora. Esta, por meio do Pra você que me lê de Intramuros, adota a metalinguagem, ao explicá-lo: "eu te contava um fato qualquer que tinha influenciado a feitura do livro, ou uma outra passagem da minha vida relacionada, em geral, ao trabalho que realizo." ${ }^{290}$ Além disso, ela assume a culpa que sente na sua relação com as personagens:

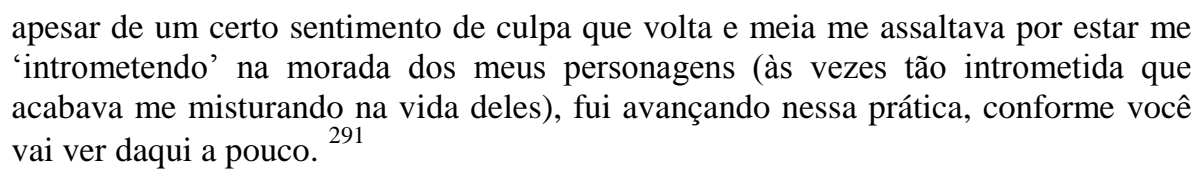
apesar de um certo sentimento de culpa que volta e meia me assaltava por estar me 'intrometendo' na morada dos meus personagens (às vezes tão intrometida que vai ver daqui a pouco. ${ }^{291}$

Esse assunto da relação da autora com as personagens é retomado ao longo da obra e é de extrema importância na compreensão não apenas da obra Intramuros, mas também do projeto de arte da autora, o qual se mistura com a sua vida.

O início de Intramuros também elenca vários afazeres do cotidiano da autora como forma despretenciosa de informar o leitor que esse Pra você que me lê seria diferente, visto que a obra não tinha sido escrita ainda:

... nunca fui de escrever um livro atrás do outro, já te contei em outros papos que escrever livro é, pra mim, um caminho tortuoso e longo; quando consigo botar o tal ponto chamado final (acabado livro nenhum nunca está), embora sendo tomada pela vontade de começar a escrever outro, a página em branco me paralisa durante um

\footnotetext{
${ }^{289}$ BOJUNGA, Lygia Livro - um encontro. 6. ed. 2. imp. Rio de Janeiro: Casa Lygia Bojunga, 2007, p.91.

${ }^{290}$ BOJUNGA, Lygia. Intramuros. 1. ed. . Rio de Janeiro: Casa Lygia Bojunga, 2016, p.8.

${ }^{291}$ Ibid., p.8.
} 
largo tempo... Botei no caderno uma borboleta azul que encontrei morta numa trilha da Boa Liga; botei uma flor que murchou e que, quando me deram, era de um vermelho que só mesmo o Goya foi capaz de reproduzir; copiei um poema do Bandeira recebido num e-mail; fiz uma porção de desenhos (como sempre malfeitos) dos espaços onde passariam a acontecer alguns dos projetos da Fundação; anotei telefones, endereços, nomes que me ocorreram pra futuros personagens; recheei três ou quatro páginas com diálogos que iriam acontecer numa peça de teatro que eu iria escrever; coisas assim...

E aí, um dia, aconteceu essa coisa, pra mim muito estranha, que eu queria te contar. De repente, com absoluta convicção, escrevi bem grande, no meio de uma página em branco, o título do meu novo livro:

\section{N T R A M U R O S}

Estranha, sim: nunca tinha me ocorrido dar nome a um livro que não só eu estava escrevendo, como não tinha a menor ideia de que livro ele ia ser. ${ }^{292}$

Sobre a segunda maneira de relacionar leitura e escrita, pode-se afirmar que a opção por escrever em letras maiúsculas o título da obra - o que também acontece com o nome da protagonista, Nicolina - remete ao processo de escrita de uma peça teatral: o nome da peça e, na sequência, o nome das personagens já em diálogo. Ademais, ao longo da obra, há o uso de didascálias centralizadas - tal como aparecem centralizados os nomes próprios mencionados que são intercaladas às falas das personagens. Essas rubricas sempre indicam a intensidade ou duração do silêncio entre uma fala e outra ou a referência ao riso ou outro gesto, sobretudo de Nicolina.

Como a obra, inicialmente, versa bastante sobre o processo de criação literária, a personagem Nicolina, além de ser a primeira a aparecer para o leitor, é introduzida teatralmente pela autora, que utiliza didascálias também para mostrar a este as referências espaciais dos bastidores do teatro.

Ah! Se este nosso espaço [Pra você que me lê] fosse um palco, eu não teria que ficar tão cheia de dedos pra te fazer esta apresentação. Bastaria eu virar um pouquinho a cabeça e fazer um gesto e dizer, esta é a Nicolina. E, pronto! Ela entrava em cena e, num segundo, se revelava pra você - na aparência, na expressão do rosto, no jeito de andar, de olhar, de sorrir. (...)

Então, já que eu estava pensando em termos de teatro, resolvi dar uma deixa pra Nicolina entrar e se apresentar. (...)

- Olha, esta é a Nicolina. Entra, meu bem, não fica aí parada na porta feito coisa que você não quer se mostrar; que que é isso gente! Este espaço também é teu. Quer dizer, é muito mais teu do que meu, tanto que é você quem vai contar a tua história, é ou não é?

- Não sei se eu tô a fim.

- Ué!... você não me disse que estava? Que ia ser bom ouvir a tua própria voz relembrando os fatos? Não disse que isso ia te ajudar a enfrentar melhor essa visita que você está esperando e que tá te deixando tão nervosa?...

- Eu não tô nervosa!

(...)

${ }^{292}$ BOJUNGA, Lygia. Intramuros. 1. ed. . Rio de Janeiro: Casa Lygia Bojunga, 2016, p.9 e 10. 
- Bom... então vocês vão me dar licença. Outra hora eu volto. Tchau-tchau. - Desculpa. Desculpa, viu? Desde pequeniníssima que eu sofro de acesso de riso (...)

Na despedida da autora, é inserida uma nota de rodapé (a didascália do teatro) que antecede a fala de Nicolina e, portanto, esclarece sobre o riso: "É só eu sair que a Nicolina começa a rir. Sem parar. Vou ficando aflita. Devo intervir? Me aproximo da porta. Não sei se entro ou não entro. Resolvo esperar. Afinal, riso para. Vou indo embora." ${ }^{294}$ Nota-se, por meio desse trecho, que a autora também estava sobre o palco, o que leva a uma fusão: narradora literária e narradora de teatro. A nota de rodapé/didascália, além da função de esclarecer um gesto - outro recurso teatral -, faz um comentário metateatral: o narrador da peça de teatro deve ou não intervir?

Assim começam os extensos monólogos, gênero teatral esse que permite à personagem falar de si mesma e conversar com o espectador/leitor, como é perceptível desde o pedido de desculpas de Nicolina ao público/leitores. Esse recurso é metateatral, porque

o personagem tem ciência de que está em um teatro representando um papel, e dada esta "consciência dramática", ele passa a desconsiderar a quarta parede, podendo se referir diretamente ao público que o assiste. ${ }^{295}$

Nicolina sabe que está representando um papel, visto que essa não é, de fato, a primeira cena que a autora escreveu ou "concebeu" da personagem:

Você se lembra daquele nosso primeiro papo, quando eu te apresentei a Nicolina? Ou melhor, quando a Nicolina se apresentou a você pra historiar a vida dela? Você deve ter notado que ela estava bastante agitada, não é? Naquela ocasião, já tinha acontecido a cena violenta com a Nina, e o Vinícius tinha ido embora de casa levando a filha pra ficar aos cuidados da Rosário. ${ }^{296}$

Assim sendo, considerando que no começo da obra a autora afirma que "aconteceu essa coisa, pra mim muito estranha, que eu queria te contar", o assunto da obra não é apenas esse processo de criação literária, visto que ele mesmo, como descrito inicialmente, já fora elaborado. Há outra novidade que a autora vai contar, mas por meio da qual só se deu conta durante o processo de escrita, escrita essa muito baseada na autoficção. Exemplos de autoficção na obra são: a autora remeter aos lugares onde se reveza para morar (Rio e

\footnotetext{
${ }^{293}$ BOJUNGA, Lygia. Intramuros. 1. ed. . Rio de Janeiro: Casa Lygia Bojunga, 2016, p.14 e 15. ${ }^{294}$ Ibid., p.15.

${ }^{295}$ NEVES, Vanderson de Souza; PASCOLATI, Sonia Aparecida Vido. O metateatro na obra o Rei da vela de Oswald de Andrade: criação de uma gramática de recursos metateatrais, p.4. Disponível em:http://www.uel.br/eventos/sepech/sepech08/arqtxt/resumos-anais/VandersonSNeves.pdf. Acesso em: 07 jul. 2019.

${ }^{296}$ BOJUNGA, Lygia. Intramuros. 1. ed. . Rio de Janeiro: Casa Lygia Bojunga, 2016, p.149.
} 
Londres) e às capas decoradas de cadernos que recebe de leitores que conhecem seus gostos. Partindo disso, pode-se afirmar que Bojunga utiliza a autoficção para construir o Pra você que me lê, que, ao mesmo tempo, é a obra Intramuros. Esse processo auxilia a ligação entre escrita e leitura, ao se incluir o leitor que já conhece a autora; porém, a "autoficção é um jogo com o leitor. O autobiógrafo quer contar a verdade enquanto o escritor autoficcional conta alguma, mas não toda" ${ }^{297}$ Nesse sentido, há ainda alguma informação acerca da autora sobre a qual o leitor não sabe, o que será revelado somente ao final da obra, já como um depoimento biográfico.

Além da relação leitura-escrita, Bojunga retrata nessa obra a preocupação com o fazer literário, importância que é dada na segunda obra da trilogia: "Fazendo Ana Paz". A escrita aí é essencial, pois ele expressa a busca por maneiras de escrever a personagem, que, ao mesmo tempo, é a busca da própria escritura da autora: "enquanto a Autora não tecer sua viagem, a da Ana Paz não se processará, e vice-versa. São dois processos que se intercalam e que se interdependem" 298 . Essa busca da escritura coincide com a busca do autoconhecimento, que ocorre por meio do processo de criação da casa onde as três personagens irão se descobrir enquanto uma só. Há referências, não apenas na narrativa, mas também no Pra você que me lê da obra, sobre as lembranças da casa da infância da autora, o que ajudou na criação da obra. Nesse sentido, a casa foi uma memória mediadora no processo de escrita e também da criação de Ana Paz. Assim, o passado da autora foi essencial no processo de elaboração da obra. Em Intramuros, apesar de haver referências à valorização do passado da própria autora, esse aparece como processo de impedimento da continuidade da criação literária:

Era só eu começar a pensar em você [Nicolina] que, em vez de te situar no galpão,
ou na horta do Intramuros, ou numa praia do Rio (...) eu ia pra outros cenários muito
diferentes: os meus. Não só os cenários de agora, mas sobretudo da minha infância
(...) E lá se ia a manhã todinha nesse trabalho arqueológico (...) Mas não vai agora
pensar que foi só por causa desses exercícios arqueológicos, volta e meia, eu
sumia... A razão principal é que venho dedicando grande parte das minhas horas de
trabalho a um projeto de vida que arquitetei (...) criei a casa que iria abrigar vocês
todos, isto é, uma editora - minha própria editora. Meu 'projeto arquitetônico'
previa, após a consolidação da editora, (...) a criação de uma fundação cultural cujos
projetos seriam desenvolvidos a partir das minhas próprias moradas. Essas novas
moradas passaram a dar cria, quer dizer, a se reproduzir em novos espaços, todos
inspirados nele, no Livro - espaços esses que vêm sendo trabalhados pra mais
adiante se tornarem públicos e serem aproveitados por muitos como locais de prazer,
tranquilidade, convívio com a Natureza e, por que não, não é? Reflexão de tudo que
o Livro me deu, ou melhor, de tudo que o Livro pode nos dar, uma vez que, sem o

\footnotetext{
${ }^{297}$ FIGUEIREDO, E. Autoficção feminina: a mulher nua diante do espelho. Revista Criação \& Crítica, n. 4, p. 91-102, 15 abr. 2010, p.97.

${ }^{298}$ MENDES, Maria dos Prazeres Santos. Monteiro Lobato, Clarice Lispector, Lygia Bojunga Nunes: o estético em diálogo na literatura infanto-juvenil. 1994. 265 f. Tese (Doutorado em Comunicação e Semiótica) - Pontifícia Universidade Católica de São Paulo, São Paulo, p.201.
} 
Livro, sem vocês, eu nunca poderia ter criado os espaços que eu criei (...) Sempre me pareceu que, se o meu "projeto arquitetônico" era inspirado no Livro, eu não podia me separar dele: tínhamos que percorrer todo o caminho juntos: de leitora e escritora; de escritora e editora; e de editora a instituidora de uma fundação que abarcasse os espaços que eu havia criado pela vida afora, para que, então, neles fossem desenvolvidos projetos culturais e ecológicos. Gostaria que o Livro estivesse presente sempre nesses espaços, não importa de que maneira. Quis fazer, no que ainda são minhas moradas, o casamento do Livro com a Natureza, na esperança de que pudessem servir a todos que viessem a esses espaços, não só como inspiração e nutrição emocional e/ou intelectual, mas também (sobretudo?) como alimento e prazer dos sentidos. Quanto a isso, as possibilidades são mais amplas na Boa Liga (...) 299

As horas gastas com os acontecimentos presentes e os projetos ${ }^{300}$ (futuro do seu legado enquanto autora) foram as causas maiores do impedimento da obra. Porém, ao mesmo tempo, foram esses acontecimentos somados ao convívio de anos com as personagens em construção - não apenas Nicolina - que levaram Bojunga a encontrar o significado não apenas da obra Intramuros, como também o de seu projeto de vida:

Então, Nicolina, este meu desejo profundo, inconsciente, cujo primeiro vestígio se manifestou quando, sem saber por que, eu contei pro público o nome da tua futura morada, só agora, depois desse longuíssimo convívio com vocês, se mostrou na sua inteireza: quero-e-preciso ficar 'intramuros', com tudo que enfiei dentro deles. Nos espaços dos quais me tornei guardiã.

\section{A Nicolina fica quieta durante um bom tempo}

- Por acaso a Coronela está querendo dizer que eu e o Intramuros servimos foi de metáfora?

- Não. 'Serviram' (e bota aspas neste verbo, hein, dona Nicolina) foi pra eu enxergar com clareza onde é o meu lugar. ${ }^{301}$

Nota-se que o termo intramuros não remete apenas às personagens, à ficção, mas também aos espaços físicos os quais Lygia Bojunga construiu e que são os meios pelos quais a autora manterá o seu legado cultural e social. Nesse sentido, Nicolina, por meio de sua arte, assim como Bojunga, auxilia financeiramente pessoas de baixa renda, no caso da protagonista, a ajuda é destinada à família de Garibalde e é decorrente da venda de seus bonecos e das hortaliças que a bonequeira cultiva.

Logo, Nicolina aproxima-se muito da autora, visto que é uma personagem que, desde criança, cria bonecos - uma metáfora para Lygia que cria personagens literárias, sempre

\footnotetext{
${ }^{299}$ BOJUNGA, Lygia. Intramuros. 1. ed. . Rio de Janeiro: Casa Lygia Bojunga, 2016, p.165-168.

${ }^{300}$ A Fundação Cultural Casa Lygia Bojunga apresenta sete projetos , todos relacionados aos interesses da autora - o livro, a leitura, o teatro, a contação de histórias, a natureza, o bairro de Santa Tereza e o auxílio a jovens carentes (inclusive, um dos projetos recebeu o nome de "bolsas de estudo épico", que gratifica os jovens que mais se envolvem com livros. Informações disponíveis em:
} http://www.casalygiabojunga.com.br/pt/afundacao.html. Acesso em: 01 ago.2019.

${ }^{301}$ BOJUNGA, Lygia. Op. cit., p.170 e 171. 
valorizando a arte artesã - e fica, também, "intramuros" com eles: "já movida por uma decisão: queria voltar pra lá e tratar do terreno, da casinha, do galpão; queria semear, plantar, regar; botar a mão pra fazer e inventar." 302

Nesse sentido, é interessante notar que a história de Nicolina reflete o desejo da autora de permanecer intramuros com suas personagens, o que remete ao jogo de espelhamento, típico do Teatro dentro do Teatro, sobretudo nessa obra que se passa sobre um palco: a história de Nicolina reflete a história de Lygia Bojunga.

Essa relação da autora com suas personagens, em Intramuros, acontece de maneiras diversas. Duas delas são as constantes mudanças de foco narrativo e a autorreferência.

Sobre a mudança de foco narrativo, é possível perceber que a obra se inicia e termina como Pra você que me lê, sendo início e fim claramente narrados em primeira pessoa pela própria autora da obra. Entretanto, esse narrador cede seu espaço para Nicolina falar sobre ela mesma, sobre um palco, assim diminuindo a necessidade de um representante (narrador) que o faça por ela. Nesse momento, o foco narrativo é a primeira pessoa ainda, porém é um narrador-personagem que fala sobre sua infância conturbada devido à construção de bonecos e ao riso incessante. $\mathrm{O}$ uso de primeira pessoa tanto para a narradora Nicolina quanto para a narradora Lygia, considerando que ambas estão sobre um palco, transforma o discurso de ambas em um monólogo. Esses monólogos são metateatrais, visto que as personagensnarradoras usam as cenas para explicarem a si mesmas. Na sequência, a autora retorna: "Olá! Voltei pra retomar nosso papo." ${ }^{303}$ Como há uma imagem que separa a cena da retirada de Nicolina desse retorno, não se sabe, até o momento, se a personagem-autora está apenas continuando a escrita do Pra você que me lê ou se, de fato, voltou para o palco, ou mesmo ambos. Nessa parte da obra, ela conta o processo de criação da personagem Vinícius, pai de Nina, filha de Nicolina. Quando Vinícius chega das nuvens para as quais a autora olhava, esta trava um diálogo com sua personagem, que passa a contar outra parte da história de Nicolina, sobretudo a que a relaciona ao título da obra: “(...) vou providenciar a construção de um muro bem alto cercando o terreno todo. (...) Pra me esconder do mundo e pra te fazer meu prisioneiro aqui dentro." ${ }^{304}$ Entre esse e outro diálogo que Lygia trava com Vinícius, há a volta de monólogos da autora, falando sobre seu gosto por habitações, sobre a migração Londres-Rio, assunto que é interrompido pela chegada de Vinícius por intermédio das nuvens.

\footnotetext{
${ }^{302}$ BOJUNGA, Lygia. Intramuros. 1. ed. . Rio de Janeiro: Casa Lygia Bojunga, 2016, p.161.

${ }^{303}$ Ibid., p.42.

${ }^{304}$ Ibid., p. 56.
} 
Sabe-se que ainda se está na peça de teatro pela rubrica indicando silêncio após a saída de Vinícius por meio de uma nuvem, rubrica essa que antecede a fala da autora: "Acho que eu também: agora vou te deixar. Ia te contar deste meu estúdio, o Crow's nest segundo, mas o céu está mudando de cara (...) Volto outra hora, viu?" 305 A autora intercala monólogos e diálogos com suas personagens ou permite que Nicolina se expresse em primeira pessoa, seja via palco, seja via papel: “encontrei a Nicolina instalada muito à vontade diante da minha mesa de trabalho batendo papo contigo. (...)" ${ }^{306}$ Nesse momento, os focos narrativos se invertem: a primeira pessoa que narrava um monólogo e conversava ao mesmo tempo com o leitor/público - autora - dá espaço à personagem, que mantém a estrutura de peça teatral (didascálias) ao continuar contando sobre a história dela. Nicolina para de escrever, pois acaba dormindo de cansaço ao falar tanto - o verbo utilizado pela personagem é "falar", não “escrever", por isso, novamente, retoma-se a imagem de Nicolina no palco. Há também a narradora-autora contando o processo de criação da personagem Garibalde e passa do foco narrativo de primeira pessoa para terceira, para contar sobre o encontro dessa personagem com Nicolina. No desenrolar da narrativa, Nicolina interrompe a autora para falar sobre Garibalde, o que faz o narrador de terceira pessoa voltar novamente a ser primeira pessoa para poder dialogar com Nicolina.

Toda essa intercalação de focos narrativos, aparentemente, permite a plena autonomia das personagens; porém, a autora sempre lembra o leitor que, mesmo havendo essa autonomia, quem a cria é a autora: "resolvi acabar com aquele procedimento tolo de Nicolina, que insistia no papel de subalterna, batendo calcanhar de continência para mim. Fiz ela voltar a você pra continuar contando a vida dela." ${ }^{307}$ Esse é o trecho em que a autora explica que a parte em que Nicolina é surpreendida pela autora escrevendo para o leitor foi um procedimento literário. Nesse sentido, a autora afirma que esses são recursos para estruturar a narrativa e, por consequência, a própria peça de teatro, o que é um recurso metalinguístico e metateatral.

Além da multiplicidade de focos narrativos, há a autorreferência, que é um dos recursos do Metateatro:

Ao usar recursos metateatrais como a autorreferência, a comunicação com o público e a troca de figurino no palco, a comédia recusa justamente aquilo que a tragédia

\footnotetext{
${ }^{305}$ BOJUNGA, Lygia. Intramuros. 1. ed. . Rio de Janeiro: Casa Lygia Bojunga, 2016, p. 85.

${ }^{306}$ Ibid., p. 87.

307 Ibid., p. 159 .
} 
parece buscar: o envolvimento e a ausência de distanciamento entre espetáculo e espectador. ${ }^{308}$

Embora Intramuros não se trate de uma comédia, é válida a afirmação de que a comunicação com o público - conversa de Lygia e de Nicolina com o leitor - e as autorreferências aproximam plateia e público, ou, nesse caso, leitor e obra. Bojunga, em vários momentos de Intramuros, dirige-se aos seus leitores fazendo autorreferência a outras obras: "De manhã, aqui no meu pequeno estúdio, o Crow's nest segundo - do Crow's nest primeiro já te falei no meu livro Feito à Mão (...)" 309; "Você, que já se habituou a vir pra este espaço, deve ter cansado de me ouvir falar de casas e, por extensão, de móveis. Mas fazer o quê? Se desde meus seis anos fiz minha primeira casa num galinheiro desativado da fazendola que tínhamos (...)" 310

Há também referências indiretas a outras personagens: “àquela afeição exagerada à madrinha e à mãe, acompanhava ora uma, ora outra, nos confortáveis sofás, um era estampado, o outro cor de morango, em que elas viam novelas de televisão." ${ }^{311}$ Referências indiretas a Alexandre, afeiçoado à madrinha dona da "casa mágica" que lhe supriria as necessidades; a Lucas, que era extremamente ligado à mãe; à gata namorada de Vítor, de $O$ sofá estampado, personagem que passava a maior parte da vida sobre o sofá estampado assistindo à televisão. Não apenas referências a personagens de outras obras, mas também às próprias técnicas de escritura, como o uso de didascálias, muito recorrente em Angélica, por exemplo. Abaixo segue um quadro-resumo de algumas dessas autorreferências:

\begin{tabular}{|c|c|c|}
\hline \multirow{2}{*}{ OBRAS } & RECURSOS E & RECURSOS E \\
TEMÁTICAS & TEMÁTICAS EM \\
& INTRAMUROS \\
\hline \multirow{2}{*}{ Os colegas } & Valorização da arte & Valorização da arte \\
& popular: artesanato & popular: artesanato \\
& (confecção de fantasias) & (confecção de bonecos) \\
\hline
\end{tabular}

\footnotetext{
${ }^{308}$ COSTA, Admar. Platão e o teatro das ideias. O que nos faz pensar, [S.1.], v. 23, n. 34, p. 125-146, mar. 2014. ISSN 0104-6675. Disponível em: http://www.oquenosfazpensar.fil.pucrio.br/index.php/oqnfp/article/view/409. Acesso em: 01 aug. 2019.

${ }^{309}$ BOJUNGA, Lygia. Intramuros. 1. ed. . Rio de Janeiro: Casa Lygia Bojunga, 2016, p.13.

${ }^{310}$ BOJUNGA, op. cit., p.58.

${ }^{311}$ BOJUNGA, op. cit., p.153.
} 


\begin{tabular}{|c|c|c|}
\hline \multirow{3}{*}{ Angélica } & Liberdade de Angélica & Liberdade de Nicolina \\
\hline & Angélica escritora de peça & $\begin{array}{c}\text { Nicolina escritora de suas } \\
\text { próprias falas na peça }\end{array}$ \\
\hline & Narrador como didascálias & $\begin{array}{l}\text { Narrador como didascálias } \\
\text { (Notas da Autora: N.A.) }\end{array}$ \\
\hline \multirow{4}{*}{ A bolsa amarela } & $\begin{array}{l}\text { Criação de universo para as } \\
\text { próprias personagens feita } \\
\text { pela protagonista }\end{array}$ & $\begin{array}{c}\text { Criação de universo para os } \\
\text { próprios bonecos feita pela } \\
\text { protagonista } \\
\text { Construção física dos } \\
\text { bonecos }\end{array}$ \\
\hline & $\begin{array}{c}\text { Importância significativa } \\
\text { dos objetos para a } \\
\text { protagonista }\end{array}$ & $\begin{array}{c}\text { Importância significativa } \\
\text { dos objetos para a } \\
\text { protagonista }\end{array}$ \\
\hline & $\begin{array}{c}\text { Criação literária de } \\
\text { personagens por meio do } \\
\text { gênero carta }\end{array}$ & $\begin{array}{c}\text { Criação literária de } \\
\text { personagens por meio de } \\
\text { artes mistas (literatura, } \\
\text { teatro) }\end{array}$ \\
\hline & $\begin{array}{c}\text { Identificação entre autor } \\
\text { (protagonista) e } \\
\text { personagem (Galo) }\end{array}$ & $\begin{array}{l}\text { Identificação entre autor } \\
\text { (Lygia Bojunga) e } \\
\text { personagem (Nicolina), } \\
\text { que se identifica com sua } \\
\text { criação, Nicolau. }\end{array}$ \\
\hline
\end{tabular}




\begin{tabular}{|c|c|c|}
\hline & Metáfora do céu cinzento & Metáfora do céu cinzento \\
\hline \multirow{3}{*}{ A casa da madrinha } & $\begin{array}{l}\text { A viagem de Alexandre em } \\
\text { busca da casa da madrinha }\end{array}$ & $\begin{array}{l}\text { A viagem da autora em } \\
\text { busca do significado de } \\
\text { Intramuros }\end{array}$ \\
\hline & $\begin{array}{c}\text { Amor do protagonita pela } \\
\text { madrinha }\end{array}$ & $\begin{array}{c}\text { Amor de Dr. Ricardinho } \\
\text { pela madrinha }\end{array}$ \\
\hline & $\begin{array}{l}\text { Multiplicidade de vozes } \\
\text { narrativas }\end{array}$ & $\begin{array}{c}\text { Multiplicidade de vozes } \\
\text { narrativas }\end{array}$ \\
\hline \multirow{3}{*}{ Corda Bamba } & $\begin{array}{l}\text { Caminhos que levam ao } \\
\text { autoconhecimento da } \\
\text { protagonista }\end{array}$ & $\begin{array}{l}\text { Caminhos que levam ao } \\
\text { autoconhecimento da } \\
\text { protagonista e da autora }\end{array}$ \\
\hline & $\begin{array}{c}\text { A transição entre universos } \\
\text { reais e imaginários }\end{array}$ & $\begin{array}{c}\text { A transição entre universos } \\
\text { reais e imaginários }\end{array}$ \\
\hline & $\begin{array}{c}\text { Personagem menina } \\
\text { equilibrista }\end{array}$ & $\begin{array}{c}\text { Menção a uma menina } \\
\text { equilibrista }\end{array}$ \\
\hline \multirow{3}{*}{ O sofá estampado } & $\begin{array}{c}\text { O buraco do sofá } \\
\text { estampado, que leva Vítor } \\
\text { para outro universo }\end{array}$ & $\begin{array}{c}\text { Os "buracos da autora" } \\
\text { sobre os quais a } \\
\text { protagonista fala }\end{array}$ \\
\hline & $\begin{array}{l}\text { Vítor e sua dificuldade em } \\
\text { expressar o que sente: o } \\
\text { processo de cavar toma } \\
\text { conta dele }\end{array}$ & $\begin{array}{l}\text { Nicolina e sua dificuldade } \\
\text { de expressar o que sente: o } \\
\text { riso toma conta dela. }\end{array}$ \\
\hline & $\begin{array}{c}\text { O sofá estampado, a TV e a } \\
\text { Gata telespectadora de } \\
\text { novela e que ignora o } \\
\text { protagonista }\end{array}$ & $\begin{array}{c}\text { O sofá estampado, a TV e as } \\
\text { mulheres da família da } \\
\text { protagonista que, ao verem } \\
\text { novela no Natal, ignoram } \\
\text { Nicolina. }\end{array}$ \\
\hline
\end{tabular}




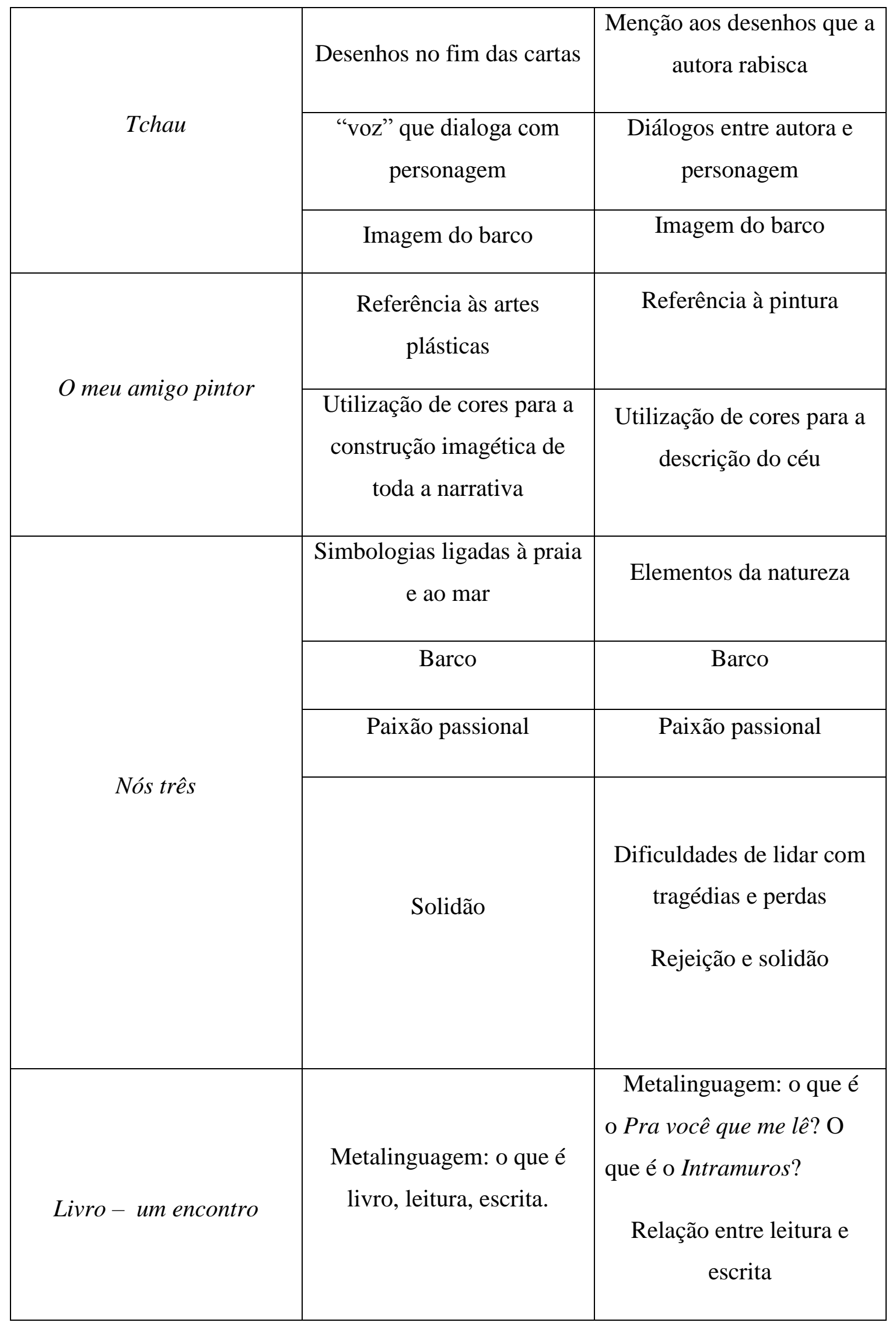




\begin{tabular}{|c|c|c|}
\hline \multirow[t]{2}{*}{ Livro - um encontro } & $\begin{array}{c}\text { Parte da biografia da } \\
\text { autora; }\end{array}$ & $\begin{array}{c}\text { Retomada de partes } \\
\text { biográficas já mencionadas } \\
\text { em outras obras. } \\
\text { Biografia retomada em } \\
\text { sentido de legado. }\end{array}$ \\
\hline & $\begin{array}{c}\text { Amor pela leitura sentido } \\
\text { pela autora }\end{array}$ & $\begin{array}{c}\text { Amor pela leitura sentido } \\
\text { pela autora. }\end{array}$ \\
\hline \multirow[t]{2}{*}{ Fazendo Ana Paz } & $\begin{array}{c}\text { Diálogo com os } \\
\text { personagens em processo } \\
\text { de criação: fluxo de } \\
\text { pensamento, início, } \\
\text { interrupção, destruição, } \\
\text { renovação de cada etapa da } \\
\text { escrita. }\end{array}$ & $\begin{array}{c}\text { Diálogo com os } \\
\text { personagens em processo } \\
\text { de criação: fluxo de } \\
\text { pensamento, início, } \\
\text { interrupção, destruição, } \\
\text { renovação de cada etapa da } \\
\text { escrita. }\end{array}$ \\
\hline & $\begin{array}{c}\text { Fragmentos de memórias } \\
\text { sobre casas e móveis da } \\
\text { vida da autora }\end{array}$ & $\begin{array}{c}\text { Fragmentos de memórias } \\
\text { sobre casas e móveis da } \\
\text { vida da autora }\end{array}$ \\
\hline Paisagem & $\begin{array}{l}\text { O "fazer" literatura com a } \\
\text { ajuda do leitor: limites } \\
\text { entre fantasia e realidade; a } \\
\text { desconfiança quanto às } \\
\text { afirmações do personagem- } \\
\text { leitor Lourenço }\end{array}$ & $\begin{array}{l}\text { O “fazer” literatura com a } \\
\text { ajuda das personagens, o } \\
\text { leitor é silencioso, está no } \\
\text { Pra você que me lê; limites } \\
\text { entre fantasia e realidade; a } \\
\text { desconfiança quanto às } \\
\text { afirmações da autora e de } \\
\text { Nicolina, já que esta se } \\
\text { define como mentirosa. }\end{array}$ \\
\hline
\end{tabular}




\begin{tabular}{|c|c|c|}
\hline Paisagem & $\begin{array}{l}\text { O cansaço que a autora } \\
\text { sente ao escrever muito a } \\
\text { ponto de dormir. }\end{array}$ & $\begin{array}{l}\text { O cansaço que Nicolina } \\
\text { sente ao se comunicar } \\
\text { muito a ponto de dormir. }\end{array}$ \\
\hline \multirow{2}{*}{ Seis vezes Lucas } & $\begin{array}{l}\text { Cachorro: forma de } \\
\text { combate ao medo e à } \\
\text { solidão. }\end{array}$ & $\begin{array}{l}\text { Bonecos: forma de } \\
\text { combate ao medo e à } \\
\text { solidão. }\end{array}$ \\
\hline & $\begin{array}{l}\text { Relação maternal: amor de } \\
\text { Lucas para com a mãe }\end{array}$ & $\begin{array}{c}\text { Diferentes tipos de relação } \\
\text { maternal }\end{array}$ \\
\hline \multirow[b]{2}{*}{ O abraço } & $\begin{array}{c}\text { Lembranças sombrias da } \\
\text { infância }\end{array}$ & $\begin{array}{c}\text { Lembranças sombrias da } \\
\text { infância }\end{array}$ \\
\hline & $\begin{array}{l}\text { Morte de personagem } \\
\text { criança e de jovem } \\
\text { Cenas de violência }\end{array}$ & $\begin{array}{l}\text { Protagonista, quando } \\
\text { criança, quase mata a } \\
\text { própria mãe } \\
\text { Cenas de violência }\end{array}$ \\
\hline \multirow[b]{2}{*}{ Feito à mão } & $\begin{array}{l}\text { Técnicas artesanais para } \\
\text { escrever a obra; um tipo de } \\
\text { forma artesanal para o livro }\end{array}$ & $\begin{array}{c}\text { Técnicas artesanais de } \\
\text { produção de personagens } \\
\text { (bonecos); }\end{array}$ \\
\hline & $\begin{array}{l}\text { Construir lugares para se } \\
\text { isolar para escrever } \\
\text { (Crow's New, galinheiro } \\
\text { em casa, Boa Liga no } \\
\text { sítio), visitar lugares } \\
\text { inspiradores (Cidade do } \\
\text { México) }\end{array}$ & $\begin{array}{l}\text { Necessidade de um lugar } \\
\text { para se isolar a fim de } \\
\text { construir bonecos }\end{array}$ \\
\hline
\end{tabular}




\begin{tabular}{|c|c|c|}
\hline Feito à mão & $\begin{array}{l}\text { Necessidade da autora em } \\
\text { fazer um livro com as } \\
\text { próprias mãos }\end{array}$ & $\begin{array}{c}\text { Necessidade da autora de } \\
\text { deixar seu legado (Boa } \\
\text { Liga) }\end{array}$ \\
\hline \multirow{2}{*}{ O Rio e eи } & $\begin{array}{l}\text { O afastamento do lugar que } \\
\text { se ama } \\
\text { Comparações entre Rio e } \\
\text { Londres; }\end{array}$ & $\begin{array}{c}\text { Migrações entre Rio e } \\
\text { Londres }\end{array}$ \\
\hline & $\begin{array}{l}\text { Questionamento sobre a } \\
\text { profissão de escritora: } \\
\text { necessidade financeira ou } \\
\text { amor pelo que se faz? }\end{array}$ & $\begin{array}{l}\text { Questionamento da autora } \\
\text { sobre ter voltdo a escrever } \\
\text { como na época da TV e do } \\
\text { rádio }\end{array}$ \\
\hline \multirow[t]{3}{*}{ Retratos de Carolina } & $\begin{array}{c}\text { Sentimentos da infância } \\
\text { (amizade, maldade, } \\
\text { curiosidade sexual), a } \\
\text { ilusão do "homem certo", a } \\
\text { violência, a desconstrução } \\
\text { do romantismo maternal }\end{array}$ & $\begin{array}{l}\text { Sentimentos da infância } \\
\text { (amizade, maldade, } \\
\text { curiosidade sexual), a } \\
\text { ilusão do "homem } \\
\text { perfeito", a violência, a } \\
\text { desconstrução do } \\
\text { romantismo maternal }\end{array}$ \\
\hline & Carolina escreve no livro & Nicolina escreve no livro \\
\hline & $\begin{array}{c}\text { Carolina dialoga com a } \\
\text { autora }\end{array}$ & $\begin{array}{c}\text { Nicolina dialoga com a } \\
\text { autora }\end{array}$ \\
\hline \multirow[b]{2}{*}{ Aulas de inglês } & Expressões fotográficas & Expressões fotográficas \\
\hline & $\begin{array}{l}\text { A espera longa do } \\
\text { protagonista pela } \\
\text { realização amorosa. }\end{array}$ & $\begin{array}{l}\text { A espera longa de Rosário } \\
\text { pela realização amorosa. }\end{array}$ \\
\hline Sapato de salto & $\begin{array}{c}\text { Existência de uma } \\
\text { personagem homossexual }\end{array}$ & $\begin{array}{c}\text { Existência de uma } \\
\text { personagem homossexual }\end{array}$ \\
\hline
\end{tabular}




\begin{tabular}{|c|c|c|}
\hline \multirow{2}{*}{ Sapato de salto } & $\begin{array}{c}\text { Abuso sexual sofrido pela } \\
\text { protagonista }\end{array}$ & $\begin{array}{c}\text { Abuso sexual sofrido pela } \\
\text { protagonista }\end{array}$ \\
\hline \multirow{2}{*}{ Querida } & O amor de Ella ao teatro & O amor de Lygia ao teatro \\
\cline { 2 - 3 } & $\begin{array}{c}\text { Máscara do Ciúmes, } \\
\text { ciúmes de Pacífico e de } \\
\text { Pollux }\end{array}$ & Ciúmes de Nicolina \\
\hline
\end{tabular}

Essa autorreferência por meio da qual a obra Intramuros é construída -sobretudo acerca das personagens que tendem não só a rememorar acontecimentos passados da vida da autora, como também a ajudá-la na busca por si mesma -, diferenemente da obra Fazendo Ana Paz, não se limita ao autoconhecimento do passado. O passado é resgatado em forma de legado, de tudo o que deixará por meio do que consegiu construir graças ao seu amor pelo livro. Volta-se ao assunto inicial da primeira obra da trilogia (leitura), que é exatamente como Bojunga termina Intramuros, afirmando que gastará suas horas disponíveis com a leitura, sugerindo, assim, que Intramuros percorre muitos dos caminhos das obras anteriores e faz o trajeto contrário ao da trilogia Livro - um encontro, Fazendo Ana Paz e Paisagem. 
A tarefa do escritor só se completa com o leitor.

Lygia Bojunga

Geralmente sabemos quando um livro, quando uma frase, quando um personagem é importante na nossa vida. Sabemos bem quando um personagem abre uma cortina para nós...

Lygia Bojunga

Para mim, o que me dá mais prazer é reler um livro que eu gostei.

É aí que você vê como um livro é rico, é aí que você vê como um livro tem várias leituras...

(...)

É o espelho.É um espelho precioso. Acho que nem mesmoo bom teatro, que eu tanto amo, é capaz de nos passar esse espelho que a literatura nos dá. Porque a intimidade com um livro nos transforma, essa intimidade nos transforma mesmo. Dependendo das circunstâncias pode até não ser para melhor. Mas, de um modo ou de outro, nós vamos sair do outro lado como seres enriquecidos. 


\section{CONCLUSÕES}

Lygia Bojunga escreve sua literatura pautada no teatro, pois somente unindo seu amor pelo livro - via produção de sua própria literatura - e o seu amor pelo teatro - via utilização de recursos teatrais na produção literária - é que a autora consegue construir o seu próprio palco e transformar em cena qualquer ideia que tenha, seja a criação de uma personagem que culminará em uma narrativa, seja a memória de acontecimentos de sua vida, seja o comentário sobre o processo de criação de uma obra, seja um assunto que é tratado de forma mais lúdica ou mais realista.

A relação entre teatro e literatura está, portanto, presente em toda a obra da autora de modo a tornar sua literatura mais teatral e visual, ajudando a construção de um universo imagético, o que foi comprovado ao serem analisados trechos das obras de Bojunga em que a autora coaduna recursos de outras artes a recursos literários. No que concerne ao cinema, alguns recursos exemplificados foram os tipos tanto de movimento de câmera quanto de enquadramento de planos, além de serem abordados, também, os recursos de iluminação, sendo estes reproduzidos verbalmente via foco narrativo, escolha lexical e utilização de cores, de descrição e de figuras de linguagem. Os recursos da música, como ritmo, tempo e gênero - no caso, o samba -, foram captados literariamente por meio dos aspectos gráficos que separam a letra da música do restante da narrativa-, da reprodução da letra dos sambas em versos eufônicos, da oralidade presente na escrita da letra da música, da sinestesia e do uso da pontuação. Os recursos pictóricos utilizados, por sua vez, foram as cores, suas tonalidades e sua iluminação, que foram impressos no registro verbal por meio da descrição das cores, da construção de metáforas temporais e da escolha lexical e gramatical em função da semântica textual. Já na dança, a relação entre espaço e emoção é visualmente reproduzida pela descrição dos movimentos corporais das personagens. Por fim, os recursos da fotografia, pautados em enquadramentos e na relação entre ângulo-cenário, são construídos a partir da descrição detalhada de partes do corpo das personagens, garantindo-lhes maior expressividade, tal qual a de um ator em cena.

Após se ter demonstrado esses recursos, tratou-se do drama clássico enquanto gênero literário e enquanto teatro. A partir dessa análise, notou-se que nenhuma obra da autora pode ser classificada dentro de um único gênero teatral, visto que constataram-se variados tipos de recursos de teatro presentes em uma mesma obra. Ademais, foi analisada a importância da 
relação entre ação e tempo no Teatro Clássico, sobretudo no que diz respeito à coerência orgânica das narrativas, sejam elas cronológicas ou não. Acerca dessa relação, teorizou-se a composição do discurso teatral e o modo por meio do qual Lygia Bojunga o constrói, principalmente no que concerne aos gestos - maior presença do narrador, escolha lexical e gramatical adequada ao campo semântico da cena retratada - e ao diálogo, que, como característica marcante da autora, foi trabalhado ao longo de toda a análise.

Considerando a análise completa, o diálogo, recurso que é tanto literário quanto teatral, foi utilizado de diferentes formas: entre personagens, entre personagem-autora e outras personagens, entre autora e personagens que estão sendo criadas, entre autora e leitor - como no caso do Pra você que me lê, que configura uma forma de distanciamento épico, recurso, portanto, do Teatro Épico; entre personagem e leitor - como acontece em Intramuros, já que Nicolina conversa com o leitor, haja vista que esta se encontra no Pra você que me lê. Assim sendo, o diálogo não é apenas uma técnica que se limita a dar expressão e vivacidade às personagens, mas também envolve o leitor na trama, tendo seu ápice em Intramuros, em que a autora conclui seu projeto de vida e de arte, metaforizado na personagem Nicolina, que dialoga com o leitor. Nesse sentido, o leitor de Lygia Bojunga é incluído no projeto da autora Lygia, de modo a reconhecer as autorreferências e a ligação destas, tanto com a vida, quanto com outras obras da autora.

Além do comentário do narrador/autor sobre a peça, que promove o rompimento da ilusão teatral, ilusão essa típica do Teatro Clássico, foram analisados também outros recursos do Teatro Épico: a promoção da reflexão sobre os determinantes sociais relacionados a um problema - como ocorre em Sapato de salto com o assunto prostituição infantil e em Retratos de Carolina com a temática independência feminina-, que, por sua vez, se vinculam ao intuito didático do Teatro Épico; a ausência de linearidade cronológica, o que rompe com as regras do Teatro Aristotélico; a utilização de personagens marginalizadas, seja pela pobreza, seja por não seguirem padrões sociais pré-estabelecidos, como acontece na maior parte das obras de Lygia Bojunga, independentemente de a obra ser ou não mais realista. Além disso, com o capítulo acerca do Teatro Épico, reforçou-se a ideia de que a obra da autora não se enquadra em esquemas, como os que opõe Teatro Dramático a Teatro Épico, já que o fato de obras de cunho mais social apresentarem mais recursos deste teatro não significa que não possa ter recursos de outros, como o Clássico. 
Acerca do Teatro Mambembe, bastante valorizado por Lygia Bojunga, demonstrou-se a presença da arte popular na literatura da autora, a partir da análise de três obras - Os colegas, Corda bamba e A casa da madrinha -, obras essas que formaram uma trilogia de tipos de Teatro Mambembe: o Teatro Itinerante, o Teatro Circense e o Teatro de Rua. Todos esses tipos têm em comum a abordagem do deslocamento espacial, porém com temáticas diferenciadas ligadas à arte Mambembe: improviso, artesanato, vida nômade circense e saltimbanco.

O Teatro de Animação, por sua vez, está presente na literatura da autora, já que esta comumente transforma objetos em personagens, recurso primordial desse tipo de teatro. A função dos objetos é a de concatenar as narrativas que se desenvolvem ao longo da obra ou a de metaforizar um assunto trabalhado na cena ou na obra, inclusive de modo a se tornarem síntese de uma personagem. Além da metáfora como recurso literário, a personificação dos objetos é recorrente. Independentemente do recurso literário empregado para expressar o recurso do Teatro de Animação, os objetos alcançam notoriedade e realçam os assuntos tratados nas cenas, tais como a dificuldade de se lidar com o mundo externo, a alteridade, a formação da identidade, a mudança de construção da personagem, a transgressão entre o real e o sobrenatural. Este último tema foi muito retratado por meio dos recursos do Teatro das Sombras, oriundo do Teatro de Animação. Estes recursos foram utilizados literariamente, principalmente, por meio da referência à iluminação, que, por sua vez, está relacionada a temáticas de solidão, terror e morte, como foi analisado em $O$ abraço e em Nós três.

Por fim, analisou-se como os recursos do Metateatro se aplicam às obras da autora, que apresentam recursos metateatrais relacionados aos recursos metalinguísticos. Para isso, explicou-se a definição de Teatro Dentro do Teatro por meio da obra Angélica, que tem estrutura de peça teatral e reproduz em si outra peça, explicitando, também, outros recursos metateatrais, que demonstram todas as etapas de elaboração de uma peça de teatro. Outrossim, analisou-se, nessa perspectiva, a trilogia de obras que Lygia Bojunga formou como um projeto literário, a fim de unir o seu eu-leitora ao seu eu-escritora, análise essa que permitiu a conclusão de que Intramuros percorre a trajetória inversa da trilogia, principalmente no confronto com Paisagem. Também de maneira constrastante, tanto Intramuros quanto Fazendo Ana Paz são obras de cunho metalinguístico e metateatral no que concerne à construção das personagens e, consequentemente, ao fazer literário. Constatou-se que tanto o processo de criação de Ana Paz, quanto o de Nicolina partem da autobusca da escritora, baseada em memórias, que, no caso de Ana Paz, auxiliaram, parcialmente, o 
processo de criação da personagem, diferentemente de Nicolina, visto que não apenas as memórias da autora, como também seus afazeres - atividades essas relacionadas ao legado da autora - protelaram a escrita de Intramuros. A demora na escritura desta obra foi de extrema importância, pois foi a partir desse processo de busca pela significação da personagem e do título da obra, que se pôde constatar que essa delonga foi proposital, uma vez que a história da protagonista e toda a narrativa de Intramuros coincidiu com o projeto literário de Lygia Bojunga, que, por sua vez, foi difundido como seu projeto de vida, resultando em um legado não apenas cultural, mas também social, já que a autora é criadora e mantenedora de uma fundação, que procura disseminar vários dos seus interesses: a natureza, o artesanato, o livro, a literatura e, obviamente, o teatro. Por fim, conclui-se que, tendo cumprido seu projeto de vida ligado à arte, o que restou foi a última etapa do trajeto inverso de sua trilogia: voltar para onde tudo começou - a leitura, a Lygia leitora -, assunto esse tratado no monólogo Livro - um encontro, primeiro texto escrito para encenação, que, em Intramuros, é resgatado também via palco, porém via um "literapalco":

Tem outra coisa que ainda quero te dizer: já faz algum tempo que eu venho sentindo o desejo/necessidade de alargar as minhas horas disponíveis a fim de ficar relendo os autores queridos e lendo os que ainda não tive tempo de ler. É isto que ando fazendo. E, neste fazer, estou me reencontrando com o eu do tempo em que eu era 'só' leitora.

Quem sabe, então, estou voltando ao ponto de partida da minha relação com o Livro e da intenção que tive mais tarde de fazer um 'redondo' com ele? Pois é... ${ }^{312}$

Sugeriu-se que a autora fez sua última obra, e que, a partir de então, será apenas leitora e usará seu tempo para deixar seu legado. Essa foi somente uma possível leitura, visto que a autora assina o Pra você que me lê, que coincide com o final da obra com a sua frase recorrente: “Até o nosso próximo encontro". Será esse próximo encontro uma nova obra ou os encontros que o leitor terá ao fazer, como a autora, relendo os escritores favoritos, entre eles a própria Lygia?

$\overline{{ }^{312} \text { BOJUNGA, Lygia. Intramuros. }}$ 1. ed. . Rio de Janeiro: Casa Lygia Bojunga, 2016, p.182. 


\section{REFERÊNCIAS}

ABEL, Lionel. Metateatro, uma visão nova da forma dramática.Tradução: Bárbara Heliodora. Rio de Janeiro: Zahar, 1968.

AIRES, Eliane Gabriel. O processo de criação literária em Lygia Bojunga Nunes: leitura e escrita postas em jogo pela ficção. 2003. Tese (Doutorado em Letras) - Universidade Estadual Paulista “Júlio de Mesquita Filho”, São José do Rio Preto.

AMARAL, Ana Maria de. Teatro de animação: da teoria à prática. São Caetano do Sul: Ateliê, 1997.

ANDRADE, Carlos Drummond. A rosa do povo. São Paulo: Companhia das Letras, 2019.

ANDO, Marta Yumi. Do texto ao leitor, do leitor ao texto: um estudo sobre Angélica e $\boldsymbol{O}$ Abraço de Lygia Bojunga Nunes. 2006.179f. Tese (Mestrado em Estudos Literários) Universidade Estadual de Maringá, Maringá.

Fazendo retratos e experimentos: a performance da linguagem em Lygia Bojunga. São José do Rio Preto, 2011. 226. Tese (Doutorado em Letras). Universidade Estadual Paulista Júlio de Mesquita Filho, UNESP.

ARISTÓTELES. Poética. Tradução de Paulo Pinheiro.São Paulo, Editora 34, 2015.

ARTAUD, Antonin. O teatro e seu duplo. São Paulo: Martins Fontes, 2012.

AZEVEDO, Artur. Teatro de Artur Azevedo V/ Artur Azevedo; estabelecimento de texto por Antônio Martins de Araújo. Rio de Janeiro: FUNARTE, 1995.

BARTHES, Roland. A câmara clara: nota sobre fotografia. $3^{a}$ ed. Rio de Janeiro: Nova Fronteira, 1989.

BELTRANE, Valmor, org. Teatro de sombras: técnica e linguagem. Florianópolis: Departamento de Artes Cênicas/UDESC, 2005.

BERTHOLD, Margot. História Mundial do Teatro. Ttradução Maria Paula, v. Zurawski, J. Guinsburg, Sérgio Coelho e Clóvis Garcia - 6. Ed. São Paulo: Perspectiva, 2014.

BOJUNGA, Lygia. A bolsa amarela. Casa Lygia Bojunga, Rio de Janeiro, 2013.

.A cama. $1^{\mathrm{a}}$ ed. Rio de Janeiro: Editora Agir, 2002.

.Aula de inglês. Rio de Janeiro: Casa Lygia Bojunga, 2006.

Corda bamba. 24. ed. Rio de Janeiro: Casa Lygia Bojunga, 2009. 
. Dos vinte 1. Rio de Janeiro: Casa Lygia Bojunga, 2007.

. Fazendo Ana Paz. Casa Lygia Bojunga, Rio de Janeiro, 2013.

. Feito à mão. 4. ed. Rio de Janeiro: Casa Lygia Bojunga, 2008.

. Intramuros. 1. ed. Rio de Janeiro: Casa Lygia Bojunga, 2016.

. Livro - um encontro. 6. ed. Rio de Janeiro: Casa Lygia Bojunga, 2007.

. Nós três. 4. ed. Rio de Janeiro: Casa Lygia Bojunga, 2008.

. O abraço. 6. ed. 3. imp. Rio de Janeiro: Casa Lygia Bojunga, 2014.

. Os colegas. 52.ed. Rio de Janeiro: Casa Lygia Bojunga, 2014.

. Paisagem. 7.ed. Rio de Janeiro: Casa Lygia Bojunga, 2013.

. Querida. Rio de Janeiro: Casa Lygia Bojunga, 2009.

. Retratos de Carolina. Rio de Janeiro: Casa Lygia Bojunga, 2002.

. Sapato de salto. Rio de Janeiro: Casa Lygia Bojunga, 2006.

Tchau. 19. ed. Rio de Janeiro: Casa Lygia Bojunga, 2012.

BORDWELL, David. Sobre a história do estilo cinematográfico.Tradução: Luis Carlos Borges.Campinas, SP: Editora Unicamp, 2013.

BORDWELL, David; THOMPSON, Kristin. A arte do cinema: uma indtrodução. Tradução de Roberta Gregoli. - Campinas, SP: Editora Unicamp; São Paulo, SP: Editora da USP, 2013.

BORNHEIM, Gerd. Brecht: a estética do teatro. Rio de Janeiro, Graal, 1992.

BOTELHO JUNIOR, Francisco Cassiano. A imagem fotográfica e o 'real'. 1981. 271f. Dissertação (Mestrado em Artes) - Universidade de São Paulo, São Paulo.

BOUCOURECHLIEV, André; tradução de António Maia da Rocha. A linguagem musical. Lisboa: Ed. 70, 2003.

BOURDIEU, Pierre. Sobre a televisão. Rio de |Janeiro: Jorge Zahar, 1997.

BRECHT, Bertolt. A cruzada infantil. Tradução de Tercio Redondo, ilustração de Carme Sole Vendrell. São Paulo: Editora Pulo do Gato, 2014.

Estudos sobre o teatro. Tradução: Fiama Pais Brandão. 2a ed. Rio de Janeiro: Editora Nova Fronteira, 2005. 
BRITO, Rubens de Souza. O grupo de teatro Mambembe e o Circo Teatro. Sala Preta, v. 6, p. 79-85, 28 nov. 2006.

BROUGÉRE, Gilles. A criança e a cultura lúdica. In: Rev. Fac. Educ. vol.24, n.2, São Paulo, July/Dec, $1998 . \quad$ Disponível em: http://www.scielo.br/scielo.php?script=sci_arttext\&pid=S0102-25551998000200007. Acesso em: 29 jul. 2019.

CÂMARA, Ana Letícia Pires Leal. Para Lygia Bojunga, a mulher que mora nos livros. Rio de Janeiro, 2010. 254f. Tese (Doutorado em Letras) - Pontifícia Universidade Católica do Rio de Janeiro, Rio de Janeiro.

CASA LYGIA BOJUNGA. [homepage] Disponível em: http://www.casalygiabojunga.com.br/pt/. Acesso em: 01 ago.2019.

CELESTINO, Phelippe; MARTINS, Ferdinando. Uma quimera quase real:a burleta $O$ Mambembe de Arthur Azevedo e José Piza. PÓS: Revista do Programa de Pós-graduação em Artes da EBA/UFMG. v.8, n.15: mai.2018. Disponível em: https://eba.ufmg.br/revistapos

CENTRO CULTURAL MINISTÉRIO DA SAÚDE. [homepage]. Museu de Imagens do Inconsciente. Disponível em: http://www.ccs.saude.gov.br/cinquentenario/carlos.html. Acesso em 01 ago. 2019

COELHO, Nelly Novaes. A literatura infantil: história, teoria, análise: das origens orientais ao Brasil de hoje. São Paulo, Quíron, 1981.

COSTA, Admar. Platão e o teatro das ideias. In: O que nos faz pensar nº34, março de 2014.

COSTA, Felisberto. A poética de ser e não ser: procedimentos dramatúrgicos do teatro de animação. São Paulo: Edusp, 2000.

COSTA, I. Brecht e o teatro épico. Literatura e Sociedade, v. 15, n. 13, p. 214-233, 29 jun. 2010.

COSTA, Lígia Militz da. Representação e teoria da literatura: dos gregos aos pósmodernos. Cruz Alta, Unicruz, 2001.

COUTINHO, Afrânio. A literatura no Brasil: introdução geral. São Paulo: Global, 2004.

CRISTÓFANO, Sirlene. Lygia Bojunga e a literatura infanto-juvenil: uma crítica lúdica e abordagem à realidade social. Disponível em: www.revistas.usp.br/linhadagua/article/download/37337/40057. Acesso em: 27 jan.2018.

Dicionário de símbolos online. [homepage]. Disponível em: https://www.dicionariodesimbolos.com.br. Acesso em: 07 abr.2017.

DINIZ, Amorim Arthur. Metateatro, monodrama e o papel do dramaturgo em um processo colaborativo, p.6. Artigo Disponível em: https://www.eba.ufmg.br/cadernodeencenacao/index.php/revista/article/viewFile/35/34 Acesso em: 27 abr.2017. 
FERNANDES Sílvia e J. Guinsburg. O pós-dramático. São Paulo: Perspectiva, 2013.

FIGUEIREDO, E. Autoficção feminina: a mulher nua diante do espelho. Revista Criação \& Crítica, n. 4, p. 91-102, 15 abr. 2010.

FRANK, Porchan.The Semiotic Study of Puppets, Masks and Performing Objects. Semiótica, vol. 47, 1983.

FUNDAÇÃO NACIONAL DO LIVRO. [homepage]. Entrevista com Lygia Bojunga por Márcio Vassallo. Disponível em: https://www.fnlij.org.br/site/jornalnoticias/item/download/234_b7d6bfef22bb42bfa3619a22852ea737.html. Acesso em: 01 ago.2019.

FURTADO, Marli Terezinha. Bertold Brecht e o teatro épico. Disponível em: https://periodicos.ufsc.br/index.php/fragmentos/article/download/4826/4132. Acesso em: 25 abr. 2019.

GIORDANO, Davi. Teatro Político: Panorama crítico sobre o conjunto temático da obra artística e teatral de Vsévolod Meyerhold; e seus pontos comparativos com o teatro de Erwin Piscator e Bertolt Brecht. II Congreso Internacional Artes en Cruce: bicentenarios latinoamericanos y globalización. Universidade Federal do Rio de Janeiro. Disponível em: http://artesencruce.filo.uba.ar/sites/artesencruce.filo.uba.ar/files/14ArteyPolitica-Giordano.pdf Acesso em: 29 jul. 2019.

GOMES, Cristina.O cheiro das palavras: o olfato na narrativa literária. 2009. 118 f. Dissertação (Mestrado em Letras) - Pontifícia Universidade Católica do Rio Grande do Sul, Rio Grande do Sul.

GUINSBURG, J.; NETTO, J. Teixeira Coelho; CARDOSO, Reni Chave. Semiologia do teatro. São Paulo, Perspectiva, 2003.

HOLANDA, Chico Buarque de. Mambembe. Quando o Carnaval chegar. Polygram, 1972.

HOUAISS, Antonio; VILLAR, Mauro de Sales. Dicionário Houaiss da língua portuguesa, elaborado pelo Instituto Antonio Houaiss de Lexicografia e Bancos de Dados da Língua Portuguesa S/C Ltda. Rio de Janeiro: Objetiva, 2009.

HUNT, Peter. Crítica, teoria e literatura infantil. São Paulo, Cosac-Naify, 2010.

IWATA, Tatiana; MARANHA, Fernanda. Circo: reelaboração de uma cultura. Revista PsicoUSP. Disponível em: http://www.ip.usp.br/revistapsico.usp/index.php/arte-e-cultura/12-circoreelaboracao-de-uma-cultura. Acesso em: 30 ago. 2019.

KANTOR, Tadeusz. O teatro da morte. São Paulo: Perspectiva, Edições SESC SP, 2008.

LARANJA, R. da Costa Michele. Identidade marginal na Literatura para crianças e jovens: os personagens de Lygia Bojunga.2009. 122f. Dissertação (Mestrado em Letras) Universidade Estadual Paulista , São José do Rio Preto. 
LIMA, Augusto de; PASCOLATTI, Sonia. Autoficção como recurso metateatral em Fernando Abreu, Ricardo Scripta Uniandrade, Curitiba, PR, v. 12, n. 1 (2014), p. 106-123. Data de edição: 27 jun. 2014.

LOTTERMANN, C. Escrever para armazenar o tempo: morte e arte na obra de Lygia Bojunga. Curitiba, 2006.202f. Tese (Doutorado em Letras). Universidade Federal do Paraná.

MANCINI, Gabriella. Folha de São Paulo em 29/04/2012. Disponível em: http://www1.folha.uol.com.br/folhinha/2012/04/1083001-escritores-falam-sobre-lygiabojungahomenageada-no-salao-do-livro.shtml?mobile. Acesso em: 09 nov.2015.

MARTINS, Pedro Haddad. O metateatro como instrumento para a formação teatral de alunos-atores entre 8 e 12 anos. 2011. 179f. Dissertação (Mestrado em Artes) Universidade Estadual de Campinas, Instituto de Artes, São Paulo.

MARTINS, Taiana Renata; ALVAREZ, Gabriel. A identidade circense, seus símbolos e rituais sob a lona. Reflexões sobre o circo e suas performaces. Disponível em: https://eiap2011.files.wordpress.com/2011/05/taiana-martins-gt-1.pdf.Acesso em: 05 mai.2019

MENDES, Maria dos Prazeres Santos. Monteiro Lobato, Clarice Lispector, Lygia Bojunga Nunes: o estético em diálogo na literatura infanto-juvenil. 1994. 265 f. Tese (Doutorado em Comunicação e Semiótica) - Pontifícia Universidade Católica de São Paulo, São Paulo.

MEYER, MANOELA. Literatura: Lygia Bojunga. Revista Educar para crescer, em 09/04/2012. Disponível em: http://educarparacrescer.abril.com.br/leitura/lygia-bojunga681657.shtml. Acesso em: 09 nov.2015.

MOISES, Maussad. Dicionário de termos literários. São Paulo: Cultrix, 2013.

NEVES, Vanderson de Souza; PASCOLATI, Sonia Aparecida Vido. O metateatro na obra o Rei da vela de Oswald de Andrade: criação de uma gramática de recursos metateatrais, p.4. Disponível em:http://www.uel.br/eventos/sepech/sepech08/arqtxt/resumosanais/VandersonSNeves.pdf. Acesso em: 07 jul. 2019

NUNES, Lygia Bojunga. A casa da madrinha. 9. ed. Rio de Janeiro: Agir, 1986.

A cama. Rio de Janeiro: Agir, 2002.

Angélica. Rio de Janeiro: Agir; Brasilia, INL, 1975.

O meu amigo pintor. Rio de Janeiro: José Olympio, 1987.

O sofá estampado. 9. ed. Rio de Janeiro: José Olympio, 1988.

Seis vezes Lucas. Rio de Janeiro: Agir, 1996.

PASCOALATI, Sonia. Em busca de uma poética Pirandelliana. São José do Rio Preto: Olho d’água, 3(1): 1-190, 2011. 
PAPES, Cleide da Costa e Silva. A vivência e a invenção no cotidiano em Rosa, minha irmã Rosa (Alice Vieira) e O sofá estampado (Lygia Bojunga). São Paulo, 2002. 156p. Tese (Doutorado em Letras - Literatura Portuguesa) - Universidade de São Paulo.

PAVIS, Patrice. Dicionário de teatro. São Paulo: Perspectiva, 2015.

PEREIRA, Olga Arantes. Cinema e Literatura: dois sistemas semióticos distintos. Revista Kalíope, v.5, n.10, 2009. Disponível em: https://revistas.pucsp.br/kaliope/article/view/7471/0. Acesso em: 09 jun.2019.

PETER, Cris. O uso das cores. Rio de Janeiro: Marsupial Editora, 2014.

PISCATOR, ERWIN. Political Theatre. Reino Unido: Methuen Drama, 2007.

PLATÃO. A República. Tradução: J. Guinsburg. São Paulo: Perspectiva, 2016.

RÁDIO E TELEVISÃO EDUCATIVA DO PARANÁ. O circo e a tradição mambembe. Disponível em: http://www.paranaeducativa.pr.gov.br/2016/06/3968/O-circo-e-a-tradicao-doteatro-mambembe.html. Acesso em: 10 jun. 2019.

RAMALHO, Denise do Passo Trocando tarefas: meu caso de amor de leitora com a obra de Lygia Bojunga. 2006. 122 f. Tese (Doutorado em Literatura Brasileira) -Departamento de Letras do Centro de Teologia e Ciências Humanas, Pontifícia Universidade Católica- RJ, Rio, Rio de Janeiro.

READ, Herbert. A arte de agora agora. Tradução J. Guinsburg e Janete Meiches. São Paulo: Perspectiva, 1981.

RICHE, Rosa Maria Cuba. A literatura infantil e juvenil contemporâneas e o retorno do trágico: o caso Lygia Bojunga, in: Heróis contra a parede - Estudos de literatura infantil e juvenil. São Paulo, Cultura Acadêmica, 2010.

.O feminino na literatura infantil e juvenil brasileira: poder, desejo, memória e os casos Edy Lima, Lygia Bojunga Nunes e Marina Colasanti. Rio de Janeiro, 1996. 255p. Tese (Doutorado em Letras) - Faculdade de Letras. Universidade Federal do Rio de Janeiro.

ROUBINE, Jean-Jacques. Introdução às grandes teorias do teatro. Rio de Janeiro: Jorge Zahar, 2003.

ROSENFELD, Anatol. Brecht e o teatro épico. São Paulo: Perspectiva, 2012.

.O teatro épico. São Paulo, Perspectiva, 2004.

SANDRONI, Laura. De Lobato a Bojunga : as reinações renovadas. Rio de Janeiro, Agir, 1987.

SANTOS, Cristina Sabin dos. Um olhar sobre contos fantásticos. Disponível em: http://meuartigo.brasilescola.uol.com.br/literatura/um-olhar-sobre-contos-fantasticos.html. Acesso em: 25 jan.2017. 
SILVA, Igor de Almeida. A vertigem das máscaras: metateatralidade na Compahia Teatro de Seraphim, 2014. 194 f. Tese (Doutorado em Artes) - Universidade de São Paulo, São Paulo.

SILVA, Rosa Maria Graciotto. Da casa real à casa sonhada: o universo alegórico de Lygia Bojunga Nunes. 1996. 248p. Tese (Doutorado em Letras) - Universidade Estadual Paulista “Júlio de Mesquita Filho", São José do Rio Preto.

SILVA, Vítor Manuel de Aguiar e. Teoria da literatura. Coimbra: Livraria Almedina, 1983.

SILVEIRA, Luciana Martha. Introdução à teoria da cor. Curitiba: UTFPR: 2011.

STAM, Robert. Introdução à teoria do cinema. Tradução Fernando Mascarello São Paulo: Papirus, 2000.

STOA USP. Disponível em: https://social.stoa.usp.br/articles/0047/2919/Planos_de_enquadramento_6_.pdf. Acesso em: 28 jul.2019.

TEIXEIRA, Carlos Henrique; MONTEIRO, Sueli Aparecida Itman. A dança como expressão do imaginário. Revista Ibero-Americana de Estudos em Educação, p.158. Disponível em: https://periodicos.fclar.unesp.br/iberoamericana/article/download/5716/4447. Acesso em: 07 jun.2019

UBERSFELD, Anne. Para ler o teatro. São Paulo, Perspectiva, 2005.

WELLEK, René; WARREN, Austin. Teoria da literatura e metodologia dos estudos literários. São Paulo, Martins Fontes, 2003.

WILLIAMS, Raymond. Drama em cena. São Paulo, Cosac-Naify, 2010.

WINNICOTT, Donald. O brincar e a realidade. Rio de Janeiro: Imago, 1975.

WILTGEN, Ana Beatriz. Itinerância: um conceito em trânsito na cena brasileira. VI Congresso de Pesquisa e Pós-Graduação em Artes Cênicas, 2010. Disponível em: http://www.portalabrace.org/vicongresso/territorios/Ana\%20Beatriz\%20Wiltgen\%20$\% 20$ Itiner\%E2ncia\%20_\%20Um\%20conceito\%20em\%20tr\%E2nsito\%20na\%20cena\%20bra sileira.pdf. Acesso em: 29 jan.2017. 